\title{
@(๑) $\Theta \Theta$
}

This work is licensed under a Creative Commons Attribution-NonCommercialNoDerivatives 4.0 International License. Fonte:

https://livros.unb.br/index.php/portal/catalog/book/94. Acesso em: 25 maio 2021.

\section{REFERÊNCIA}

GHIRALDELLI, Reginaldo (org.). Trabalho, direitos e desigualdades na realidade brasileira. Brasília: Editora Universidade de Brasília, 2021. 268 p. (Pesquisa, Inovação e Ousadia). Disponível em: https://livros.unb.br/index.php/portal/catalog/book/94. Acesso em: 25 maio 2021. 


\section{Trabalho, direitos e \\ desigualdades \\ na realidade \\ brasileira}

Reginaldo Ghiraldelli

(organizador)
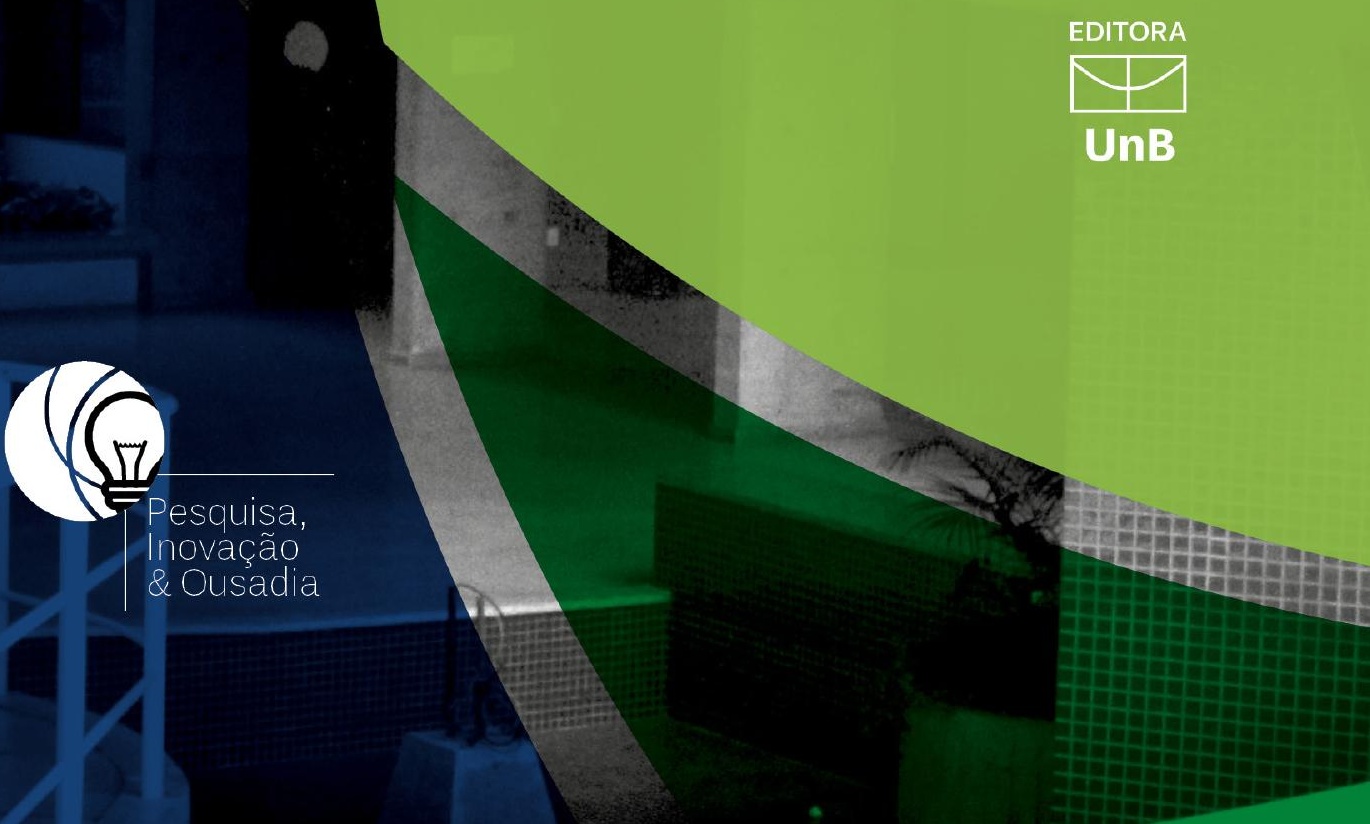


\section{$\Psi$ Universidade de Brasília}

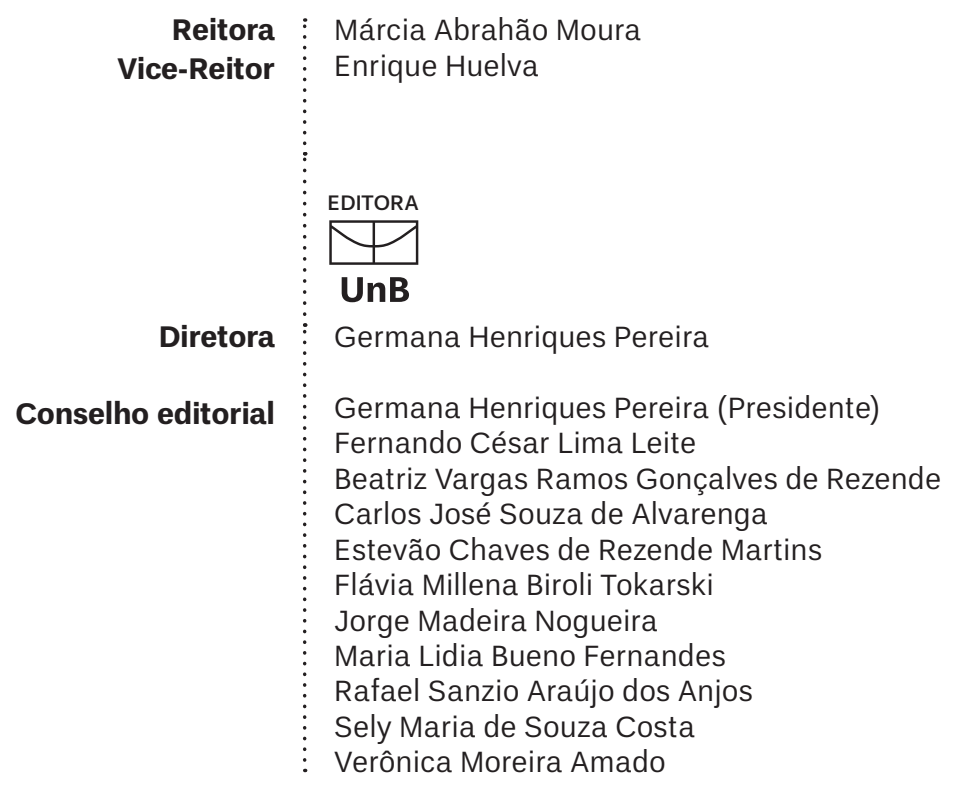




\section{EDITORA}

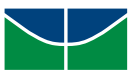

UnB

Trabalho, direitos e

desigualdades na realidade brasileira

Reginaldo Ghiraldelli (organizador)

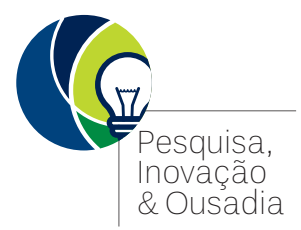




\section{Equipe editorial}

Coordenação de produção editorial

Preparação e revisão

Projeto gráfico

Diagramação
Luciana Lins Camello Galvão

Angela Gasperin Martinazzo

Wladimir de Andrade Oliveira

Haroldo Brito

(C) 2020 Editora Universidade de Brasília

Direitos exclusivos para esta edição:

Editora Universidade de Brasília

SCS, quadra 2, bloco $\mathrm{C}, \mathrm{n}^{\circ} 78$, edifício OK, $2^{\circ}$ andar, CEP 70302-907, Brasília, DF

Telefone: (61) 3035-4200

Site: www.editora.unb.br

E-mail: contatoeditora@unb.br

Todos os direitos reservados. Nenhuma parte desta publicação poderá ser armazenada ou reproduzida por qualquer meio sem a autorização por escrito da Editora.

Esta obra foi publicada com recursos provenientes do Edital DPI/DPG n³/2019.

1. Trabalho - Aspectos sociais. 2. Direitos sociais. 3. Política social. 4. Desigualdade social. I. Ghiraldelli, Reginaldo (org.). II. Série. 


\section{Sumário}

\section{Prefácio 9}

\section{Apresentação 17 \\ Reginaldo Ghiraldelli \\ Capítulo 1}

Trabalho, contrarreformas e (des)proteção social no Brasil 27

Reginaldo Ghiraldelli

Introdução 27

1. O Brasil nos tempos neoliberais e as mudanças nas relações de trabalho $\mathbf{3 2}$

2. A construção contraditória dos direitos sociais no Bra-

sil: crises, contrarreformas e retrocessos sociais $\mathbf{3 7}$

3. A Contrarreforma Trabalhista e a dilapidação dos direitos sociais 47

Considerações finais $\mathbf{5 2}$

Capítulo 2

Classe trabalhadora, novo sindicalismo e autoemancipação 61

Michelly Ferreira Monteiro Elias

Introdução 61

1. O avanço das lutas da classe trabalhadora no período de esgotamento da ditadura civil-militar e a formação do novo sindicalismo $\mathbf{6 4}$

2. O significado político do novo sindicalismo para as lutas da classe trabalhadora brasileira 73

3. O novo sindicalismo frente à perspectiva da autoemancipação da classe trabalhadora brasileira $\mathbf{7 8}$ Considerações finais $\mathbf{8 3}$ 
Capítulo 3

O trabalho temporário no Estado capitalista 87

Eduardo Augusto Rodrigues Barros

Introdução 87

1. O trabalho temporário no capitalismo $\mathbf{8 9}$

2. O trabalho temporário nos serviços privados e públicos no Brasil 91

3. O contrato temporário na carreira socioeducativa do

DF e sua precarização 96

Considerações finais $\mathbf{1 1 5}$

Capítulo 4

A participação social no campo da saúde do trabalhador e da trabalhadora 125

Natália Pereira Caixeta

Introdução 125

1. Precarização estrutural do trabalho e rebatimentos na organização da classe trabalhadora 127

2. Percurso teórico-metodológico e controle democrático no campo da saúde do(a) trabalhador(a) $\mathbf{1 3 0}$

3. A Política Nacional de Saúde do Trabalhador e da Trabalhadora (PNSTT) 149

Considerações finais $\mathbf{1 5 2}$

Capítulo 5

A Política Nacional de Educação Permanente do Sistema Único de Assistência Social 159

Renata Maria da Conceição Freitas

Introdução 159

1. Contextualização sócio-histórica da Política Nacional de Educação Permanente para Trabalhadores do Sistema Único de Assistência Social 163

2. A Institucionalização da Educação Permanente 177 Considerações finais 192 
Capítulo 6

\section{As multifaces do trabalho precário no Sistema Único de Assistência Social 201}

Regiane Cota e Rocha

Introdução 201

1. Considerações sobre as unidades dos Centros de Referência de Assistência Social (Cras) e dos Centros de Referência Especializado de Assistência Social (Creas) 208

2. Condições de trabalho no Suas sob a ótica dos trabaIhadores 211

Considerações finais $\mathbf{2 2 4}$

Capítulo 7

Ações profissionais e condições de trabalho de assistentes sociais na Atenção Primária à Saúde 231

Andreia de Oliveira

Reginaldo Ghiraldelli

Introdução 231

1. Serviço Social, Saúde e Atenção Primária à Saúde 239

2. O percurso metodológico-investigativo e a aproximação ao cotidiano de trabalho de assistentes sociais $\mathbf{2 4 3}$

Considerações finais $\mathbf{2 6 0}$

Sobre os autores e as autoras 265 


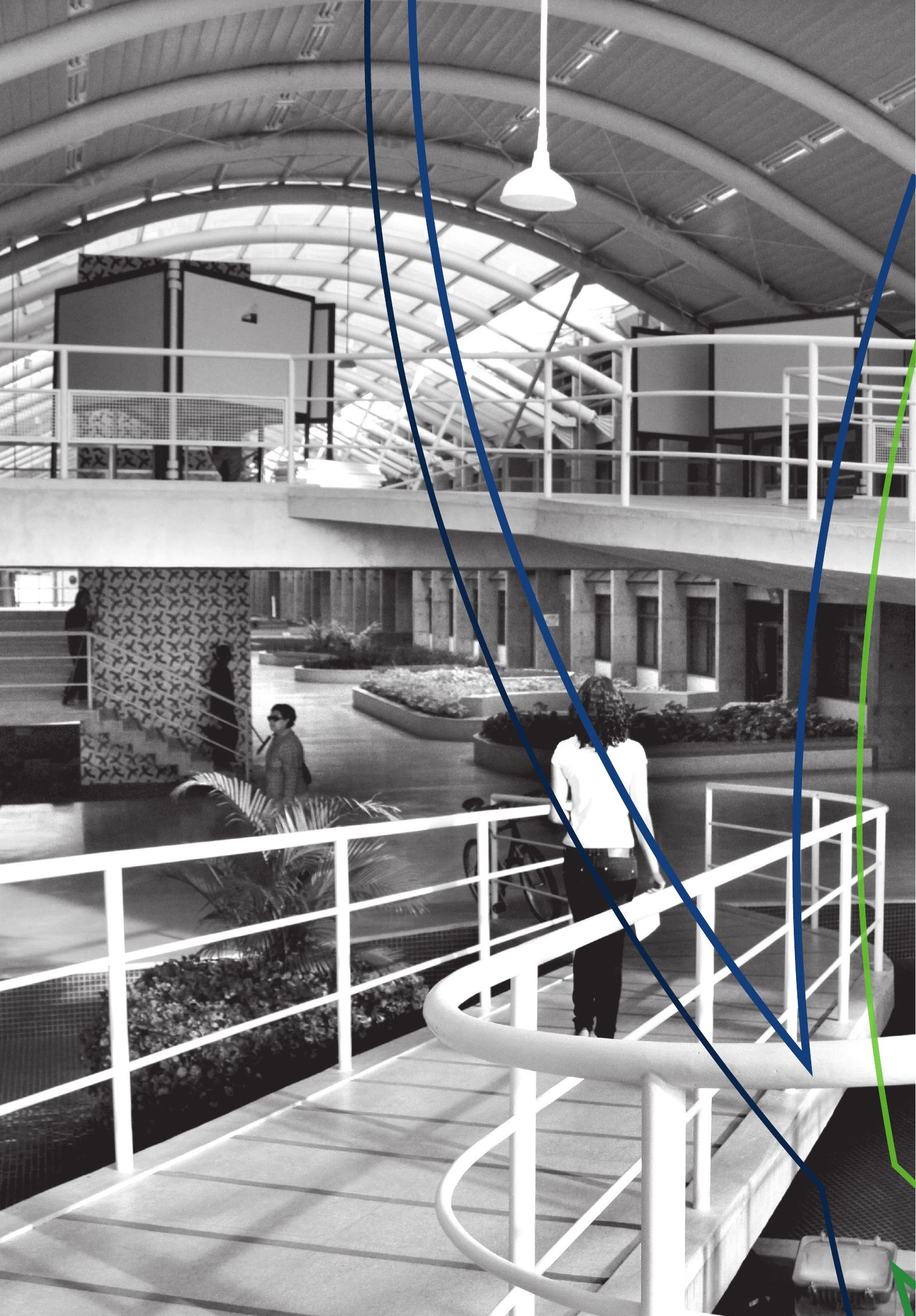




\section{Prefácio}

Por pelo menos três décadas, houve um debate sobre o futuro do trabalho no mundo. Embora essas abordagens tenham se dado de maneira vaga, ao mesmo tempo despertaram fascínio e extemporaneidade. Mas, afinal, de que trabalho tratam essas abordagens? Trabalho físico? Trabalho protegido? Trabalho como fonte de identidade? Trabalho como fonte de renda? Ou, ainda, outras formas de trabalho? Ao buscar entender esse debate, podemos pensar em dois tipos de "previsões”: uma que antevê um declínio qualitativo do trabalho, e a outra, um declínio quantitativo.

No primeiro caso, o do declínio qualitativo, o trabalho pioraria em suas condições (tornando-se instável e sem garantias) e em seu conteúdo (tornando-se mecânico e rotineiro). No segundo caso, o do declínio quantitativo, o trabalho se tornaria escasso, acima de tudo por causa da difusão de tecnologias que substituiriam o labor humano, e passaria por uma espécie de "mutação genética” - o que, com base em um processo histórico de individualização, transformaria o trabalho existente em trabalho por conta própria.

Nos dois casos, a mudança levaria a uma perda de significado e, portanto, da centralidade do trabalho na vida social. Esse trabalho modificado resultaria na perda de identidade e de sentido do - e no trabalho. E isso também afetaria a capacidade organizacional da classe trabalhadora, com consequências significativas para as formas coletivas de representação, como é o caso dos sindicatos. A ausência de uma 
potencialidade representativa dos trabalhadores poderia esvaziar esses espaços coletivos e trazer implicações para o sentido dessas organizações.

No entanto, seguir profecias não nos leva muito longe. Com efeito, existe o fato paradoxal de que, ao tentar "roubar" a tarefa dos futurologistas, a sociologia do trabalho quase parou de olhar para o seu entorno, ou seja, para a realidade social. Deixar fluir a imaginação a partir de uma prospecção virtual é inquestionavelmente menos exigente do que ir a campo coletar dados e oferecer retratos concretos do presente. Essa segunda opção é a que nos ancora, dando sustentação acadêmica e científica para a explicação do real, embora saibamos de suas limitações.

Para a compreensão dessas tendências em curso, algumas chaves heurísticas fornecem fundamentos para a interpretação da realidade, a exemplo do processo de complexificação e heterogeneidade do trabalho, que envolve o seu conteúdo (autonomia, controle), as condições físicas e a deterioração da qualidade do emprego diante de uma crescente instabilidade e congelamento salarial.

Na contemporaneidade, observa-se a transição de uma certa homogeneidade das condições de vida e de trabalho típicas de boa parte do século XX, tendo como referência o padrão fordista, para uma clara heterogeneidade e fragmentação do trabalho. Emergem também questões relacionadas à proteção social e à representação coletiva. Essa homogeneidade foi o fertilizante para o crescimento e a afirmação dos sindicatos, que, graças a condições políticas e históricas particulares, puderam se tornar instituições de massa no sentido das adesões e das estratégias adotadas. A heterogeneidade aponta atualmente para o problema da unidade coletiva da classe trabalhadora, tendo em vista o risco evidente de uma composição difícil e frágil, a partir das diferentes instâncias de representação dos trabalhadores. Mas quais são os fenômenos e as tendências que podemos evidenciar a partir dessa base? Primeiramente, é preciso examinar os problemas atuais, mas não apenas como eles se apresentam nos países centrais do capitalismo. Isso significa que é necessário um olhar global acerca desses processos em curso.

Assim, uma primeira consideração é a aproximação entre os diferentes grupos de países, cujas classificações são atualmente inspiradas 
em modelos baseados na ideia da "variedade de capitalismos". Nesse caso, é importante uma abordagem analítica e crítica, voltada aos mecanismos de difusão da precarização e da crescente dualização do mercado de trabalho, de forma a identificar questões do mundo do trabalho que acentuam os riscos e vulnerabilidades sociais. Temos modalidades diferentes e ao mesmo tempo coexistentes. Os dados revelam a disseminação de mini-empregos ou outros "meios de trabalho”, com horários curtos, salários baixos e proteção social extremamente reduzida.

A segunda consideração é que, diante das mudanças em curso, está aumentando, entre os trabalhadores, um sentimento de insegurança em relação ao presente e de incerteza quanto ao futuro. Esse sentimento é transversal, mas atinge especialmente os segmentos mais vulneráveis da classe trabalhadora, ou seja, aqueles com menor qualificação profissional e com inserções/posições ocupacionais de menor "status" e prestígio na divisão do trabalho. Esses segmentos de trabalhadores também estão se distanciando de forma acentuada das tradicionais representações políticas pró-trabalho, como é o caso dos sindicatos.

A terceira consideração diz respeito aos aspectos e efeitos sociológicos mais típicos dessas transformações. De fato, observamos uma sociedade desestruturada e muito estratificada, na qual os trabalhadores não encontram uma identidade comum e um projeto compartilhado. Estamos diante da difusão de um sujeito incerto e disforme em relação à tradicional "classe operária” ou outras formas unificantes da classe trabalhadora. Uma espécie de “quinto Estado”, em que prevalece como característica a precariedade. Ao mesmo tempo, notamos a falta de um amálgama que se dê a partir dos “de baixo”, ou seja, os mais subalternizados, que diz respeito a um grande contingente de pessoas que trabalham, além da premissa de mecanismos de agregação e construção de identidades coletivas pela via das representações coletivas.

No debate científico, há uma tendência a dizer que, na maioria dos países ocidentais (mas também frequentemente naqueles emergentes), as organizações representativas - estamos falando especificamente dos sindicatos - enfraqueceram com o tempo, algo que pode ser deduzido da análise de dados sobre sindicalização e sobre os rumos de seu poder 
de barganha, capilaridade e pressão. Mas, em geral, muitos estudos analisam o poder decrescente dos sindicatos como resultado de "erros" de suas escolhas estratégicas, tendo como base a herança de períodos anteriores, mais frutíferos. Essas abordagens deveriam ser revisitadas. Vale ressaltar, no entanto, que muitas vezes é a fragilidade e decomposição do mercado de trabalho - a instabilidade de muitos trabalhadores, o crescimento do trabalho precário, a redução de direitos sociais - que atinge a capacidade organizativa dos sindicatos.

Podemos citar, como ilustração, alguns dados da realidade italiana. Informações dos sindicatos confederais (CGIL, CISL e UIL) ${ }^{1}$ são relativamente estáveis e contínuas, e insistem em apresentar um notável acordo social e organizacional. Mas, sob a pátina e a superfície dessa aparente continuidade, surge uma mudança também significativa nas demandas e expectativas dos trabalhadores, que coincide com o quadro de incerteza e insegurança social.

As demandas e necessidades dos trabalhadores também mudaram no decorrer dos anos. O descompasso é ainda mais intenso em comparação com resultados de pesquisas realizadas nos primeiros anos deste século. O item claramente privilegiado era o da grande tradição da unidade sindical. Nesse caso, como podemos interpretar essas interessantes descontinuidades presentes na realidade? Também nesse contexto, podemos observar os sinais da grande crise pós-2008 e as crescentes inseguranças resultantes desse processo.

As reivindicações e expectativas expressas pelos trabalhadores parecem defensivas, marcadas pela necessidade de não perder seus postos de trabalho (que consideram ameaçados) diante da crescente instabilidade laboral. Para além de um sindicalismo projetado no sentido de grandes batalhas ideais e políticas, generalista e orientado para o cultivo de interesses amplos, parece que essas questões estão sendo reduzidas e deslocadas para outras direções, mais iminentes e ligadas à satisfação de interesses imediatistas, mais preocupadas com a gestão

1 CGIL: Confederação Geral Italiana do Trabalho; CISL: Confederação Italiana de Sindicatos e Trabalhadores; UIL: União Italiana do Trabalho. 
de crises e reestruturações corporativas e, portanto, com a capacidade de os sindicatos assumirem a transição para uma fase "normalizada" da vida produtiva. O que tende a prevalecer nessa conjuntura é a ideia de um sindicato que intervenha nas demandas imediatas dos trabalhadores, de forma também a tranquilizá-los diante das ameaças postas.

Também como efeito de identidades coletivas alteradas em um processo de mudança geracional, não é por acidente que a questão da unidade sindical - no passado, de forte valor simbólico - seja pouco considerada pelos mais jovens.

As mudanças em curso são ainda menos lineares e mais incertas do que se imaginava. A instabilidade no emprego cresce de forma exponencial e irregular, não apenas em função da grande variedade de formas contratuais, mas também devido ao aumento, muitas vezes discricionário, das horas de trabalho.

Dentre os exemplos usados para ilustrar tais fenômenos, podemos mencionar a "revolução digital”, que já produziu, além de intensas mudanças na organização da produção, uma grande quantidade de estudos e publicações científicas. Não faltam entusiastas dessas mudanças em andamento, que são descritas como incontornáveis e, ao mesmo tempo, cada vez mais problemáticas para o trabalho, diante da escassez da geração de postos laborais. Com isso, emerge a ideia da "quarta revolução científica” como uma grande oportunidade para repensar o modelo de desenvolvimento econômico e social dos países, uma visão que atribui às tecnologias o papel de Leviatã do mundo contemporâneo, mas, ao mesmo tempo, é medida com uma instância - a da "regulação" - tornada incerta pela evanescência dos atores sociais e pelas políticas adotadas.

Precisamente por esse motivo, permanecem muitas incertezas sobre as trajetórias e os resultados das inovações em curso, seja por causa das muitas variáveis que pesam sobre os efeitos técnicos e organizacionais "internos” da esfera produtiva, seja pela dificuldade de dar conta dos efeitos da propagação “externa”. Em outras palavras, não se contempla o potencial dos atores coletivos de forma a pensar as prováveis consequências sociais dessas transformações, sobretudo nas condições de vida e trabalho. 
Como são feitas muitas previsões, em particular sobre o número e a qualidade dos empregos disponíveis, em geral prevalecem as estimativas pessimistas, suavizadas por alguns relatórios institucionais, que tendem a descrever uma redução quantitativa e uma polarização qualitativa no mercado de trabalho como cenários mais plausíveis. De modo recorrente e sucessivo, todas as "grandes transformações" têm impactado diretamente a vida da classe trabalhadora. E essa vinculação à digitalização e o advento da Gig Economy ${ }^{2}$ não serão exceções. Trata-se, no entanto, de entender se existem margens - como aconteceu no passado - para identificar alavancas regulatórias e outras possibilidades coletivas que enfrentem os efeitos sociais dessa realidade.

Quando pensamos nos atores sociais, temos naturalmente em mente os atores clássicos, institucionais e sociais, que impactaram sobre a regulamentação do trabalho, mesmo que não possamos excluir outros, alguns dos quais são novos. Por um lado, têm-se os espaços potenciais à disposição das instituições públicas. Eles são vistos, com relação à disseminação da digitalização, principalmente como portadores de incentivos e ajuda econômica. Mas grande parte das implicações futuras também dependerá da amplitude de seu intervencionismo (e aqui falamos do âmbito nacional, mas devemos falar mais dos contextos supranacionais). No caso de uma intervenção geral, serão abordadas as consequências sociais e econômicas do novo paradigma, ou a atuação se limitará a uma tarefa meramente acessória de apoio ao mercado (espelhando, portanto, a existente)?

Por fim, outra questão, não secundária, envolve a trama dos direitos e proteção social de trabalhadores com perfis amplos e evanescentes, diferentes dos modelos "tradicionais" que herdamos de períodos anteriores. Diante disso, que tipo de inclusão pode ser proposta aos

2 No contexto das mudanças no mundo do trabalho e do desmonte dos direitos sociais, a Gig Economy representa o aprofundamento da precarização e intensificação do labor por meio de formas contratuais flexíveis, temporárias, sem proteção e garantias sociais, especialmente mediante o crescimento das ocupações denominadas "bicos" e os conhecidos contratos freelancer. São formas contratuais em expansão, sobretudo com o crescimento da ocupação em serviços por meio das plataformas digitais. 
trabalhadores “digitais”, os quais são - como se costuma dizer em estudos comparativos - "não empregados”?

Nessa agenda, existem espaços de ação anteriores às tomadas de decisão, tanto aqueles relacionados à introdução de novas tecnologias quanto os que traduzem novas configurações tecnológicas em estruturas organizacionais. Agora, o ponto crítico do nosso sistema de produção está precisamente conectado à lacuna a ser coberta entre essas duas dimensões. Muitas empresas fazem investimentos em novas tecnologias, mas não se comprometem com um redesenho organizacional e muito menos com suas consequências sociais para os trabalhadores.

As instituições públicas poderiam promover e incentivar métodos participativos de mudança organizacional, em vez de focalizar apenas o aumento de equipamentos tecnológicos.

Por isso, devemos pensar em formas de regulação diante da reorganização das empresas em um contexto de incorporação e expansão das tecnologias digitais. Aqui é necessário pensar novas formas de contratação, além de fortalecer os canais de participação dos trabalhadores. Isso abrange novas políticas (incluindo redução de jornada e trabalho inteligente) e profissionalismo, além da difusão de medidas de bem-estar social, especialmente para segmentos mais desfavorecidos e subalternizados da força de trabalho.

As instituições podem contribuir para a efetivação da cidadania no trabalho por meio do acesso a direitos e proteções. Não apenas direitos genéricos, os quais também são necessários, mas espaços contratuais reconhecidos e salários mínimos garantidos, por exemplo.

Por fim, cabe destacar a importância das políticas públicas nacionais, com ênfase na expansão das políticas de trabalho, tendo em vista que o cenário atual é marcado pelo medo do desemprego em massa. Esse temor também deve ser atenuado, no nível social, com intervenções públicas destinadas a reduzir as crescentes inseguranças. Muitos consideram a renda básica de cidadania como uma opção plausível e necessária. Certamente essas intervenções “passivas” são essenciais, sobretudo com a finalidade de manter os padrões mínimos de vida e as necessidades básicas da população. 
A transição para uma nova estrutura de produção também exige claramente uma mudança semelhante - possivelmente contextual - do sistema institucional e da regulação social. Eis a grande virtude a ser redescoberta e retrabalhada em busca da construção de novas bases. Esse é o desafio para as instituições e os atores sociais. Nas últimas décadas, o capitalismo democrático e tradicionalmente moderado deixou gradualmente de lado suas virtudes sociais. E hoje, tanto na Europa quanto na América Latina (para não mencionar os Estados Unidos), é necessário um novo arranjo, um novo horizonte, uma nova base. Isso significa pensar e incluir um novo "compromisso histórico" capaz de conter e afirmar os direitos sociais. Esse objetivo não parece estar imediatamente ao alcance, mas, precisamente por esse motivo, deve ser introduzido por meio de análises científicas e propostas políticas.

O mundo do trabalho, hoje, é caracterizado pela disseminação de novas problemáticas e novas inseguranças. Pouca ênfase é dada aos processos de perda qualitativa do trabalho, à crescente precarização, à redução das proteções sociais que estão trazendo à tona o trabalho empobrecido e propenso a riscos de exclusão - processos estes que estão sendo difundidos e implementados de modo generalizado pelo mundo.

Nesse sentido, eis a importância do compromisso intelectual na direção de um melhor entendimento e aprofundamento da realidade social, tanto de sua natureza qualitativa quanto de sua natureza quantitativa. Cabe aos intelectuais e pesquisadores compreender esses processos sociais com suas devidas implicações e apontar possíveis alternativas e saídas. Mas sabemos que as possíveis saídas e superações dependerão da capacidade organizativa dos atores sociais (velhos e novos, sociais e institucionais), com o objetivo de constituir novos pactos sociais e compromissos políticos. Isso significa tomar como referência as demandas, interesses e necessidades dos trabalhadores. ${ }^{3}$

Mimmo Carrieri Universidade de Roma "La Sapienza”

3 Texto originalmente redigido em italiano e traduzido para a língua portuguesa por Reginaldo Ghiraldelli. 


\section{Apresentação}

Reginaldo Ghiraldelli

(Organizador)

Analisar a atual configuração do mundo do trabalho e dos direitos sociais no Brasil, seguindo o rigor acadêmico e científico, não é uma tarefa fácil e simples. Isso porque nos deparamos no tempo presente com movimentos que negam, rechaçam e criminalizam o conhecimento científico, crítico e criterioso da realidade social. São tempos obtusos, de ameaças e ataques à educação pública e à autonomia e sustentabilidade da universidade pública, como também de censura ao pensamento crítico. Essa realidade requer, de intelectuais e pesquisadores das diversas áreas do conhecimento, capacidade analítica que possibilite o trânsito e a ultrapassagem entre a aparência fenomênica e a essência da vida social, de modo a extrapolar o obscurantismo que paira na cena cotidiana e contemporânea. Isso só é possível por meio de apreensões consistentes da realidade e concepções teóricas e empíricas fundamentadas no trato rigoroso da pesquisa acadêmico-científica.

O Brasil, nos últimos anos, atravessa uma crise caracterizada, sobretudo, por instabilidades econômicas, crescimento das desigualdades sociais e polarização ideopolítica da sociedade. Esse cenário traz em si 
as marcas contraditórias, tensas e conflituosas da formação social brasileira. País de dimensão continental, de reconhecidas riquezas culturais e naturais, mas também de profundas desigualdades sociais e elevada concentração de renda, o Brasil preserva traços de uma história que se sustentou no escravismo mercantil, em relações de exploração-opressão e na constituição de uma classe dominante individualista, preconceituosa, racista, patriarcal, violenta, sanguinária, avessa ao bem-estar coletivo e aos direitos de cidadania.

Por isso, é importante apreender a processualidade histórica na análise da realidade brasileira, sobretudo com o agravamento da crise econômica e política que ameaça os pilares da democracia e dos direitos sociais, constituídos, nas últimas décadas, por meio de árduas lutas da classe trabalhadora.

Essa crise contemporânea apresenta proporções e dimensões que envolvem toda a estrutura do sistema capitalista, mas com traços novos e processos inéditos. Ocorre nessa fase um redimensionamento do Estado, que, mantendo seu caráter autoritário e de classe, sob os preceitos neoliberais, passa a adotar medidas de austeridade, ajuste fiscal, privatizações e cortes nas políticas públicas. Nesse novo ordenamento, são implementadas medidas de enxugamento da regulação estatal, que resultam no ataque medular ao sistema de proteção social e na liquidação dos direitos de cidadania, por meio de privatizações e apropriação do patrimônio e do fundo público para fins mercantis.

Nos marcos dessa crise, em que responsabilidades do Estado são transferidas para a sociedade, são formulados mecanismos ideopolíticos de crítica ao "Estado Social”, como se o intervencionismo estatal na esfera social fosse um obstáculo para o desenvolvimento econômico e para o pleno exercício da liberdade, da democracia e da cidadania. São formulações falaciosas, e o que se observa, diante das façanhas do capital financeiro e das medidas neoliberais regressivas implementadas nas últimas décadas, é um quadro de barbárie civilizatória, que se expressa no aprofundamento das desigualdades sociais, no desemprego em dimensão estrutural, nos crimes ambientais, na xenofobia, no racismo, no machismo, na LGBTfobia, na criminalização da pobreza, 
na repressão às lutas sociais e no ataque às liberdades democráticas, dentre outras evidências que encontram respaldo nas formas violentas de exploração e opressão da sociedade capitalista-patriarcal-racista.

Diante do aprofundamento de medidas neoliberais, a máxima (compreendida como regra) do intervencionismo do Estado, no estágio de acumulação do capitalismo financeiro-internacional, passa a ser a desregulamentação dos direitos de cidadania, a apropriação do fundo público para fins mercantis e a privatização do patrimônio e dos serviços públicos. A reorientação da política social como atividade não exclusiva do Estado potencializa sua mercantilização, que passa a ser tratada como negócio rentável e lucrativo, como se observa com as medidas de privatização da saúde, da educação e da previdência. Economicamente, o neoliberalismo busca atacar e minar tudo o que diz respeito às políticas públicas e aos direitos sociais, enquanto no plano ideopolítico, por meio de mecanismos geradores de consensos, busca introduzir a ideia do esforço, do mérito e da capacidade individual, transferindo para os indivíduos responsabilidades amparadas em uma lógica perversa de "premiações” pelos "sucessos" em detrimento da culpabilização e penalização pelos "fracassos" e "derrotas” individuais. Assim, a ideia de sucesso e fracasso passa a compor o universo da sociabilidade capitalista de orientação neoliberal, evidenciando os valores do individualismo e da meritocracia.

A promulgação da Constituição Federal de 1988, resultado de interesses, disputas e forças divergentes, é um importante marco na edificação da proteção social brasileira, diante do reconhecimento da seguridade social como direito de cidadania e dever do Estado. A seguridade social contempla as políticas públicas de saúde (reconhecida como direito universal, independente de contribuição), a assistência social (para quem dela necessitar, mediante critérios de seletividade) e a previdência social, de caráter contributivo.

O texto constitucional também apresenta, em seu artigo $6^{\circ}$, o trabalho como um direito social fundamental, e no artigo $7^{\circ}$, elenca detalhadamente o que contemplam esses direitos. Contudo, os anos 1990 são marcados pela implantação de medidas neoliberais no Brasil, sob 
a orientação do Consenso de Washington de 1989, o que significou os limites de efetivação das prerrogativas contidas na carta constitucional.

Em 1993, é aprovada no Tribunal Superior do Trabalho (TST) a súmula $\mathrm{n}^{\circ} 331$, que descrevia e autorizava a terceirização das atividades-meio. A partir de então, ainda nessa década, iniciou-se um amplo e forte processo de flexibilização e precarização das relações de trabalho, que processual e gradativamente foi derruindo os direitos previstos na Consolidação das Leis do Trabalho (CLT). Seu desmonte em sentido pleno aconteceu em 2017, com a aprovação da Reforma Trabalhista, durante o governo de Michel Temer.

Teses de conteúdo liberal estão na base dos grupos defensores da Reforma Trabalhista, na medida em que julgam a CLT obsoleta, apontam para a necessidade de um mercado autorregulado e consideram que a proteção social é uma limitação e ameaça para o crescimento econômico, a competitividade e a geração de empregos. São teses falaciosas, pois o que se observa é um acirramento da crise política e econômica no Brasil, com implicações para o crescimento das desigualdades sociais e regionais. Dados recentes sobre o elevado índice de desemprego no país, após a vigência da nova legislação trabalhista, revelam os ardis contidos no discurso da "modernização” trabalhista como receituário para a geração de empregos.

A nova legislação trabalhista abre caminho para a desproteção total e absoluta de trabalhadores e trabalhadoras, colaborando para o desmonte dos direitos sociais, para os processos de intensificação, precarização, terceirização e subcontratação e para o aumento de acidentes e adoecimentos advindos da sobrecarga laboral, além da fragmentação da classe trabalhadora, tendo em vista os entraves para a organização sindical.

O que se observa, nesse contexto de crise e de acirramento das lutas de classe, é um movimento do capital que, para assegurar interesses e necessidades sob a ótica lucrativa, reprodutiva e acumulativa, impõe medidas draconianas que atingem visceralmente o conjunto da classe trabalhadora, como é o caso da citada Reforma Trabalhista, que traz consequências diretas para a degradação do trabalho e para a vida da população que vive e sobrevive do trabalho. Ações predatórias 
e destrutivas estão em curso, sob a chancela e orquestração do capitalismo financeiro, tendo como base a defesa intransigente de mudanças na legislação, com o objetivo de desestruturar o sistema de proteção social e de direitos da classe trabalhadora. Também nesse contexto de retrocessos humanos e sociais sem precedentes, vem à tona a exaltação da tortura, a defesa da liberação do porte de armas, a criminalização e censura ao pensamento crítico, a apologia à violência e a recusa aos debates sobre questões de gênero e diversidade sexual.

As reformas apresentadas, como a Trabalhista e a da Previdência, soam como o "canto da sereia”, no sentido de construir um arcabouço ideopolítico para ludibriar, seduzir e convencer a população de que tais medidas são necessárias para atacar e eliminar os privilégios existentes, de modo a resolver os inúmeros e históricos problemas sociais brasileiros. Porém, o que se verifica, considerando a face autoritária do Estado, são ataques e punições aos pobres e aos trabalhadores brasileiros diante das perdas de direitos conquistados historicamente. O que está em curso é um processo gradativo de desmonte da nação e de destruição dos frágeis alicerces de um Estado Social constituído nas últimas décadas com base em valores e princípios democráticos.

O pacto constitucional dos anos 1980 materializou o compromisso do Estado brasileiro com a cidadania, a dignidade humana, a justiça, a liberdade, a democracia, os direitos sociais e o combate ao preconceito e à discriminação. Por isso, analisar a edificação dos pilares democráticos e de direitos requer uma interpretação dialética da Carta Magna de 1988, de forma a considerar os interesses antagônicos, as contradições, as disputas e as forças em presença, tendo em vista a afirmação da cidadania, da democracia, da justiça e ao mesmo tempo a sua negação, pois o que se observa é uma sequência de medidas contrárias e autoritárias que caminham para a desconstrução da proteção social.

Na contramão dos valores e princípios democráticos, o Brasil vive uma onda de retrocessos diante de uma forte ofensiva conservadora, reacionária e ultraliberal, que afeta e desmantela a proteção social e os direitos conquistados historicamente por meio de lutas e resistências da classe trabalhadora. São tempos de retrocessos históricos, de barbárie, 
de destruição dos direitos e também de consequências danosas e irreversíveis para o meio ambiente, colocando em risco o futuro e a reprodução da humanidade.

O atual estágio de sociabilidade capitalista, baseado em uma exploração sem limites e sem precedentes na história, abre as portas para a instauração da barbárie. Tal projeto, fundamentado na inversão de valores e em uma sociedade coisificada, ameaça a condição existencial de vida e sobrevivência humana. Os indivíduos sociais se deparam com o limite da sobrevivência e com a ausência de sentido no que se refere à própria existência, diante da mercadorização e fetichização da vida social. Nesse espectro, sob a ótica predatória do capital, os indivíduos sociais são vistos meramente como fonte de lucro e acumulação capitalista.

O desmonte do "Estado Social”, prevê a maximização da exploração humana nos processos de produção e a redução da classe trabalhadora ao nível de coisa. As condições humanas de cidadania e de dignidade são negadas e formas de exploração e opressão são potencializadas, com repercussões na cena pública, como é o caso do trabalho análogo ao escravo, humilhações, assédios, violência, crimes de ódio, dentre outros exemplos de violação de direitos que expõem os custos humanos de uma crise civilizatória que se alastra internacionalmente desde os anos 1970 e se intensifica atualmente.

No Brasil de desigualdades históricas e profundas, assentadas na exploração, na opressão, no patriarcado, no racismo e na intolerância à diversidade humana, o presente livro/coletânea é um convite a pensar criticamente os rumos do trabalho e da proteção social diante da dilapidação e aniquilamento de direitos e das ameaças aos pilares da democracia. Também se apresenta como um instrumento de resistência coletiva que caminha na contramão do obscurantismo e da negação do conhecimento acadêmico e científico. Por isso, é importante que tenhamos em mente os projetos de sociedade em disputa para que possamos lutar e defender, de forma consciente e crítica, um projeto societário que esteja comprometido com as necessidades da classe trabalhadora, no horizonte de uma sociabilidade humanamente emancipada. 
O livro/coletânea resulta de pesquisas realizadas nos últimos anos e vinculadas ao Grupo de Estudos e Pesquisas sobre Trabalho, Sociabilidade e Serviço Social (Trasso), do Departamento de Serviço Social e Programa de Pós-Graduação em Política Social da Universidade de Brasília (UnB). São resultados de pesquisas de docentes e de discentes que contaram com financiamento de agências nacionais de fomento como a Capes e o CNPq.

O tema da coletânea "Trabalho, direitos e desigualdades na realidade brasileira” é atual e interdisciplinar, e considera, pelos conteúdos abordados, a necessidade dos debates que constam na agenda política, social e econômica brasileira, tais como: a reforma trabalhista, os direitos e a proteção social; a organização e representação sindical; as diversas formas de contratação laboral, como é o caso do trabalho temporário no serviço público; a construção da política nacional de saúde do trabalhador e da trabalhadora; a importância e necessidade de uma política nacional de educação permanente para trabalhadores, além da discussão sobre as condições de trabalho nos diversos âmbitos da prestação de serviços sociais e públicos, como é o caso da saúde e da assistência social.

Na esteira das particularidades da realidade brasileira e considerando as transformações e tensões nas relações Estado-sociedade, a presente coletânea, organizada em 7 (sete) capítulos que dialogam com a atualidade do mundo do trabalho e dos direitos sociais, objetiva contribuir com o debate coletivo e com a produção de conhecimento.

O primeiro capítulo, “Trabalho, contrarreformas e (des)proteção social no Brasil”, apresenta, em linhas gerais, um breve panorama da constituição do mercado de trabalho e do sistema de proteção social brasileiro no decorrer do século XX, com o objetivo de compreender, a partir de uma perspectiva histórica e dialética, a construção dos direitos e o atual estágio de implementação de medidas de austeridade e contrarreformas voltadas para a destruição desses direitos. Também enfatiza as consequências deletérias da Contrarreforma Trabalhista para o conjunto da classe trabalhadora brasileira. 
O segundo capítulo, "Classe trabalhadora, novo sindicalismo e autoemancipação”, contextualiza a luta de classes no Brasil e o protagonismo do novo sindicalismo na segunda metade do século XX como importante movimento de organização e representação da classe trabalhadora na luta por direitos e emancipação. Discorre sobre os desafios postos ao movimento sindical em vista das características e particularidades da formação social brasileira, considerando as contradições, os limites e potencialidades para um processo de autoemancipação da classe trabalhadora.

No terceiro capítulo, o debate se volta para "O trabalho temporário no Estado capitalista”, tendo como ponto de partida as transformações recentes ocorridas no mundo do trabalho. Nele se analisa como a modalidade de trabalho temporário adentra todos os espaços, organizações e setores produtivos, como é o caso do serviço público. O texto apresenta reflexões sobre as características do trabalho temporário e aborda sua incidência e respectivos desdobramentos na realidade do serviço público do Distrito Federal, a partir de aproximações ao universo das políticas sociais socioeducativas.

O quarto capítulo resulta de pesquisa sobre “A participação social no campo da saúde do trabalhador e da trabalhadora”, que objetivou identificar os mecanismos de controle democrático e a efetivação dos direitos sociais a partir da experiência representativa e participativa de sujeitos políticos nas Conferências Nacionais de Saúde do(a) Trabalhador(a).

O quinto capítulo, intitulado "A Política Nacional de Educação Permanente para trabalhadores do Sistema Único de Assistência Social”, propõe-se a analisar os percalços na implementação dessa política, sob a ótica da garantia de direitos em um contexto de precarização estrutural das condições de trabalho e de sucateamento dos serviços sociais públicos. Nesse cenário de desmonte das políticas públicas e dos direitos sociais, o texto aborda os limites, as possibilidades e as perspectivas de efetivação da política de educação permanente como um direito de trabalhadores e trabalhadoras inseridos na prestação de serviços socioassistenciais. 
No sexto capítulo, “As multifaces do trabalho precário no Sistema Único de Assistência Social”, analisam-se as condições de trabalho de trabalhadores e trabalhadoras desse sistema, partindo da compreensão de que alterações substantivas e corrosivas ocorreram no mundo do trabalho e na relação Estado-sociedade, deteriorando as condições de vida e trabalho da classe trabalhadora, com repercussões nos espaços produtivos e reprodutivos. Além disso, cortes orçamentários nas políticas públicas atingiram sobremaneira a assistência social, provocando efeitos diretos na qualidade dos serviços prestados à população e, ao mesmo tempo, intensificaram e precarizaram as relações laborais.

O sétimo e último capítulo, "Ações profissionais e condições de trabalho de assistentes sociais na Atenção Primária à Saúde”, tem o propósito de apresentar, em linhas gerais, como se organizam os processos de trabalho de assistentes sociais nessa esfera de saúde, tendo como universo investigativo o Distrito Federal. A partir do recente redimensionamento do mercado de trabalho e das políticas sociais, são abordadas as ações profissionais, as atribuições, as competências e as condições de trabalho de assistentes sociais na área da saúde.

Por fim, desejamos uma boa leitura, na expectativa de que os anseios por uma forma de sociabilidade livre, igualitária e plena de sentidos alimentem os nossos horizontes. 


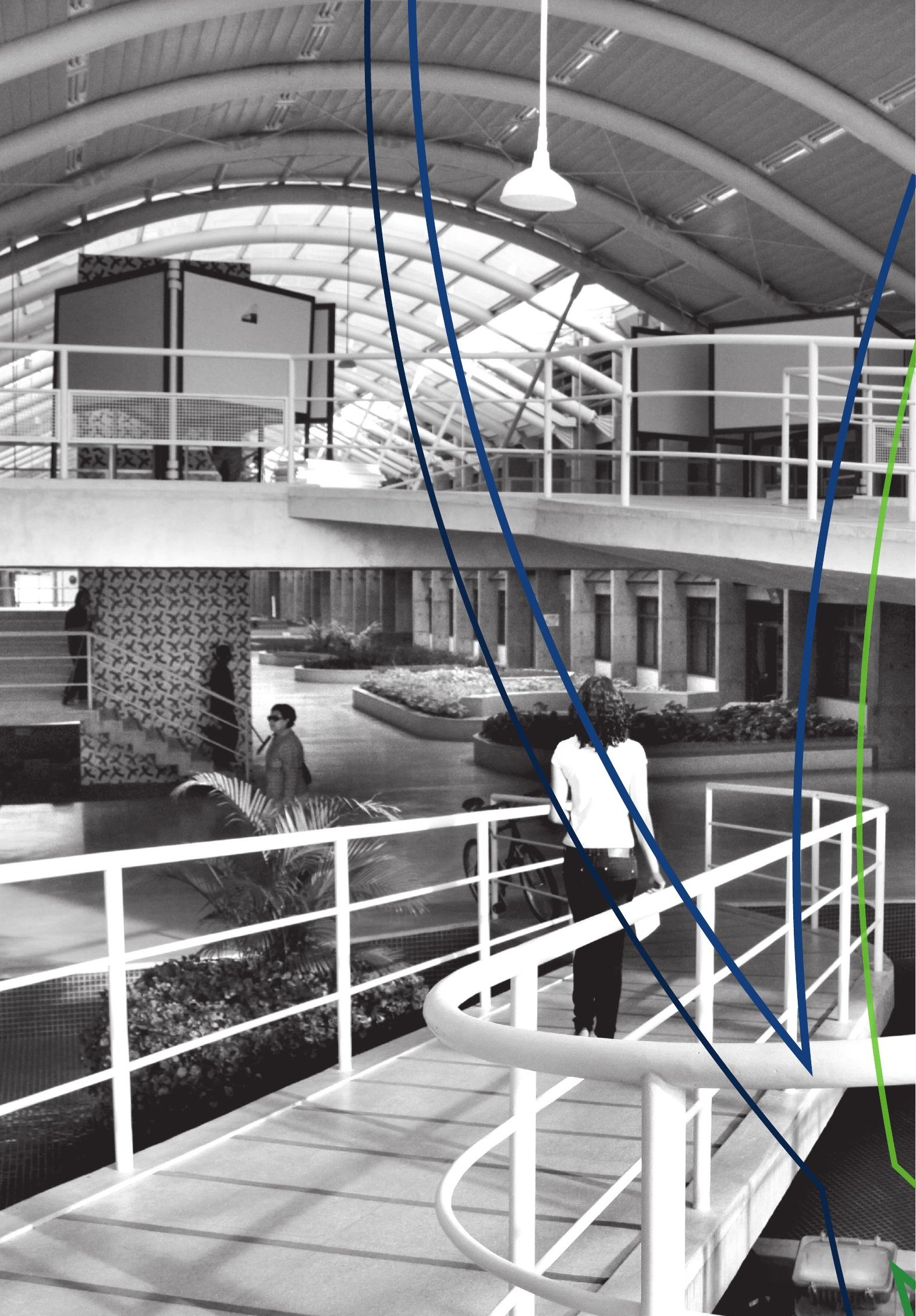




\section{Capítulo 1
Trabalho, contrarreformas e (des)proteção social no Brasil}

Reginaldo Ghiraldelli

Universidade de Brasília (UnB)

rghiraldelli@unb.br

\section{Introdução}

O presente texto aborda o redimensionamento do trabalho e o reposicionamento dos direitos e da proteção social diante dos acontecimentos recentes da conjuntura brasileira, que, sob o efeito de uma agenda regressiva e enérgica de austeridade e ajuste fiscal, incidem de forma direta e corrosiva na dinâmica do mundo do trabalho e na vida social.

Historicamente, no Brasil, o mundo do trabalho, considerando suas características, relações e condições laborais, passa por transformações 
significativas, desde as fases marcadas pela colonização portuguesa e a independência (1822) - período baseado na exploração do trabalho escravo -, pela proclamação da República (1889) e pelo intenso fluxo imigratório no final do século XIX e início do século XX, até a atualidade.

Mesmo após o fim da escravidão, em 1888, a economia brasileira permaneceu basicamente agrário-exportadora, com destaque para a produção e comercialização do café, que atravessou um período de desaceleração a partir dos efeitos da crise econômica mundial de 1929, sendo que até o início do século XX os direitos sociais e trabalhistas eram inexistentes. Entre os anos de 1930 e 1970, ocorre na sociedade brasileira um processo expansivo de urbanização e de industrialização tardia, alterando a configuração e a dinâmica do mercado de trabalho do país. Também nesse período se inicia um processo de regulação e estruturação do mercado de trabalho brasileiro e são constituídos, ainda que de forma limitada, os direitos sociais e trabalhistas.

Em relação aos direitos e à proteção social no Brasil, pode-se dizer que as primeiras medidas nesse sentido começam durante o governo de Arthur Bernardes, com a Lei Elói Chaves (Decreto n 4.682, de 24 de janeiro de 1923), que cria as Caixas de Aposentadoria e Pensão (CAPs) para trabalhadores do setor ferroviário, consideradas o embrião da previdência social brasileira. Em seguida, com a Lei no 5.109, de 20 de dezembro de 1926, o sistema é ampliado ao contemplar trabalhadores dos setores marítimo e portuário.

A partir de 1933, sob o governo de Getúlio Vargas (1930-1945), as CAPs passam a ser reunidas em Institutos de Aposentadoria e Pensão (IAPs), organizados pelo Estado, com abrangência nacional e ampliação da cobertura de segurados. A Constituição Federal de 1934 instituiu a tríplice forma de custeio, envolvendo governo, empregadores e empregados e, pela primeira vez, a Constituição de 1937 apresentou a expressão "seguro social”. A criação do Instituto Nacional de Previdência Social (INPS), ${ }^{1}$ pelo Decreto n ${ }^{0}$ 72, de 1966, significou a unificação

1 Em 27 de junho de 1990, por meio do Decreto nº 99.350, o órgão passou a ser denominado Instituto Nacional do Seguro Social (INSS), a partir da fusão do Instituto de Administração Financeira da Previdência e Assistência Social (Iapas) com o Instituto Nacional de Previdência Social (INPS). 
dos IAPs e a consolidação da previdência no país, porém ainda com limites, tendo em vista a exclusão de trabalhadores rurais e domésticos do sistema. ${ }^{2}$ Os trabalhadores rurais passaram a ser contemplados e incorporados ao sistema previdenciário com a Lei Complementar $\mathrm{n}^{\circ} 11$, de 25 de maio de 1971, que criou o Programa de Assistência ao Trabalhador Rural (Prorural), cabendo sua execução ao Fundo de Assistência ao Trabalhador Rural (Funrural). Sobre o trabalho doméstico, a Lei $n^{0} 5.859$, de 11 de dezembro de $1972,{ }^{3}$ regulamentada pelo Decreto $n^{\circ} 71.885$, de 9 de março de 1973, passou a assegurar benefícios e serviços previstos na Lei Orgânica da Previdência Social (Lei nº 3.807, de 26 de agosto de 1960) aos empregados domésticos. ${ }^{4}$

Outro marco desse período da história brasileira foi a Consolidação das Leis do Trabalho, conhecida como CLT - Decreto-Lei n ${ }^{0}$ 5.452, de $1^{\circ}$ de maio de 1943 (BRASIL, 1943) -, que representa um importante avanço da proteção e dos direitos do trabalho no Brasil. ${ }^{5}$ De acordo com Antunes (2015), a CLT, mesmo excluindo, à época, os trabalhadores rurais do acesso aos direitos - o que evidenciou o poder da aristocracia agrária brasileira -, resulta de um processo de modernização capitalista no país, engendrado nos anos 1930, e que foi palco de intensos conflitos e contradições, com forte presença das lutas operárias. A CLT, com uma faceta revestida de dádiva e outorga, emerge como uma legislação social protetora do trabalho, como uma espécie de constituição do trabalho no Brasil.

2 A Lei no 5.107, de 13 de setembro de 1966, cria o Fundo de Garantia do Tempo de Serviço (FGTS), que substituiu a estabilidade no emprego prevista na CLT após dez anos de vínculo na mesma empresa. Com o FGTS, as demissões são facilitadas.

3 Alterada posteriormente pela Lei $n^{0} 11.324$, de 19 de julho de 2006. Uma importante conquista e avanço no âmbito dos direitos para trabalhadores domésticos foi a aprovação da "PEC das domésticas”, consolidada pela Lei Complementar n 150 , de $1^{\circ}$ de junho de 2015, que dispõe sobre o trabalho doméstico.

4 A Constituição Federal de 1988 amplia os direitos sociais aos trabalhadores domésticos, como acesso ao salário mínimo, repouso semanal, férias remuneradas, licença maternidade, aposentadoria etc.

5 Porém, a nova legislação trabalhista (Lei n 13.467), aprovada e vigente desde 2017, expressa um desmonte efetivo e absoluto da CLT (ALVES, 2017). 
Considerando os antecedentes históricos e as transformações no mercado de trabalho brasileiro, entre os anos de 1950 a 1980, ocorreu um crescimento do setor secundário, que passou de 20,5\% para 38,6\% do Produto Interno Bruto (PIB), enquanto o setor primário apresentou queda de $29,4 \%$ para $10,7 \%$. Nesse período, o peso relativo do setor terciário permaneceu inalterado. Nas décadas subsequentes, o setor primário perdeu $46 \%$ do seu peso relativo, ao passo que o setor secundário reduziu sua participação no PIB em 35,5\%. Já o setor terciário apresentou um crescimento de 36,9\%, passando a representar 70\% do PIB do país no ano de 2013, o que demonstra uma nova configuração do mercado de trabalho brasileiro (POCHMANN, 2014, p. 30). Ou seja, de uma sociedade historicamente marcada pelo padrão agroexportador e sustentada na monocultura, no escravismo e no latifúndio, com destaque para os ciclos da cana-de-açúcar, da mineração, do café e da borracha, o Brasil passa, a partir da segunda metade do século XX, a assumir novas configurações no mercado de trabalho, tendo em vista o processo de industrialização e urbanização, além da expansão do emprego no setor industrial e de serviços. ${ }^{6}$

Porém, mesmo nesse contexto de mudanças sociais e econômicas, o Brasil conserva os traços de uma forte desigualdade social e concentração de renda e riqueza. ${ }^{7}$

6 Entre os anos de 1930 e 1980, o Brasil experimentou uma significativa expansão do emprego assalariado-formal, pois, a cada 10 (dez) empregos gerados, 8 (oito) eram assalariados-formais (POCHMANN, 1997). Durante o governo de Getúlio Vargas, instituiu-se, mediante o Decreto n ${ }^{\circ}$ 21.175, de 21 de março de 1932, a Carteira Profissional de Trabalho para trabalhadores com idade superior a 16 anos, o que significou uma iniciativa importante para a consolidação dos direitos trabalhistas no Brasil.

7 O Brasil, país de dimensão continental, com população estimada de 208,5 milhões de habitantes (IBGE, 2018), e apesar de compor os BRICS como um dos países de economia emergente (juntamente com Rússia, Índia, China e África do Sul), ocupa a $9^{a}$ posição em desigualdade no mundo, com IDH (Índice de Desenvolvimento Humano) de 0,759 e Índice de Gini de 0,627 (FGV, 2019). Metade da população brasileira vive com menos de um salário mínimo mensal, estipulado, até dezembro de 2019, em R \$ 998,00 (IBGE, 2019). Além disso, o sistema tributário brasileiro é regressivo, o que significa taxas elevadas sobre bens e serviços, penalizando a população mais pobre e com rendimentos menores. 
Em um contexto de crise internacional do capitalismo, durante a década de 1970, Mattoso e Pochmann (1998) assinalam que as principais características socioeconômicas e político-culturais do Brasil nessa fase eram a acentuada urbanização, com diversificação industrial; a produção voltada para o mercado interno; a forte presença do Estado (sendo que entre 1964 e 1985 vigorou o regime de ditadura civil-militar); abertura econômica ao capital estrangeiro (com participação de empresas multinacionais); heterogeneidade produtiva, apesar de um processo produtivo padronizado e de massa; baixos salários; reduzido nível organizativo do empresariado nacional; relações de trabalho baseadas em formas autoritárias; baixa representação sindical nos locais de trabalho; baixo nível de escolaridade; e acesso desigual aos direitos e serviços sociais, dentre outras.

A década de 1980 é marcada pela acentuação da crise no Brasil, com taxas elevadas de inflação, estagnação econômica e derrocada do regime ditatorial-militar. Nesse período, emergem na cena política brasileira movimentos sociais que passam a tensionar as correlações de forças instituídas e a ditadura civil-militar. São exemplos desse processo de efervescência social o surgimento do Partido dos Trabalhadores (PT) em 1980 e da Central Única dos Trabalhadores (CUT) em 1983, o protagonismo do novo sindicalismo, o movimento em defesa da Reforma Sanitária e o Movimento dos Trabalhadores Rurais Sem Terra (MST), dentre outros que tiveram papel fundamental na luta pela redemocratização do país, pelos direitos sociais e pela cidadania, o que resultou no fim do regime ditatorial-militar e, posteriormente, na Constituição Federal de 1988 (BRASIL, [2016a]), marco importante para a instituição tardia da proteção social brasileira. ${ }^{8}$

8 Nesse novo ordenamento democrático, a Constituição Federal de 1988 apresenta a concepção de seguridade social, que congrega a saúde, a previdência e a assistência social como direitos de cidadania e deveres do Estado, ou seja, a saúde como um direito universal, a previdência baseada na lógica do seguro contributivo e a assistência social a quem dela necessitar, mediante critérios de seletividade (FLEURY; PINHO, 2018). 
No que se refere ao sindicalismo, segundo Mattoso e Pochmann (1998), durante os anos 1980, o movimento sindical assumiu, mesmo com inúmeros entraves, uma dimensão diferenciada, rompendo com os limites repressivos do regime ditatorial-militar. Nesse período, observa-se um aumento do número de sindicalizados, novos movimentos de greve e uma crescente participação dos sindicatos no cenário social, político e econômico do país. Porém, mesmo após a promulgação da Constituição Federal de 1988 (CF/88), os sindicatos permaneceram com uma representação pequena dentro das empresas.

\section{O Brasil nos tempos neoliberais e as mudanças nas relações de trabalho}

Ao analisar a configuração do mercado de trabalho no Brasil, é preciso também considerar as particularidades do país a partir de sua posição geopolítica e socioeconômica no contexto mundial, pois os países da América Latina e, no caso específico, o Brasil, possuem características sui generis em relação aos países do "capitalismo central”. Nesse sentido, compreender as particularidades do mercado de trabalho brasileiro significa também considerar a forma como o país se integra ao mercado mundial, sobretudo nas últimas décadas, com o processo globalizado de financeirização da economia.

Na década de 1990, com a ofensiva neoliberal adotada após o Consenso de Washington de 1989, ${ }^{9}$ profundas mudanças ocorreram no mercado de trabalho brasileiro, com efeitos nocivos para os direitos e a proteção social da classe trabalhadora. As medidas neoliberais começam a ser implementadas no Brasil durante o governo de Fernando Afonso

9 Em novembro de 1989, na capital dos Estados Unidos, funcionários do governo norte-americano e dos organismos financeiros internacionais ali sediados, como o FMI, o Banco Mundial e o BID, reuniram-se com o objetivo de realizar uma avaliação das reformas econômicas empreendidas nos países da região. O Brasil aderiu às medidas do Consenso de Washington no período do governo Collor de Mello (1990-1992), quando, no intuito de solucionar o crescimento desordenado da inflação, foram adotadas medidas que propiciaram uma onda de crises e privatizações (BATISTA, 2001). 
Collor de Mello (1990-1992) e ganham continuidade nos governos de Itamar Franco (1992-1994) e de Fernando Henrique Cardoso (1995-2002).

O Brasil, a partir de uma abertura comercial e financeira indiscriminada, integra-se à dinâmica competitiva da economia internacional, elevando as taxas de importação e, ao mesmo tempo, recuando nas exportações, o que provocou um intenso processo de desestruturação do mercado de trabalho, com crescimento exponencial do desemprego e de formas precárias e flexíveis de trabalho (MATTOSO; POCHMANN, 1998). ${ }^{10}$

Além disso, nesse cenário de incorporação da política neoliberal, ocorreu uma reforma administrativa e gerencial do Estado, dando início a um amplo processo de privatização do patrimônio público e de redução das responsabilidades estatais no tocante aos serviços públicos e às políticas sociais. A partir dessa realidade neoliberal, caracterizada e acentuada pelo desmonte da proteção social, ocorre uma redução das greves (conforme o gráfico 1), tendo em vista a maior dispersão e fragmentação das ações sindicais e coletivas, que, diante dos direitos sociais em constante ameaça, passam a atuar de forma defensiva e negociadora. O que ocorre diante desse processo de significativas transformações é uma nova orientação do sindicalismo. Se, nos anos 1970 e 1980, o sindicalismo brasileiro se caracterizava por uma dimensão combativa e radical, nos anos 1990, sob a pressão neoliberal, ele se redireciona e se torna mais defensivo e conciliador (ANTUNES, 2018).

Os anos 1980 são marcados pela organização coletiva e potencialidade das lutas da classe trabalhadora, o que pode ser evidenciado pelo número de greves ocorridas no período. O movimento sindical ganha destaque na cena política brasileira nesse momento histórico e as greves passam a expressar o principal instrumento de luta, reivindicação e pressão da classe trabalhadora. O gráfico 1 apresenta a quantidade de greves ocorridas no Brasil (em números absolutos) de 1985 até a atualidade, com o objetivo de mostrar os períodos de maior intensificação do movimento grevista e as fases de refluxo da organização sindical, que se relacionam

${ }^{10}$ Conforme dados do Dieese, a taxa de desemprego em São Paulo no ano de 1989 era de 8,7\%, passando em 1997 para 16,6\% (MATTOSO; POCHMANN, 1998). 
com a dinâmica produtiva e o contexto social, econômico e político do país. Ao se observar o número de greves realizadas no Brasil nas quatro últimas décadas, evidencia-se a importância do sindicalismo, sobretudo a partir dos anos 1980, como movimento de organização e representação dos trabalhadores na luta por direitos sociais. Mesmo posteriormente, nos anos 1990, em um cenário de reestruturação produtiva e política neoliberal, as greves tiveram um papel importante no cenário nacional. Já na primeira década dos anos 2000, observa-se uma queda no número de greves. Isso pode ser explicado pelo contexto da época, marcado pela redução do desemprego, investimento em políticas de geração de emprego, programas de transferência de renda de cidadania para a população em situação de pobreza (a exemplo do Programa Bolsa-Família) e também uma política de valorização do salário mínimo, como se observa no gráfico 2.

Gráfico 1: Número de greves no Brasil no período de 1985 a 2018

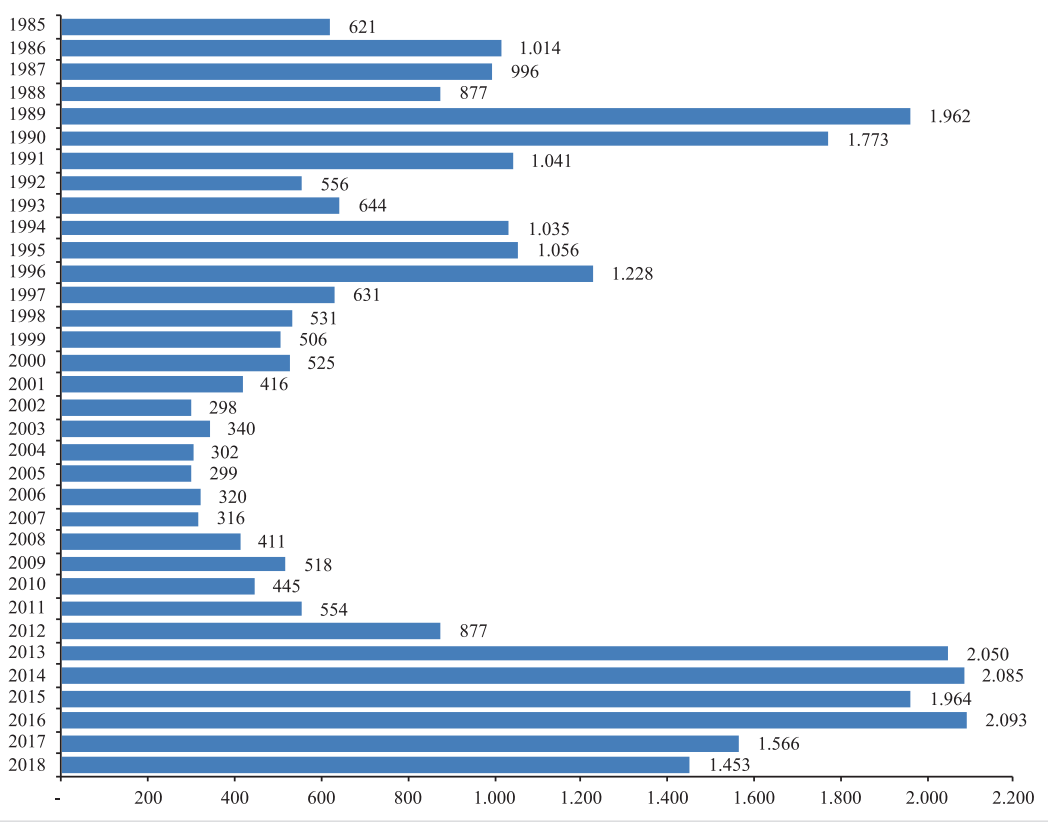

Fonte: Departamento Intersindical de Estatística e Estudos Socioeconômicos (Dieese), 2019a. Elaboração própria. 
Gráfico 2: Relação entre salário mínimo nominal (real) versus salário mínimo necessário. Mês de referência: janeiro, anos de 1995 a 2019 (valores em reais).

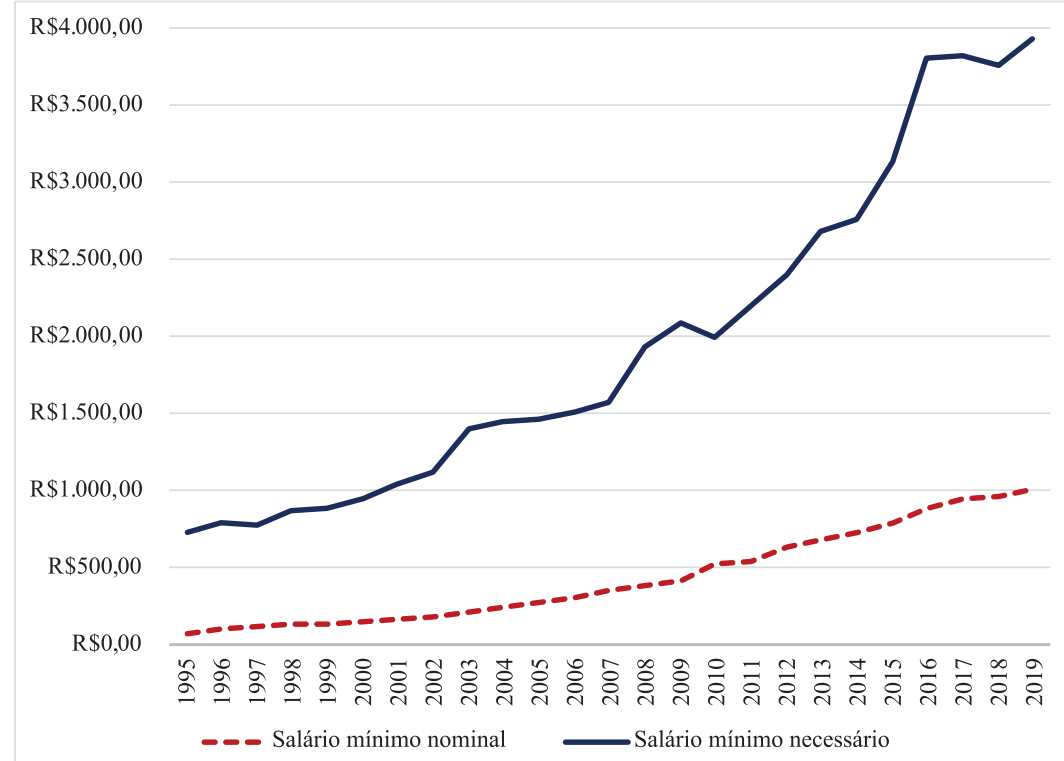

Fonte: Departamento Intersindical de Estatística e Estudos Socioeconômicos (Dieese), $2019 \mathrm{~b}$. Elaboração própria.

O gráfico 2 mostra a evolução do salário mínimo no Brasil e o salário que seria necessário para atender às necessidades básicas de uma família, tendo como referência os meses de janeiro entre 1995 e 2019. Mesmo tendo havido uma política de valorização do salário mínimo nos últimos anos, sobretudo durante os governos de Luiz Inácio Lula da Silva (2003-2010) e de Dilma Rousseff (2011-2016), se compararmos o salário mínimo nominal, ou seja, o salário mínimo vigente e estipulado por lei, com o salário mínimo necessário para atender às necessidades de uma família no Brasil, constatamos uma profunda distância entre o que é o salário real, obtido mensalmente pela classe trabalhadora, e o que seria ideal para suprir as necessidades humanas básicas, como alimentação, saúde, moradia, educação etc.

Ainda sobre o movimento grevista no Brasil, conforme apresentado no gráfico 2, a partir de 2013 observa-se um crescimento no número 
de greves, tendo em vista o cenário de crise e instabilidade político-econômica e o aumento do desemprego no Brasil.

No início dos anos 2000, verifica-se uma queda na taxa de desemprego; porém, a partir de 2015, sob o efeito da crise política e econômica no país, constata-se um crescimento dos indicadores de desemprego, que se intensificam até a atualidade, conforme demonstra o gráfico 3.

\section{Gráfico 3: Taxa de desemprego no Brasil} no período de 2004 a 2018

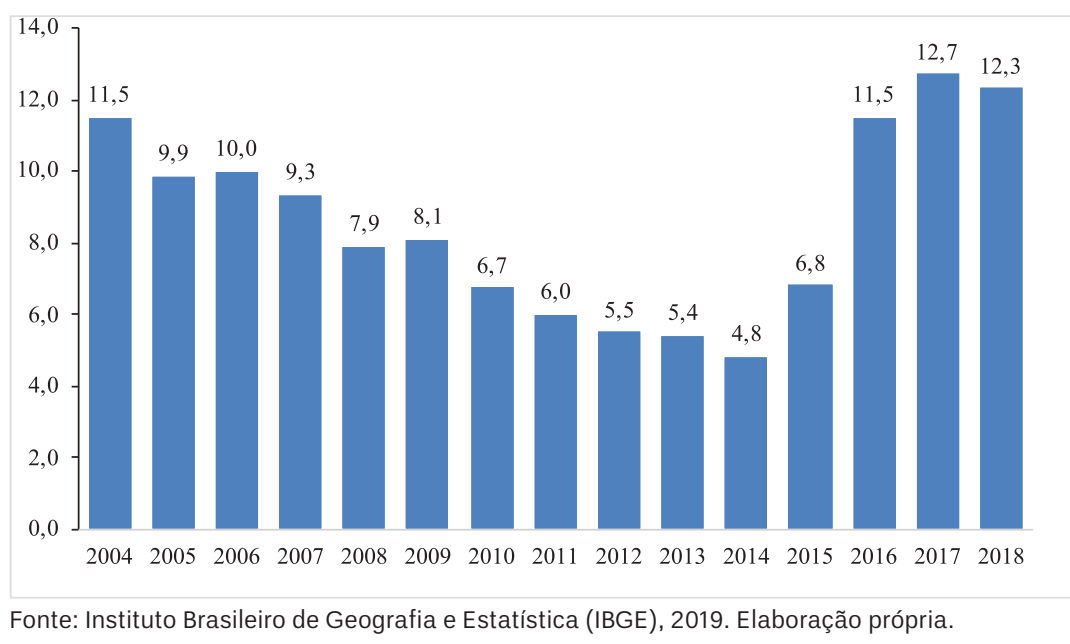

Apesar de se observar uma pequena queda na taxa média de desemprego no ano de 2018 em comparação com o ano de 2017, é importante destacar, conforme os dados do Instituto Brasileiro de Geografia e Estatística (IBGE, 2019), que a maioria dos empregos gerados nesse período se refere a trabalho precário, flexível, temporário e por conta própria. Ainda com base nos dados do IBGE/Pnad (Pesquisa Nacional por Amostra de Domicílio), o Brasil encerrou o primeiro trimestre de 2019 com uma taxa de desemprego equivalente a 12,7\%, o que significa que 13,4 milhões de pessoas em idade ativa/laborativa encontram-se desempregadas (IBGE, 2019). 


\section{A construção contraditória dos direitos sociais no Brasil: crises, contrarreformas e retrocessos sociais}

A consagração da seguridade social na $\mathrm{CF} / 88$, contemplando as políticas de saúde, previdência e assistência social, compreendidas como direitos de cidadania e deveres do Estado, representou uma importante e progressiva conquista no âmbito da construção da proteção social brasileira. Porém, na contramão da consolidação desses direitos e em um contexto de crise, nos anos 1990, o Estado brasileiro aprofundou, por meio de ajustes e medidas de austeridade, a privatização dos serviços e políticas sociais, como é o caso do "Programa Comunidade Solidária”, constituído em 1995 no governo de Fernando Henrique Cardoso (PSDB), que estimulava ações voluntárias e transferia responsabilidades públicas para entidades da sociedade civil.

O que se observa é um contexto desfavorável para a institucionalização e consolidação da seguridade social brasileira em uma perspectiva universalista dos direitos, diante da redução das responsabilidades do Estado em relação às políticas públicas e aos serviços sociais. São adotadas ações e medidas direcionadas à privatização de empresas estatais e de serviços sociais, tendo como objetivo atender aos anseios do mercado financeiro e promover a estabilização monetária.

Diante desse cenário, pode-se dizer que os direitos sociais no Brasil se constituíram com base em um sistema misto, de combinação entre o público e o privado, entre universalização e focalização, entre responsabilidade do Estado e responsabilidade individual.

Ainda nos anos 1990, dentre as medidas implementadas e relacionadas ao mercado de trabalho, destaca-se a Súmula n ${ }^{0}$ 331/1993, do Tribunal Superior do Trabalho (TST), que trata do trabalho temporário e da terceirização de atividades-meio, abrindo amplo caminho para os contratos terceirizados, para a informalidade, para o subemprego, para a flexibilização e para a precarização do trabalho. Nesse período, acontece também uma significativa migração de empresas produtoras de artigos manufaturados para regiões consideradas pobres, de baixa organização sindical e ainda não industrializadas do país, com o objetivo 
de reduzir os custos contratuais do trabalho, obter incentivos fiscais do Estado e diminuir a presença e controle dos sindicatos.

Nessa mesma década, durante o governo de Fernando Henrique Cardoso, ocorre a aprovação da Contrarreforma da Previdência Social (conforme a Emenda Constitucional no 20, de 1998). ${ }^{11}$ Inúmeros foram os argumentos e justificativas ideopolíticas para o encaminhamento e aprovação da Contrarreforma. Dentre os argumentos, destacava-se o suposto déficit e desequilíbrio financeiro, a mudança demográfica populacional e a existência de dois regimes previdenciários distintos, o que poderia reforçar desigualdades e privilégios entre trabalhadores dos setores públicos e privados.

O sistema previdenciário brasileiro se organiza em dois modelos, a saber: o Regime Geral de Previdência Social (RGPS), que abrange os trabalhadores do setor privado e é administrado pelo Instituto Nacional do Seguro Social (INSS), autarquia de natureza pública, e o Regime Próprio de Previdência Social (RPPS), que contempla os servidores públicos e está sob a gestão do Estado.

Porém, na defesa argumentativa das contrarreformas, ao se sustentarem tais medidas com base na necessidade de sanar déficits, não se divulga a transferência de receitas do orçamento da seguridade social para o orçamento fiscal, com a finalidade do pagamento de juros e amortização da dívida pública. Desde a implantação do Plano Real, em 1994, foi instituído pelo governo federal o Fundo Social de Emergência, alterado para Desvinculação das Receitas da União (DRU) em

${ }^{11} \mathrm{O}$ uso do termo “Contrarreforma” se dá pelo entendimento de que essas medidas, baseadas na ortodoxia neoliberal, caminham na contramão de mudanças progressivas no âmbito das garantias e dos direitos sociais. Diante do seu teor regressivo e de consequências deletérias para o conjunto da população, o termo contrarreforma se torna mais apropriado, pois, na medida em que representa perdas históricas para a classe trabalhadora, atende aos anseios do mercado capitalista-financeiro. A agenda contrarreformista tem como objetivo precípuo a valorização do capital a partir da elevação das taxas de lucro, ou seja, atende aos interesses da lógica de acumulação do capital, ao tempo em que dá lugar a ataques e retrocessos no campo dos direitos sociais da população. Medidas contrarreformistas são apresentadas, segundo Braz (2017, p. 96), como um quadro paradisíaco para o capital, a partir de uma “[...] maior repressão sobre os trabalhadores e melhores condições para a acumulação capitalista.” 
1999, o que permite a transferência dos recursos das contribuições para outras áreas de interesse do Estado (ARAUJO, 2009).

Com a aprovação da Contrarreforma Previdenciária de 1998, estabeleceu-se o critério do tempo de contribuição para o regime previdenciário, em substituição ao tempo de serviço.

No caso dos regimes próprios (RPPS), o tempo de contribuição deve ser combinado com uma idade mínima. Além do mais, criou-se o regime de previdência complementar, de caráter privado, demonstrando os efeitos danosos da agenda neoliberal e a desconsideração dos princípios da seguridade social estabelecidos na carta constitucional.

Outra Contrarreforma da Previdência foi encaminhada e aprovada pelo Congresso Nacional em 2003, durante o governo de Luís Inácio Lula da Silva (2003-2010), do PT. ${ }^{12}$ Essa Contrarreforma, descrita na Emenda Constitucional $n^{\circ}$ 41, de 2003, afetou especialmente os servidores públicos, não tendo efeitos para os trabalhadores do setor privado regidos pelo RGPS. Dentre as alterações dessa reforma, estão a eliminação da integralidade salarial na aposentadoria; a criação de um limite (teto) do valor dos benefícios para os novos ingressantes no serviço público; o estabelecimento de critérios para o valor das novas pensões; e a obrigatoriedade da taxação dos servidores inativos e pensionistas, com base na mesma alíquota dos servidores ativos, com um limite mínimo de isenção, dentre outras medidas que demonstram a busca pela convergência e unificação das regras entre os dois regimes previdenciários (ARAUJO, 2009).

As contrarreformas demonstram a sequência e o aprofundamento dos ajustes neoliberais, que caminham no sentido oposto ao do sistema

\footnotetext{
${ }^{12}$ Após o lançamento da Carta ao Povo Brasileiro, Lula é eleito em 2002 com uma plataforma política conciliadora, aliando o objetivo de atender os interesses e necessidades do mercado financeiro a uma política de inclusão social, baseada na distribuição de renda e que se deu, sobretudo, pela ampliação do consumo de massa no mercado interno. Isso foi possível a partir de uma política de valorização do salário mínimo, dos programas de transferência de renda e da facilitação de acesso ao crédito (PINHO, 2016). Nessa lógica, a cidadania estava atrelada ao consumo de bens e serviços, o que passou a ser objeto de duras críticas aos governos do PT.
} 
de proteção social, isto é, na contramão de uma perspectiva universalista dos direitos sociais, pois o que se observa é uma abertura e amplo estímulo ao investimento e crescimento dos fundos privados de previdência - ou seja, o direito à previdência social passa a ser subordinado aos interesses, regras e ditames do mercado financeiro.

O desenho da previdência social no Brasil, após a aprovação das contrarreformas, aproxima-se de um modelo misto, tendo em vista que o Estado assegura uma "previdência básica e pública” e o mercado ganha espaço com o incentivo à "previdência complementar-privada” (ARAUJO, 2009).

Ainda no governo Lula, foi criado, pela Lei Complementar $n^{\circ} 123$, de 14 de dezembro de 2006, e regulamentado pelo Decreto $n^{\circ} 6.042$, de 12 de fevereiro de 2007, o Plano Simplificado de Previdência Social (PSPS), com o objetivo de contemplar trabalhadores autônomos, contribuintes individuais e facultativos, com percentual de contribuição reduzido de $20 \%$ para $11 \%$. Outras medidas foram criadas durante o governo Lula, como o Programa Nacional de Microcrédito Produtivo Orientado (PNMPO), instituído pela Lei ${ }^{0} 11.110$, de 2005, que direciona empréstimos bancários a pessoas físicas ou a pequenos empresários, com o objetivo de incentivar o empreendedorismo.

No governo Lula, observa-se uma continuidade das políticas econômicas e financeiras orientadas pela ortodoxia neoliberal, combinada, todavia, com o investimento em políticas sociais, como é o caso da expansão de políticas de transferência de renda, sendo o Programa Bolsa-Família destinado às famílias em situação de extrema pobreza um exemplo clássico das medidas implementadas pelos governos do PT. ${ }^{13}$

${ }^{13}$ Na realidade, o governo Lula não realizou rupturas com a política econômica vigente, pois preservou benefícios ao capital financeiro, manteve a estrutura fundiária concentrada e as privatizações, sob a forma das parcerias público-privadas, e incentivou os fundos de pensão (ANTUNES, 2018). A novidade do período Lula é a inauguração de um ciclo político e econômico denominado de neodesenvolvimentismo, que, segundo Boito Júnior (2018), consiste em um programa político, econômico e social que busca o crescimento da economia aliado a programas de transferência de renda, mas sem rompimento com as prerrogativas neoliberais. O chamado neodesenvolvimentismo integra um conjunto de medidas políticas, econômicas e sociais que visam, dentre outros fatores, a destinação de recursos públicos para programas 
Além disso, nesse período houve crescimento do emprego formal e queda do desemprego (gráfico 3), uma política de valorização do salário mínimo (gráfico 2) e a ampliação do ensino superior e técnico em nível federal. Ou seja, a partir de uma estratégia baseada na conciliação de classes, os governos petistas se alicerçaram em uma política voltada para o crescimento econômico, de forma a atender às demandas do capital financeiro, e ao mesmo tempo implementaram, com muitas limitações, medidas de inclusão social, por meio de investimentos em programas e políticas sociais.

A política econômica aplicada nos governos do PT manteve as bases neoliberais estabelecidas com o Plano Real, especialmente o chamado tripé macroeconômico, que engloba o superávit primário, o controle do câmbioeas metas deinflaçãodeterminadaspelas elevadas taxas dejuros. ${ }^{14}$

Os efeitos da crise econômica internacional dos anos de 2007 e 2008 chegaram ao Brasil, especialmente, com a desaceleração econômica de 2012 e a recessão de 2015. O impacto da crise e da perda do dinamismo econômico pode ser verificado nos dados sobre o PIB, que em 2011 apresenta um crescimento de 2,7\%, e em 2012, de apenas 0,9\%. Nesse período, o governo de Dilma Rousseff (2011-2016), também do PT, adota medidas anticíclicas baseadas na redução da taxa de juros, no aumento de créditos subsidiados a empresas por meio de bancos públicos, na redução de impostos sobre os produtos industrializados, na desvalorização da moeda, no controle dos fluxos de capital

de transferência de renda, pois se entende que não é possível superar o subdesenvolvimento brasileiro de modo linear, natural e espontâneo, seguindo as regras neoliberais do mercado. Por isso a importância de políticas sociais e programas como os de transferência de renda (POCHMANN, 2013).

${ }^{14}$ Os governos Lula e Dilma mostraram suas limitações diante de “[...] uma incapacidade em promover investimentos sociais de profundidade nos serviços públicos, dada a submissão a um pacto conservador da governabilidade que exigia a manutenção e preservação da forma política do Estado neoliberal no Brasil. Disso resultou a incapacidade política dos governos [...] em romperem com o ciclo do pagamento de juros e amortização da dívida pública, subordinada aos interesses do capital financeiro [...]” (MARIANO, 2017, p. 266). 
externo como forma-barreira para a valorização cambial e na redução do preço da eletricidade, dentre outras (SINGER, 2015).

Durante o governo de Dilma Rousseff, outras medidas contrarreformistas foram aprovadas em relação à previdência social, como é o caso da criação do Fundo de Previdência Complementar (Funpresp) no ano de 2012, que passou a vigorar em 2013 para os ingressantes no serviço público. Com essa contrarreforma, a partir do argumento ideopolítico da isonomia entre trabalhadores dos setores públicos e dos setores privados, os valores das aposentadorias dos servidores públicos federais (ingressantes a partir de 2013) passaram a ser equiparados aos do limite-teto dos trabalhadores do setor privado, do RGPS. O Funpresp, instituição de natureza privada, é criado como estímulo à previdência complementar para os trabalhadores públicos que recebem salários superiores ao teto-limite e objetivam auferir, após a aposentadoria, um benefício compatível ao recebido durante o período na ativa.

Em 2013, ocorreu no Brasil uma onda de greves que demonstravam as insatisfações da classe trabalhadora, além das Jornadas de Junho, em que grandes massas saíram às ruas em protesto contra o aumento das tarifas de transporte público, os cortes das políticas sociais e os gastos exorbitantes com a copa do mundo (BRAGA, 2016). A partir disso, alguns movimentos passaram a protagonizar o debate político com o lema do combate à corrupção. Tal cenário, diante de inúmeras denúncias envolvendo políticos e com a proporção alcançada pela Operação "Lava Jato", provocou um clima de instabilidade política, o que se tornou visível por meio do acirramento das eleições presidenciáveis de $2014 .{ }^{15}$

Diante do aprofundamento da crise social, econômica e política e do esgotamento da tática conciliatória adotada pelos governos petistas, iniciaram-se inúmeras pressões pela implementação de medidas regressivas, de ajuste e austeridade, baseadas em propostas de contrarreformas destinadas ao desmonte e dilapidação dos direitos sociais e trabalhistas.

${ }^{15}$ O resultado da disputa presidencial no segundo turno no Brasil em 2014 revela esse quadro: Dilma Rousseff (PT) obteve 51,64\% dos votos válidos, enquanto Aécio Neves (PSDB) alcançou 48,36\%. 
Em seu segundo mandato presidencial, iniciado em 2015, Dilma Rousseff convida Joaquim Levy para assumir o Ministério da Fazenda, e a partir de então, são adotadas medidas energéticas de austeridade e ajuste fiscal, com o objetivo de reduzir a inflação a partir de duros cortes nos gastos sociais e no orçamento público. Isso afetou drasticamente as políticas sociais, a exemplo da educação e da saúde, provocando um verdadeiro colapso no país diante da recessão generalizada, crescimento do desemprego, contração do PIB e diminuição das receitas fiscais, que agravaram o quadro da dívida pública (PINHO, 2016).

Os últimos anos do governo de Dilma Rousseff foram marcados pela queda da arrecadação, com impactos significativos no PIB, crise fiscal e desaceleração do crescimento, o que provocou um profundo descontentamento do empresariado e dos setores médios. O Brasil entrou em colapso, com o aprofundamento da crise socioeconômica, a deflagração de uma crise político-institucional, o crescimento do desemprego e uma profunda recessão, provocando o processo de impeachment em 2016. ${ }^{16}$

A alegação para a condução e sustentação do impeachment baseou-se no argumento de violação da Lei de Responsabilidade Fiscal (LRF), considerando que Dilma havia cometido crime de responsabilidade mediante o atraso no repasse de recursos financeiros do Tesouro Nacional para os bancos públicos (como o Banco do Brasil e a Caixa Econômica Federal) para o pagamento de programas sociais, dentre eles o Programa Bolsa-Família e o Programa Minha Casa, Minha Vida. Esse processo ficou conhecido como "pedaladas fiscais” (FLEURY; PINHO, 2018). ${ }^{17}$

${ }^{16}$ Para Cavalcanti e Venerio (2017), do ponto de vista jurídico-formal houve um impeachment, mas do ponto de vista político houve um golpe, ou seja, o que ocorreu se apresenta na forma de impeachment, mas com conteúdo de golpe. Não como um golpe clássico de Estado, caracterizado pelo uso da força e violência, mas, pelo contrário, segundo Braz (2017), sem rupturas institucionais significativas, dentro do funcionamento das instituições democráticas burguesas, com o amparo da Justiça e do Legislativo.

${ }^{17}$ Em 21 de outubro de 2015, os advogados Hélio Bicudo, Miguel Reale Júnior e Janaína Paschoal apresentaram e protocolaram na Câmara dos Deputados um pedido de impeachment de Dilma Rousseff, alegando que a presidenta teria editado decretos de abertura de crédito suplementar sem a autorização do Congresso e utilizado bancos 
Dentre os fatores que desencadearam a derrocada do governo Dilma Rousseff, estão a queda das taxas de crescimento e diminuição da arrecadação tributária, a crise fiscal, a instabilidade política e a crise institucional no Congresso Nacional, agravada pelo recrudescimento de uma agenda parlamentar conservadora e as crescentes denúncias de corrupção que a mídia passou a reverberar a partir da Operação "Lava Jato”, dentre outras (PINHO, 2016). Tudo isso sedimentou o caminho para o golpe parlamentar-midiático-empresarial-jurídico revestido de faceta democrática, que alçou Michel Temer à Presidência da República (FLEURY; PINHO, 2018).

O golpe, chancelado pelo Congresso Nacional com o respaldo do poder judiciário, da mídia e dos setores médios e empresariais, notabilizou as fraturas e limites da democracia (neo)liberal-burguesa brasileira, em um tempo histórico de acirramento dos conflitos e contradições na arena das lutas de classes. Isso significa que a consolidação do golpe não se deu de forma apaziguadora, pacífica e harmônica, baseada na vontade geral e popular. Pelo contrário, ocorreram e ainda estão presentes nesse contexto de radicalização e polarização da luta de classes inúmeros confrontos, manifestações e resistências.

Antes mesmo da ruptura oficial com o governo de Dilma Rousseff, o golpe já se anunciava quando o Partido do Movimento Democrático Brasileiro (PMDB), ao qual pertencia o então vice-presidente Michel Temer, apresentou, em 29 de outubro de 2015, o documento-programa Uma Ponte para o Futuro (PMDB, 2015), sinalizando uma aproximação e alinhamento aos anseios do mercado financeiro a partir da necessidade da realização do ajuste fiscal como mecanismo de contenção da dívida pública e da inflação. Também apontava para a necessidade de aumento da produtividade com base na redução dos custos trabalhistas; aumento da flexibilização e generalização da terceirização; redução do fundo social por meio da eliminação de obrigações orçamentárias com as políticas sociais; e privatizações e abertura comercial, sobretudo ladas fiscais” (CAVALCANTI; VENERIO, 2017). 
em relação aos Estados Unidos e Europa (FLEURY; PINHO, 2018). Ou seja, era apresentada uma agenda programática ancorada nos princípios ideopolíticos e econômicos do neoliberalismo, que acenava, na realidade, como "uma ponte para o passado” em matéria de desmonte e retrocessos históricos relacionados aos direitos sociais de cidadania.

Em 29 de março de 2015, o PMDB de Michel Temer, até então partido da base aliada de Dilma Rousseff, anuncia oficialmente a ruptura com o PT, deflagrando uma crise político-institucional. Tal acontecimento representou para Dilma uma significativa perda da base legislativa, dificultando a sua governabilidade e atuação como chefe de Estado. Esse cenário de ruptura das alianças políticas (com efeitos diretos na perda de apoio da base parlamentar), de convulsão e de efervescência social - considerando a continuidade dos protestos organizados pela oposição e por setores médios e empresariais, que contavam com o aparato e a espetacularização dos grupos oligopolistas detentores dos meios de comunicação no país - criou as bases para o processo de impeachment de Dilma, que culminou na sua deposição em 2016. ${ }^{18}$

Com a chegada à Presidência, Michel Temer adotou medidas neoliberais severas de cortes e desmonte do sistema de proteção social brasileiro. Nos seus dois anos e meio de governo, com o apoio do empresariado e da maioria dos parlamentares, Temer implementou, de forma célere, o desmonte e a dilapidação da proteção social brasileira. A partir da orientação ortodoxa neoliberal, as políticas sociais se subordinam às prerrogativas das políticas econômicas de austeridade, pois, sob a ótica ofensiva do mercado financeiro, a garantia e a ampliação dos direitos sociais como forma de expansão da democracia e da cidadania são obstáculos para a reprodução ampliada e acumulação do capital.

\footnotetext{
${ }^{18}$ No dia 17 de abril de 2016, o processo de impeachment foi aprovado em votação na Câmara dos Deputados, com 367 votos favoráveis e 137 contrários. No Senado Federal, a votação ocorreu em 31 de agosto de 2016, com 61 votos favoráveis e 20 contrários, destituindo Dilma do mandato de Presidenta da República. Esses episódios das votações, com cenas vexatórias e vergonhosas transmitidas pela Rede Globo, entram para a história como um triste e decadente capítulo da pobre e frágil democracia brasileira (BRAZ, 2017).
} 
Seguindo integralmente esse receituário, em 2016 foi aprovada a Emenda Constitucional no 95, conhecida como "PEC do Teto" (BRASIL, 2016b), que estabeleceu o congelamento dos gastos públicos pelo período de 20 (vinte) anos, afetando as políticas de seguridade social. As consequências dramáticas dessa medida já são constatadas, como é o caso das políticas de saúde e educação, que enfrentam inúmeras dificuldades na oferta e continuidade dos serviços em razão dos cortes orçamentários. ${ }^{19}$

Também foi aprovada a Contrarreforma Trabalhista (Lei n ${ }^{0} 13.467$, de 2017) com efeitos nocivos e inúmeros retrocessos para os direitos sociais e trabalhistas. ${ }^{20}$

${ }^{19}$ A Emenda Constitucional no 95/2016 resultou das Propostas 241 e 55, que tramitaram, respectivamente, na Câmara dos Deputados e no Senado Federal, com votação final em segundo turno nessa última casa legislativa, no dia 16 de dezembro de 2016. Foram inseridos no Ato das Disposições Constitucionais Transitórias (ADCT) dispositivos adotando o novo regime fiscal, que estabelece o limite para os gastos do governo federal a vigorar pelos próximos 20 (vinte) anos. Ou seja, esse novo regime valerá até 2036 e começou a ser aplicado à educação e à saúde em 2018 (MARIANO, 2017). Tal medida expressa os reais compromissos do Estado brasileiro ao seguir a cartilha do receituário neoliberal, ou seja, Estado mínimo para os direitos de cidadania, as políticas sociais e os serviços públicos.

${ }^{20}$ Pode-se dizer que a Contrarreforma ganha forma e efeito com a Lei ${ }^{\circ} 13.429$, de 31 de março de 2017, que altera a Lei $n^{\circ}$ 6019/1974 (que disciplinou o trabalho temporário no Brasil), na medida em que amplia as modalidades de contrato de trabalho temporário e possibilita a terceirização das atividades-fim (principais), seguida da Lei $n^{0}$ 13.467, de 13 de julho de 2017, que altera a CLT de 1943. Cabe sublinhar que sua aprovação ocorreu em um curto prazo, com ausência de um amplo debate junto à sociedade e representantes sindicais. O projeto de "Reforma” Trabalhista (PL n ${ }^{\circ}$ 6.787/2016) foi votado na Câmara dos Deputados em 26 de abril de 2017, com 296 votos favoráveis e 177 contrários. Logo depois, em 11 de julho de 2017, o projeto de lei complementar (PLC n ${ }^{0}$ 38/2017) foi aprovado no Senado Federal com 50 votos favoráveis e 26 contrários. A aprovação da Contrarreforma, em um momento em que o Brasil vive uma politização do judiciário e uma judicialização da política, no cerne de um “Estado de exceção” marcadamente repressivo, censurador e persecutório, coloca na arena das lutas de classes desafios hercúleos para a classe trabalhadora, para os movimentos sociais e para o sindicalismo. 


\section{A Contrarreforma Trabalhista e a dilapidação dos direitos sociais}

De acordo com Alves (2017), o desmonte da proteção trabalhista, por meio do seu arcabouço jurídico-legislativo, é um processo que vem ocorrendo gradativa e permanentemente na realidade brasileira, sob a ofensiva do capitalismo predatório, mas a Contrarreforma Trabalhista é a expressão mais acabada, corrosiva e absoluta desse processo. ${ }^{21}$

A aprovação da Lei $n^{0} 13.429 / 2017$, que possibilita a terceirização irrestrita e desenfreada, ou seja, a contratação de terceirizados para a realização de atividades-meio e/ou atividades-fim, abre caminho para a desproteção total e absoluta de trabalhadores e trabalhadoras, corroborando para os processos de coisificação, intensificação e precarização, além do aumento de acidentes de trabalho e adoecimentos advindos da sobrecarga laboral.

Com isso, a desregulamentação e a flexibilização do trabalho tornam-se palavras de ordem no cerne de uma contrarreforma falaciosamente "modernizadora”. Com a contrarreforma, é criada a figura do empregado just in time. A Lei no 13.429/2017 amplia a utilização dos contratos temporários, possibilitando o uso indiscriminado da terceirização, para qualquer atividade, inclusive para a atividade principal (atividade-fim), seja no âmbito público ou privado. Permite também a substituição de trabalhadores efetivos por prestadores de serviços para a realização de quaisquer atividades (GALVÃO et al., 2017, p. 32).

De acordo com Antunes (2015), na sociedade da terceirização total, constata-se o aumento do desemprego, a desregulamentação do trabalho (com um maior contingente de mulheres nessas atividades, diante

21 “[...] a CLT foi sendo alterada historicamente por meio de leis, decretos, emendas constitucionais e medidas provisórias. Foram promovidas 233 alterações até 2016, $75 \%$ das quais ocorreram pela via legislativa. Na ditadura militar houve maior quantidade de decretos emanados do Executivo, sendo, ainda, importante lembrar que a CLT bem como as instituições do poder judiciário e do Ministério Público do Trabalho que a ela remetem passaram pelo crivo democrático dos legisladores constituintes, sendo fundamentais para a manutenção da plena cidadania social no mundo do trabalho” (GALVÃO et al., 2017, p. 14). 
da divisão sexual do trabalho) e índices elevados de lesões, acidentes e assédios, além da fragmentação da classe trabalhadora, tendo em vista os entraves da organização sindical. Nesse cenário, a terceirização, que era exceção (concentrada em serviços de limpeza, segurança, transporte, manutenção), torna-se a regra, passando a constituir o mecanismo vital de reprodução e acumulação capitalista, em detrimento dos direitos sociais e do trabalho.

Desde a Carta Constitucional de 1988, setores conservadores da classe dominante sustentam, sob a ótica neoliberal do mercado autorregulado, que uma legislação protetiva e o compromisso com os direitos sociais implicam entraves para a geração de empregos e para o "desenvolvimento" do país. ${ }^{22}$ Por isso, apontam a necessidade da realização de "reformas" a partir de um discurso amparado na "segurança jurídica”. Além do mais, argumentam que a legislação trabalhista promove injustiças ao criar duas classes de trabalhadores: os protegidos pela legislação e os desprotegidos, relegados à informalidade. Esse discurso, que oculta sua verdadeira face e teor, inverte a realidade, culpabilizando e penalizando trabalhadores e trabalhadoras pelo desemprego, pela desigualdade e pela informalidade no mundo trabalho (GALVÃO et al., 2017).

Além da terceirização irrestrita, a nova legislação trabalhista apresenta diversos aspectos regressivos, como é o caso do trabalho intermitente, também conhecido como contrato de zero hora, que garante que o trabalhador e a trabalhadora permaneçam subordinados à empresa contratante, pois esta passa a ter o direito de utilizar a força de trabalho disponível de acordo com as suas necessidades. A nova lei permite a prestação de serviços de forma descontinuada, com alternâncias de periodicidade, horário e dia, sendo o pagamento estabelecido conforme a proporcionalidade das horas e dos dias trabalhados. O trabalho intermitente poderá ser adaptado de acordo com a necessidade e

22 “A intolerância de nossas classes dominantes não é um fenômeno conjuntural. Historicamente elas sempre foram muito avessas a avanços sociais, mesmo aqueles que não comprometem os seus interesses econômicos” (BRAZ, 2017, p. 101). 
eventualidades, como é o caso do trabalho em finais de semana e em horários com maior número de demandas, dentre outros. Essa modalidade contratual subordina o trabalho às necessidades circunstanciais do empregador, pois o trabalhador, não tendo uma jornada pré-definida, fica disponível 24 horas diárias, vinculado a um contratante que poderá dispor de seu trabalho a qualquer momento, pagando apenas pelas horas trabalhadas. Nesse caso, o contratante deve avisar o contratado da atividade laborativa com três dias de antecedência, cabendo ao trabalhador aceitar ou não a oferta no prazo de até um dia. Não há nenhuma previsibilidade em relação ao número de horas contratadas nem à remuneração a ser recebida, produzindo incertezas e instabilidades para a vida e para as condições de sobrevivência da classe trabalhadora. Além da redução de direitos trabalhistas, isso também implica impacto na contribuição previdenciária. A remuneração do trabalho intermitente pode ser proporcional às horas trabalhadas, ou seja, não precisa corresponder ao estabelecido pelo salário mínimo. As consequências dessa modalidade contratual são desastrosas para os direitos sociais, para as condições de trabalho e para a saúde da classe trabalhadora (GALVÃO et al., 2017).

Outro ponto da nova legislação diz respeito ao contrato por tempo parcial. Essa modalidade, que não é atual, passa por alterações. Antes da contrarreforma, sua jornada era limitada a 25 horas semanais, mas a nova lei possibilita a contratação com jornadas de 26 a 30 horas, além de permitir a contratação inferior a 26 horas, com base em salário proporcional. Nessa modalidade contratual, observa-se um forte recorte de gênero, pois diante de uma realidade estruturada na divisão sexual do trabalho, as mulheres, com suas duplas e triplas jornadas laborais, passam a ocupar prevalentemente essas formas contratuais.

No que se refere ao trabalho autônomo, também previsto na nova legislação, como se sabe, o trabalhador autônomo é aquele que exerce atividade profissional sem vínculo empregatício, ou seja, por conta própria, assumindo todos os riscos e ônus do trabalho. Essa modalidade abre caminho para a "pejotização" de trabalhadores e trabalhadoras, na medida em que estes se tornam pessoas jurídicas. 
Também polêmica é a jornada laboral de 12 por 36 horas, pois esse tipo de jornada era baseado, anteriormente, em acordo coletivo, passando a ser possível a negociação por meio de acordo individual. Até então, era restrita a categorias profissionais específicas, como enfermagem, medicina, segurança/vigilância, passando a ser liberada de modo irrestrito para todas as atividades e profissões. A legislação também prevê a jornada de 12 horas por tempo ininterrupto, sem pausas ou intervalos para refeição e repouso, o que contribui para o aumento de acidentes e adoecimento ocupacional. Além de prejudicial à saúde física e mental e à segurança, essa modalidade é também nociva à vida social, pois afeta as relações familiares, os compromissos cotidianos, o lazer e a formação profissional (DIEESE, 2017, p. 8).

A nova legislação também instituiu o contrato de teletrabalho, conhecido como home office, que se caracteriza por atividades realizadas fora das dependências do empregador/empresa - ou seja, trabalho a distância, realizado em sua maioria nas residências dos trabalhadores. O teletrabalho também se caracteriza por jornadas longas de trabalho e transferência de responsabilidades e ônus para os trabalhadores, como no caso de acidentes e adoecimento. A responsabilidade pelos equipamentos, infraestrutura e demais despesas serão previstas em contrato escrito, podendo ser de responsabilidade do trabalhador. Torna-se um grande atrativo para o empregador a possibilidade desse tipo de contratação, pois não há limites de jornada nem custos fixos com infraestrutura (DIEESE, 2017).

Sobre a rescisão contratual, a nova lei estabelece "comum acordo" entre empregador e empregado no ato rescisório, mas é importante salientar que essas relações são assimétricas, o que significa perdas para os trabalhadores. Além dessas medidas, que incidem de forma danosa nas condições de vida e trabalho da classe trabalhadora, outros aspectos regressivos e polêmicos também estão presentes na nova legislação, como o parcelamento de férias em até três períodos; ${ }^{23}$ a eliminação de

${ }^{23}$ Art. 134 da CLT: "Possibilita, desde que haja concordância do empregado, que as férias possam ser usufruídas em até 3 períodos, sendo que um deles não poderá ser 
remuneração pelo tempo de deslocamento da residência do trabalhador até o posto de trabalho/empresa de difícil acesso (horas in itinere); a prevalência do negociado sobre o legislado; ${ }^{24}$ a não obrigatoriedade do pagamento da contribuição (imposto) sindical, o que acarreta a fragilização do sindicalismo; ${ }^{25}$ a limitação do acesso à Justiça do Trabalho; a permissão do trabalho de gestantes e lactantes em locais insalubres; ${ }^{26}$ a negociação entre trabalhadora e empregador sobre as pausas para a amamentação; a compensação do banco de horas no período máximo de seis meses, conforme acordo individual; e a revogação da obrigatoriedade da presença sindical e/ou de autoridade do Ministério do Trabalho na rescisão de contrato de trabalho vigente há mais de 1 (um) ano, dentre outros elementos que expressam a dilapidação corrosiva dos direitos sociais e do trabalho.

A Contrarreforma Trabalhista brasileira expressa a devastação do alicerce protetivo dos direitos sociais relacionados ao trabalho. Mesmo com um alto índice de rejeição, o governo Michel Temer encaminhou e aprovou pautas impopulares e regressivas que atacam de modo nevrálgico os direitos e a proteção social da classe trabalhadora, violando os

inferior a 14 dias, e os demais não poderão ser inferiores a 5 dias corridos cada um, inclusive para menores de 18 anos e maiores de 50 anos.”

24 “A justificativa apresentada pelo relator do projeto de lei para que a negociação prevaleça sobre a lei é que isso irá promover a 'autonomia coletiva da vontade' e 'dar segurança ao resultado do que foi pactuado entre trabalhadores e empregadores', possibilitando que as partes possam 'negociar a melhor solução para as suas necessidades'. A proposta de Reforma Trabalhista indica 15 itens que podem ser objeto de negociação, mas a redação do artigo que trata do tema inclui o termo 'entre outros' e, com isso, possibilita que outros itens possam ser flexibilizados. Os itens que não podem ser negociados se relacionam ao Artigo $7^{\circ}$ da Constituição Federal, que trata dos direitos trabalhistas” (DIEESE, 2017, p. 15).

25 “Assim, o recolhimento da Contribuição Sindical (mais conhecida como imposto sindical) passa a depender de prévia e expressa autorização dos trabalhadores” (DIEESE, 2017, p. 13).

26 “A empregada gestante ou lactante será afastada de atividades insalubres de grau máximo, mas em grau médio ou mínimo poderá trabalhar, desde que o médico autorize. Caso a empresa não tenha outra ocupação disponível para realocar a trabalhadora, a gravidez será considerada gravidez de risco e ela será afastada do trabalho, recebendo o salário-maternidade durante todo o período” (DIEESE, 2017, p. 11). 
direitos humanos e os princípios fundamentais do direito do trabalho dispostos em legislações, tratados e convenções internacionais. Dentre as falácias e estratégias ideopolíticas que sustentaram a aprovação da Contrarreforma Trabalhista, estavam a necessidade da "modernização das leis trabalhistas” e da "segurança jurídica”, justificando a obsolescência da CLT com as demandas contemporâneas do mundo do trabalho. A Contrarreforma Trabalhista falaciosamente se apresentou como a "panaceia” para a "resolução dos males" do mundo do trabalho e como solução para o problema do desemprego. Isso é essencialmente enganoso, pois o que ocorre com a Contrarreforma Trabalhista é o barateamento dos custos contratuais e trabalhistas que se desdobram em um amplo, profundo e devastador processo de exponenciação de formas precárias e atípicas de trabalho, tendo em vista a lógica de descartabilidade e de banalização do humano-trabalhador. Além do mais, desde a vigência da nova legislação trabalhista, o índice de desemprego no Brasil permanece em expansão.

Nesse contexto de acentuada crise civilizatória, o que se observa é a exposição das fissuras contraditórias postas na relação capital versus trabalho. Sob o ordenamento do neoliberalismo ortodoxo, os direitos e os sistemas de proteção social constituem-se em ameaças, obstáculos e entraves para a reprodução e acumulação ilimitada e irrestrita do capital em sua fase financeira, destrutiva e mundializada.

\section{Considerações finais}

Nas últimas décadas, inúmeras foram as medidas de orientação neoliberal implementadas no sentido do desmonte das bases da proteção social brasileira, o que representa perdas históricas e retrocessos sociais que afetam diretamente o conjunto da população brasileira que vive e sobrevive do trabalho. A condução das medidas neoliberais de austeridade e de ajuste fiscal está integralmente direcionada a atender os interesses do mercado financeiro capitalista, com a consequente liquidação dos direitos e o desmonte corrosivo do sistema de proteção 
social brasileiro, o que resulta em limites e entraves para a expansão da cidadania e da democracia.

Nos últimos anos, sobretudo após 2016, o Brasil vive um período intensificado de retrocessos sociais, diante de uma forte ofensiva conservadora, ultrarreacionária e neoliberal, que afeta e decompõe a proteção social e os direitos trabalhistas conquistados historicamente por meio de lutas e resistências da classe trabalhadora.

São tempos temerosos e temerários de uma crise social, política e econômica, com repercussões nefastas para os avanços sociais e democráticos, tendo em vista a agenda regressiva e polêmica que se expressa com teor conservador e reacionário em diversas ações e projetos aprovados e/ou em tramitação no Congresso Nacional no atual contexto. Entre esses projetos, estão a Lei Antiterrorismo (Lei no 13.260/2016), que criminaliza os movimentos sociais; a aprovação da retirada das expressões “identidade de gênero" e "orientação sexual” da base curricular nacional; a proposta de redução da maioridade penal (PEC n 33/2012); o “Estatuto da Família” (PL n 6.583/2013); o projeto "Escola sem Partido” (PL no 7.180/2014); o projeto da “Cura Gay” (PL n 4931/2016); e o projeto que criminaliza a prática de aborto (PL n 46/2017), dentre outros, que revelam a posição ultrarreacionária e conservadora de uma parte significativa dos parlamentares brasileiros e que são expressão das raízes da formação sócio-histórica brasileira. ${ }^{27}$

O Brasil, um dos países com maior concentração de renda e desigualdade do mundo, atravessa um período de profunda crise política e econômica. Medidas neoliberais de austeridade e ajuste fiscal se intensificaram, contribuindo para a dilapidação dos direitos sociais, afetando duramente a classe trabalhadora.

27 “A nossa formação social nos legou uma classe dominante preconceituosa, mesquinha, egoísta, antidemocrática e violenta. Os traços herdados da escravidão constituíram marcas indeléveis em seu comportamento. A intolerância se volta com frequência contra os negros [...]. Mas essa intolerância racista é também, fundamentalmente, classista. No Brasil, os ricos e seus sócios menores das camadas médias odeiam pobres” (BRAZ, 2017, p. 101-102). 
Diante de um cenário de radicalização e polarização das lutas de classes, implementam-se estratégias dos setores dominantes para assegurar a lógica acumulativa e sanguinária do capital, como é o caso da Contrarreforma Trabalhista, que atinge visceralmente os direitos e a proteção social. Ao adotar de modo irrestrito as formas contratuais baseadas na desregulamentação e na terceirização, o mundo precário do trabalho brasileiro se amplia, o que implica a corrosão dos direitos e a falta de perspectivas protetivas de ingresso no mercado de trabalho.

De acordo com Alves (2014, p. 100), a terceirização é um traço orgânico do capitalismo brasileiro, uma entificação baseada na superexploração da força de trabalho, que articula intensificação do trabalho, prolongamento da jornada laboral e rebaixamento salarial. A terceirização não é a afirmação do arcaico nas relações de trabalho no Brasil, mas a combinação dialética entre o moderno e o arcaico que caracterizou o desenvolvimento capitalista no país.

A Contrarreforma Trabalhista, com seu caráter de inconstitucionalidade, revela a crise civilizatória do tempo presente, tendo em vista as perdas e retrocessos históricos no âmbito da proteção social. O discurso ideopolítico e econômico em defesa da "modernização" da legislação trabalhista se mostra falacioso, tendo em vista o panorama e as consequências que já se apresentam após a aprovação da Contrarreforma, dentre elas o crescimento do desemprego e a intensificação e a precarização do trabalho. Também como consequência desse processo está a responsabilização, culpabilização e penalização de trabalhadores e trabalhadoras pela inserção e posição no mundo do trabalho, desconsiderando as questões conjunturais e estruturais que orientam a sociabilidade regida pelo capital.

Como reação à aprovação da Contrarreforma Trabalhista, que desmonta os direitos sociais e do trabalho, foi apresentada a proposta do Estatuto do Trabalho (Sugestão Legislativa ${ }^{0}$ 12/2018), resultado de amplo debate público e coletivo, envolvendo parlamentares e associações nacionais como a Anamatra (Associação Nacional dos Magistrados da Justiça do Trabalho), a ANPT (Associação Nacional dos Procuradores do Trabalho), a ALJT (Associação Latino-Americana de Juízes 
do Trabalho), a Abrat (Associação Brasileira de Advogados Trabalhistas) e o Sinait (Sindicato Nacional dos Auditores Fiscais do Trabalho), dentre outras entidades ligadas ao mundo do trabalho e representações da sociedade civil e de movimentos sociais.

A proposta do Estatuto do Trabalho, conduzida no Congresso Nacional pelo Senador Paulo Paim (PT-RS), encontra-se em discussão e objetiva regulamentar os artigos $7^{\circ}$ ao 11 da CF/88, de forma a assegurar os princípios e direitos previstos no texto constitucional, revogar a nova legislação trabalhista resultante da contrarreforma aprovada em 2017 e propor medidas comprometidas com a garantia da proteção social da classe trabalhadora brasileira.

Ainda nesse contexto, a vitória eleitoral de Jair Bolsonaro (PSL), que assume a presidência do Brasil a partir de 2019, representa a continuidade das medidas regressivas, de austeridade e de desmonte dos direitos sociais, como é o caso da Contrarreforma da Previdência Social, aprovada em 2019. Outras medidas estão sendo adotadas pelo governo, como os cortes orçamentários nas políticas públicas de educação, dentre outras.

Em um período histórico e conjuntural da realidade brasileira marcado pelo acirramento das lutas de classes, cabe considerar que o encaminhamento de contrarreformas e a aprovação de medidas regressivas não estão ocorrendo sem resistência, mobilização e lutas da classe trabalhadora. Pelo contrário, greves, movimentos e outras formas de reação estão presentes no cotidiano das lutas sociais em todo o país, como as manifestações em defesa da democracia, da universidade e da educação pública, da previdência, da assistência social e da saúde pública, da preservação ambiental e das terras indígenas, dos direitos das mulheres e das populações negra e LGBT. Isso mostra que a história está aberta, constituindo um processo vivo, complexo, contraditório e dinâmico, o que revela a indispensabilidade de uma apreensão crítica e dialética da realidade social. 


\section{Referências}

ALVES, Giovanni. O Minotauro Brasileiro: Reforma Trabalhista e desenvolvimento histórico do capitalismo no Brasil. Revista do Tribunal Regional do Trabalho da 15ª Região, Campinas, n. 51, p. 97-108, 2017.

ALVES, Giovanni. Terceirização e capitalismo no Brasil: um par perfeito. Revista TST, Brasília, v. 80, n. 3, p. 90-105, 2014.

ANTUNES, Ricardo. A sociedade da terceirização total. Revista da ABET, João Pessoa, v. 14, n. 1, p. 6-14, 2015.

ANTUNES, Ricardo. O privilégio da servidão: o novo proletariado de serviços na era digital. São Paulo: Boitempo, 2018.

ARAUJO, Elizeu Serra. As reformas da previdência de FHC e Lula e o sistema brasileiro de proteção social. Revista de Políticas Públicas, São Luís, v. 13, n. 1, p. 31-41, 2009.

BATISTA, Paulo Nogueira. O Consenso de Washington: a visão neoliberal dos problemas latino-americanos. 3. ed. São Paulo: Cartilha Popular, 2001.

BOITO JÚNIOR, Armando. Reforma e crise política no Brasil: Os conflitos de classe nos governos do PT. Campinas: Unicamp/Unesp, 2018. BRAGA, Ruy. O fim do lulismo. In: JINKINGS, Ivana; DORIA, Kim; CLETO, Murilo (org.). Por que gritamos golpe? Para entender o impeachment e a crise política no Brasil. São Paulo: Boitempo, 2016.

BRASIL. [Constituição (1988)]. Constituição da República Federativa do Brasil de 1988. Brasília: Presidência da República, [2016a]. Disponível em: http://www.planalto.gov.br/ccivil_03/constituicao/constituicao. htm. Acesso em: 13 jun. 2018.

BRASIL. Decreto-Lei ${ }^{\circ} 5.452$, de $1^{\circ}$ de maio de 1943. Aprova a Consolidação das Leis do Trabalho. Diário Oficial da União, Rio de Janeiro, 9 ago. 1943. Disponível em: http://www.planalto.gov.br/ccivil_03/ decreto-lei/Del5452.htm. Acesso em: 7 jun. 2018. 
BRASIL. Emenda Constitucional no 95, de 2016. Altera o Ato das Disposições Constitucionais Transitórias, para instituir o Novo Regime Fiscal, e dá outras providências. Diário Oficial da União, Brasília, 16 dez. 2016b. Disponível em: www2.camara.leg.br/legin/fed/emecon/2016/ emendaconstitucional-95-15-dezembro-2016-784029-publicacaooriginal-151558-pl.html. Acesso em: 12 jun. 2018.

BRAZ, Marcelo. O golpe nas ilusões democráticas e a ascensão do conservadorismo reacionário. Revista Serviço Social e Sociedade, São Paulo, n. 128, p. 85-103, 2017.

CAVALCANTI, Bernardo Margulies; VENERIO, Carlos Magno Spricigo. Uma ponte para o futuro? Reflexões sobre a plataforma política do governo Temer. RIL: Revista de Informação Legislativa, Brasília, v. 54, n. 215, p. 139-162, 2017.

DEPARTAMENTO INTERSINDICAL DE ESTATÍSTICA E ESTUDOS SOCIOECONÔMICOS (DIEESE). A Reforma Trabalhista e os impactos para as relações de trabalho no Brasil. Nota Técnica $\mathrm{n}^{\circ} 178$. São Paulo, maio 2017. Disponível em: https://www.dieese.org.br/ notatecnica/2017/notaTec178reformaTrabalhista.pdf. Acesso em: 19 jun. 2018.

DEPARTAMENTO INTERSINDICAL DE ESTATÍSTICA E ESTUDOS SOCIOECONÔMICOS (DIEESE). Balanço das Greves. São Paulo, 2019a. Disponível em: https://www.dieese.org.br/sitio/buscaDirigida?com boBuscaDirigida=TIPO\%7C1352135159121. Acesso em: 18 maio 2020. DEPARTAMENTO INTERSINDICAL DE ESTATÍSTICA E ESTUDOS SOCIOECONÔMICOS (DIEESE). Pesquisa Nacional da Cesta Básica de Alimentos: Salário mínimo nominal e necessário. São Paulo, 2019b. Disponível em: https://www.dieese.org.br/analisecestabasica/ salarioMinimo.html. Acesso em: 19 maio 2020.

FLEURY, Sonia; PINHO, Carlos Eduardo Santos. Liquefação da rede de proteção social no Brasil autoritário. Revista Katálysis, Florianópolis, v. 21, n. 1, p. 14-28, 2018. 
FUNDAÇÃO GETÚLIO VARGAS (FGV). Desigualdade de renda no Brasil bate recorde, aponta levantamento do FGV IBRE. Portal FGV, [s. l.], 22 maio 2019. Disponível em: https://portal.fgv.br/noticias/ desigualdade-renda-brasil-bate-recorde-aponta-levantamento-fgv-ibre. Acesso em: 18 maio 2020.

GALVÃO, Andreia et al. Contribuição crítica à Reforma Trabalhista. Campinas: Unicamp, 2017.

INSTITUTO BRASILEIRO DE GEOGRAFIA E ESTATÍSTICA(IBGE). IBGE divulga as Estimativas de População dos municípios para 2018. Agência IBGE Notícias, [s. l.], 28 ago. 2018. Disponível em: https:// agenciadenoticias.ibge.gov.br/agencia-sala-de-imprensa/2013-agenciade-noticias/releases/22374-ibge-divulga-as-estimativas-de-populacaodos-municipios-para-2018. Acesso em: 18 maio 2020.

INSTITUTO BRASILEIRO DE GEOGRAFIA E ESTATÍSTICA(IBGE). Pesquisa Nacional por Amostra de Domicílios Contínua - PNAD Contínua. Brasília, 2019. Disponível em: https://www.ibge.gov.br/estatisticas/ sociais/trabalho/9173-pesquisa-nacional-por-amostra-de-domicilioscontinua-trimestral.html?=\&t=series-historicas\&utm_source=landing\&utm_ medium=explica\&utm_campaign=desemprego. Acesso em: 18 maio 2020. MARIANO, Cynara Monteiro. Emenda constitucional n ${ }^{\circ}$ 95/2016 e o teto dos gastos públicos: Brasil de volta ao estado de exceção econômico e ao capitalismo do desastre. Revista de Investigações Constitucionais, Curitiba, v. 4, n. 1, p. 259-281, 2017.

MATTOSO, Jorge; POCHMANN, Márcio. Mudanças estruturais e trabalho no Brasil. Economia e Sociedade, Campinas, v. 10, p. 213-43, 1998. PARTIDO DO MOVIMENTO DEMOCRÁTICO BRASILEIRO (PMDB). Uma ponte para o futuro. Brasília: Fundação Ulysses Guimarães, 2015. PINHO, Carlos Eduardo Santos. Emergência e Declínio do Governo Dilma Rousseff à Luz das Capacidades do Estado Brasileiro (20112016). RBPO: Revista Brasileira de Planejamento e Orçamento, Brasília, v. 6, n. 1, p. 94-121, 2016. 
POCHMANN, Márcio. Brasil: segunda grande transformação no trabalho? Estudos Avançados, São Paulo, v. 8, n. 81, p. 23-38, 2014.

POCHMANN, Márcio. Políticas públicas e situação social na primeira década do século XXI. In: SADER, Emir (org.). 10 anos de governos pós-neoliberais no Brasil: Lula e Dilma. Rio de Janeiro: Flacso; Boitempo, 2013.

POCHMANN, Márcio. Traços gerais do movimento de desestruturação do mercado de trabalho brasileiro. Campinas: IE/CESIT, 1997. SINGER, André. Cutucando onças com varas curtas: o ensaio desenvolvimentista no primeiro mandato de Dilma Rousseff (2011-2014). Novos Estudos Cebrap, São Paulo, n. 102, p. 39-67, 2015. 


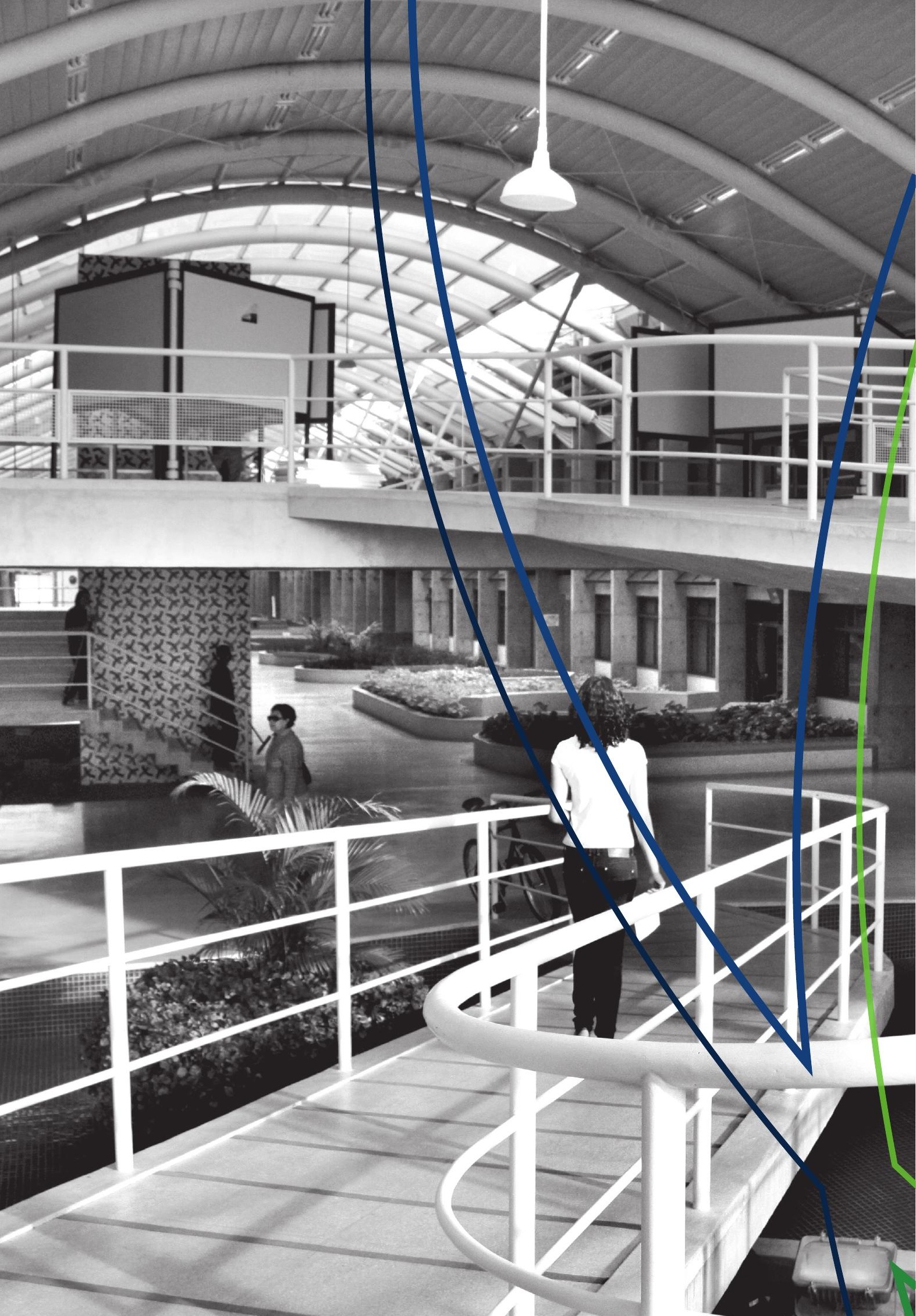


Capítulo 2

\title{
Classe
}

trabalhadora, novo sindicalismo e autoemancipação

\author{
Michelly Ferreira Monteiro Elias \\ Universidade de Brasília (UnB) \\ michellyelias@unb.br
}

\section{Introdução}

Este texto reflete sobre alguns dos principais enfrentamentos da classe trabalhadora brasileira no contexto do desafio histórico da sua autoemancipação, a partir da experiência do novo sindicalismo das décadas de 1970 e 1980.

As reflexões aqui apresentadas são parte dos estudos desenvolvidos durante pesquisa de tese de doutorado realizada entre 2014 e 2018.

Os estudos conduzidos nesse percurso, sobre os fundamentos da teoria da revolução em Marx e sobre as particularidades da formação social brasileira, nos levaram à constatação de que a teoria da revolução em Marx, que aponta a possibilidade histórica da autoemancipação da classe trabalhadora na sociedade burguesa, permanece atual, possuindo 
uma relação dialética com as suas experiências de luta. Frente à complexidade alcançada pelas lutas de classes na fase imperialista do capital, principalmente desde o início da reestruturação produtiva em nível internacional, essa classe tem enfrentado desafios cada vez mais complexos e difíceis acerca desse processo histórico.

No que se refere à formação social brasileira, o modo de produção capitalista e as classes sociais fundamentais, assim como suas frações de classe, adquiriram características particulares, determinadas pela divisão internacional do trabalho e pela economia de caráter dependente, adensando, principalmente desde a constituição do capitalismo monopolista no país, os desafios para as lutas da classe trabalhadora brasileira com vistas à sua autoemancipação. As contradições geradas pela consolidação do capitalismo monopolista no Brasil durante a ditadura civil-militar, o aprofundamento da condição de superexploração da classe trabalhadora nesse período, a intensificação das lutas de classes desde a década de 1950 e a perda de hegemonia dos comunistas no movimento sindical desde o início da década de 1960 possibilitaram o advento do novo sindicalismo durante as décadas de 1970 e 1980 no país.

A partir desses elementos, foi possível identificar o novo sindicalismo como um processo que, no contexto da formação social brasileira e frente ao histórico das lutas da classe trabalhadora no país, foi síntese de alguns dos principais desafios a serem enfrentados ao longo do seu processo de autoemancipação. Visando identificar esses desafios, abordamos as análises de alguns dos principais estudiosos do movimento sindical no Brasil sobre o novo sindicalismo, que se situam no âmbito da tradição marxista ${ }^{1}$ e que apontam questões fundamentais para refletirmos

1 Em relação à tradição marxista, baseamo-nos em Netto (1994, p. 76-77), que afirma: “A obra de Marx fundou um modo original de pensar a sociedade burguesa e a sua dinâmica, que inclui necessariamente a alternativa da revolução socialista. Tendo como marco o pensamento marxiano, desenvolveu-se uma tradição marxista, dos anos 80 do século passado aos nossos dias. No bojo desta tradição se entrecruzaram e se entrecruzam propostas diversificadas, conquistando alternadamente a hegemonia no interior desse leito histórico graças a razões diversas (desde o seu apelo intelectual à sua funcionalidade política). Respondendo, bem ou mal, aos desafios históricos em face dos quais se foram erigindo, tais propostas tanto alargaram o universo temático 
sobre as suas principais características frente ao desafio histórico da autoemancipação da classe trabalhadora brasileira.

Para identificarmos esses estudiosos diante da ampla e rica literatura sobre o novo sindicalismo no Brasil, definimos a produção bibliográfica de autores da tradição marxista sobre o tema, uma vez que essa perspectiva teórica - apesar das diferenças de análises existentes no seu interior - tem como elemento comum a reflexão sob o horizonte da transformação social e do socialismo.

Posteriormente, dentre a bibliografia levantada com base nesse critério, identificamos obras que trouxessem, mais especificamente e de forma diferenciada, questões acerca das principais características do novo sindicalismo que pudessem contribuir para nossa análise sobre o seu significado político para as lutas da classe trabalhadora brasileira com vistas à sua autoemancipação. Assim, buscamos identificar estudos que apontassem elementos para entendermos em que medida o novo sindicalismo, enquanto experiência de luta, contribuiu para a formação da classe trabalhadora brasileira como classe potencialmente revolucionária da sociedade burguesa.

Nessa perspectiva, e frente à diversa produção bibliográfica existente de autores de tradição marxista sobre o novo sindicalismo, nos detivemos nos estudos de Antunes (1988), Boito Júnior (1991), Frederico (1979; 1991; 1994; 2014) e Santana (1999; 2003; 2017).

Diante disso, apresentamos, no presente texto, uma síntese das principais características do novo sindicalismo com base nesses estudiosos. Em seguida, indicamos algumas reflexões sobre o significado político dessa experiência de luta e apontamos alguns dos seus principais desafios vivenciados, considerando-a como um processo que, no contexto da formação social brasileira e frente ao histórico das lutas da classe

da tradição marxista quanto se vincularam seletivamente a algumas dimensões do pensamento de Marx. Em poucas palavras: a obra de Marx (que chamamos de marxiana) forneceu a base para inúmeros desenvolvimentos (as correntes marxistas) que, no seio de um bloco teórico-cultural diferenciado (a tradição marxista), oferecem tratamentos complementares, alternativos e/ou excludentes para os problemas que se foram e vão colocando no mundo burguês e nas suas ultrapassagens revolucionárias.” 
trabalhadora no país, foi síntese de alguns dos principais enfrentamentos dessa classe ao longo do desafio histórico da sua autoemancipação.

\section{O avanço das lutas da classe trabalhadora no período de esgotamento da ditadura civil-militar e a formação do novo sindicalismo}

Durante a fase de consolidação do capitalismo monopolista no Brasil, a ditadura civil-militar aprofundou a economia dependente, sustentada na superexploração $o^{2}$ da classe trabalhadora; manteve a cidadania de caráter historicamente restrito, instituída no país desde o começo do século XX; e consolidou o Estado como um meio praticamente exclusivo da dominação burguesa. Associado a isso, a partir do início do capitalismo monopolista, durante a década de 1950, as lutas de classes vinham adquirindo a sua expressão mais complexa e acirrada no país, tendo como ápice desse processo o período da década de 1970

2 Segundo Marini (2005), em países de economia dependente como o Brasil, a dinâmica de exploração do trabalho assalariado foi se estabelecendo de forma que parte da mais-valia produzida também precisava ser repassada para os países de economia central, e, como forma de compensar essa perda, as classes dominantes brasileiras foram criando diversos mecanismos de extração da mais-valia, submetendo os(as) trabalhadores(as) a uma condição de “maior exploração" - situação caracterizada não pelo desenvolvimento da sua capacidade produtiva, mas pela intensificação do trabalho, pelo prolongamento da jornada de trabalho e pela constante diminuição da média salarial, estabelecida em conexão com o rebaixamento da média de bens necessários à sobrevivência da classe trabalhadora. Essa condição, associada à predominância do baixo nível de desenvolvimento das forças produtivas e ao tipo das principais atividades econômicas desenvolvidas no país - como a agricultura latifundiária, a mineração, a produção industrial voltada para a exportação - estabeleceu uma condição de superexploração em que o grau de exploração do trabalho - que é intrínseco a qualquer relação salarial no modo de produção capitalista - tornou-se maior devido ao fato de que "são negadas ao trabalhador as condições necessárias para repor o desgaste de sua força de trabalho [...] porque lhe é obrigado um dispêndio de força de trabalho superior ao que deveria proporcionar normalmente, provocando assim seu esgotamento prematuro [...] porque lhe é retirada inclusive a possibilidade de consumo do estritamente indispensável para conservar sua força de trabalho em estado normal” (MARINI, 2005, p. 156-157). 
- realidade que possibilitou o surgimento e o desenvolvimento do novo sindicalismo entre o final dessa década e a de 1980.

O novo sindicalismo foi o processo que se iniciou com as greves dos anos de 1978 a 1980, em que se destacou a atuação dos sindicatos do ABC paulista, os quais, ao organizarem lutas e reivindicações sob o protagonismo das suas bases, passaram a exercer significativa influência no conjunto do movimento sindical, enfrentando a política de arrocho salarial e a legislação antigreve vigente na época. Questionavam, assim, a política econômica empreendida pelo regime ditatorial, que tinha como principal base de sustentação a superexploração da classe trabalhadora. Dessa maneira, tais lutas se expandiram para diversas categorias de trabalhadores e adquiriram abrangência nacional, associadas às contestações acerca da estrutura sindical e da atuação repressora do Estado.

Assim, o novo sindicalismo caracterizou-se pela crítica à estrutura sindical e pela mobilização das bases por meio de contínuas ações grevistas, na perspectiva da conscientização da classe trabalhadora. Além disso, associou-se às lutas dos(as) trabalhadores(as) rurais e dos movimentos sociais de caráter popular, defendendo a realização de reformas sociais e as lutas democráticas, o que possibilitou sua capilaridade para diferentes segmentos da classe trabalhadora e seu vínculo com os segmentos populares.

Esses aspectos, associados à continuidade do movimento grevista durante a década de 1980 - apesar da dura repressão estatal e da diminuição do número total de greves no ano de 1980 - e a avanços organizativos como a fundação do Partido dos Trabalhadores (PT) em 1980, da Articulação Nacional dos Movimentos Populares e Sindicais (Anampos) em 1982, da Central Única dos Trabalhadores (CUT) em 1983 e de grupos como o Movimento dos Trabalhadores Rurais Sem Terra (MST) em 1984 propiciaram o avanço não só do movimento sindical, mas das lutas da classe trabalhadora de uma forma geral durante a década de 1980.

Esse avanço se expressou por meio da realização de importantes greves por categorias entre 1983 e 1985, de greves com a ocupação de fábricas e de quatro greves gerais entre 1986 e 1989. Além disso, o 
movimento sindical teve um significativo papel no final da década de 1980 para a retomada do regime democrático, exercendo tensão por meio de mobilizações, organizando-se e atuando durante a Assembleia Constituinte de 1988/89 para que os direitos da classe trabalhadora fossem expandidos e regulamentados pela Constituição Federal de 1988 (CF/88).

Tais acontecimentos demonstravam a dimensão generalizante que essas lutas foram adquirindo naquela época, sendo um importante exemplo disso o total de 3.943 greves que chegaram a ocorrer no país no ano de 1989, conforme afirma Badaró (2009).

A partir desses elementos, temos como referência esse contexto e ao mesmo tempo as dificuldades objetivas e subjetivas que a classe trabalhadora foi enfrentando historicamente no terreno das lutas de classes, desde a sua formação inicial até a consolidação do capitalismo monopolista no país, em que identificamos a importância da experiência do novo sindicalismo para as lutas dessa classe.

Ademais, o novo sindicalismo conformou, durante a década de 1980, um campo político de caráter democrático e popular, juntamente com o sindicalismo rural e os movimentos sociais populares, participando das lutas por reforma agrária, pela saúde pública, por moradia, pela suspensão dos pagamentos da dívida externa, pelo direito à participação política e pela democracia, associando-as a uma perspectiva de luta classista e tendo a classe trabalhadora como protagonista desse processo.

Diante disso, chamamos a atenção para uma particularidade das lutas no período dos anos 1980, que foi a atuação e o caráter popular dos movimentos sociais, no sentido de tensionarem o padrão de desenvolvimento do capitalismo brasileiro ao reivindicarem direitos historicamente negligenciados e reformas que alteravam a lógica de distribuição da riqueza e da renda no país. Nessa perspectiva, as lutas desses movimentos contribuíram de forma significativa para que, naquele contexto de luta pela democracia, o novo sindicalismo e as organizações a ele ligadas ampliassem a sua força social para além do segmento sindical e para que a classe trabalhadora incidisse na dinâmica das lutas de classes, em defesa das suas necessidades e interesses.

Embora a regulamentação dos direitos trabalhistas e de cidadania na CF/88 não tenha atendido em sua plenitude a todas as demandas e 
reivindicações da classe trabalhadora, e apesar de tal regulamentação não ter significado a concretização de todos os direitos regulamentados, essa conquista não deixou de ser um marco importante para as lutas pelos direitos da classe trabalhadora no Brasil, uma vez que esses direitos foram historicamente restringidos e negligenciados - ao tempo em que, quando implantados, foram muitas vezes utilizados como parte da estratégia de dominação política e ideológica exercida pelo Estado e pelas classes dominantes sobre a classe trabalhadora.

Dessa maneira, não estamos deixando de ver que, diante do desafio histórico da autoemancipação da classe trabalhadora, a luta e a regulamentação por direitos se situa, em essência, na esfera da emancipação política que se restringe aos marcos da sociedade burguesa, conforme constatado por Marx em A questão judaica. ${ }^{3}$ Contudo, o que ressaltamos aqui é que, no contexto da formação social brasileira, as lutas sindicais e por determinados direitos e reformas adquiriram um caráter questionador do modelo de exploração e dominação predominante, que se constituiu marcado por um capitalismo de tipo dependente, ${ }^{4}$ com base na superexploração da classe trabalhadora e em formas autocráticas de dominação por parte das classes dominantes. Também apontamos que tais lutas, quando associadas a experiências de mobilização, reivindicação e organização que levam a embates e disputas com essas classes, contribuem

3 Nesse texto, o autor aponta que os direitos de cidadania se tornaram um meio para a preservação dos direitos do homem egoísta e afirma que a separação existente entre o gênero e o indivíduo, o coletivo e o individual, o Estado e a sociedade civil, fazem parte da constituição dos limites da emancipação política da sociedade burguesa, formando o cidadão apenas em seu sentido abstrato, uma vez que "os libertadores políticos reduzem a cidadania, a comunidade política, a simples meio para preservar os chamados direitos do homem; [...]” (MARX, [1843] 1993, p. 58).

4 Segundo Marini (2005, p. 141), o capitalismo de tipo dependente se estabelece a partir de uma relação de subordinação entre nações formalmente independentes, em cujo marco as relações de produção das nações subordinadas são modificadas ou recriadas para assegurar a reprodução ampliada da dependência. A consequência da dependência não pode ser, portanto, nada mais do que maior dependência, e sua superação supõe necessariamente a supressão das relações de produção nela envolvidas. 
para a formação da classe trabalhadora no seu sentido político, ou seja, enquanto classe potencialmente revolucionária da sociedade burguesa.

Com isso, a partir da experiência do novo sindicalismo e da força social que este conseguiu acumular durante a década de 1980, vemos a potencialidade política que a luta sindical pelos direitos de cidadania e por reformas como a agrária e a urbana adquiriram naquele contexto, ao se associarem às mobilizações, greves e experiências organizativas da classe trabalhadora. Por isso, entendemos que, apesar das suas contradições e limites, o novo sindicalismo se caracterizou, naquele período, por defender os interesses e os direitos da classe trabalhadora e dos segmentos populares e por estabelecer uma significativa dinâmica de mobilização e organização da classe diante de tais circunstâncias.

Tendo como referência o histórico das lutas da classe trabalhadora na formação social brasileira e as principais contradições geradas pela consolidação do capitalismo monopolista no país no âmbito das lutas de classes, o novo sindicalismo foi um processo de lutas e mobilizações sindicais - que teve como protagonista o movimento sindical do ABC paulista, com destaque para o Sindicato dos Metalúrgicos de São Bernardo do Campo - ocorrido entre o final dos anos 1970 e a década de 1980, e que se associou às reivindicações de caráter democrático e popular, adquirindo uma feição classista.

Nessa perspectiva, Antunes (2011) coloca:

O patamar atingido pela luta de classes no Brasil naquela década esteve entre os mais significativos em todo o mundo capitalista. Ao longo da década de 1980, houve um quadro nitidamente favorável ao novo sindicalismo no Brasil (enquanto movimento social dos trabalhadores, com forte caráter de classe), que caminhava em direção contrária ao quadro de crise sindical já presente em vários países capitalistas avançados. (ANTUNES, 2011, p. 139).

Dessa forma, as lutas que referenciamos dizem respeito ao processo iniciado com o movimento grevista de 1978 a 1980, que estabeleceu uma ampla dinâmica de mobilização da classe trabalhadora por meio da 
luta sindical durante a década de 1980 e que, ao constituir uma perspectiva classista, atuou de forma predominante - porém, não homogênea - nesse período para que a luta e a organização sindical fossem formas de unificação da classe trabalhadora e de fortalecimento da luta pelo socialismo. Por isso, identificamos que o novo sindicalismo teve um significado político para as lutas da classe trabalhadora brasileira com vistas ao seu desafio histórico da autoemancipação.

Considerando esses elementos, temos como referência histórica que o contexto estabelecido desde o início da década de 1990 e posterior à "redemocratização do país, com a aprovação da CF/88 e as eleições presidenciais de 1989, encerra, em certo sentido, a 'era' do novo sindicalismo brasileiro” (BADARÓ, 2009, p. 125).

Essa ponderação se faz necessária porque, após o final da década de 1980, houve significativas mudanças políticas e ideológicas nas principais organizações fundadas enquanto parte desse processo do novo sindicalismo, a exemplo do PT e da Central Única dos Trabalhadores (CUT).

Tais mudanças, diante das particularidades da formação social brasileira e do histórico de superexploração da classe trabalhadora, foram condicionadas pelo contexto internacional de crise terminal do movimento comunista no final da década de 1980 e pelo início da ofensiva neoliberal e da reestruturação produtiva desde o início dos anos 990 no Brasil. ${ }^{5}$ Esses determinantes, associados dialeticamente em suas dimensões históricas e conjunturais, alteraram a composição da classe trabalhadora e a dinâmica das lutas no país, afetando as lutas de caráter classista, e dentre elas, em particular, os rumos do novo sindicalismo.

Nesse sentido, é necessário contextualizar que as mudanças políticas e ideológicas que ocorreram desde esse período no âmbito da CUT - que se tornou a principal central sindical do país - se deram frente a esses determinantes, os quais traçaram uma difícil e complexa realidade

\footnotetext{
5 No contexto das particularidades da formação social brasileira, a ofensiva neoliberal se expandiu no Brasil, causando desde o início dos anos 1990 profundas mudanças na organização do sistema produtivo e da força de trabalho, assim como na caracterização da classe trabalhadora e no papel do Estado, dificultando sobremaneira as lutas dessa classe, principalmente as de caráter classista e revolucionário.
} 
para as lutas da classe trabalhadora no Brasil. Em relação ao movimento sindical, esse processo dificultou as condições para a mobilização e organização em virtude das novas formas de ordenamento do sistema produtivo, de emprego e de gestão da força de trabalho, juntamente com a permanência da estrutura sindical corporativista ${ }^{6}$ e a constituição e fortalecimento de um sindicalismo de caráter neoliberal e conservador, que fundou a Força Sindical em $1991 .^{7}$

Ao considerarmos esses elementos, identificamos que as mudanças ocorridas na ação da CUT no decorrer da década de 1990 se deram de forma inter-relacionada com a dinâmica geral das lutas da classe trabalhadora e do movimento sindical que foram determinados por essa realidade.

Dentre as mudanças que passaram a permear a atuação da Central, podemos destacar a diminuição da participação das bases e de

6 Sobre essa questão, Badaró (2009, p. 132) coloca: “Em relação às propostas apresentadas pelo novo sindicalismo nos anos de 1980, o projeto de uma mudança da estrutura sindical, em direção à autonomia e liberdade plena de organização, foi frustrado. Como vimos, a Constituição de 1988 garantiu o direito de organização dos funcionários públicos, sacramentou a possibilidade de criação de centrais sindicais e, a conquista mais importante, extinguiu o poder de intervenção do Ministério do Trabalho sobre os sindicatos. No entanto, permaneceram a unicidade sindical, o monopólio de representação, o poder normativo da Justiça do Trabalho e o imposto sindical. Ou seja, mantiveram-se as bases fundamentais da estrutura sindical corporativista.”

7 A Força Sindical atua, desde a sua fundação, de forma totalmente baseada na estrutura sindical, exercendo, de maneira predominante, uma prática permeada pela burocratização, pela pouca representatividade e participação das bases e pelo vínculo com o conservadorismo político que beneficia as classes dominantes. Além disso, tem a perspectiva de exaltar o poder econômico e os limites da luta sindical frente a isso; de defender a negociação e a conciliação sistemática entre sindicatos e empresas, com o objetivo de adequar os interesses de ambos; de entender que a luta sindical não deve estar associada à luta política e que os sindicatos devem primar por ações práticas que resultem em melhorias das condições de trabalho e no aumento da produtividade das empresas; de apoiar a concepção de que o Estado deve reduzir suas ações no campo econômico e privatizar as grandes empresas como forma de incentivar a geração de empregos. Conforme Santana (2017, p. 300), a Força Sindical “foi constituída por setores do chamado 'sindicalismo de resultados', egressos da CGT, e que tinham como política clara rivalizar com a CUT, a qual já havia se tornado hegemônica no movimento sindical nacional, comandando o que seria, em seu conjunto, a fatia mais importante e representativa das organizações de trabalhadores.” 
diversas categorias da classe trabalhadora na luta sindical, determinada pelas mudanças na sua caracterização, em que houve a diminuição do proletariado industrial, a desconcentração das unidades produtivas, a contínua perda dos direitos sociais e trabalhistas e o aumento da instabilidade nos empregos por meio da rotatividade e da terceirização, assim como o aumento da concorrência por emprego no interior da própria classe (ANTUNES, 2010).

Ao mesmo tempo, a própria CUT realizou mudanças em relação à sua organização interna, no sentido de diminuir o peso da participação das bases e das oposições em suas definições e fortalecer o papel das direções. Tais mudanças se deram principalmente por meio da criação de federações e confederações que passaram a ser representadas, exclusivamente, tanto do ponto de vista político quanto jurídico, pela direção da CUT. Junto a isso, as alterações internas que ocorreram diante do contexto estabelecido desde o início da década de 1990, ao tempo em que se consolidava a sua inserção na estrutura sindical, fizeram com que a Central passasse a ter significativa influência da perspectiva socialdemocrata, ${ }^{8}$ principalmente desde o seu $4^{\circ}$ Congresso, ocorrido em 1991.

Com a concomitância desses elementos, a CUT passou por um processo que levou a uma atuação sindical baseada na perspectiva de manutenção dos direitos historicamente conquistados pela classe trabalhadora, privilegiando a negociação das demandas corporativas e a participação nas decisões das políticas setoriais. Exemplo disso foi que ela passou a defender propostas acerca do desenvolvimento de uma política industrial mais justa socialmente, por meio de uma atuação sindical sem confrontos diretos e com um horizonte propositivo.

É possível localizar, em vários episódios dos anos de 1990, manifestações típicas dessa virada na postura de sindicatos e sindicalistas identificados com a CUT. Como nos acordos fechados no ABC paulista, desde a segunda

8 Em 1992, a CUT se filia à Cisol (Central Sindical Internacional), ligada ao sindicalismo estadunidense e socialdemocrata europeu. 
metade dos anos de 1990, entre o Sindicato dos Metalúrgicos e as grandes montadoras de automóveis, sob o peso das ameaças de demissão. Lá, no berço do novo sindicalismo, o sindicato acabou por fechar acordos em que aceitou: ampliação do controle empresarial sobre a jornada de trabalho (via ampliação das horas extras não remuneradas - "banco de horas"); redução de salários (primeiro indireta, depois direta) e política de incentivo às demissões e fechamento de postos (via planos de demissão voluntária). (BADARÓ, 2009, p. 139-140).

Respaldado cada vez menos em uma perspectiva de classe, o movimento sindical, herdeiro do novo sindicalismo, foi se atrelando a uma dinâmica de burocratização e institucionalização em que, diante do avanço da ofensiva neoliberal da década de 1990, principalmente durante os governos de Fernando Henrique Cardoso, entre 1995 e 2002, as lutas foram adquirindo um caráter predominantemente defensivo e imediato.

Entretanto, é importante colocar que, apesar dessas mudanças políticas e ideológicas ocorridas na CUT no decorrer da década de 1990, durante a primeira metade dessa década houve a manutenção de diversas ações de luta e resistência por parte da classe trabalhadora e do movimento sindical.

Em relação a isso, Santana (2017) aponta que houve a organização da greve geral de 1990 por parte da CUT e da Central Geral dos Trabalhadores (CGT), reivindicando uma política salarial mais justa, e a realização de diversas greves por segmentos, como as dos petroleiros, dos operários da Ford e dos eletricitários naquele mesmo ano, além da greve dos portuários em 1992, que paralisou 40 mil trabalhadores(as) em 35 portos do país e de outras greves ocorridas em 1995, como a histórica greve organizada pela Federação Única dos Petroleiros (FUP), filiada à CUT.

Essa greve dos petroleiros teve como principais objetivos a reposição de perdas salariais e o protesto contra o fim do monopólio estatal do petróleo, contando com a adesão de $90 \%$ da categoria, que paralisou dez refinarias no país. Porém, quando o governo de Fernando Henrique Cardoso reconheceu que, diante daquela conjuntura, 
"era necessário dobrar a espinha dorsal de seu principal opositor, o sindicalismo, principalmente aquele ligado à CUT” (SANTANA, 2017, p. 302), a greve enfrentou diversas ações de criminalização, boicote, isolamento e repressão, que incluíram o envio de tropas do exército a quatro das refinarias paralisadas. Dessa forma, após 32 dias de duração, a greve foi suspensa sem nenhuma das reivindicações atendidas, adquirindo um significado de grande derrota do movimento sindical frente a um governo que empreendia a ofensiva neoliberal no país. O seu desfecho foi "um divisor de águas na história do movimento sindical no período. Com ela tivemos um ponto de inflexão política para o movimento sindical nacional, que se agravaria ainda mais com o avançar das transformações econômicas” (SANTANA, 2017, p. 303).

Assim, foi diante dessa realidade de meados da década de 1990, juntamente com os elementos anteriormente mencionados, que se estabeleceu a crise do movimento sindical e as mudanças políticas e ideológicas por parte da CUT. Tal situação levou a uma fragilidade cada vez maior da estratégia de associar as lutas sindicais e populares aos interesses históricos da classe trabalhadora e a um projeto de caráter socialista - estratégia essa que tinha orientado a trajetória de fundação da CUT em 1983 e esteve presente em sua forma de atuação e organização até o final da década de 1980.

\section{O significado político do novo sindicalismo para as lutas da classe trabalhadora brasileira}

Diante desses breves elementos que marcaram a experiência do novo sindicalismo até o início da ofensiva neoliberal e da reestruturação produtiva no Brasil, observamos que esse período, a partir da década de 1990, caracterizou-se pelo início de uma crise do movimento sindical, associada a mudanças políticas ocorridas durante a trajetória do PT e que interferiram na composição da esquerda como um todo, tendo profundas consequências até os dias atuais para as lutas da classe trabalhadora no país. 
Porém, frente às particularidades da formação social brasileira e ao histórico das lutas da classe trabalhadora no país, entendemos que esses acontecimentos, que se deram durante a década de 1990, não anularam a importância e o significado do que foi o novo sindicalismo. Por isso, diante de todos os elementos que o caracterizaram, consideramos que ele foi síntese de alguns dos principais enfrentamentos da classe trabalhadora brasileira no contexto do desafio histórico da sua autoemancipação.

Assim, ao identificarmos elementos que demonstram o significado político dessa experiência de luta, destacamos que todos os estudos analisados para a realização deste trabalho - Antunes (1988), Boito Júnior (1991), Frederico (1979; 1991; 1994; 2014) e Santana (1999; 2003; 2017) - apontam que as greves de 1978 a 1980, que deram início ao novo sindicalismo, tiveram um caráter de luta de massas com viés espontâneo, demonstrando a capacidade de resistência das bases operárias após a intensificação da condição de superexploração vivenciada pela classe trabalhadora, juntamente com a sistemática repressão empreendida pelo regime ditatorial.

Dessa maneira, na medida em que esse movimento grevista se concretizou, adquiriu um caráter político ao questionar a lei antigreve e a política de arrocho salarial enquanto pilar da política econômica consolidada pela ditadura, contestando assim a condição de superexploração da classe trabalhadora. Junto a isso, deu início a um processo de lutas e mobilizações que se tornou um marco histórico para o movimento sindical e para as lutas da classe trabalhadora brasileira.

Sublinhamos que, apesar das diferentes análises por parte dos estudiosos do movimento sindical supracitados em relação à conceituação e caracterização do novo sindicalismo, em que apontam reflexões e problemáticas diferenciadas, identificando limites e possibilidades, o elemento comum a todos é no sentido de reconhecerem que o período entre 1978 e 1989 - em que pese, inclusive, as problematizações sobre a denominação ter sido ou não um novo sindicalismo - foi o de maior avanço para as lutas da classe trabalhadora no Brasil.

Com base nos estudos desses autores, identificamos, como uma primeira característica que particularizou o novo sindicalismo, o protagonismo 
exercido pelo operariado fabril - a exemplo dos metalúrgicos do $\mathrm{ABC}$ paulista -, que havia se expandido durante a consolidação do capitalismo monopolista no país.

Tendo como referência o histórico de formação da classe trabalhadora brasileira, observa-se que o modelo econômico consolidado durante a ditadura civil-militar potencializou a constituição desse operariado, o qual se concentrou principalmente na região metropolitana de São Paulo, trabalhando nos setores modernos da economia que eram a base do sistema industrial. Além de ter se expandido numericamente, esse segmento, embora não deixasse de possuir características historicamente vivenciadas pela classe trabalhadora - como a condição de superexploração e o acesso restrito aos direitos de cidadania - diferenciou-se pela importância do papel e a função econômica que exercia no sistema produtivo na época e pela disposição em realizar lutas corporativas de forma espontânea e não atrelada à estrutura sindical, já que não havia se formado tendo essa estrutura como referência para suas lutas e reivindicações.

Além disso, identificamos que esse protagonismo se deu juntamente com a mobilização de outros segmentos da classe trabalhadora, mostrando, de forma dialética, tanto a centralidade que o operariado teve naquele contexto de acirramento das lutas de classes quanto a importância que os demais segmentos da classe trabalhadora tiveram para que a luta sindical se expandisse e se fortalecesse.

Associado a isso, a segunda característica do novo sindicalismo que apontamos com base nos autores analisados é o fato de este ter-se constituído como um movimento de massas que fomentou amplas mobilizações, conseguindo fazer com que as greves se tornassem efetivamente meios de disputas e embates frente à sua classe antagônica. Ao entendermos as greves como um instrumento de luta e não como um fim em si, observamos que o novo sindicalismo conseguiu fazer uso delas de forma atrelada aos objetivos das suas lutas corporativas e usá-las num contexto de acirramento das lutas de classes, como um mecanismo de pressão e de questionamento do modelo de exploração e dominação estabelecido. Dessa forma, as greves daquele contexto 
foram fundamentais para que houvesse um processo - permeado por contradições, avanços e retrocessos - de formação da classe trabalhadora, no sentido de se forjar por meio do reconhecimento, da defesa e da luta por suas necessidades e interesses.

A terceira característica que também foi possível identificar é que o novo sindicalismo desenvolveu, mediante os movimentos grevistas, experiências organizativas desde as bases, a exemplo da organização de comissões, comandos, núcleos e setores, assim como a realização de grandes assembleias no decorrer das greves e posteriormente a elas, visando manter diferentes segmentos da classe trabalhadora mobilizados. Essas experiências, juntamente com a fundação da CUT enquanto central sindical vinculada à perspectiva política e ideológica do novo sindicalismo e ligada desde a sua formação inicial ao PT, contribuíram para avanços da luta sindical e para a expansão de experiências organizativas da classe trabalhadora, que foi vivenciando com isso inúmeros desafios no âmbito da sua organização.

A quarta característica que particularizou o novo sindicalismo foi a de que este se articulou às lutas dos movimentos sociais de caráter popular, apoiando e integrando as reivindicações por reforma agrária e urbana, pela saúde pública, pelos direitos das mulheres e por igualdade racial, dentre outros - além de ter construído espaços de articulação e mobilização conjunta com esses movimentos, a exemplo da Articulação Nacional dos Movimentos Populares e Sindicais (Anampos), que se tornou decisiva para a própria fundação da CUT.

Apesar das polêmicas que a relação entre esses movimentos causou na época, uma vez que os demais segmentos da esquerda, como a Unidade Sindical, entendiam que o protagonismo deveria ser exclusivamente do movimento sindical, o que se viu foi que essa articulação fortaleceu as lutas da classe trabalhadora. Historicamente, as demandas dos movimentos sociais de caráter popular tinham adquirido uma dimensão questionadora do padrão de acumulação capitalista estabelecido no Brasil e, por isso, a articulação estabelecida entre esses e o movimento sindical proporcionou avanços em relação à defesa dos direitos da classe trabalhadora durante a transição democrática. 
Nesse sentido, a quinta característica que apontamos é a de que o novo sindicalismo, enquanto movimento sindical, constituiu força social própria ao desenvolver lutas e mobilizações para além do domínio da estrutura sindical corporativista. Nesse sentido, entendemos que essa força se manteve como um determinante que permeou toda a atuação do novo sindicalismo, mas a crítica à estrutura sindical, juntamente com a realização de ações independentes das normas impostas e dos sindicatos cooptados, propiciou a sua expansão e capilaridade tanto no operariado fabril quanto em demais segmentos da classe trabalhadora. Esse processo, associado às mobilizações, à expansão do movimento grevista, às experiências organizativas desenvolvidas e à articulação com os movimentos sociais de caráter popular, proporcionou-lhe força social própria.

Dessa forma, apontamos que foi a partir desse acúmulo de forças que o novo sindicalismo e o campo político a ele associado desenvolveram capacidade de incidência na conjuntura política da época, impondo limites à hegemonia exercida pelas classes dominantes durante a transição democrática e contribuindo para a regulamentação de direitos que possibilitavam a ampliação do regime democrático.

Assim, a sexta característica que identificamos acerca do novo sindicalismo foi a de que ele desenvolveu a luta sindical sob uma perspectiva política de mobilização e conscientização da classe trabalhadora. Apesar das dificuldades e polêmicas vivenciadas durante a década de 1980 no movimento sindical e na esquerda como um todo, principalmente em torno da relação entre luta econômica e política, sobre formas de organização de classe, método de atuação e análise de conjuntura, a sua atuação se caracterizou fundamentalmente pela concepção de que as lutas da classe trabalhadora deveriam ser dirigidas pela própria classe, visando a sua unidade e a conquista dos seus objetivos imediatos e históricos no sentido da construção de uma sociedade sem exploração.

Por isso, entendemos que, juntamente com a construção de um movimento sindical baseado na democracia, na autonomia, na participação das bases e na realização sistemática de mobilizações, o novo sindicalismo constituiu uma atuação que tinha como horizonte uma 
estratégia de viés classista que esteve presente nas suas reivindicações e na sua forma de atuação e organização até o final da década de 1980.

Assim, a partir dessas características é que situamos o significado político que o novo sindicalismo teve para as lutas da classe trabalhadora brasileira com vistas à sua autoemancipação, além das diversas questões que o envolveram como uma experiência de luta que contribuiu para a sua formação enquanto classe potencialmente revolucionária da sociedade burguesa.

Tendo como referência a trajetória do novo sindicalismo, constata-se o desafio que está colocado para a construção de lutas concretas por parte da classe trabalhadora em uma sociedade que historicamente impõe, de forma geral e ao mesmo tempo particular, uma realidade que, sob a hegemonia da sua classe antagônica, se torna cada vez mais difícil e complexa do ponto de vista econômico, político e social - realidade cujos desdobramentos mais perversos a classe trabalhadora enfrenta de diferentes formas em seu cotidiano.

Portanto, ao identificarmos o significado político do novo sindicalismo por meio dessas características, concebemos que esse processo se deu permeado por inúmeras contradições e desafios, os quais, a nosso ver, são síntese de alguns dos principais desafios a serem enfrentados pela classe trabalhadora brasileira no contexto da sua autoemancipação.

\section{O novo sindicalismo frente à perspectiva da autoemancipação da classe trabalhadora brasileira}

Diante dos elementos abordados, concebemos que os principais desafios enfrentados pelo novo sindicalismo se colocaram de forma contraditoriamente associada às suas características.

Nesse sentido, entendemos que o novo sindicalismo adquiriu significativa potencialidade enquanto movimento de massas. Porém, identificamos como um dos seus desafios o fato de que este se iniciou e se manteve frágil em relação à questão da organização e da direção política coletiva, no sentido da construção da luta estratégica pelo socialismo a partir das demandas da classe trabalhadora e das lutas populares, 
que se expressou desde o movimento grevista de 1978 a 1980 e que se manteve durante essa década. Nesses termos, o novo sindicalismo se desenvolveu sem romper com a predominância da espontaneidade na atuação sindical, privilegiando em determinados momentos ações basistas, e deixando em diversas conjunturas os rumos do movimento sindical sob o poder de decisão do ânimo das massas, estabelecido nas grandes greves e assembleias.

Apesar de a fundação de organizações como o PT e a CUT ter significado um passo importante em relação à questão da organização, a construção de uma direção política de caráter coletivo enquanto principal referência para a classe trabalhadora e para os segmentos populares foi ficando cada vez mais restrita à liderança exercida por Lula da Silva. Tal situação, contraditoriamente, acabou privilegiando a sua liderança individual em detrimento do fortalecimento das organizações enquanto espaços coletivos de direção, fundadas como parte da trajetória do novo sindicalismo.

A partir dessa constatação, não estamos secundarizando a força e referência adquiridas tanto pelo PT quanto pela CUT no interior da classe trabalhadora e da esquerda, que inclusive continuaram se expandindo após o período de existência do novo sindicalismo. Todavia, chamamos a atenção para o fato de que não se conseguiu consolidar uma direção política de caráter coletivo durante o processo do novo sindicalismo - que foi o contexto de maior ascenso da luta sindical e das lutas da classe trabalhadora no país - e isso teria sido fundamental para que uma perspectiva de projeto societário vinculado aos interesses da classe trabalhadora avançasse.

Um segundo desafio do novo sindicalismo que, segundo identificamos, surgiu e se manteve durante sua existência, foi o que se deu a partir da constituição de sua força social própria, pois, ao avançar por meio do movimento grevista e das mobilizações, passou a vivenciar o desafio da condução da luta sindical por parte dos(as) próprios(as) trabalhadores(as) que foram se deparando com a complexidade e as diferenças - econômicas, culturais, políticas, sociais, ideológicas, raciais e de gênero - existentes intraclasse. 
Essa realidade se deu de forma associada aos limites impostos pela pouca experiência tanto das bases quanto das lideranças em relação à luta sindical e à luta política, uma vez que, desde o início da ditadura civil-militar, a classe trabalhadora estava mais familiarizada com as ações de resistência e sobrevivência frente à repressão estatal do que com os desafios impostos por uma realidade caracterizada pelo ascenso de suas lutas.

Tal situação, associada a um histórico de fragilidade da organização política da classe trabalhadora - determinada pela sua complexa formação, pela preponderante condição de superexploração e pela predominância da repressão e da cooptação por parte do Estado e das classes dominantes frente às suas lutas -, impossibilitou que o novo sindicalismo avançasse no sentido de partir do patamar de acúmulo de força social própria conjuntural para o de construção de um projeto de classe que fortalecesse a luta sindical sob uma perspectiva estratégica.

O acúmulo de forças adquirido pelo novo sindicalismo frente à dinâmica das lutas de classes, estabelecida em um período em que as classes dominantes, enquanto principais beneficiadas pela ditadura civil-militar, conseguiram manter sua hegemonia durante a transição democrática, não propiciou que se alcançasse um patamar decisivo de luta entre as classes. Diante disso, o novo sindicalismo não reuniu força social suficiente para possibilitar uma conjuntura que pudesse avançar para uma disputa decisiva entre as classes, o que seria necessário para que as lutas da classe trabalhadora avançassem na perspectiva da autoemancipação.

Associado a isso, outro desafio enfrentado pelo novo sindicalismo, como um dos principais desdobramentos da expansão e da influência que este passou a exercer no todo do movimento sindical, foi a fundação de organizações sindicais e partidárias, a exemplo do PT e da CUT.

Nessa perspectiva, apontamos primeiramente que esse fato significou um avanço no sentido de ter sido um passo importante em relação ao processo de organização da classe trabalhadora. Porém, ao considerarmos o histórico das lutas da classe trabalhadora no país, observamos que a formação dessas organizações também consolidou uma divisão tanto no movimento sindical quanto na esquerda de uma forma geral, 
em que passaram a se conformar um campo político vindo do novo sindicalismo e vinculado ao PT e à CUT e outro campo político que, por meio da Unidade Sindical, fundou a CGT e permaneceu vinculado ao Partido Comunista Brasileiro (PCB).

Dessa maneira, mesmo naquele contexto de ascenso do movimento sindical, em que a classe trabalhadora conseguiu acumular forças graças às suas lutas e tensionar o processo de transição democrática, defendendo seus direitos e interesses historicamente negligenciados pelo Estado brasileiro, o PT e a CUT, enquanto organizações criadas durante o novo sindicalismo, apesar de terem conseguido, desde o seu início, exercer significativa inserção nas bases da classe trabalhadora, não lograram promover, do ponto de vista tático e estratégico, avanços em relação à construção da unidade da classe e da esquerda.

Contudo, é importante colocar que, ao se ter como referência o histórico das lutas da classe trabalhadora no país, a permanência das dificuldades acerca da concretização da unidade política entre as organizações de esquerda, durante a década de 1980, também expressava os desafios que vinham se intensificando desde o período anterior à instalação da ditadura civil-militar, em 1964.

As divergências que foram ocorrendo de forma mais explícita, tanto no movimento sindical quanto na esquerda, desde o período de fundação da CUT, demonstravam que, assim como havia acontecido em outros momentos importantes das lutas de classes no país, as organizações de esquerda não conseguiram atuar sob a perspectiva de construção de um programa unitário que, considerando as particularidades da formação social brasileira e as especificidades intraclasse, defendesse e representasse os seus interesses como um todo. Essa questão permaneceu, durante e após o novo sindicalismo, como um aspecto limitador para o avanço das lutas da classe trabalhadora em relação ao desafio histórico da sua autoemancipação.

Além desses, outro desafio que constatamos diante do processo do novo sindicalismo foi o que surgiu em decorrência da expansão das greves e mobilizações durante a década de 1980, as quais, ao adquirirem um caráter de enfrentamento e uma dimensão generalizante, elevaram as 
lutas de classes a novos patamares e propiciaram que a classe trabalhadora atuasse enquanto classe frente aos determinantes e contradições da época.

Entretanto, ao atingir esses novos patamares, o novo sindicalismo demonstrou limites em articular a luta sindical e a luta política sob a perspectiva revolucionária. Dessa forma, apontamos primeiramente a complexidade que existe, de maneira intrínseca, na articulação das duas dimensões dessas lutas, uma vez que, para a dimensão política avançar, é necessário, juntamente com as reivindicações e experiências organizativas da classe trabalhadora, que se construa mediante a experiência concreta da luta uma concepção ideológica de mundo que inclua o reconhecimento e a defesa de um projeto de sociedade - desafio que se estabelece de forma contraditória e processual, diante das condições objetivas historicamente estabelecidas pela dinâmica das lutas de classes e das condições subjetivas que dizem respeito à caracterização e ao modo de ser da própria classe trabalhadora.

Além disso, identificamos que o histórico de enfraquecimento da luta revolucionária no contexto internacional - envolvendo o movimento comunista entre as décadas de 1960 e 1980, que se desagregou diante da falência das experiências do chamado "socialismo real" - e as dificuldades políticas e organizativas enfrentadas pelo PCB - enquanto principal referência do movimento comunista no Brasil - desde o período pré-64 no Brasil, foram aspectos que contribuíram para que as lutas sob o horizonte revolucionário fossem ficando cada vez mais frágeis.

Considerando esses elementos, percebemos que, durante a trajetória do novo sindicalismo, principalmente desde meados da década de 1980, por meio da atuação da CUT, deu-se um processo em que, por mais que as greves tenham se expandido, a perspectiva da luta pelo fim da exploração enquanto horizonte político foi se distanciando da luta sindical. Junto a isso, foi se ampliando internamente na Central a perspectiva social-democrata, caracterizada em linhas gerais pelo reformismo, pela tática da negociação e pela colaboração de classes.

Em virtude das contradições impostas pela realidade brasileira e da forma como foi se dando a transição democrática, o que se viu foi uma tendência de a atuação da CUT, enquanto central sindical herdeira 
do novo sindicalismo, limitar-se cada vez mais à dimensão da luta econômica e corporativa.

\section{Considerações finais}

Tendo como referência os fundamentos e a atualidade da teoria da revolução em Marx, ressaltamos a centralidade que as lutas de classes assumem no contexto geral da sociedade burguesa, entendendo que estas incidem na formação das próprias classes sociais, que se caracterizam pelo lugar e papel que ocupam no sistema produtivo e pelos aspectos particulares que as constituem no contexto das formações sociais e de conjunturas específicas.

Assim, concebemos que as formas de luta de uma determinada classe expressam suas características objetivas e subjetivas, ao tempo em que constituem a própria classe. Por isso, ao reconhecermos na formação da sociedade burguesa a essencial relação de antagonismo e interdependência entre burguesia e classe trabalhadora - considerando também a heterogeneidade que existe internamente em cada uma dessas classes - apontamos que as lutas têm um papel central para a formação da classe trabalhadora enquanto classe no seu sentido político, ou seja, enquanto classe potencialmente revolucionária da sociedade burguesa.

Associado a isso, considerando o contexto histórico e as particularidades da formação social brasileira durante o período de consolidação da ordem monopólica no país durante a ditadura civil-militar, reconhecemos que as lutas de classes se acirraram a partir da segunda metade da década de 1970 devido ao aprofundamento do caráter dependente da economia, à intensificação da condição de superexploração vivenciada pela classe trabalhadora e ao fortalecimento do caráter autocrático da dominação burguesa no país. Esse processo se deu de forma interligada à consolidação do poder imperialista no país, ao aumento da concentração da renda e da riqueza e em consequência da desigualdade social, firmando a tendência do capitalismo brasileiro de excluir a grande maioria da população ao acesso aos direitos de cidadania, às políticas sociais e aos benefícios proporcionados pelo desenvolvimento econômico. 
Assim, essa realidade, associada à expansão da classe trabalhadora ocorrida principalmente entre os anos 1968 e 1975, proporcionou, diante das condições históricas daquele período, o início da fase de maior avanço das lutas da classe trabalhadora no país, a exemplo do que foi a constituição do novo sindicalismo a partir das greves de 1978 e 1980.

Nessa perspectiva, o novo sindicalismo se constituiu a partir do amplo movimento grevista estabelecido na época e desenvolveu diversas experiências de luta e organização envolvendo diferentes segmentos da classe trabalhadora - com o protagonismo do operariado do ABC paulista -, enfrentando a política econômica consolidada pelo regime ditatorial, contestando a estrutura sindical existente e a atuação repressora do Estado.

Dessa forma, identificamos que ao associar, naquele contexto de acirramento, as lutas de classes às lutas dos movimentos sociais de caráter popular e do sindicalismo rural; ao articular as lutas corporativas com a luta pela retomada do regime democrático; e ao desenvolver experiências organizativas de forma associada às mobilizações, coordenando desde os comitês de fábricas durante as greves até uma central sindical em nível nacional - a exemplo do que foi a fundação da CUT em 1983 -, o novo sindicalismo adquiriu uma significativa importância política para as lutas da classe trabalhadora brasileira.

Por isso, ao reconhecermos esse significado político, apontamos, com base nos estudos de Antunes (1988), Boito Júnior (1991), Frederico (1979; 1991; 1994; 2014) e Santana (1999; 2003; 2017) suas principais características. A partir disso, foi possível identificar parte dos principais desafios que particularizaram o novo sindicalismo enquanto uma experiência de luta que, no contexto da formação social brasileira e frente ao histórico das lutas da classe trabalhadora no país, foi síntese de alguns dos seus principais enfrentamentos no contexto do desafio histórico da sua autoemancipação.

Assim, elencamos: a fragilidade em relação à questão da organização e da direção política coletiva; o acúmulo de força social própria apenas na dimensão conjuntural; dificuldades para o alcance da unidade da classe trabalhadora e da esquerda; e significativos limites na articulação entre a 
luta sindical e a luta política sob a perspectiva revolucionária, sendo que no decorrer da década de 1980 essa problemática foi se aprofundando.

Diante disso, apesar de o novo sindicalismo ter sido uma expressão central do período de maior avanço das lutas da classe trabalhadora no Brasil, ele não conseguiu, nos marcos da formação social brasileira, incidir para que houvesse avanços para a concomitância entre uma situação revolucionária enquanto resultante do acirramento das lutas de classes e a efetivação da condição potencialmente revolucionária da classe trabalhadora.

Não obstante, esse foi um processo em que a classe trabalhadora brasileira experimentou, em alguma medida, por meio da luta, a defesa de seus direitos e interesses, o que contribuiu centralmente, naquele contexto, para a sua trajetória de constituição enquanto classe potencialmente transformadora da sociedade burguesa, ao tempo em que lançou para essa classe trabalhadora, sob essa perspectiva, inúmeros e complexos desafios, dentre os quais se encontram os que identificamos.

\section{Referências}

ANTUNES, Ricardo. A rebeldia do trabalho (o confronto operário no ABC paulista: as greves de 1978/80). São Paulo: Ensaio, Campinas: Unicamp, 1988.

ANTUNES, Ricardo. Adeus ao trabalho? Ensaio sobre as metamorfoses e a centralidade do mundo do trabalho. 14. ed. São Paulo: Cortez, 2010. ANTUNES, Ricardo. O continente do labor. São Paulo: Boitempo, 2011. BADARÓ, Marcelo. Trabalhadores e sindicatos no Brasil. 1. ed. São Paulo: Expressão Popular, 2009.

BOITO JÚNIOR, Armando. Reforma e persistência da estrutura sindical. In: BOITO JÚNIOR, Armando et al. (org.). O sindicalismo brasileiro nos anos 80. Rio de Janeiro: Paz e Terra, 1991.

FREDERICO, Celso (org.). A esquerda e o movimento operário 19641984: a reconstrução. Belo Horizonte: Oficina de livros, 1991. v. 3. 
FREDERICO, Celso. A vanguarda operária. São Paulo: Símbolo, 1979. FREDERICO, Celso. Crise do socialismo e movimento operário. São Paulo: Cortez, 1994.

FREDERICO, Celso. O presente como história. In: IASI, Mauro Luís; COUTINHO, Eduardo Granja. Ecos do golpe: a persistência da ditadura 50 anos depois. 1. ed. Rio de Janeiro: Mórula, 2014.

MARINI, Ruy Mauro. Dialética da dependência. In: STEDILE, João Pedro; TRASPADINI, Roberta (org.). Ruy Mauro Marini: Vida e Obra. 1. ed. São Paulo: Expressão Popular, 2005.

MARX, Karl. A questão judaica. [1843]. In: MARX, Karl. Manuscritos Económico-Filosóficos. Lisboa: Edições 70, 1993.

NETTO, José Paulo. O que é marxismo. 9. ed. São Paulo: Brasiliense, 1994. (Coleção Primeiros Passos).

SANTANA, Marco Aurélio. A queda do equilibrista: o PCB e os sindicatos no Brasil (1945-92). In: MAZZEO, Antônio Carlos; LAGOA, Maria Izabel (org.). Corações vermelhos: os comunistas brasileiros no século XX. São Paulo: Cortez, 2003.

SANTANA, Marco Aurélio. Política e história em disputa: o novo sindicalismo e a ideia de ruptura com o passado. In: RODRIGUES, Iram Jácome (org.). O Novo Sindicalismo vinte anos depois. Petrópolis: Vozes, São Paulo: Educ-PUC-SP, São Paulo: Unitrabalho, 1999, v. 1, p. 133-162. SANTANA, Marco Aurélio. Trabalhadores em movimento: o sindicalismo brasileiro nos anos 1980/1990. In: FERREIRA, Jorge; DELGADO, Lucília Almeida Neves (org.). O Brasil Republicano: O tempo da ditadura: regime militar e movimentos sociais em fins do século XX. 8. ed. Rio de Janeiro: Civilização Brasileira, 2017, v. 4, p. 283-313. 


\title{
Capitulo 3 \\ temporário no \\ Estado capitalista
}

\author{
Eduardo Augusto Rodrigues Barros \\ Universidade de Brasília (UnB) \\ eduardo.barros@sejus.df.gov.br
}

\section{Introdução}

O trabalho temporário é uma modalidade de trabalho atípica, ou seja, difere do modelo tradicional de trabalho, em que a relação se dá diretamente entre trabalhador e capitalista em uma relação direta de subordinação, por prazo indeterminado. Este texto aborda as expressões do trabalho temporário no âmbito do Estado capitalista, e também retrata essa modalidade de trabalho no serviço público com ênfase nas unidades de medidas socioeducativas do Distrito Federal. 
Desse modo, a presente investigação foi embasada em pesquisas documentais e bibliográficas relacionadas ao tema. Além disso, realizou-se pesquisa de campo, de cunho qualitativo, por meio de entrevistas semiestruturadas ${ }^{1}$ com dirigentes sindicais da política socioeducativa no Distrito Federal, respeitando-se os critérios éticos determinados para a pesquisa com seres humanos.

Cabe esclarecer que a modalidade contrato temporário não é a única forma atípica de trabalho, pois existem, no atual momento do desenvolvimento capitalista na história, outras formas de trabalho precarizadas no meio urbano, como é o caso das modalidades de trabalho terceirizado, intermitente, eventual e parcial, por exemplo.

Tais espécies de contratos de trabalho, juntamente com o temporário, são entendidas como formas de precarização das condições de vida da classe trabalhadora, tendo em vista que esse tipo de contratação da força de trabalho dificulta o planejamento, a estabilidade econômica e as estratégias de sobrevivência e organização dos trabalhadores, deixando-os sob a constante disponibilidade das demandas capitalistas no atual estágio de mundialização² financeira do capitalismo hegemônico. Assim, este texto objetiva analisar o trabalho temporário no serviço público, tendo como recorte a realidade das Unidades de Medidas Socioeducativas do Distrito Federal.

1 A perspectiva crítica, em matéria de concepção de investigação, situa-se em reação contra o empiricismo e o positivismo da sociologia convencional, sem descartar, no entanto, a exigência antiteoricista de questionar a realidade concreta. Para se conseguir tal objetivo, é necessário um exame dos mecanismos sociais e cognitivos operantes nos instrumentos de investigação (questionários e entrevistas), tendo em vista a localização e o controle das interferências ideológicas que se manifestam nas obtenções dos dados. Tal exame, associado a uma crítica da concepção fisicista da observação, conduz à definição de um modo de questionamento suscetível de estabelecer uma intercomunicação entre o polo investigador e o polo investigado (THIOLLENT, 1987, p. 30).

2 A mundialização do capital pode ser expressa basicamente como um conjunto de fatores ligados ao uso das novas tecnologias a serviço do capital, à liberalização e à desregulamentação dos Estados nacionais quanto à economia dos seus mercados internos (CHESNAIS, 1996). 


\section{O trabalho temporário no capitalismo}

A partir das concepções de superacumulação e de capitalismo hegemônico, a modalidade de trabalho temporário pode ser considerada como uma expressão do desenvolvimento capitalista na história e, no que diz respeito à sua inserção no serviço público, existe uma essencial imbricação relacional com um modelo específico de Estado - o capitalista - que atua ativamente na luta de classes para atender às exigências das forças produtivas e de circulação dominantes (OSÓRIO, 2014; POULANTZAS, 2000) sob a atual égide da financeirização, não sem contradições, permeada pela luta de classes.

Nesse panorama, o trabalho temporário tornou-se uma tendência a partir da crise do modelo fordista ${ }^{3}$, que se deu no contexto de reestruturação produtiva ${ }^{4}$ do capital nos países centrais no século XX, na década de 1970. A crise do modelo de produção e organização do trabalho fordista e da era do pleno emprego gerou o não atendimento das necessidades de superacumulação capitalista, pois esta precisava reestabelecer suas bases de valor.

O capital, visando romper com a estagnação econômica e voltar ao pleno crescimento e expansão capitalista, remodela a forma de organização da produção, o que incide diretamente em novos procedimentos para a concretização do trabalho humano. Os Estados nacionais, sejam eles centrais, sejam periféricos, comprometidos com a plena expansão do capital, logo se aparelham para o maior desenvolvimento possível das forças produtivas.

3 Partindo do pressuposto taylorista, Henry Ford introduz a linha de produção em série, na qual o grau de complexidade da produção foi simplificado ao máximo. Assim, o objeto que se tornaria o produto final era colocado em um mecanismo automático que percorresse todas as fases produtivas, em que operários ficavam posicionados rigidamente no decorrer dessa linha de produção, desde o estágio inicial até o acabamento final do produto (PINTO, 2013).

${ }_{4}$ De base tecnológico-organizacional, incluindo a nova divisão da organização do trabalho e o modelo de organização da grande empresa, de base salarial-contratual (“flexibilização" da legislação trabalhista) e de base sociometabólica (espírito do toyotismo e valores-fetiches do capital) (ALVES, 2018, p. 35). 
Nessa lógica, retomam a política neoliberal como uma alternativa para melhor atender aos interesses da nova era, que surge por meio da então reestruturação produtiva, a chamada acumulação flexível ${ }^{5}$ (HARVEY, 2013). Esse novo período, em pujante andamento até os dias de hoje, irá exigir uma nova cultura humana, pautada na volatilidade, flexibilidade e polivalência (ALVES, 2000; ANTUNES, 2015; DAL ROSSO, 2008a), em que o trabalho temporário e os demais trabalhos atípicos ganham notoriedade (VASAPOLLO, 2005) e passam a ser o carro-chefe das contratações da força de trabalho, o que afeta diretamente a regulamentação e a proteção do trabalho humano.

\subsection{Surgimento do trabalho temporário}

O trabalho temporário urbano na prestação de serviços privados não é uma forma de contratação recente, pois teve início de forma ainda não regulamentada na década de 1940, de acordo com Cordeiro e Mota (2010). Seu surgimento se deu nos Estados Unidos, mais precisamente na cidade de Milwaukee, no estado de Wisconsin (CORDEIRO; MOTA, 2010).

Nesse período, surgiram nos EUA grandes empresas de arregimentação de força de trabalho temporário, como a Sam Workman, a Stivers Office Services, a Kelly Office Services, a Labor Pool, a Manpower e a Olsten (CORDEIRO; MOTA, 2010). Entretanto, sua regulamentação se deu na França, na década de 1970, na modalidade de empresa interposta, ou seja, um modelo triangular atípico em que há relação direta entre trabalhador e patronato. Isso significa que uma empresa tomadora demandará trabalhadores temporários a outra empresa prestadora de serviços de arregimentação de força de trabalho temporário, ficando o trabalhador temporário transversal a essa mediação (CORDEIRO; MOTA, 2010).

5 A acumulação flexível é definida por Harvey (2013) como uma nova forma de produção pautada na polivalência, na intensidade do trabalho e na desregulação das leis que protegem o(a) trabalhador(a), tornando as jornadas de trabalho flexíveis. 
O empresariado brasileiro, no mesmo movimento dos países capitalistas centrais, passou a pressionar o poder legislativo do Estado capitalista para que se aprovasse o projeto de lei que regulamentava o trabalho temporário urbano em serviços privados no Brasil, ganhando mais força após a aprovação da lei francesa a respeito dessa questão. Essa pressão veio, principalmente, de setores da sociedade civil organizada, como a Associação de Empresas de Trabalho Temporário (Asserttem) e a Associação Comercial do Rio de Janeiro (ACRJ), que tiveram um relevante papel na aprovação da lei de regulamentação do trabalho temporário no Brasil (WIEGERINCK, 1999).

Nesse sentido, Wiegerinck (1999) entende que a Legislação Trabalhista brasileira (1943) necessitava de modificação para acompanhar o desenvolvimento de uma moderna sociedade plural. Porém, evidencia-se nesse autor uma forte visão empresarial, em detrimento das necessidades dos trabalhadores; da mesma forma, Prunes (1995), outro estudioso defensor dessa modalidade contratual de força de trabalho, afirma que o trabalho temporário é elementar para atender aos interesses da lucratividade, podendo ser contínuo ou cíclico.

Entretanto, ao se partir do ponto de vista da centralidade do trabalho, a estipulação de um prazo para o fim do contrato entre trabalhadores e capitalistas poderia gerar o fenômeno do desemprego e riscos para a sobrevivência do trabalhador e da trabalhadora, como também de suas famílias.

\section{O trabalho temporário nos serviços privados e públicos no Brasil}

A regulamentação do trabalho temporário urbano no Brasil na prestação de serviços privados se deu em 1974, por meio da Lei Federal $n^{\circ}$ 6.019, de 3 de janeiro de 1974 (BRASIL, 1974). A regularização do trabalho temporário estabeleceu uma contradição, pois, ao tempo em que oferecia possibilidades, por meio da garantia de alguns direitos e obrigações por parte dos empresários, em contrapartida flexibilizava as relações de trabalho, o que fortaleceu uma tendência que viria a ganhar contornos mais profundos no século XXI, como foi visto com 
a própria alteração dessa normativa no Brasil, por meio da Lei Federal no 13.429/2017, no bojo da Contrarreforma Trabalhista em $2017 .{ }^{6}$

Nesse sentido, a Lei $n^{0}$ 13.429/2017 (BRASIL, 2017) altera a Lei $n^{\circ}$ 6.019/1974 (Lei do Trabalho Temporário). Nessa alteração, é estabelecido que a contratação de trabalhadores temporários deverá ser realizada apenas pela relação triangular de empresas interpostas. Apesar de essa relação ser recorrente, a Lei $n^{\circ} 6.019$ ainda permitia que empresas contratassem diretamente trabalhadores temporários. Essa relação triangular permite maior flexibilidade à empresa tomadora de serviço para dispor de força de trabalho sem maiores barreiras de proteção trabalhista.

Essa lei dispõe sobre as relações de trabalho na empresa de prestação de serviços a terceiros e ainda aumenta o prazo para o término do contrato de trabalho, o que permite a ampliação do tempo durante o qual o trabalhador permanece em uma condição instável. Antes, o prazo máximo para o fim do contrato de trabalho temporário era de seis meses, mas agora essa modalidade de trabalho pode durar até nove meses ininterruptos.

Nesse contexto, a citada lei institui juridicamente a terceirização generalizada tanto na área meio quanto na área fim, mediante uma empresa prestadora de serviços, colocando no mesmo bojo duas naturezas distintas de contratação. A diferença é que, no trabalho temporário, há fornecimento de trabalhadores com prazo determinado para o fim da contratação, por meio de empresa interposta, ou seja, empresa de trabalho temporário. Já a contratação de força de trabalho terceirizado diz respeito à prestação de serviços por uma empresa especializada e com prazo indeterminado.

Os trabalhadores temporários não possuem nenhuma relação empregatícia com a empresa tomadora de serviço. Apesar de terem ligação contratual com a prestadora, possuem relação de subordinação e pessoalidade diretamente com a empresa tomadora de serviço.

Desse modo, a Lei $\mathrm{n}^{0}$ 13.429/2017 foi uma forma mais aprofundada de atender aos interesses da mundialização financeira dos países

6 Os direitos sociais e trabalhistas foram garantidos em legislações, como é o caso da Consolidação das leis do Trabalho no Brasil, em 1943 (CLT/1943). As contrarreformas são um conjunto de ações que destroem esses direitos conquistados (BEHRING, 2008). 
centrais e da burguesia nacional, tornando-se possível graças ao estabelecimento de contrarreformas viabilizadas em um contexto de golpe no Brasil que destituiu Dilma Rousseff do poder, em 2016, integrando o Brasil aos interesses do capitalismo central em sua forma mais acirrada.

Esse movimento permitiu maior centralização e acumulação de capitais por meio da desregulamentação do trabalho e congelamento em investimentos estatais nas áreas de saúde, assistência social, educação, medidas socioeducativas, ciência, tecnologia e cultura, por meio da aprovação da Emenda Constitucional n ${ }^{\circ}$ 95, que estabelece o teto de gastos públicos nos setores de interesses coletivos supracitados, atendendo às demandas do capital rentista parasitário.

Antunes (2018, p. 168) afirma que a lei de terceirização "instaura uma nova servidão do trabalho” nos moldes do século XXI, ou seja, salários mais rebaixados, possibilidade de quarteirização de contratação do trabalho, menos direitos trabalhistas e maior flexibilidade para contratação e descontratação, dificultando, ainda, a mobilização coletiva de contraofensiva da classe trabalhadora, com uma efetiva organização sindical.

Esse cenário de contrarreformas à "classe que vive do trabalho" (ANTUNES, 2015) no Brasil deve ser analisado sob a ótica da formação social e política do Estado autocrático capitalista brasileiro, que, historicamente, sempre buscou conservar privilégios e adquirir mais vantagens para a elite nacional, sem comprometer os interesses dos Estados capitalistas centrais na região (FERNANDES, 1976).

A aplicação do trabalho temporário urbano nos serviços públicos, assim como aquele utilizado nos serviços privados, também guarda uma profunda relação com o desenvolvimento das forças produtivas capitalistas. Entretanto, essa relação se dá por meio de uma interação direta com o Estado capitalista, lócus de efetivação dos serviços públicos.

A contratação de trabalhadores temporários estatais no Brasil é prevista no art. 37, inciso IX, da Constituição Federal de 1988 (CF/88), e deve apresentar três requisitos, segundo Borges e Duarte Jr. (2009): necessidade de excepcional interesse público, temporariedade da função e contratos firmados com prazo determinado. Para fins administrativos, esses trabalhadores são tidos como servidores públicos e enquadram o 
rol de agentes públicos (DI PIETRO, 2015), embora a natureza do seu vínculo seja especial.

\subsection{A contratação temporária por motivos não excepcionais no serviço público}

A contratação de servidores públicos temporários deve obedecer às pré-condições previstas constitucionalmente e, diferentemente do trabalhador temporário contratado para fins privados, aquele destinado a executar funções públicas deve ser contratado diretamente pelo contratante, ou seja, pelo Estado capitalista, por meio de processo simplificado.

Essa seleção, que foge ao critério mais democrático que é a via do concurso público, mesmo que para suprir temporariamente cargos para funções públicas, pode conter vícios relacionados ao patrimonialismo, fisiologismo, corporativismo e assédio moral. ${ }^{7}$ Essas relações incidem diretamente nas relações de trabalho no serviço público brasileiro, pois, apesar de históricas no desenvolvimento do Estado capitalista brasileiro e, por consequência, nos seus serviços públicos, retomam um conservadorismo regional, derruindo uma frágil concretização de um Estado democrático de direito no Brasil (PAULO, 2018; CARDOSO JR., 2011; NUNES, 2003).

É importante enfatizar que, quando utilizada em casos excepcionais para suprir demandas emergenciais, a contratação de servidores públicos temporários não representa uma burla aos concursos públicos ou ataque ao Estado democrático de direito. A problemática se instala

7 1. Patrimonialismo: quando os interesses nas relações estatais, o privado e o público se misturam (NUNES, 2003). 2. Fisiologismo: quando agentes públicos usam a máquina estatal para interesses privados ou partidários, visando a apropriação do poder (NUNES, 2003). 3. Corporativismo: quando os interesses de um determinado grupo prevalecem sobre os interesses de uma grande maioria (NUNES, 2003). 4. Assédio moral: quando, nas relações de trabalho, devido a uma posição hierárquica diferente ou de mesmo nível, as pessoas são expostas a situações constrangedoras e humilhantes de forma prolongada (PAULO, 2019). 
quando o Estado capitalista, sob a égide neoliberal, ${ }^{8}$ passa a utilizar esse recurso de forma recorrente para suprir vagas efetivas no serviço público, em atividades não consideradas prioritárias pela política econômica vigente, em concordância com a financeirização, como a execução de políticas sociais que englobam saúde, educação e medidas socioeducativas, a exemplo do que ocorreu e vem ocorrendo nos serviços públicos do Distrito Federal nas áreas supracitadas, principalmente.

A Lei Federal no 8.745/1993 regulamenta a contratação dos servidores públicos temporários e estipula que o caráter de excepcional necessidade que justifica essa modalidade contratual são

\begin{abstract}
situações de calamidade pública, o combate a surtos endêmicos, a realização de recenseamentos, a admissão de professor substituto e professor visitante, a admissão de professor e pesquisador visitante estrangeiro, e as atividades especiais nas organizações das Forças Armadas para atender a área industrial ou a encargos temporários de obras e serviços de engenharia. (MAFRA FILHO, 2005, p. 1).
\end{abstract}

Mesmo com esses casos de excepcional necessidade, de acordo com Borges e Duarte Jr. (2009), o Supremo Tribunal Federal (STF) abriu um precedente para a contratação de temporários, em 2006, ao decidir favoravelmente ao executivo federal e burlar o concurso público, possibilitando contratações temporárias no Conselho Administrativo de Defesa Econômica (Cade), mesmo que essa contratação já perdurasse dez anos, julgando que os serviços públicos não poderiam ser paralisados em função da inércia da administração pública. Essa ação estabeleceu

8 “O Estado neoliberal, constituído nos países capitalistas centrais no decorrer da transição histórica para o capitalismo global na década de 1980 (e para países como o Brasil, por exemplo, na década de 1990) é a forma política do capital financeiro organizar sua dominação no âmbito territorial das unidades nacionais, organizando no seu interior, as alianças das frações de classe burguesa no bloco de poder sob a direção hegemônica da fração rentista parasitária do capital” (ALVES, 2018, p. 72). 
pressupostos para que houvesse servidores temporários em funções públicas permanentes e ordinárias (BORGES; DUARTE JR., 2009).

De acordo com Queiroz (2004), contratar servidores temporários para atender a necessidades estruturais e não excepcionais pode acarretar uma ineficiência da máquina pública, pois se investe na capacitação desses servidores a fim de que executem trabalhos muitas vezes complexos e delicados, para que depois tudo se perca com o término dos contratos. A existência de trabalhadores temporários em cargos públicos que deveriam ser efetivos pode afetar os destinatários dos serviços e da política pública em questão, pois implica uma descontinuidade e um novo recomeço dos serviços prestados, o que gera precarização e mais gastos públicos.

\section{O contrato temporário na carreira socioeducativa do DF e sua precarização}

No Distrito Federal, a norma que dispõe sobre os servidores públicos temporários no âmbito regional é a Lei Distrital nº 4.266/2008 (DISTRITO FEDERAL, 2008), nos termos do art. 37, IX, da Constituição Federal de 1988. Entretanto, essa normativa foi alterada em 2013, por meio da Lei Distrital no 5.240/2013 (DISTRITO FEDERAL, 2013), que amplia ainda mais as possibilidades de o Poder Executivo contratar, na área de saúde, servidores temporários em cargos permanentes. Assim, percebe-se que a prática de contratação de trabalho temporário em vagas públicas efetivas tem sido recorrente no Distrito Federal.

O Ministério Público entrou com ação de inconstitucionalidade acerca da emenda da lei orgânica do DF sobre a contratação temporária no âmbito da saúde. Em 2011, a Secretaria de Estado de Saúde demitiu 283 profissionais de diversas especialidades, como técnicos, dentistas, enfermeiros e médicos, que eram contratados temporariamente, mas estavam lotados no órgão desde 2006 (MAIA, 2011).

Em setembro de 2013, o portal R7 publicou notícia sobre irregularidades envolvendo servidores temporários, em que médicos contratados temporariamente estariam ganhando salários superiores ao de 
médicos efetivos, de modo que apenas um médico chegou a ganhar até R\$ 80.000,00 (oitenta mil reais) em procedimentos (MÉDICOS, 2013). Tal fato afeta diretamente a moralidade nos serviços estatais, ou seja, o público é tomado como privado para interesses pessoais relacionados à lucratividade.

Em 2015, o Governo do Distrito Federal (GDF) solicitou a prorrogação dos contratos temporários lotados tanto na Secretaria de Educação quanto na Secretaria de Saúde, de acordo com matéria publicada pelo Sindicato dos Servidores da Assistência Social e Cultural do GDF (Sindsasc), em 2016. O GDF alegou que essa solicitação foi feita porque a lei de responsabilidade fiscal impedia novas contratações de servidores públicos efetivos nas áreas de saúde e educação.

Ainda em relação à política de saúde, de acordo com matéria publicada em 11 de novembro de 2016 no portal G1, somente em 2016 o DF disponibilizou 337 vagas para médicos temporários, por meio de contratos com prazo de duração de 1 (um) ano (DF, 2016).

Assim, desobedecendo à recomendação do Ministério Público do Distrito Federal e Territórios (MPDFT) de suspender os contratos temporários, após a elaboração de uma portaria para contratação temporária, por meio de liminar judicial, foi permitido ao GDF o estabelecimento de contrato por 12 meses.

A Secretaria de Estado de Políticas para Crianças, Adolescentes e Juventude do Distrito Federal (Secriança-DF), que detinha responsabilidade sobre o planejamento e a execução das medidas socioeducativas, retomou a contratação de temporários, que já não eram utilizados desde o último concurso de 2010 (DISTRITO FEDERAL, 2014b).

Conforme informativo interno, a contratação temporária era uma prática necessária no governo; portanto ocorreria, a exemplo da Secretaria de Educação, com o intuito de manter funcionando todos os setores do órgão (DISTRITO FEDERAL, 2014a). No entanto, tal decisão indica um suprimento de força de trabalho mais barata para conseguir atender a uma demanda estrutural e não temporária, como prevê a legislação, que exige que a contratação do servidor temporário somente ocorra em caso de excepcional necessidade. 
No ano de 2016, foram cortados os benefícios de auxílio-alimentação e auxílio-transporte dos servidores temporários das medidas socioeducativas, tendo em vista parecer da Procuradoria-Geral do DF, que acreditava que o contrato temporário não dava ensejo a essas vantagens. Entretanto, segundo uma servidora temporária, o contrato inicial com a Secretaria que executava as medidas socioeducativas no DF garantia esses benefícios, além de férias e décimo-terceiro salário, de modo que o corte de tais benesses acarretaria quebra de contrato por parte do GDF (KARPOV, 2016).

Em resposta, o secretário de governo afirmou que esses benefícios não tinham uma previsão legal, com base na Lei Complementar Distrital $\mathrm{n}^{\circ}$ 840, de 23 de dezembro de 2011 (DISTRITO FEDERAL, 2011), e por isso estavam sendo cortados. Todavia, representantes da Secretaria ainda expuseram que, apesar de existir recomendação do MPDFT no sentido da nomeação de servidores efetivos para as referentes funções públicas permanentes nas medidas socioeducativas, a prática da contratação temporária é corriqueira há anos nas Secretarias do GDF, em prol de uma resolução paliativa para as situações críticas das políticas públicas (KARPOV, 2016).

Por meio da afirmação desses representantes governamentais, infere-se que a situação crítica é algo permanente e não eventual, ensejando, assim, uma distorção no princípio da aplicabilidade da contratação temporária conforme orienta a $\mathrm{CF} / 88$ e as respectivas regulamentações regionais acerca da inserção de servidores temporários no serviço público.

Em 2016, dos dois sindicatos (o Sindsasc e o Sindicato dos Servidores da Carreira Socioeducativa do DF - Sindsse/DF) existentes para defender os interesses dos servidores da carreira socioeducativa, ${ }^{9}$ apenas o Sindsasc se posicionou a favor dos temporários, alegando que, apesar de defender a convocação de servidores efetivos por meio de concurso público, não poderia compactuar com a retirada de direitos dos demais trabalhadores, mesmo que temporários, cobrando da Secretaria uma resolução da situação desses trabalhadores (SINDSASC, 2016).

9 Desde 2018, após decisão judicial e decisão do Ministério do Trabalho, somente o Sindsse/DF representa os servidores da carreira socioeducativa do Distrito Federal. 
Em 2018, o Sindsse anunciou, em seu sítio virtual, a determinação judicial que impedia a prorrogação dos contratos temporários e obrigava a convocação dos servidores efetivos que aguardavam a nomeação. Foi uma vitória para a carreira, conquistada, segundo a entidade, por meio da luta sindical, pois esse pedido havia sido realizado em ação processual de iniciativa do referido sindicato (SINDSSE/DF, 2018).

Por meio desse panorama, foi possível constatar que, apesar da pressão sindical e de recomendações do Ministério Público do DF, vagas do serviço público destinadas a servidores permanentes estavam sendo disponibilizadas a trabalhadores temporários, ferindo os princípios da moralidade, impessoalidade e eficiência da administração pública, uma vez que os critérios da seleção simplificada de temporários para cargos públicos estão sujeitos a subjetividades e interesses difusos dos gestores e/ou blocos de poder ${ }^{10}$ em disputa pela direção do Estado capitalista.

Tais vícios, presentes nos serviços públicos promovidos pelo governo, enfraquecem a noção do Estado democrático de direito. Entende-se que o abuso da alternativa da contratação de trabalhadores temporários pode se tornar uma ferramenta de governos neoliberais, com o objetivo de reduzir os gastos com as políticas sociais por meio da redução do custo com a força de trabalho - gerando, assim, mais precarização do trabalho e, por consequência, piora na prestação de serviços públicos considerados não essenciais para a gestão de governos neoliberais, como saúde, educação, medidas socioeducativas e outras áreas voltadas aos interesses coletivos.

A modalidade contratual de trabalho temporário é utilizada nas medidas socioeducativas do Distrito Federal desde 1990, tendo início na gestão do governador Joaquim Roriz (PTR/PMDB) e perdurando nos governos posteriores até 2010, quando foram efetivados um grande número de servidores. Entretanto, a alta crescente da violência urbana

${ }^{10}$ A classe dominante não é homogênea, de modo que no seu seio existem frações em torno do poder dominante. Essas frações são designadas como blocos de poder (OSÓRIO, 2014). 
envolvendo adolescentes ${ }^{11}$ demandou um número maior de pessoas para atuar na área, o que resultou no retorno dos trabalhadores temporários em 2014, no final da gestão do governo de Agnelo Queiroz (PT). Essa prática foi contínua no governo posterior, em 2015, na gestão de Rodrigo Rollemberg, do Partido Socialista Brasileiro (PSB), até que, por determinação judicial, a administração foi obrigada a não prorrogar os contratos temporários e a convocar os efetivos que aguardavam nomeação, devido à ação ajuizada pelo Sindsse/DF.

Atualmente, a carreira pública atua sem trabalhadores temporários; porém, o número de servidores efetivos não consegue suprir toda a necessidade do sistema socioeducativo. ${ }^{12}$ Essas condições estruturais a que está submetida a execução da política socioeducativa no DF, além de trazer prejuízos para a saúde e o bom exercício laboral dos trabalhadores nela inseridos, ainda provoca uma dissonância no tocante aos direitos humanos, de acordo com Carmo (2015), pois, para a autora, há um claro descumprimento da legislação que dispõe sobre o Sistema Nacional de Atendimento Socioeducativo (Sinase) - a Lei ${ }^{\circ} 12.594$, de 18 de janeiro de 2012 (BRASIL, 2012). ${ }^{13}$

A efetivação da Lei do Sinase perpassa a valorização dos servidores públicos enquanto executores dessa política; no entanto, as ofensivas do Estado capitalista no âmbito do GDF destacam uma tendência à

${ }^{11}$ Entre 2013 e 2014, houve um aumento de 84\% dos jovens internados no DF, saltando de 449 para 825 o número de adolescentes sentenciados com essa medida, de acordo com levantamento anual do Sinase (2013).

12 O GDF, mesmo com cinco unidades de internação, permanece enfrentando o problema de superlotação e violações de direitos, afora o mau funcionamento das medidas de meio aberto e semiliberdade, devido à falta de equipamentos, condições dignas de trabalho e força de trabalho suficiente para a execução desses serviços, de acordo com o Relatório Geral das Medidas Socioeducativas do DF, elaborado pelo Sindsse/ DF, juntamente com informações retiradas do Relatório do Conselho Nacional do Ministério Público, em 2014 (CNMP, 2013; LIMA, 2017).

${ }^{13}$ Art. $1^{\circ}[\ldots] \S 1^{\circ}$ Entende-se por Sinase o conjunto ordenado de princípios, regras e critérios que envolvem a execução de medidas socioeducativas, incluindo-se nele, por adesão, os sistemas estaduais, distrital e municipais, bem como todos os planos, políticas e programas específicos de atendimento a adolescente em conflito com a lei” (BRASIL, 2012). 
precarização das condições de trabalho. Assim, a inserção do trabalhador temporário pode ser vista com uma resposta residual e emergencial às necessidades da política pública socioeducativa, a qual, em virtude de decisões econômicas neoliberais, não poderia investir na contratação de novos servidores efetivos.

Em vista das pressões de entidades que defendem os direitos das crianças, dos adolescentes e dos trabalhadores da carreira socioeducativa, a resposta primária dos governos compromissados com a mundialização financeira tem sido a inserção do trabalhador temporário, para atender, ainda que de forma imediata e precária, às demandas das unidades de medidas socioeducativas.

A relação de atendimento socioeducativo está consolidada na Lei $n^{\circ}$ 12.594/2012 (BRASIL, 2012), que institui o Sinase, com base em um processo de continuidade das ações pautadas no vínculo entre adolescentes e servidores. Entretanto, a inserção de trabalhadores temporários pode ocasionar uma fragmentação desse vínculo, justamente pela relação de instabilidade e temporariedade que envolve essa modalidade contratual. Ademais, esse modelo de contratação pode prejudicar o seguimento do atendimento, o que deprecia ainda mais a relação entre servidores e adolescentes e, por consequência, a ressocialização de jovens em cumprimento de medida socioeducativa.

Os processos de trabalho ligados ao atendimento aos adolescentes que cumprem medida socioeducativa em estabelecimentos educacionais requerem relações, muitas vezes, de risco e alta complexidade, a fim de impedir fugas, no caso de internação; motins, rebeliões e ameaças de mortes; violências, torturas, uso e abuso de drogas, devido ao fato de esses jovens estarem inseridos em um contexto de criminalidade. ${ }^{14}$

${ }^{14}$ Segundo informação da Secretaria de Segurança Pública, a reincidência desses jovens na prática de atos infracionais chega a $85 \%$, e $25 \%$ destes cometem entre seis e dez infrações antes de serem internados. De acordo com os dados, uma em cada quatro armas ilegais que a polícia retirou de circulação estavam nas mãos de jovens de menoridade. Os crimes mais comuns praticados por eles são: roubo, tráfico de drogas, porte ilegal de arma de fogo e homicídio. A prática desses atos levou 85\% dos 
Essa realidade, associada a um número reduzido de servidores em condições de trabalho precarizadas, incide, muitas vezes, em risco para todos os trabalhadores da área, sendo os temporários ainda mais suscetíveis em razão do frágil vínculo, o que os torna vulneráveis até mesmo a uma relação de assédio moral e corporativista. Como exemplo, citam-se as atividades que contam apenas com dois servidores para fazer a segurança e o acompanhamento de mais de 25 jovens. São atividades educativas e de laze ${ }^{15}$ que os servidores efetivos se recusam a realizar, mas a que os trabalhadores temporários são obrigados pelas chefias imediatas.

Os estabelecimentos públicos responsáveis por executar medidas socioeducativas sofrem pressões de órgãos de controle, como o Ministério Público do Distrito Federal, e de organismos de defesa de direitos de crianças e adolescentes, além do próprio Judiciário ${ }^{16}$, para que se cumpram as normativas e diretrizes legais relacionadas aos direitos das crianças e dos adolescentes em situação de cumprimento de medida socioeducativa.

Dessa forma, os gestores do Estado capitalista, ou gerentes responsáveis pela condução da política e dos referidos estabelecimentos, pressionam seus trabalhadores para que executem funções dessas atividades relacionadas aos adolescentes sentenciados pelo judiciário com medida

adolescentes infratores aos centros de internação do Distrito Federal e corresponde a 80\% das infrações cometidas por esse segmento (MENORES, 2016).

${ }^{15}$ Informação obtida em entrevista com o diretor do Sindsse/DF.

${ }^{16}$ Em visita não agendada à unidade de internação, o Mecanismo Nacional de Prevenção e Combate à Tortura, da Secretaria Nacional de Direitos Humanos da Presidência da República, alertou para o fato de que as demandas sindicais estariam preponderando sobre as normas internas e a discricionariedade administrativa. Por determinação do sindicato, várias atividades de contato familiar dos adolescentes estariam sendo restritas, como uma forma de paralisação parcial da categoria. Segundo o promotor de Justiça Renato Varalda, “diante dos fatos, evidencia-se um enorme tumulto e prejuízo ao processo ressocializador.” Para o MPDFT, o réu valeu-se do cargo para, no exercício de sua função como presidente sindical, editar normas procedimentais inerentes ao Poder Executivo, ocasionando uma grave afronta aos direitos fundamentais dos internos e de suas famílias. Isso configura uma violação ao direito da legalidade administrativa e ao princípio da moralidade e legalidade, uma vez que seu exercício excedeu manifestamente os limites impostos pela lei, decorrentes de ato comissivo (MPDFT, 2016). 
socioeducativa, como o encaminhamento dos jovens à escola e às oficinas terapêuticas e profissionalizantes, o acompanhamento externo e o atendimento na rede de saúde e assistência social, além da garantia da atenção socioeducativa individual ao adolescente. Entretanto, exige-se a plena realização dessas atividades, mesmo sem a garantia da proteção dos trabalhadores que deverão efetivá-la.

Além das questões que envolvem a execução terminal de trabalho na política social por parte dos servidores, ainda podem existir os interesses políticos partidários em contratações, por meio de processo simplificado, com favorecimento de determinados blocos de poder em detrimento de outros, o que ocasiona processos fisiológicos e clientelistas por meio da execução de serviços públicos, enfraquecendo a concretização de uma democracia substantiva ${ }^{17}$ (OSÓRIO, 2014).

Cardoso Jr. (2011) ressalta que a fragilidade contratual governamental e os interesses partidários na correlação de força pela disputa do poder dominante no Estado causam a submissão dos trabalhadores temporários à constante vigilância por parte dos setores que os empregaram. Desse modo, qualquer situação divergente em relação aos interesses da manutenção desses blocos de poder poderia custar o desligamento dos servidores temporários e a contratação de outros.

Tal situação pode ser constatada em casos de greve e paralisação dos trabalhadores efetivos do sistema socioeducativo, em que os trabalhadores em regime temporário são obrigados a continuar suas atividades relacionadas à garantia de visita familiar, atendimento técnico especializado, atendimento jurídico, convivência coletiva, manutenção da rotina escolar e atividades de profissionalização e lazer, assim como desportivas, culturais e religiosas. ${ }^{18}$

\footnotetext{
${ }^{17}$ A democracia substantiva entende que proporcionar igualdades efetivas de condições, por meio de ações concretas do Estado, é fundamental para o ambiente democrático de fato, sendo o que se chama de liberdade positiva. Para Osório (2014), a democracia substantiva, diferente da democracia formal ou processual, faz frente aos interesses dominantes.

${ }^{18}$ Entrevista com o diretor do Sindsse/DF.
} 
A divisão entre trabalhadores efetivos e temporários no setor público das medidas socioeducativas no Distrito Federal, até quando se encerrou essa modalidade contratual no final de 2018, deve ser vista no contexto da heterogeneidade da classe trabalhadora sob a ótica da reestruturação produtiva, orientada pela nova gestão do trabalho e pautada na acumulação flexível (ALVES, 2000; ANTUNES, 2008; ANTUNES, 2015). Essa divisão, na nova tendência hegemônica do capitalismo mundial financeirizado, afeta a "classe que vive do trabalho" (ANTUNES, 2015), seja no setor público, seja no setor privado, embora haja distinções e particularidades.

A intenção é desmobilizar a classe trabalhadora em torno de um objetivo comum, dividindo os seus interesses e cooptando a sua subjetividade em torno de uma mentalidade voltada aos interesses do capital (ANTUNES, 2015). A divisão da classe entre trabalhadores com direitos assegurados e um grande contingente de trabalhadores expropriados de sua dignidade humana faz com que a organização coletiva dos trabalhadores seja afetada em sua unicidade, fragilizando os interesses de classe e, por outro lado, fortalecendo os interesses da classe dominante e do Estado capitalista. Esse movimento possibilita uma hegemonia neoliberal, ocasionando a geração de maior rentabilidade econômica a partir da espoliação da classe trabalhadora.

As vantagens econômicas que o Estado capitalista aufere a partir dos contratos temporários estão relacionadas a menores onerações do fundo público, em virtude da redução dos direitos trabalhistas. Por isso, é importante enfatizar que o trabalho temporário no serviço público foi mais utilizado no Distrito Federal em áreas que necessitavam de um grande contingente de força de trabalho, como as áreas de execução finalísticas das políticas sociais de serviços destinados à coletividade, como a saúde, além das políticas socioeducativas e educacionais.

Diferentemente das áreas relacionadas aos serviços sociais, aquelas referentes à gestão e fiscalização são consideradas estratégicas para o bom funcionamento do Estado capitalista e, por isso, são privilegiadas (BRESSER-PEREIRA, 1999), mesmo porque o corpo de trabalhadores desse setor é reduzido e possui alto grau técnico 
de qualificação em formação gerencial, por meio de escolas com ideologia voltadas à manutenção do status quo e ao pleno desenvolvimento do capital financeiro (KATZ, 2016).

Geralmente, esses trabalhadores, ou melhor, funcionários do capital, pertencem à classe reinante. ${ }^{19} \mathrm{~A}$ conservação desse corpo de trabalhadores deve ser garantida pelo Estado capitalista mediante relativa estabilidade no trabalho, incluindo direitos e benefícios. Destarte, o neoliberalismo que o governo do Distrito Federal pretende estabelecer a partir de 2019 busca retomar a política de terceirizações e o trabalho temporário nos serviços públicos, de modo que essas modalidades contratuais terão enfoque, principalmente, na prestação dos serviços sociais estatais, o que trará prejuízos à "classe que vive do trabalho" (ANTUNES, 2015) inserida nesses espaços.

A terceirização e o trabalho temporário podem afetar a democratização e a publicização dos serviços sociais executados diretamente para o atendimento das necessidades da classe trabalhadora, que geralmente demanda serviços coletivos gratuitos, como saúde e educação. Para garantir que essa relação seja estabelecida, é necessário um corpo de trabalhadores fortes e unificados para a realização de um projeto comum de carreira e sociedade, além de comprometidos com a população a quem se destina essa política, tendo em vista que, sob a égide neoliberal, as políticas sociais e os trabalhadores ficam à mercê de parcos recursos que proporcionam apenas a administração da pobreza (IAMAMOTO, 2008), função geralmente desempenhada em maior grau por trabalhadores temporários, parciais e terceirizados, mesclados com servidores efetivos.

${ }^{19}$ De acordo com Osório (2014), classe reinante é diferente de classe dominante. A classe reinante seria um corpo de trabalhadores com conhecimentos especializados que prestariam serviços públicos, formados nas principais escolas de reprodução do capital, as quais proporcionam uma visão de mundo e uma forma de resolver os problemas sociais sem questionar a ordem vigente. Os agentes públicos, nessa lógica, seriam responsáveis por administrar esse Estado e, por consequência, garantir os interesses da classe dominante. 
No que diz respeito à realidade regional do DF, foi possível analisar que houve, desde cerca 1990 até 2010, uma extrapolação da condição de excepcional necessidade prevista pela CF/88 no que se refere à contratação de trabalhadores temporários, a qual foi posteriormente retomada em 2014, perdurando até o final de 2018 nas instituições socioeducativas do DF. ${ }^{20}$

Nos últimos anos das contratações temporárias, foram tornadas públicas as diferenças em relação à questão da isonomia entre os servidores efetivos e os temporários ${ }^{21}$ que trabalhavam nas unidades socioeducativas, como o não pagamento da gratificação de risco aos temporários, que faziam jus a tal gratificação, pois estavam submetidos às mesmas situações de periculosidade.

Essa condição é constatada pela afirmação de Antunes (2018) de que os trabalhadores temporários e terceirizados ficam mais expostos a acidentes de trabalho e situações de risco, ao tempo em que há menos segurança institucional para protegê-los dos riscos iminentes. Percebe-se, também, que a diferença salarial entre temporários e efetivos

${ }^{20}$ Relatório Geral das Medidas Socioeducativas do DF, elaborado pelo Sindsse/DF (LIMA, 2017).

21 “Juíza titular do $1^{\circ}$ Juizado Especial da Fazenda Pública do DF condenou o Distrito Federal a pagar a servidor distrital a quantia correspondente ao adicional de insalubridade referente ao período indicado na planilha de cálculos elaborada pelo DF, acrescido das parcelas vencidas no curso do processo. O autor ajuizou ação de conhecimento contra o Distrito Federal, tendo por objeto a condenação do réu ao pagamento de adicional de insalubridade em grau máximo (20\%) durante o período em que laborou sob contrato temporário em unidade de internação integrante do Sistema Socioeducativo do DF. A julgadora explicou que o direito ao recebimento do Adicional de Insalubridade tem origem constitucional e está previsto na Lei Complementar nº 840/2011, que dispõe sobre o regime jurídico dos servidores públicos civis do Distrito Federal, bem como na Lei 8.112/90. O referido adicional tem por objetivo recompensar o servidor público pelo exercício em atividades que causam danos à saúde. A juíza citou que, de acordo com a lei, para a percepção do adicional de insalubridade, basta a caracterização da atividade como insalubre. Por outro lado, o direito cessa com a eliminação das condições ou dos riscos que deram causa a sua concessão. Assim, qualquer decisão da Administração Pública com relação à concessão ou não do direito deve pautar-se na verificação das condições do ambiente de trabalho e nas atividades desenvolvidas pelo servidor” (ASP, 2018). 
pode proporcionar sentimentos e atitudes de corporativismo entre os trabalhadores com vínculos contratuais diferenciados, pois trabalhadores efetivos podem não admitir que servidores que entraram no serviço público por processo simplificado tenham os mesmos direitos que eles, pertencentes à carreira pública de fato.

Os servidores efetivos passam por um processo de seleção altamente complexo, com ampla concorrência, por meio de concurso público. Essa diferença de inserção pode gerar um clima de animosidade, como foi relatado pelo diretor sindical do Sindsse, ${ }^{22}$ fato que prejudica a solidariedade de classe na carreira pública socioeducativa.

Os sujeitos históricos submetidos ao contrato de trabalho temporário vivenciam uma relação doentia no ambiente de trabalho, vez que são cobrados a exercer suas atividades com desempenho profissional de qualidade, com vistas a atender aos interesses dominantes, mas sem possuírem os mesmos direitos que os servidores efetivos e sob relações que se desenvolvem em um ciclo de subalternidade às forças políticas. ${ }^{23}$

As disputas pela direção do Estado capitalista estão plasmadas no serviço público, em que as competições por cargos entre os trabalhadores e a necessidade de ter trabalhadores subalternos e prontos para desempenhar quaisquer atividades faz com que esses trabalhadores executem ações para o fortalecimento da gestão do momento e, por consequência, da força política que a sustenta, muitas vezes em detrimento da prestação de serviços de qualidade à população a quem se destina determinada política pública. Os trabalhadores em contrato temporário devem experimentar mais ainda essa condição de subalternidade política, em virtude da sua relação de maior subordinação ao Estado capitalista, pela temporariedade do cargo público que ocupam.

Os discursos dos gestores públicos e dos agentes políticos se pautam em boa retórica socioeducativa, comprometida com o bem-estar coletivo, mas, concretamente, se orientam em prol dos interesses dominantes. O real compromisso com a gestão da política socioeducativa do

\footnotetext{
${ }^{22}$ Informação obtida por meio de entrevista com representante sindical do Sindsse/DF.

${ }^{23}$ Idem.
} 
DF, a partir de uma visão progressista e consistente com a realização de um programa emancipatório ${ }^{24}$ para adolescentes e servidores em uma relação dialética, passa pela valorização dos serviços públicos voltados às políticas sociais. ${ }^{25}$

Nessa direção, entende-se que uma gestão substantiva, de caráter efetivamente público e democrático, contraria os ideais neoliberais. Portanto, a garantia de uma política pública pautada na democracia substantiva é essencial para o desenvolvimento de ações voltadas a emancipar os jovens que cumprem determinada medida socioeducativa.

Percebe-se que o desenvolvimento da política socioeducativa só é possível devido ao progresso e à expansão do capitalismo na história em sua intensa necessidade de mediação com o trabalho, correspondente à ocorrência das lutas de classes, o que obriga o Estado capitalista a conceder direitos sociais na forma de benefícios - o que, por sua vez, atenua os conflitos de classes existentes, mas dificulta, em contrapartida, a formação de um processo revolucionário. ${ }^{26}$

A política socioeducativa legitima a existência e o poder de violência da força dominante, representada pelo próprio Estado capitalista, que priva de liberdade adolescentes que tiveram sua condição de existência negada, sendo alijados da cidadania burguesa, e que, contraditoriamente, depois de uma transgressão associada ao código penal, devem ter o direito de ser "ressocializados” na cultura do consumo, na primazia do mercado, e logo adestrados em "estabelecimentos educacionais que aplicam medidas socioeducativas” por meio do poder judiciário.

Esses adolescentes devem ser "ressocializados" por trabalhadores efetivos e temporários com determinado nível de especialização em tempos de acumulação flexível, em que tudo é fluido. Essa fluidez entra

${ }^{24}$ Um processo de emancipação vinculado a uma política emancipatória inclui uma política social de autorrealização e possibilidades de uma vida de satisfação pessoal para todos os indivíduos (GIDDENS, 1991).

${ }^{25}$ Relatório Geral das Medidas Socioeducativas do DF, elaborado pelo Sindsse/DF (LIMA, 2017).

${ }^{26}$ A democracia burguesa é limitada e não pode atender o principal interesse da classe trabalhadora por meio da opressão dos capitalistas (LENIN, 2010). 
em contradição com valores permanentes que devem ser passados aos adolescentes, como, em termos liberais, que o trabalho deve dignificar o homem. A atual fluidez do trabalho por meio da inserção do trabalho temporário nas medidas socioeducativas do DF é estabelecida pela própria relação de vida inconstante que esses jovens têm com o trabalho "ressocializador", o que contrasta com valores que deveriam ser permanentes, como a dignidade que o trabalho deveria proporcionar.

O movimento neoliberal de acumulação flexível, em sua fase de mundialização financeira, exclui do processo de cidadania esses adolescentes e, contraditoriamente, permite que eles sejam "ressocializados” por meio de políticas sociais precárias, como a socioeducativa no Distrito Federal. A execução desse serviço público estatal, quando não conta com servidores temporários, funciona com o mínimo de força de trabalho efetiva para executar as atividades operacionais básicas. ${ }^{27}$

Outra questão que demonstra a lógica do descompromisso dos gestores com a execução de uma política emancipatória está relacionada diretamente com a forma de tratamento aos trabalhadores e trabalhadoras responsáveis por executar os serviços, como lugares inadequados para acomodação dos agentes e da equipe técnica, assim como condições insalubres no espaço ao qual os adolescentes ficam circunscritos.

Essas condições propiciam um alto grau de propagação de doenças infectocontagiosas, ficando os servidores vulneráveis ao adoecimento físico, além das próprias relações de trabalho, que interferem diretamente na saúde mental dos trabalhadores encarregados da execução das medidas socioeducativas.

Tais fatores incidem sobre todos os trabalhadores do sistema socioeducativo; entretanto, tendem a pesar mais sobre os servidores temporários, porquanto estes recebem menores provimentos em relação aos

\footnotetext{
${ }^{27}$ Essas atividades são tarefas diárias, a exemplo de revistas aos adolescentes nos ambientes dos estabelecimentos, garantia de atendimento psicossocial e jurídico, confecção de relatórios, realização de atividades escolares e organização de visita de familiares, banho de sol, distribuição de refeições, vigilância e acompanhamento do adolescente para atendimento na rede externa, de acordo com o Relatório Geral das Medidas Socioeducativas do DF, elaborado pelo Sindsse/DF (LIMA, 2017).
} 
efetivos e ficam mais suscetíveis a situações de risco, com residual proteção trabalhista e respectivas garantias. Essas determinações tornam a implementação de uma concepção socioeducativa uma missão quase impossível, pois esta requer complexas mediações que são dificultadas pelas péssimas condições de trabalho impostas pelo Estado capitalista.

Nesse sentido, a praticidade e o retorno mais garantido, pautados em um número significativo de cumprimento de metas operacionais ou tarefas especializadas e simples, como o quantitativo de "escoltas", 28 abertura e fechamento de módulos, número de ligações e distribuição de refeições, tornam-se o objetivo da medida socioeducativa de internação em si. Não que essas atividades não sejam importantes, mas, em vista de situações precárias como o baixo efetivo de servidores, os diferentes modelos de contratação de força de trabalho e as frágeis condições para a sua realização, essas funções acabam ganhando a centralidade, em detrimento do resultado final, que é a própria "ressocialização do jovem”, reforçando, assim, um caráter meramente punitivista na aplicação da medida.

Nesse sentido, pode-se dizer que o sistema de trabalho nas unidades socioeducativas de internação no Distrito Federal se aproxima do modelo toyotista, ${ }^{29}$ exigindo do servidor polivalência e flexibilidade por meio da inserção de trabalho humano altamente qualificado, que até 2018 foi dividido entre efetivos e temporários e, ao mesmo tempo, ainda se fundamenta no sistema de resultados próprios da rigidez fordista, na qual a realização de tarefas simples, executadas individualmente e fragmentadas por cada setor, sem análise do todo e da finalidade, tornam-se as próprias metas de produtividade.

Essas atividades nas unidades socioeducativas de internação são setorizadas e muitas vezes sectarizadas; dessa forma, acabam tornando-se algo sem sentido para o servidor e para o adolescente, trazendo

${ }^{28}$ Termo da segurança pública do qual os agentes socioeducativos se apropriaram para se referirem ao acompanhamento de adolescentes em atividades externas.

${ }^{29}$ O objetivo do sistema toyotista era organizar uma metodologia de produção e de entrega mais ágil e precisa (PINTO, 2013). 
mais trabalho e precarização ao serviço público nos estabelecimentos educativos em que se estabelece, de fato, a política de atendimento socioeducativo no DF.

A divisão entre trabalhadores com vínculos contratuais distintos na execução do trabalho socioeducativo no Distrito Federal findou em julho de 2018, por determinação judicial impetrada pelo Sindsse/DF, em que o GDF foi obrigado a desligar todos os contratos temporários e convocar os servidores efetivos que aguardavam nomeação. No entanto, esse número não supriu a necessidade total do sistema socioeducativo e muito menos cobriu por completo a ausência dos servidores temporários. Ou seja, o número de temporários que saíram foi maior do que os efetivos nomeados.

O déficit da força de trabalho após a saída dos temporários e a efetivação de servidores públicos concursados chega a 40\% em algumas unidades, porquanto foram desligados 187 temporários, entre agentes socioeducativos e especialistas, de uma única vez. Entretanto, consolidou-se um ambiente institucional de trabalho mais seguro, pois os servidores efetivos, por possuírem um vínculo estável de trabalho com as medidas socioeducativas, conseguem defender em maior grau a não violação dos seus próprios direitos trabalhistas. ${ }^{30}$

De acordo com Lima (2017), o trabalho temporário representava um risco à integridade física dos adolescentes e dos trabalhadores, pois, em função do seu fraco vínculo institucional, os temporários, com medo de serem desligados, acabavam acatando todas as ordens dos superiores, executando-as sem analisar o grau de risco das atividades exigidas. Esses trabalhadores deveriam garantir o bom desempenho das atividades com um número reduzido de profissionais - em torno de dois ou quatro para acompanhar 30 a 40 adolescentes em um ambiente altamente favorável à ocorrência de brigas, motins, rebeliões, fugas etc.

O Sinase/2012 determina que um especialista (assistente social, pedagogo, psicólogo) deve acompanhar até 20 adolescentes e contar um agente socioeducativo para cada dois adolescentes. Nas atuais

\footnotetext{
${ }^{30}$ Informação verbal. Entrevista com o diretor sindical do Sindsse/DF.
} 
condições, constata-se que um especialista chega a atender até 40 jovens e um agente socioeducativo, até dez jovens.

As condições de precarização da política pública do Sinase/2012, especificamente na realidade do Distrito Federal, não se dão de forma isolada no contexto de desmantelamento que as políticas sociais vivenciam em tempos de canalização do fundo público para fins privados. Os direitos dos servidores que trabalham em políticas sociais, como a seguridade social, trabalho e educação, tornam-se os principais alvos de desmonte do Estado, que tende a entregar os serviços públicos não prioritários aos interesses privados de mercado, criando novos espaços de lucratividade.

Os ataques que as políticas sociais vêm sofrendo, incluindo a socioeducação, são reflexos e expressões da nova mundialização financeira do capital, em que esta representa a união de movimentos que se aliam para a centralização global de capitais, como a reestruturação produtiva, a desregulamentação dos Estados nacionais, o neoliberalismo e os contratos de trabalho precários. Essas tendências combinadas, que avançam sem um sólido contra-ataque da organização coletiva dos trabalhadores no Brasil, facilitam as ofensivas do Estado capitalista, deixando os trabalhadores disponíveis para as exigências do mercado em sua fase de acumulação flexível.

No século XXI, a classe trabalhadora sofre cada vez mais com o aumento da jornada e a intensidade do trabalho (DAL ROSSO, 2008b), a redução da taxa salarial e a desproteção social, perpassada pela crise da organização sindical, que não consegue realizar contraofensivas com adesão coesa dos trabalhadores.

Quanto ao serviço público, que tende a se apropriar dos modelos de gestão industrial e empresarial, os servidores públicos, que antes eram protegidos da lógica predatória capitalista, são cada vez mais colocados a serviço da valorização do capital. 
A superação do modelo de gestão burocrática pelo gerencial no serviço público ${ }^{31}$ coloca o trabalhador em uma constante busca para o alcance de infinitas metas, levando-os à exaustão e ao adoecimento. Tal busca é marcada pelas exigências de constante qualificação e polivalência, dada a disponibilização de escassos recursos e um ambiente de extrema competitividade entre os trabalhadores, em benefício do atendimento dos interesses da classe dominante, que tem ao seu dispor um exército de trabalhadores sobrantes e ávidos por uma vaga de emprego.

Nesse contexto, o trabalho temporário no serviço público, previsto constitucionalmente, mas utilizado de forma extrapolada em sua excepcional necessidade por governos neoliberais, tem sido utilizado para atender precariamente à população que necessita desses serviços e ainda divide e enfraquece os trabalhadores de uma determinada carreira,

${ }^{31}$ Como forma de romper com o modelo administrativo estatal, centralizado e burocrático, considerado arcaico por Bresser-Pereira (1999), e colocar o Brasil no cenário moderno e concorrencial monopolista do capital mundializado, esse autor defende uma reforma gerencial do Estado, respondendo às demandas de governo social-liberalista de Fernando Henrique Cardoso (FHC). Ainda para Bresser-Pereira (2010), a reforma gerencial do Estado implica uma legitimação do Estado Social. Ele afirma que o aumento das funções estatais em áreas relacionadas à administração e à execução de variados serviços sociais, como saúde e educação, e até na questão do meio ambiente, não suportava mais uma gestão burocrática, que, segundo seu ponto de vista, se torna dispendiosa demais para o fundo público. No entanto, ao contrário de Bresser-Pereira (2010) em sua tentativa de amenizar e legitimar a reforma gerencial do Estado, concorda-se, com Muniz (1995) e Behring (2008), que o Estado normalmente busca adequar sua administração às tecnologias estabelecidas no setor empresarial, em busca de mais valor, em detrimento da qualidade de vida dos trabalhadores, ou seja, estes recebem mais trabalho. Essas autoras afirmam que a reforma gerencial visa desresponsabilizar o Estado de suas funções sociais e voltá-lo exclusivamente às necessidades do mercado, dividindo-o entre funções essenciais e não essenciais do Estado. As funções essenciais seriam aquelas que promoveriam o bom controle e circulação de capitais; já as não essenciais seriam justamente os serviços sociais, ou seja, aquelas que atendem diretamente à classe trabalhadora, e que, portanto, garantem direitos. Enfim, acredita-se que a mudança de gestão burocrática para a gestão gerencial visa adequar o Estado à lógica de gestão de empresas pautadas na acumulação flexível. 
dificultando a solidariedade de classe diante dos diversos ataques para dividir e fragmentar os interesses da classe trabalhadora.

Nesse sentido, a divisão e a fragmentação dos trabalhadores de uma mesma carreira dificulta uma mobilização coletiva para a garantia e a conquista de novos direitos e, ainda, proporciona condições para um ambiente corporativista, que, por sua vez, resulta em possibilidades favoráveis à ocorrência de assédio moral entre trabalhadores que executam a mesma função pública, porém com vínculos diferenciados, como observado nesta pesquisa.

Os trabalhadores com vínculos precarizados tendem a ser mais cobrados e mais pressionados, sofrendo em dobro os efeitos dos desgastes das novas exigências do mercado de trabalho, com adoecimento físico e mental, além de reproduzirem uma lógica clientelista e patrimonialista no âmbito do Estado, podendo se tornar instrumentos de cooptação e controle dos interesses dominantes, em constante disputa pela direção social do Estado capitalista.

Nesse mote, o Estado capitalista democrático de direito, pautado em valores sociais fundamentais, como trabalho, respeito e dignidade, independentemente de credo, gênero e etnia, como apregoa a CF/88, cede espaço ao Estado capitalista neoliberal, em que os interesses públicos são levados por primazia ao âmbito privado e o trabalho temporário passa a ser uma das suas maiores manifestações.

O trabalho temporário deve ser visto como parte do conjunto de contrarreformas e reestruturação do Estado capitalista, em que a ascensão de um governo de extrema direita no Brasil, após o golpe de 2016, permitida por meio do fracasso da política econômica de conciliação de classes intentada pela era petista, buscará realinhar de forma ortodoxa e conservadora os interesses da classe dominante, de forma subordinada e dependente em relação aos interesses da elite econômica nacional e à ordem mundial financeirizada.

Assim, a nova tendência que se apresenta é a do trabalho precarizado, o que Antunes (2018) afirma ser a era do privilégio da servidão. Nesse contexto, estar trabalhando de forma precarizada, com jornadas de trabalho flexíveis e intensas, sujeitando-se a todas as formas de 
aviltamentos (como assédio moral, relações clientelistas, mandonismo, corporativismo), será uma regalia diante de um exército de trabalhadores desempregados, pauperizados e entregues à miséria no contexto da crise estrutural do capital. ${ }^{32}$

\section{Considerações finais}

O modo de produção capitalista impõe mudanças à organização social do trabalho e, por consequência, à vida daqueles que vivem ou sobrevivem dele, em prol de interesses privados. Essas mudanças e tendências não se dão pacificamente; muito pelo contrário, elas ocorrem em um tensionado campo de correlação de forças e lutas, em que o trabalho e o capital protagonizam uma disputa pelos benefícios que o trabalho pode produzir, seja para o alcance de interesses coletivos de emancipação humana, seja a para alienação e apropriação para interesses relacionados às vantagens individuais, como a acumulação e a centralização de capitais.

O Estado colabora para que o desenvolvimento capitalista ocorra da melhor forma possível, criando estratégias para controlar e submeter a força de trabalho aos interesses de acumulação capitalista.

Dessa forma, os dirigentes do Estado capitalista possuem um limite político de atuação para que a ordem social de exploração seja mantida, muito embora esse limite se alongue ou se reduza a partir do conflito de classe deflagrado pela rebeldia dos trabalhadores no que concerne ao acirramento da "questão social”. ${ }^{33}$

${ }^{32}$ Alves (2018, p. 148), pautado em Mészáros, em sua obra intitulada “A crise estrutural do capital”, afirma que a atual crise não é apenas mais uma crise cíclica do capital e sim uma crise de civilização, que não será resolvida apenas com a superação do capitalismo e sim com a superação do capital com mediações de segunda ordem. Assim, "a atual crise de civilização do capital se expressa na degradação do metabolismo social homem-natureza."

33 Todas as indicações possíveis sugerem que a expressão “questão social” tem história recente: seu emprego data de cerca de 190 anos. Começou a ser utilizada na terceira década do século XIX e foi divulgada até a metade daquela centúria por críticos da sociedade e filantropos situados nos mais variados espaços do espectro político. A expressão surge para dar conta do fenômeno mais evidente da história da Europa 
Nesse sentido, a classe trabalhadora exige do Estado, cada vez mais, proteção e serviços sociais públicos, como saúde, educação e medidas socioeducativas, de forma a atender às suas necessidades societárias de reprodução. Todavia, o limite para a conquista de novos direitos e a garantia dos existentes está cada vez mais restrito, porquanto o poder dominante, mundializado e financeirizado, tem reduzido o seu poder de concessão, a fim de promover a garantia da centralização de capitais.

Por isso, a social-democracia, um advento criado pelo Estado capitalista, nunca foi tão necessária, por permitir que os interesses do Estado não se voltem apenas para o desenvolvimento do capital financeiro, mas também, contraditoriamente, para o trabalho, no que se chama Estado burguês democrático de direito.

Tal processo vem se aguçando em virtude do recuo da força sindical, ocasionado, principalmente, pela fragmentação da capacidade de organização e de luta dos trabalhadores e trabalhadoras nesta era de acumulação flexível, que impõe ao trabalho jornadas ampliadas, intensas, flexíveis, sem proteção ou garantias. A generalização e a legalização de contratos de trabalho, como o intermitente, o terceirizado, o quarteirizado, o parcial e o temporário nos setores urbano e rural, público e privado, são expressões dessa heterogeneização, fragmentação e precarização do trabalho na era da acumulação flexível.

Essa tendência mundial acirra a competição entre os trabalhadores e mina a solidariedade de classe, ao tempo em que o individualismo de mercado se sobrepõe ao bem-estar coletivo, dificultando um combate coeso contra os interesses dominantes. Diante desse cenário, a luta pela emancipação humana, por meio da defesa e da efetivação da limitada social-democracia, tem se transformado em uma alternativa, embora residual e restrita se os objetivos forem, de fato, a emancipação dos sujeitos sociais, que se dará com a superação do capitalismo e do capital.

Ocidental, o fenômeno do pauperismo. Antiga é a desigualdade entre as várias camadas sociais, existindo desde sempre a polarização entre ricos e pobres (NETTO, 2006, p. 152). 
O trabalho temporário no serviço público não está dissociado dessas determinações - ao contrário, ele representa a real expressão de como o Estado capitalista tem minado a tendência social-democrata, pautada em valores sociais do trabalho e da dignidade humana, previstos pela $\mathrm{CF} / 88$.

O Estado capitalista neoliberal brasileiro tem se colocado como um guardião dos interesses financeiros mundializados; dessa forma, tem categorizado como essenciais as carreiras públicas que garantem os interesses de maior acumulação e como não essenciais as que promovem o bem-estar coletivo e o desenvolvimento humano, a exemplo da tecnologia, saúde e educação. Logo, as políticas sociais que executam serviços de interesse coletivo são mais atacadas e precarizadas, juntamente com o seu corpo de servidores.

Nessa tendência, são justamente os serviços públicos destinados à execução finalística das políticas sociais, como a política socioeducativa do DF, os mais suscetíveis à inserção de trabalho temporário que exceda a excepcional necessidade prevista pela CF/88, acarretando a precarização das condições de trabalho, as jornadas intensas e flexíveis e o adoecimento mental e físico. Nessa ordem, os trabalhadores temporários, juntamente com os terceirizados, tanto no serviço público como no privado, pertencem ao grupo de força de trabalho sujeito às relações destrutivas de ações corporativistas e de assédio moral, além de necessitarem se submeter a condições clientelistas e patrimonialistas.

O corpo de trabalhadores públicos, ao estarem dominados por essa lógica, transformam o potencial relativamente emancipatório das políticas sociais em reprodução dos interesses dos blocos de poder em constante disputa pela direção do Estado capitalista, arruinando a tendência da social-democracia do Estado de direito.

A partir da década de 1990, a força de trabalho temporário no serviço público do Distrito Federal, nas medidas socioeducativas, reforçou um modelo neoliberal. Atualmente, de acordo com o Sindsse/DF, após o desligamento dos temporários, o número de servidores públicos convocados não foi suficiente para suprir as demandas do sistema socioeducativo, o que permite um aumento da intensidade do trabalho 
dos servidores do setor. Em contrapartida, para o Sindsse, o vínculo estatutário de todos os servidores permitiu uma melhora das relações de trabalho e um fortalecimento da carreira contra os ditames do Estado capitalista neoliberal.

\section{Referências}

ALVES, Giovanni. O duplo negativo do capital: ensaio sobre a crise do capitalismo global. Bauru: Canal 6, 2018.

ALVES, Giovanni. O novo e (precário) mundo do trabalho: reestruturação produtiva e crise do sindicalismo. São Paulo: Boitempo, 2000.

ANTUNES, Ricardo. Adeus ao trabalho? Ensaio sobre as metamorfoses e a centralidade do mundo do trabalho. 16. ed. Rio de Janeiro: Cortez, 2015.

ANTUNES, Ricardo. O privilégio da servidão: o novo proletariado de serviços na era digital. São Paulo: Boitempo, 2018.

ANTUNES, Ricardo. Século XXI: A nova era da precarização estrutural do trabalho? In: DAL ROSSO, Sadi; FORTES, José Augusto Abreu Sá (org.). Condições de trabalho no limiar do século XXI. Brasília: Épocca, 2008.

ASP. DF é condenado a pagar adicional de insalubridade em grau máximo a servidor temporário. Tribunal de Justiça do Distrito Federal e dos Territórios, Brasília, dez. 2018. Disponível em: http://www.tjdft.jus.br/ institucional/imprensa/noticias/2018/dezembro/df-e-condenado-a-pagaradicional-de-insalubridade-em-grau-maximo-a-servidor-temporario. Acesso em: 9 jan. 2019.

BEHRING. Elaine. Brasil em Contra-Reforma: desestruturação do Estado e perda de direitos. 2. ed. São Paulo: Cortez, 2008. 
BORGES, Raiane Mousinho Fernandes; DUARTE JR., Ricardo. Contratação temporária: Análise de pressupostos e questões controversas. Âmbito Jurídico, Rio Grande, v. 12, n. 65, jun. 2009. Disponível em: http://ambito-juridico.com.br/site/index.php?artigo_id=6349\&n_ link=revista_artigos_leitura. Acesso em: 11 jul. 2019.

BRASIL. Lei $\mathrm{n}^{\circ}$ 12.594, de 18 de janeiro de 2012. Institui o Sistema Nacional de Atendimento Socioeducativo (Sinase) [...]. Diário Oficial da União, Brasília, Seção 1, 19 jan. 2012. Disponível em: http://www. planalto.gov.br/ccivil_03/_Ato2011-2014/2012/Lei/L12594.htm. Acesso em: 13 jul. 2019.

BRASIL. Lei n ${ }^{\circ}$ 13.429, de 31 de março de 2017. Altera dispositivos da Lei ${ }^{\circ}$ 6.019, de 3 de janeiro de 1974 [...]. Diário Oficial da União, Brasília, Seção 1, 31 mar. 2017. Disponível em: http://www.planalto.gov.br/ ccivil_03/_ato2015-2018/2017/lei/L13429.htm.Acessoem:24set.2018. BRASIL. Lei $n^{\circ}$ 6.019, de 3 de janeiro de 1974. Dispõe sobre o Trabalho Temporário nas Empresas Urbanas, e dá outras providências. Diário Oficial da União, Brasília, Seção 1, 4 jan. 1974. Disponível em: http://www.planalto.gov.br/ccivil_03/LEIS/L6019.htm. Acesso em: 20 set. 2018.

BRESSER-PEREIRA, Luiz Carlos. A reforma gerencial da administração pública no Brasil. In: PETRUCCI, Vera; SCHWARZ, Letícia (org.). Administração pública gerencial: a reforma de 1995: ensaios sobre a reforma administrativa brasileira no limiar do século XXI. Brasília: Editora UnB, ENAP, 1999.

BRESSER-PEREIRA, Luiz Carlos. Democracia, estado social e reforma gerencial. Rev. Adm. Empres., São Paulo, v. 50, n. 1, p. 112-116, mar. 2010. Disponível em: http://www.scielo.br/scielo.php?script=sci_ arttext\&pid=S0034-75902010000100009\&lng=en\&nrm=iso. Acesso em: 15 jul. 2019.

CARDOSO JR., José Celso (org.). Burocracia e ocupação no setor público brasileiro. Rio de Janeiro: IPEA, 2011. 
CARMO, Marlúcia Ferreira do. A nova face do menorismo: o extermínio da condição de sujeito de direitos dos adolescentes e jovens em medida socioeducativa de internação no Distrito Federal. 2015. 199 f. Tese (Doutorado em Política Social) — Universidade de Brasília, Brasília, 2015.

CHESNAIS, François. A mundialização do capital. São Paulo: Xamã, 1996. CONSELHO NACIONAL DO MINISTÉRIO PÚBLICO (CNMP). Um olhar mais atento às unidades de internação e semiliberdade para adolescentes. Relatório da Infância e Juventude - Resolução nº 67/2011. Brasília: Conselho Nacional do Ministério Público, 2013. Disponível em: http://www.cnmp.mp.br/portal/images/stories/Noticias/2013/ Arquivos/Relat\%C3\%B3rio_Interna\%C3\%A7\%C3\%A3o.PDF. Acesso em: 25 fev. 2019.

CORDEIRO, João; MOTA, Adriano. Trabalho Temporário: Fundamentos práticos da Lei n 6.019/1974. São Paulo: All Print, 2010.

DAL ROSSO, Sadi. A intensificação do trabalho - teoria e método. In: DAL ROSSO, Sadi; FORTES, José Augusto Abreu Sá (org.). Condições de Trabalho no limiar do século XXI. Brasília: Época, 2008a.

DAL ROSSO, Sadir. Mais Trabalho! A intensificação do labor na sociedade contemporânea. São Paulo: Boitempo, 2008b.

DF abre contratação de 337 médicos temporários; prazo é de até um ano. G1 DF, Brasília, 11 nov. 2016. Disponível em: substituir por: http:// g1.globo.com/distrito-federal/noticia/2016/11/df-abre-contratacao-de337-medicos-temporarios-prazo-e-de-ate-um-ano.html. Acesso em: 11 abr. 2019.

DI PIETRO, Maria Sylvia Zanella. Direito administrativo. 28 ed. São Paulo: Atlas, 2015. 
DISTRITO FEDERAL. Lei Complementar $n^{\circ}$ 840, de 23 de dezembro de 2011. Dispõe sobre o regime jurídico dos servidores públicos civis do Distrito Federal, das autarquias e das fundações públicas distritais. Diário Oficial do Distrito Federal, Brasília, n. 246, 26 dez. 2011. Disponível em: http://www.sinj.df.gov.br/sinj/Norma/70196/ Lei_Complementar_840_23_12_2011.html. Acesso em: 13 jul. 2019.

DISTRITO FEDERAL. Lei no 4.266, de 11 de dezembro de 2008. Dispõe sobre a contratação por tempo determinado para atender à necessidade temporária de excepcional interesse público [...]. Diário Oficial do Distrito Federal, Brasília, n. 247, 12 dez. 2008. Disponível em: http://www.tc.df.gov.br/sinj/Norma/59280/LEI-DF-2008-04266-AT. pdf. Acesso em: 11 jul. 2019.

DISTRITO FEDERAL. Lei no 5.240, de 16 de dezembro de 2013. Altera a Lei ${ }^{\circ} 4.266$, de 11 de dezembro de 2008, que dispõe sobre a contratação por tempo determinado para atender à necessidade temporária de excepcional interesse público [...]. Diário Oficial do Distrito Federal, Brasília, n. 247, 17 dez. 2013. Disponível em: http://www. sinj.df.gov.br/sinj/Norma/75950/Lei_5240_16_12_2013.html. Acesso em: 11 jul. 2019.

DISTRITO FEDERAL. Secretaria da Criança. Secriança Informa. Secretaria da Criança realiza processo seletivo simplificado: contrato temporário não é terceirização. Edição extra, jun. 2014a. Disponível em: http://www.crianca.df.gov.br/wp-conteudo/uploads/joomla/821a2 5c991cc8bf4c04298a8380765c3.pdf. Acesso em: 14 jul. 2019.

DISTRITO FEDERAL. Secretaria de Economia. Processo Seletivo Simplificado Secriança. 11 jun. 2014b (atualizado em 10 maio 2018). Disponível em: http://www.seplag.df.gov.br/secrianca-processo-seletivosimplificado/. Acesso em: 14 jul. 2019.

FERNANDES, Florestan. A revolução burguesa no Brasil: ensaio de interpretação sociológica. 2. ed. Rio de Janeiro: Zahar Editores, 1976. 
GIDDENS, Anthony. As consequências da modernidade. Tradução: Raul Fiker. São Paulo: Ed. Unesp, 1991.

HARVEY, David. Condição Pós-moderna. 24. ed. São Paulo: Loyola, 2013.

IAMAMOTO, Marilda Villela. Serviço Social em tempo de Capital Fetiche. São Paulo: Cortez, 2008.

KARPOV, Kleber. Contratos temporários da Secretaria da Criança podem perder auxílios transporte e refeição. Política Distrital, 16 fev. 2016. Disponível em: http://www.politicadistrital.com.br/2016/02/16/ contratos-temporarios-da-secretaria-da-crianca-podem-perder-auxiliostransporte-e-refeicao/. Acesso em: 21 out. 2018.

KATZ, Cláudio. Neoliberalismo, Neodesenvolvimentismo, Socialismo. São Paulo: Expressão Popular e Fundação Perseu Abramo, 2016.

LENIN, Vladimir Ilitch. O Estado e a Revolução [1917]. 2. ed. São Paulo: Expressão Popular, 2010.

LIMA, Walter Marques Siqueira de. Relatório Geral do Sistema Socioeducativo do Distrito Federal. Brasília: Sindicato dos Servidores da Carreira Socioeducativa do DF (Sindsse/DF), 14 de novembro de 2017. MAFRA FILHO, Francisco de Salles Almeida. Servidores públicos de contrato temporário. Revista Jus Navigandi, Teresina, ano 10, n. 559, 17 jan. 2005. Disponível em: https://jus.com.br/artigos/6147. Acesso em: 9 out. 2018.

MAIA, Flavia. Com contrato temporário, 286 servidores do Saúde da Família são demitidos. Correio Brasiliense, Brasília, 21 out. 2011. Disponível em: https://www.correiobraziliense.com.br/app/noticia/ cidades/2011/10/21/interna_cidadesdf,274907/com-contrato-temporario286-servidores-do-saude-da-familia-sao-demitidos.shtml. Acesso em: 23 nov.2018. 
MÉDICOS temporários ganham três vezes mais que concursados em início de carreira. Portal R7, Brasília, 20 set. 2013. Disponível em: https://noticias.r7.com/distrito-federal/medicos-temporarios-do-dfganham-tres-vezes-mais-que-concursados-em-inicio-de-carreira-dizmp-20092013. Acesso em: 11 mar. 2019.

MENORES têm ligação com 40\% dos homicídios do DF, mostram dados. G1 DF, Brasília, 21 abr. 2016. Disponível em: http://g1.globo. com/distrito-federal/noticia/2016/04/menores-tem-ligacao-com-40dos-homicidios-do-df-mostram-dados.html. Acesso em: 10 fev. 2019. MPDFT entra com ação contra presidente do sindicato da carreira socioeducativa. Ministério Público do Distrito Federal e Territórios, Brasília, 17 jun. 2016. Disponível em: http://www.mpdft.mp.br/portal/ index.php/comunicacao-menu/sala-de-imprensa/noticias/noticias-2016/ noticias-2016-lista/8570-mpdft-entra-com-acao-contra-presidente-dosindicato-da-carreira-socioeducativa. Acesso em: 11 jan. 2019.

MUNIZ, Nancy Aparecida Campos. A gestão dos servidores públicos pelo Estado. 1995. Dissertação (Mestrado em Sociologia) - Universidade de Brasília, Brasília, 1995.

NETTO, José Paulo. Capitalismo monopolista e Serviço Social. 5. ed. São Paulo: Cortez, 2006.

NUNES, Edson. A Gramática Política do Brasil: clientelismo e insulamento burocrático. 3. ed. Rio de Janeiro: Jorge Zahar; Brasília: ENAP, 2003.

OSÓRIO, Jaime. O Estado no Centro da Mundialização. São Paulo: Outras Expressões, 2014.

PAULO, Milton. Assédio moral no serviço público. Revista Jus Navigandi, Teresina, ano 23, n. 5518, 10 ago. 2018. Disponível em: https:// jus.com.br/artigos/67399. Acesso em: 13 fev. 2019.

PINTO, Geraldo Augusto. A organização do trabalho no século XX: taylorismo, fordismo e toyotismo. São Paulo: Expressão Popular, 2013. 
POULANTZAS, Nicos. O Estado, o poder, o socialismo. São Paulo: Paz e Terra, 2000.

PRUNES, José Luiz Ferreira. Terceirização do Trabalho. Curitiba: Juruá, 1995.

QUEIROZ, Ronaldo Pinheiro de. Decisão do STF abre porta para a burla aos concursos públicos. Consultor Jurídico, São Paulo, 30 ago. 2004. Disponível em: https://www.conjur.com.br/2004-ago-30/decisao_stf_ abre_porta_burla_aos_concursos. Acesso em: 23 out. 2018.

SINDICATO DOS SERVIDORES DA ASSISTÊNCIA SOCIAL E CULTURAL DO GDF (SINDSASC). Reunião dos servidores temporários da Secriança com o Sindsasc. Brasília: Sindsasc, 22 fev. 2016. Disponível em: http://sindsascgdf.org.br/post/124. Acesso em: outubro de 2018. SINDICATO DOS SERVIDORES DA CARREIRA SOCIOEDUCATIVA DO DISTRITO FEDERAL (SINDSSE/DF). Fim dos contratos temporários no sistema socioeducativo. Brasília: Sindsse/DF, 28 ago. 2018. Disponível em: http://www.sindssedf.org.br/fim-dos-contratostemporarios-no-sistema-socioeducativo/. Acesso em: 12 jul. 2019.

THIOLLENT, Michel. Crítica metodológica, investigação social e enquete operária. 5. ed. São Paulo: Polis, 1987.

VASAPOLLO, Luciano. O trabalho atípico e a precariedade. São Paulo: Expressão Popular, 2005.

WIEGERINCK, Jan. Trabalho Temporário na Prática. São Paulo: Makron Books, 1999. 
Capítulo 4

A participação social no campo da saúde do trabalhador e da trabalhadora

\section{Introdução}

Na história da Política de Saúde brasileira, a partir do reconhecimento da vinculação entre o processo de trabalho nos moldes do modo de produção e reprodução capitalista e os agravos à saúde dos(as) trabalhadores(as), foram construídas políticas públicas específicas para atender a essas 
peculiaridades, a exemplo da Política Nacional de Segurança e Saúde no Trabalho (PNSST), pelo Decreto n ${ }^{\circ}$ 7.602/2011 (BRASIL, 2011b), e da Política Nacional de Saúde do Trabalhador e da Trabalhadora (PNSTT), pela Portaria $n^{\circ}$ 1.823/2012 (BRASIL, 2012), destinadas a toda população - inclusive estagiária, desempregada, autônoma, cooperada ou aposentada.

A $8^{\text {a }}$ Conferência Nacional de Saúde de 1986 (BRASIL, 1987) foi considerada fundamental no processo de construção e consolidação do campo da saúde do(a) trabalhador(a) no Brasil e reafirmada na Constituição Federal de 1988 com a criação do Sistema Único de Saúde (SUS). Os princípios de universalidade, integralidade e controle social foram conquistas da luta da classe trabalhadora por meio dos espaços de reflexão e participação social. Os espaços das conferências, por exemplo, contribuíram com textos, debates, mesas redondas e trabalhos de grupos, tendo resultado na construção de seus relatórios finais.

Busca-se, nos espaços de controle democrático pertinentes à política de saúde dos(as) trabalhadores(as), a participação social, no sentido de aprofundar as discussões sobre os impactos do processo de trabalho sobre a saúde e de pensar em meios para o fortalecimento do SUS, da Reforma Sanitária, da Seguridade Social Pública e da garantia das condições econômicas e sociais dignas.

Esses elementos podem ser associados à mobilização da sociedade civil organizada e aos sindicatos, de maneira propositiva e articulada, construindo intercâmbio entre as esferas do poder público e da sociedade e democratizando conhecimentos e informações em saúde. Assim, espera-se que a autonomia do trabalhador sobre sua saúde seja objeto de diálogo entre os setores públicos e privados. O controle democrático na Política Nacional de Saúde - o SUS - e na PNSTT se concretiza nos espaços dos conselhos, das comissões e das conferências.

Aqui serão apresentadas informações concernentes aos relatórios finais das Conferências Nacionais de Saúde do(a) Trabalhador(a) de 1986, 1994, 2005 e de 2014. O objetivo deste estudo é identificar as principais deliberações realizadas nesses momentos, com enfoque naquelas relacionadas às temáticas da proteção social e do controle democrático e à sua concretização na PNSTT. 
Dar-se-á continuidade a essas reflexões considerando as transformações no mundo do trabalho na contemporaneidade, bem como seus rebatimentos na organização da classe trabalhadora. Pressupõe-se que a PNSTT resulte da intensa mobilização dessa classe no sentido de adquirir visibilidade e que, em consequência, atue concretamente na redução de acidentes e doenças relacionadas ao trabalho, mediante ações de promoção, reabilitação e vigilância em saúde, bem como na luta pela garantia dos direitos sociais básicos para a existência humana.

\section{Precarização estrutural do trabalho e rebatimentos na organização da classe trabalhadora}

Este tópico compreende as mudanças no mundo do trabalho no contexto da ofensiva neoliberal, da crise estrutural e da mundialização do capital financeiro, plasmado na reestruturação produtiva, que é caracterizada, principalmente, pela flexibilização e desconcentração do trabalho físico. Tais elementos repercutem na organização da classe trabalhadora em virtude da sobreposição de interesses econômicos aos interesses sociais - reflexo da contradição existente entre capital e trabalho. Disso decorre uma conjuntura de destruição das legislações sociais protetoras do trabalho, ocasionando agravos à saúde dos(as) trabalhadores(as) e a visível e progressiva exploração do trabalho no Brasil em todos os níveis.

Considerando os apontamentos de Barbosa (2007, p. 40) acerca do trabalho precarizado e desprotegido, entende-se que a insegurança frente aos direitos trabalhistas e previdenciários submete o trabalhador a condições de vida arriscadas e à cruel dominância da concorrência no mercado, e que isso ocorre sem ações coletivas de enfrentamento e sem segurança de cobertura social no presente e futuro - ou no momento em que o trabalhador não mais dispuser de sua força de trabalho. Antunes (2015), em sua obra “Adeus ao trabalho?”, lançada em 1995, já reiterava esse entendimento, afirmando que os grupos capitalistas dominantes desejam, de todo modo, fazer proliferar as distintas formas de trabalho precarizado, representado pelo trabalho voluntário, 
subcontratado e terceirizado, e pelo empreendedorismo como resposta à crise estrutural do capital.

Para Alves (2005), na particularidade brasileira, as mudanças no campo do trabalho, aliadas ao neoliberalismo ${ }^{1}$ na década de 1980 e, em especial, na década seguinte, remodelaram o mundo do trabalho no país por meio do desemprego estrutural, da precariedade de emprego e da baixa tendencial dos salários. Aliadas às alterações laborais tanto no campo da reorganização do trabalho, mediante a redução da força de trabalho e a inserção de maquinarias, quanto na expansão do trabalho informal -, as reformas trabalhistas e previdenciárias reforçaram a insegurança e angústia em relação à manutenção do emprego e aumentaram a intensificação da exploração da classe trabalhadora para os que permanecem empregados. Isso sem contar os amplos contingentes populacionais que ficam descobertos nas situações de adoecimento ou desemprego. Segundo Antunes (2015, p. 266), “[...] quando os empregos se reduzem, aumenta o desemprego, a degradação social e a barbárie.”

Reitera-se que, no contexto de flexibilização do trabalho e do mercado, a mobilidade geográfica transcendendo fronteiras, a ampliação do trabalho informal e a desregulamentação trabalhista, o processo de trabalho no modo de produção e reprodução capitalista tornou-se ainda mais precarizado. Estes são elementos que afetam a estrutura da classe trabalhadora, suas formas de organização, capacidade de intervenção e acesso aos direitos sociais, refletindo nas condições de vida e trabalho e repercutindo no agravamento da questão social. Na particularidade da terceirização, o empresariado objetiva a obtenção do lucro por meio da redução de custos. Em contraposição,

1 O neoliberalismo tem sido colocado em prática por meio de privatizações de empresas estatais e serviços públicos, além da desregulamentação ou criação de novas regulamentações no campo das relações trabalhistas e comerciais, flexibilizando-as e propiciando o aumento da exploração da mão de obra da classe trabalhadora, na tentativa de transferência das responsabilidades do Estado para o setor privado (MORAES, 2001). 
[...] estudos mostram que a terceirização tem-se mostrado nefasta para a vida e a saúde dos trabalhadores: os salários são mais baixos, a rotatividade é maior, as condições de trabalho são mais precárias, os riscos de acidentes e doenças são maiores, as empresas aparecem e desaparecem, deixando trabalhadores sem qualquer cobertura e os trabalhadores, que não pertencem aos sindicatos mais organizados, ficam desprotegidos. (BRASIL, 2015, p. 98).

Características novas surgem nesse desenrolar. Em decorrência de tais alterações, nasce uma classe trabalhadora mais fragmentada e desorganizada espacialmente, ${ }^{2}$ mais heterogênea e mais diversificada mundialmente (ANTUNES; ALVES, 2004), ou complexificada (ANTUNES, 2015). Dentre os rebatimentos na organização da classe trabalhadora, a ruptura e desconstrução da alienação/estranhamento e construção de uma consciência de classe são considerados os principais objetivos a serem alcançados no contexto da contradição capital e trabalho. Para Antunes e Alves (2004, p. 348), “a alienação/estranhamento é ainda mais intensa nos estratos precarizados da força humana de trabalho, que vivenciam as condições mais desprovidas de direitos e em condições de instabilidade cotidiana [...].”

A consciência de classe pode ser construída e desenvolvida por meio do entendimento sobre o processo de dominação e/ou subordinação contido na relação capital e trabalho. Nesse caminho, parte-se do pressuposto da existência de duas classes sociais fundamentais e antagônicas e da ideia de que ou se detém a força de trabalho para ser vendida no mercado, ou os meios de produção. É interessante aliar esse entendimento à percepção de sujeito necessariamente protagonista da sua história e do fazer histórico mais amplo.

2 Com a mundialização do capital e a livre circulação de capitais, alterou-se o nível de concentração dos trabalhadores nos ambientes laborais. Por exemplo, muitos trabalham em casa ou exercem atividade por livre demanda, influenciando na consciência de classe, na organização e na experiência de luta. 
Segundo Pereira-Pereira (2016), a prova mais clara da perda de substância analítica da crise e de como os meios políticos têm sido utilizados para a minimização dessa crise está no discurso neoliberal dominante, que ocasiona a perda gradativa do domínio da compreensão de categorias fundamentais para a concepção de sociedade e do imbróglio do atual sistema do capital. Isso significa que os termos classe social, poder de classe e conflito social, ou então, burguesia, pequena burguesia e classe trabalhadora, que definem a posição dos coletivos populacionais pela sua posição na estrutura de classes, estão sendo esquecidos nas reflexões.

Segundo Coutinho (1999), em uma sociedade de classes, as ideologias disputam consciências, e a classe que detém os meios de produção tende a deter também os meios para universalizar sua visão de mundo e suas justificativas ideológicas a respeito das relações sociais de produção que garantem sua dominação econômica.

Além desses fatores, o cenário de forte recessão e destruição dos direitos alcançados e construídos legitimamente pela sociedade (processo reforçado pelo aumento do desemprego) dificulta o embate, porque o trabalhador sabe do risco iminente da perda do emprego e, consequentemente, da renda. O tópico que segue aborda o engajamento da população trabalhadora no espaço de debate sobre a relação saúde e trabalho nas mencionadas Conferências Nacionais de Saúde do(a) Trabalhador(a).

\section{Percurso teórico-metodológico e controle democrático no campo da saúde do(a) trabalhador(a)}

A saúde do(a) trabalhador(a), ${ }^{3}$ enquanto campo da saúde pública, tem sido estudada a partir da compreensão do caráter histórico-social do processo saúde-doença, “que discute a limitação da concepção

3 O conceito de saúde do/a trabalhador/a está interligado à “[...] análise do processo de trabalho, a partir da concepção marxiana, e o trabalhador como ser social de intervenção desse processo em torno da luta pelo direito à saúde e condições de trabalho que não o agridam” (OLIVAR, 2010, p. 316). 
biológica da doença e a influência do caráter histórico e social no processo de adoecimento” (ROCHA; DAVID, 2015, p. 130; LAURELL, 1982). Aliada a essa compreensão, a crítica dialética reforça que as condições de vida e trabalho são expressões das condições materiais produzidas socialmente, ou seja, são relações condicionadas pela produção (MARX; ENGELS, 2007). Com base nesse entendimento, é lícito dizer que as condições sociais e econômicas influenciam na saúde e doença, ou, conforme Rocha e David:

\begin{abstract}
Vale ressaltar que saúde vai além de um fato biológico-natural e do emprego de esquemas epidemiológicos. Faz parte da convivência do indivíduo em sociedade e ao acesso às redes socioeconômicas e de serviços essenciais. Isto é, o contexto social e a história de vida individual e da coletividade irão influenciar positiva ou negativamente na saúde, a qual é um fenômeno eminentemente humano. (ROCHA; DAVID, 2014, p. 134).
\end{abstract}

A partir desses elementos, são apresentados e discutidos os espaços de participação social na realidade brasileira no contexto da relação trabalho-saúde-doença, o que pressupõe articular o desenvolvimento de tal temática com a organização da classe trabalhadora e os espaços de construção e contradição que envolvem a participação.

Pereira-Pereira (2008) esclarece que o controle democrático consiste no controle, pelos cidadãos, da política pública, regulada e frequentemente provida pelo Estado, visto que ela engloba demandas, decisões e escolhas privadas. Esse conceito se diferencia do controle social, porque não permite designar o controle do Estado sobre a sociedade, e sim o inverso. O controle democrático, então, articula-se com a atuação da sociedade civil organizada no sentido de contribuir para que as demandas e interesses da coletividade se efetivem.

Os desafios e embates políticos relacionados aos distintos interesses que permeiam a participação nos conselhos e conferências são parte do processo de construção da sociedade contemporânea pós-processo 
de abertura democrática. A possibilidade de participação ativa da classe trabalhadora nos espaços de decisão, como a gestão do SUS, contribui para a constituição de meios de direção intelectual e moral. Para Coutinho (1999), a socialização da política altera "uma complexa rede de organizações coletivas, de sujeitos políticos de novo tipo, com um papel mais ou menos decisivo na correlação de forças que determina o equilíbrio de poder” (COUTINHO, 1999, p. 27-28). Por outro lado, a socialização política não pode caminhar junto à apropriação privada dos bens socialmente produzidos.

Conhecendo-se o conjunto de fatores necessários à construção de uma nova ordem societária sem exploração de classe, Coutinho (1999) apresenta as objetivações institucionais necessárias à realização do valor universal da democracia como uma resposta a essa possibilidade. Antes, esse valor seria parte integrante do ser genérico do homem, composto pelo trabalho objetivado, pela socialização da riqueza socialmente produzida, pela universalidade, em oposição à alienação, pela consciência e pela liberdade.

Nesse espaço de contradições, Lacaz e Flório (2009, p. 4) fazem a análise de que, apesar do avanço na direção do controle social democrático sob o Estado capitalista, o que se vem observando é a falta de articulação entre as bases representativas. Para os autores, essa falta de articulação acontece principalmente pela ausência ou insuficiência de informações necessárias às tomadas de decisões, e pelo clientelismo ${ }^{4}$ que se forma a partir de demandas fragmentadas e particularistas.

A participação da sociedade civil na gestão das políticas públicas não foi uma medida voluntária e de concessão do Estado, mas uma conquista da classe trabalhadora resultante das reivindicações ocorridas nas décadas de 1970 e 1980 no Brasil, em oposição ao governo autoritário da ditadura civil-militar (1964-1985) imposta no país - regime que tinha, muitas vezes, posições contrárias aos interesses e necessidades da população.

4 No sentido de privilegiar uma clientela. 
A partir dos desdobramentos do movimento da Reforma Sanitária Brasileira e da ressonância dos seus pressupostos na $8^{\text {a }}$ Conferência Nacional da Saúde (1986), foi possível construir as bases para um novo sistema público de saúde pautado na universalidade, equidade e integralidade, estrategicamente organizado pelas diretrizes da descentralização, regionalização, hierarquização e participação social, sendo o direito social à saúde compreendido como responsabilidade do Estado, e a sua execução, garantida por meio de políticas públicas e sociais. Inclui-se, como seu atributo, alcançar o patamar de sistema único de saúde estatal, gratuito, universal e de qualidade para toda a população (BRAVO; MENEZES, 2011).

Para viabilizar a representação da sociedade na esfera governamental, foram criados conselhos e comissões, posteriormente respaldados no texto constitucional. Com o processo de abertura política na sociedade brasileira na década de 1980, pós-ditadura civil-militar, além da promulgação da CF/88, ocorreu a aprovação da Lei n ${ }^{\circ}$ 8.142, de 28 de dezembro de 1990, que dispõe sobre a participação da comunidade na Gestão do Sistema Único de Saúde (SUS) e sobre as transferências intergovernamentais de recursos financeiros na área da saúde e dá outras providências (BRASIL, 1990b). Houve também a aprovação da Lei Orgânica de Saúde (LOS), pela Lei no 8.080, de 19 de setembro de 1990, que regulamenta e define os princípios e a formatação do SUS, e, no que tange à participação social, há o estabelecimento de duas instâncias institucionalizadas, os Conselhos e as Conferências de Saúde (BRASIL, 1990a).

O controle social democrático do SUS é exercido pelo Conselho Nacional de Saúde; os Conselhos Estaduais e Municipais terão representantes entre os usuários (50\%), os trabalhadores da saúde (25\%) e os representantes de prestadores de serviços de saúde (25\%), tanto públicos como privados (LACAZ; FLÓRIO, 2009, p. 4). 
A Comissão Intersetorial de Saúde do Trabalhador (Cist) está prevista no art. 12 da Lei Orgânica de Saúde no 8.080/90, ${ }^{5}$ com o propósito de assessoramento dos conselhos de saúde, no que se refere à temática de Saúde do(a) Trabalhador(a). Portanto, a Cist é subordinada aos conselhos de saúde e não possui caráter deliberativo. Ademais, relacionada à Política Nacional de Segurança e Saúde no Trabalho (PNSST), encontra-se a Comissão Tripartite de Saúde e Segurança no Trabalho, que trata da estrutura de promoção da segurança e saúde no trabalho, bem como da elaboração de um plano de segurança e saúde no trabalho que articule as ações de promoção, proteção, prevenção, assistência, reabilitação e reparação da saúde do trabalhador.

O diálogo entre os diversos setores envolvidos contribui significativamente para o aperfeiçoamento do sistema nacional de segurança e saúde no trabalho, permitindo desenvolver mecanismos que pretendem alcançar as distintas demandas da população trabalhadora. Os espaços dos conselhos, das comissões e das conferências objetivam introduzir na lógica estatal uma nova dinâmica de democratização da esfera pública, tornando-a mais próxima das demandas da população.

Ao influir nas políticas e nas decisões de gestão, a sociedade e o Estado passam a estabelecer uma relação de corresponsabilidade frente ao interesse público, em oposição à cultura patrimonialista, marca da formação sócio-histórica brasileira. Entretanto, o processo participativo deve se basear na construção de consensos e no pressuposto da condição de igualdade e liberdade nas deliberações, conforme pressupõem as diretrizes do SUS.

Nesse contexto, produz-se a análise dos relatórios finais das Conferências Nacionais de Saúde do(a) Trabalhador(a) (CNST) de 1986, 1994, 2005 e 2014, que são considerados frutos das disputas travadas

5 “Art. 12. Serão criadas comissões intersetoriais de âmbito nacional, subordinadas ao Conselho Nacional de Saúde, integradas pelos Ministérios e órgãos competentes e por entidades representativas da sociedade civil. Parágrafo único. As comissões intersetoriais terão a finalidade de articular políticas e programas de interesse para a saúde, cuja execução envolva áreas não compreendidas no âmbito do Sistema Único de Saúde (SUS)” (BRASIL, 1990a). 
nas pré-conferências estaduais, ${ }^{6}$ das quais, por sua vez, além do debate sobre a questão central saúde/trabalho e seus encaminhamentos políticos, resultam discussões dos problemas locais e regionais que, ao serem encaminhadas à reunião nacional, propiciaram a identificação do controle democrático nesse campo.

A investigação ocorreu por meio de pesquisa qualitativa dos dados, que corresponde a um espaço mais profundo de compreensão das relações, dos processos e dos fenômenos, e da revisão bibliográfica, no contexto da relação trabalho, saúde e doença e análise documental dos relatórios finais das CNST. Os dados propiciaram relacionar as deliberações e propostas com a sua concretização na Política Nacional de Saúde do Trabalhador e da Trabalhadora (PNSTT). Segue mais à frente um quadro com essas informações sistematizadas.

\subsection{As Conferências Nacionais de Saúde do(a) Trabalhador(a)}

Para Souza (2013, p. 57), as conferências dispõem de alguns pontos em comum, a saber: a) são convocadas com caráter consultivo ou deliberativo pelo Poder Executivo de cada nível de governo, por meio de decreto que traz o tema do debate e o órgão responsável pela organização do processo (como disposto na Lei no 8.142, de 28 de dezembro de 1990); b) quando previsto em lei, o próprio conselho setorial pode fazer o chamamento à participação; c) os órgãos considerados responsáveis (como o Ministério da Saúde) publicam portarias que definem a comissão organizadora, os objetivos, o período e a forma de realização.

${ }^{6}$ Nesses momentos de troca, são escolhidos os delegados como representantes dos atores sociais de cada um dos estados em que as pré-conferências se realizam. 
Quadro 1: Informações gerais sobre as Conferências Nacionais de Saúde do(a) Trabalhador(a)

\begin{tabular}{|c|c|c|c|}
\hline Conferência & Data e local & Temática & Participantes \\
\hline $\begin{array}{l}\text { 1a Con- } \\
\text { ferência } \\
\text { Nacional } \\
\text { de Saúde } \\
\text { do Traba- } \\
\text { lhador }\end{array}$ & $\begin{array}{l}\text { 01/12 a } \\
\text { 05/12/1986, } \\
\text { em Brasília }\end{array}$ & $\begin{array}{l}\text { Saúde } \\
\text { como } \\
\text { direito do } \\
\text { cidadão } \\
\text { e dever } \\
\text { do Esta- } \\
\text { do }\end{array}$ & $\begin{array}{l}\text { Total: } 526 \text { pessoas } \\
\text { Delegadas: } 399 \\
\text { Observadoras: } 127 \\
\text { Debatedoras: } 55 \\
\text { Comissão organi- } \\
\text { zadora: } 75\end{array}$ \\
\hline $\begin{array}{l}2^{\text {a Con- }} \\
\text { ferência } \\
\text { Nacional } \\
\text { de Saúde } \\
\text { do Traba- } \\
\text { lhador }\end{array}$ & $\begin{array}{l}\text { 13/03 a } \\
\text { 16/03/1994, } \\
\text { em Brasília }\end{array}$ & $\begin{array}{l}\text { Cons- } \\
\text { truindo } \\
\text { uma Po- } \\
\text { lítica de } \\
\text { Saúde do } \\
\text { Traba- } \\
\text { Ihador }\end{array}$ & $\begin{array}{l}\text { Total: } 900 \text { pessoas } \\
\text { Delegadas: } 563\end{array}$ \\
\hline $\begin{array}{l}3^{\text {a Con- }} \\
\text { ferência } \\
\text { Nacional } \\
\text { de Saúde } \\
\text { do Traba- } \\
\text { lhador }\end{array}$ & $\begin{array}{l}24 / 11 \text { a } \\
27 / 11 / 2005, \\
\text { em Brasília }\end{array}$ & $\begin{array}{l}\text { Traba- } \\
\text { Ihar, sim! } \\
\text { Adoecer, } \\
\text { não! }\end{array}$ & $\begin{array}{l}\text { Total: } 2.100 \text { pes- } \\
\text { soas } \\
\text { Delegadas: } 1.409\end{array}$ \\
\hline $\begin{array}{l}4^{a} \text { Con- } \\
\text { ferência } \\
\text { Nacional } \\
\text { de Saúde } \\
\text { do Traba- } \\
\text { lhador }\end{array}$ & $\begin{array}{l}\text { 15/12 a } \\
\text { 18/12/2014, } \\
\text { em Brasília }\end{array}$ & $\begin{array}{l}\text { Saúde do } \\
\text { Traba- } \\
\text { Ihador } \\
\text { e da } \\
\text { Traba- } \\
\text { Ihadora, } \\
\text { direito de } \\
\text { todos e } \\
\text { todas e } \\
\text { dever do } \\
\text { Estado }\end{array}$ & $\begin{array}{l}\text { Total: } \\
\text { 1.399 pessoas } \\
\text { Delegadas: } 991 \\
\text { Convidadas: } 56 \\
\text { Palestrantes: } 33 \\
\text { Coordenadores e } \\
\text { relatores: } 52 \\
\text { Representantes } \\
\text { das comissões: } 37 \\
\text { Acompanhantes } \\
\text { das pessoas com } \\
\text { deficiência: } 12 \\
\text { Equipe de apoio: } \\
218\end{array}$ \\
\hline
\end{tabular}

Fonte: Elaboração própria, a partir das informações obtidas nos relatórios finais das Conferências Nacionais de Saúde do(a) Trabalhador(a). 
No caso das conferências temáticas, nas quais se insere o campo da saúde do(a) trabalhador(a), não existe ato administrativo (portaria, decreto) que as autorize. Essas são deliberadas nas Conferências Nacionais de Saúde, ou seja, dispostas nos seus relatórios finais. Como pode ser observado no quadro anterior, até o momento foram realizadas 4 (quatro) Conferências Nacionais de Saúde do(a) Trabalhador(a). A $4{ }^{\text {a }}$ CNST, especificamente, foi deliberada pelo pleno.

\subsection{1. $1^{a}$ Conferência Nacional de Saúde do(a) Trabalhador(a) - 1986}

A $1^{\text {a }}$ Conferência Nacional de Saúde do(a) Trabalhador(a), ocorrida em Brasília no período de $1^{\circ}$ a 5 de dezembro de 1986, possibilitou dar continuidade às discussões iniciadas no momento da $8^{a}$ Conferência Nacional da Saúde, no sentido de relacionar saúde, trabalho e democracia.

O momento da $1^{\mathrm{a}}$ CNST foi construído coletivamente por meio das pré-conferências estaduais e municipais, no sentido de que as questões gerais, contempladas no temário central, fossem efetivamente circunstanciadas para a realidade de cada região, possibilitando abarcar as prioridades de cada área. Assim, foi realizado esse momento de reflexão conjunta e debates em 20 (vinte) estados (BRASIL, 1986). Os temas abordados nos estados foram organizados em três temas centrais: 1) diagnóstico da situação de saúde e segurança dos trabalhadores; 2) novas alternativas de atenção à saúde dos trabalhadores; 3) Política Nacional de Saúde dos Trabalhadores.

O diagnóstico da situação de saúde e segurança dos trabalhadores levou em conta a própria formação da sociedade brasileira e a implantação do capitalismo no país como fatores importantes para a compreensão do quadro da "dramática situação da saúde do trabalhador” (BRASIL, 1986, p. 7). Dessa forma,

[...] estando o Estado sempre a serviço da classe dominante, situação essa acentuada nos últimos 21 anos de ditadura, com brutal espoliação e amordaçamento das classes dominadas. Assim, a saúde do trabalhador 
sempre foi e continua sendo, até o presente, subordinada aos interesses do capital nacional e internacional. (BRASIL, 1986, p. 7).

Os elementos constituintes do relatório final da $1^{\text {a }}$ CNST demonstram firme posicionamento político, mediante uma análise crítica do capitalismo e do reconhecimento da sua vinculação com as condições de vida e de trabalho da classe trabalhadora brasileira. O relatório aborda a condição de desemprego articulada à categoria do Exército Industrial de Reserva, de Marx, quando afirma: "Neste perverso processo de desenvolvimento do capitalismo no Brasil, é criado um exército industrial de reserva que torna o trabalhador em simples peça de reposição, o que explica o descaso para com a sua saúde” (BRASIL, 1986, p. 7).

Ainda no relatório, assevera-se que: "Tal fato torna o trabalho um fator de risco porque a preocupação do capital é com o lucro e não com o indivíduo” (BRASIL, 1986, p. 7). Além disso, a consciência de que é necessário superar esse modo de produção que explora e degrada a força de trabalho também foi objeto de reflexão: “A superação das atuais condições materiais de vida e saúde a que estão submetidos os trabalhadores e o povo somente se dará com a implantação do socialismo" (BRASIL, 1986, p. 8). As análises desencadeadas são resultado do contexto sociopolítico da época, que buscava o rompimento com o autoritarismo do Estado. A análise da especificidade do trabalho urbano e rural também foi objeto de análise na $1^{\text {a }}$ CNST, aliada ao contexto social:

A situação do trabalhador rural, muito mais dramática do que do trabalhador urbano, tem origem na concentração da terra nas mãos dos latifundiários; na política agrícola favorecendo a exportação e os grandes produtores, não priorizando a produção do alimento básico nas leis discriminatórias, estando, por conseguinte o trabalhador rural submetido a um tratamento diferencial em todos os níveis. Consequentemente, a transformação da estrutura fundiária do país torna-se fundamental para melhorar as condições de saúde do trabalhador rural. (BRASIL, 1986, p. 7). 
O campo da saúde do(a) trabalhador(a) avança no reconhecimento das particularidades e da totalidade da vida social, política e econômica. Trata-se de um entendimento distinto da saúde ocupacional e da medicina do trabalho. Constatou-se naquele momento, em 1986, que a legislação brasileira era “[...] dúbia, mal elaborada, sujeita a interpretações, subordinada principalmente aos interesses da classe dominante, baseada em modelos importados” (BRASIL, 1986, p. 9), como também, no que concerne às condições de saúde e trabalho,

[...] mercantiliza o risco através da sua monetarização, não atende as necessidades do trabalhador e sua proteção no processo de mudança tecnológica (por exemplo, quanto ao ritmo de trabalho). Restringe o número das doenças profissionais sem atender aos agravos decorrentes da introdução de novos agentes no processo produtivo. (BRASIL, 1986, p. 9).

Partindo desses pressupostos, foram levantadas recomendações/ propostas no momento da $1^{\text {a }} \mathrm{CNST}$, divididas nos três temas centrais anteriormente citados. No que concerne à constituição de uma Política Nacional de Saúde dos Trabalhadores, procedeu-se ao levantamento dos direitos básicos de saúde do(a) trabalhador(a), dos elementos propositivos para a integração da política do(a) trabalhador(a) com a política nacional de saúde e da integração desta com as demais políticas do Estado (no âmbito da previdência, da saúde e do trabalho/emprego).

Como parte dos direitos básicos de saúde do(a) trabalhador(a) relacionados com a temática proteção social e controle democrático, foram elencados, dentre outros fatores, a necessidade de ampliação da participação nas decisões referentes à saúde do(a) trabalhador(a), dentro e fora da empresa; o direito à estabilidade no emprego, abrangendo as necessidades de vida e trabalho; o direito a recusar-se a trabalhar em locais insalubres ou perigosos; o direito à alimentação nos locais de trabalho e ao recebimento de uniformes, financiados exclusivamente pelos empregadores; a garantia de creches nos locais de trabalho e de moradia; a ampliação da duração da licença-gestação para seis meses, 
a fim de garantir o direito à amamentação, assegurando-se o retorno ao emprego; o direito à posse da terra aos que nela vivem e trabalham, bem como o direito ao crédito rural, e à assistência técnica por parte dos órgãos públicos, ao apoio, à comercialização dos produtos agrícolas, à aposentadoria dos trabalhadores rurais e pescadores aos 45 anos, sem distinção de sexo; a garantia da revisão e ampliação das situações e funções que dão direito à aposentadoria; o direito à assistência integral à saúde, gratuita, universal e equânime a todo cidadão, independentemente do vínculo empregatício, credo, idade, sexo, cor, ideologia etc.; e o direito à aposentadoria aos 25 anos de trabalho para os trabalhadores e pessoas com deficiência (BRASIL, 1986).

Para a integração da política do(a) trabalhador(a) com a política nacional de saúde, o relatório propõe inserir a saúde do(a) trabalhador(a) no campo da saúde pública, porquanto a construção dessa política faz parte do SUS, sob controle dos trabalhadores (BRASIL, 1986). Tais propostas estão em conformidade com a posterior promulgação da CF/88 e da Lei Orgânica da Saúde.

Na articulação dessa política com as demais políticas de Estado, pressupõe-se a articulação e estabelecimento de uma política científica e tecnológica para usufruto da classe trabalhadora; uma política de transporte de qualidade; uma política de produção e abastecimento de alimentos básicos; uma política de educação pública gratuita e universal; o controle e referendo do desmatamento, instalações de barragens e agroindústrias pelas comunidades e entidades locais; a imediata suspensão do pagamento da dívida externa, até que a Nação se pronuncie mediante ampla consulta e participação popular, dada a necessidade de superar a dissociação entre as políticas econômica e social; e a descriminalização do aborto, dentre outros pressupostos (BRASIL, 1986).

Observa-se que a maioria das deliberações anteriormente elencadas ainda são objeto de disputa entre o Estado, a sociedade e o mercado, embora se tenha avançado na incorporação jurídico-formal das reivindicações sobre saúde do trabalhador na CF/88 e no início de um processo de elaboração de uma Política Nacional de Saúde do(a) Trabalhador(a). 
A $2^{\text {a }}$ CNST, realizada em Brasília, de 13 a 16 de março de 1994, teve como tema central "Construindo uma política de saúde do trabalhador” e representou um momento decisivo no sentido da formulação de uma política pública de saúde do(a) trabalhador(a) (BRASIL, 1994). Apesar do momento pós-promulgação da CF/88, dos avanços referentes à organização do Sistema Único de Saúde e da definição da área da saúde do(a) trabalhador como parte da saúde pública, ${ }^{7}$ as políticas sociais públicas enfrentaram dificuldades em vista da implantação do projeto neoliberal e do contexto de reforma do Estado, o que foi considerado um agravante para a $2^{\mathrm{a}} \mathrm{CNST}$.

O período da realização da $2^{\text {a }}$ CNST foi marcado pelos desdobramentos da reestruturação produtiva e das alterações na configuração do trabalho e da classe trabalhadora. Isso exigiu a quebra de paradigmas fundados na compreensão do trabalhador de chão de fábrica para a compreensão do trabalhador informal com contrato de trabalho flexível, considerado um desafio para os espaços das conferências.

As propostas resultantes das reflexões dos fóruns de discussão foram divididas nas seguintes temáticas: a) organização das ações de saúde do trabalhador; b) participação e controle social; c) informação; d) recursos humanos para a saúde do trabalhador; e) financiamento; f) legislação; g) desenvolvimento, meio ambiente, saúde e trabalho; h) política agrária e saúde do trabalhador; i) gerais (que reuniram propostas amplas, referentes a uma vasta e complexa gama de problemas de diversas ordens e não necessariamente relacionadas à Saúde do Trabalhador) (BRASIL, 1994). O modelo de sistema que possibilita efetivar uma política de saúde do(a) trabalhador(a) compreende um caráter interinstitucional e multidisciplinar das ações, tendo em vista a articulação de vários ministérios e profissionais das diversas áreas para ser capaz

7 Como disposto no relatório final, “a inclusão das ações de saúde do trabalhador como responsabilidade do SUS constituiu uma das maiores vitórias da classe trabalhadora no processo constituinte, agora referendada neste evento” (BRASIL, 1994, p. 3). 
de contemplar de fato a promoção, pesquisa, vigilância, assistência e reabilitação dos trabalhadores.

Tanto no momento da $1^{\text {a }}$ CNST quanto no da $2^{\text {a }}$ CNST, os Programas de Saúde do Trabalhador já vinham sendo realizados como ação de estruturação da área da saúde do(a) trabalhador(a) no âmbito da rede pública. Isso ocorreu inicialmente em São Paulo, no Rio de Janeiro, em Minas Gerais, no Rio Grande do Sul e na Bahia (LACAZ, 2005; BRASIL, 1994). Essa foi considerada área modelar para o setor da saúde, na medida em que congregava as ações de prevenção, concentradas na Vigilância, com aquelas de diagnóstico e cura presentes na Assistência à Saúde (BRASIL, 1994).

A constituição dos Centros de Referência em Saúde do trabalhador (Cerest) também foi objeto de atenção para a ampliação dos Programas de Saúde do Trabalhador (PST) - incluindo a preocupação de que fosse realizada com participação ${ }^{8}$ paritária das entidades sindicais e organizações populares na sua administração.

No que diz respeito às deliberações resultantes da $2^{\mathrm{a}} \mathrm{CNST}$, a construção de uma política de saúde do trabalhador pressupõe a garantia da transversalidade e da integralidade da ação do Estado, mediante: 1) a manutenção das garantias fundamentais dos cidadãos, assumindo as lutas pela sua regulamentação e seu efetivo cumprimento; 2) a segurança de atenção, promoção, tratamento e reabilitação em saúde de todos(as) os(as) trabalhadores(as); 3) a priorização das ações de promoção e prevenção em saúde do(a) trabalhador(a); 4) a garantia do caráter interinstitucional e multidisciplinar das ações de saúde do(a) trabalhador(a); e 5) o envolvimento de toda a rede pública de saúde (BRASIL, 1994). A participação e o controle social foram objeto de discussão e deliberação mediante propostas de ações nos Conselhos e nas Comissões Intersetoriais de Saúde do Trabalhador (Cist), tanto em nível nacional como estadual e municipal.

8 As instâncias de controle social democrático no SUS garantem a participação das organizações de trabalhadores urbanos e rurais por meio de sindicatos, federações, confederações e centrais sindicais, associações, comissões intersetoriais de saúde do trabalhador (Cist) dos estados e municípios, conselhos estaduais e municipais de saúde e conferências estaduais e municipais de saúde. 
Houve também, nesse momento, a sugestão de realização da conferência seguinte em um prazo máximo de 2 (dois) anos, incluindo a condução prévia de oficinas com a participação dos diversos setores envolvidos, para a elaboração de textos base sobre os assuntos a serem apreciados no momento da $3^{\text {a }}$ Conferência. Além disso, sugeriu-se que esses textos fossem distribuídos com antecedência, para a avaliação das Conferências Municipais e Estaduais.

\subsection{3. $3^{a}$ Conferência Nacional de Saúde do(a) Trabalhador(a) - 2005}

O prazo sugerido na $2^{\text {a }}$ CNST não foi cumprido e a $3^{\text {a }}$ Conferência Nacional de Saúde do(a) Trabalhador(a) foi realizada na sua etapa nacional, em Brasília, entre 24 e 27 de novembro de 2005, com o tema “Trabalhar, sim! Adoecer, não!”. Para subsidiar as discussões nas etapas municipais e estaduais, foi disponibilizada uma coletânea de textos e um documento-base.

Anteriormente a esse processo, a discussão da intersetorialidade foi retomada com a criação de Grupo de Trabalho Interministerial, por meio da Portaria $n^{0} 153$, de fevereiro de 2004, que resultou na elaboração da proposta da Política Nacional de Saúde e Segurança do Trabalhador e da Trabalhadora, colocada em consulta pública entre 5 de maio e 30 de novembro de 2005. Tal fato, posteriormente, deu origem à Política Nacional de Segurança e Saúde no Trabalho (PNSST), instituída pelo Decreto $\mathrm{n}^{0}$ 7.602, de 7 de novembro de 2011, que teve como objetivos “[...] a promoção da saúde e a melhoria da qualidade de vida do trabalhador e a prevenção de acidentes e de danos à saúde advindos, relacionados ao trabalho ou que ocorram no curso dele, por meio da eliminação ou redução dos riscos nos ambientes de trabalho” (BRASIL, 2011a).

Esse grupo de trabalho possibilitou a convocação oficial da $3^{\text {a }}$ CNST pelos Ministérios da Saúde, Previdência Social e Trabalho e Emprego. O contexto das mudanças no campo do trabalho ainda permanecia no ano 2000; na verdade, intensificaram-se as privatizações dos serviços públicos, o desemprego e o trabalho informal. O tema da $3^{\text {a }}$ CNST buscou resgatar a positividade do trabalho e desconstruir a 
relação trabalho-sofrimento, comum no imaginário social de tradição judaico-cristã (BRASIL, 2011a). No que tange à proteção social e ao controle democrático, o eixo temático III buscou responder à questão de como efetivar e ampliar o controle social em saúde dos(as) trabalhadores(as), o que pressupõe a participação popular na formulação das políticas públicas.

Na tentativa de identificar formas de efetivar e ampliar o controle social em saúde dos(as) trabalhadores(as), foram feitas considerações no sentido de delinear o panorama daquele momento, com a posterior definição de algumas deliberações. Nesse sentido, constatou-se que o trabalhador não dispunha de controle efetivo sobre o processo em que se inseria e sobre as consequências do ambiente de trabalho para a sua saúde - embora estivesse vivendo em um contexto de democratização e de abertura política que, progressivamente, já permitiam sua organização política, discussão coletiva e reivindicação de direitos. Também foi identificada a necessidade de qualificação dos trabalhadores e dos diversos setores do governo e da sociedade civil envolvidos ou comprometidos na sua representatividade nos espaços dos Conselhos e das Comissões Intersetoriais de Saúde do Trabalhador (Cist).

É interessante destacar que o controle efetivo sobre o processo de trabalho não é algo passível de ser concretizado no modo de produção capitalista, pressupondo a construção de outra sociabilidade, fundada na compreensão do humano genérico e do trabalho como elemento ontológico-social do ser social. Segundo Barroco (2005), mediações como a sociabilidade, a consciência, a universalidade e a liberdade (que possibilitam a reprodução do ser social) são construídas ao longo do processo de trabalho. Isso atribui ao trabalho seu caráter universal e sócio-histórico.

Apesar das contradições e limites postos pelo capitalismo, Duriguetto (2008), reforça que existem processos que potencializam a ação das classes subalternas na direção da formação da sua hegemonia (ou contra-hegemonia). Segundo a autora, isso indica a articulação da democracia com o socialismo, na medida em que "a democracia é entendida enquanto um processo que se constrói, desenvolve e se consolida a partir de espaços de luta, de formação de uma vontade coletiva, aberto 
ao avanço para a construção de um novo projeto societário que se contraponha ao capitalismo” (DURIGUETTO, 2008, p. 5).

Outro debate desencadeado nesse momento consistiu no controle democrático sobre o Serviço Especializado em Engenharia de Segurança e Medicina do Trabalho (SESMT) como a busca pela autonomia do trabalhador no controle da sua saúde. Os SESMT foram conhecidos, no seu histórico, como espaços da Medicina do Trabalho, que tinham como lócus de prática, tipicamente, os locais de trabalho com influência do pensamento mecanicista na medicina científica e na fisiologia. Em contraposição, há a concepção do campo da saúde do(a) trabalhador(a), que considera o trabalho como organizador da vida social, como o espaço de dominação e submissão do trabalhador pelo capital, mas, igualmente, de resistência, de constituição e do fazer histórico (MENDES; DIAS, 1991, p. 347).

As deliberações encaminhadas no sentido de efetivar e ampliar o controle social em saúde dos(as) trabalhadores(as) compreenderam a importância da implantação das Cist; do fortalecimento das Comissões Intersetoriais de Segurança e Saúde do Trabalhador (Cisst) no âmbito do SUS, com a participação de todos os agentes sociais envolvidos; da garantia da representação dos trabalhadores em todas as instituições públicas e privadas; da discussão sobre a função dos SESMT; dos mecanismos de transparência e responsabilização de todas as organizações empregadoras, no que tange à saúde e segurança dos trabalhadores; da realização de fóruns regionais e nacionais; da valorização e incentivo à participação do controle social na implantação e acompanhamento da Rede Nacional de Atenção Integral à Saúde do Trabalhador (Renast), criada em 2002 por meio da Portaria GM/MS nº 1.679 (BRASIL, 2002); da realização da CNST com um ano de antecedência à realização da Conferência Nacional de Saúde (CNS); do estabelecimento de canais regulares de acesso à população geral; da garantia de participação dos trabalhadores na elaboração de normas e políticas de segurança e saúde no trabalho e na fiscalização das condições de trabalho; e da promoção da intersetorialidade e transversalidade nas ações de políticas públicas em saúde do trabalhador, dentre outras. 
As demandas das Conferências versam sobre a dificuldade de uma atuação sem cooptação ou influências ideológicas opostas às da Reforma Sanitária e dos princípios levantados pela CF/88. Freire (2010), mesmo elaborando um estudo anterior à consolidação das Políticas de Saúde do Trabalhador, trouxe contribuições, à época, referentes aos desafios impostos aos movimentos sociais e ao controle social em saúde do trabalhador.

A análise dessa autora, em consonância com o que foi aqui apresentado, identificou a influência da reestruturação neoliberal, presente nas relações sociais de trabalho, como fator limitador da atuação dos movimentos sociais em razão do desemprego em massa e da contrarreforma do Estado. Então, apesar de os mecanismos de controle social democrático terem sido "retomados” no primeiro governo Lula (2003 a 2006), quando se verificaram novos estímulos, como a retomada das CNST após 11 anos, articuladas com as CNS nas três instâncias governamentais, estes sofrem os rebatimentos das alterações no campo do trabalho e do investimento restrito nas políticas sociais.

Reitera-se que esses elementos, conjugados a outros, afetam a estrutura da classe trabalhadora, suas formas de organização, sua capacidade de intervenção e seu acesso aos direitos sociais, refletindo nas condições de vida e trabalho e repercutindo no agravamento da questão social. O desafio imposto à sociedade civil organizada consiste em desenvolver processos políticos que objetivem organizar os interesses das classes subalternas e projetá-los em termos de ação hegemônica na direção da construção de um novo projeto societário (DURIGUETTO, 2008).

\subsection{4. $4^{a}$ Conferência Nacional de Saúde do(a) Trabalhador(a) - 2014}

Após nove anos de espera, a $4^{\text {a }}$ Conferência Nacional de Saúde do Trabalhador foi realizada em Brasília no período de 15 a 18 de dezembro de 2014, com o tema "Saúde do Trabalhador e da Trabalhadora: direito de todos e todas e dever do Estado.” Como etapa de preparação, a realização do Seminário Setorial com as Centrais Sindicais e Organizações Sociais, em março de 2014, objetivou sensibilizar o movimento sindical e social sobre a importância de implementar de fato a 
Política Nacional de Saúde do Trabalhador e da Trabalhadora (uma vez que esta já havia sido criada com a legislação pertinente). O momento do seminário favoreceu a articulação entre os representantes dos sindicatos e do Ministério da Saúde, o que resultou na elaboração de uma agenda de mobilização por setor econômico, considerada estratégica pelo CNS (BRASIL, 2014).

Nesse período já contávamos com a Política Nacional de Segurança e Saúde no Trabalho, instituída pelo Decreto $n^{0}$ 7.602, de 7 de novembro de 2011 (BRASIL, 2011b), responsável pela implementação e execução da política, além dos Ministérios do Trabalho e Emprego, da Saúde e da Previdência Social, sem prejuízo da participação de outros órgãos e instituições atuantes na área. As ações desenvolvidas como desdobramento dessa política estão inseridas no Plano Nacional de Segurança e Saúde no Trabalho (Plansat).

O fortalecimento da participação dos(as) trabalhadores(as), da comunidade e do controle social nas ações de saúde do(a) trabalhador(a) foram objeto de reflexão e de proposição na 4 a CNST. Os sujeitos envolvidos levantaram questões relacionadas à capacitação permanente dos conselhos; à importância de articulação com a universidade e ao controle interno e externo da política; à promoção de processos de educação permanente como o espaço dos fóruns, considerando a realidade local e regional; à promoção da gestão democrática e participativa nos serviços e no planejamento das ações de saúde, garantindo o envolvimento dos trabalhadores; à exigência da obrigatoriedade da criação das Comissões Intersetoriais de Saúde do Trabalhador (Cist) em todos os municípios brasileiros até novembro de 2015, por todos os Conselhos Municipais de Saúde (CMS), com apoio dos Conselhos e dos Cist nacional e estaduais, para fomentar a implantação e implementação da Vigilância em Saúde do Trabalhador (Visat), com controle social em todas as suas etapas; à inclusão, na agenda do Cerest, de um encontro mensal com entidades de classes (sindicatos) com representantes da Cist local, a fim de complementar e validar as ações de saúde do(a) trabalhador(a); e à criação de um fórum de discussão permanente sobre a saúde do(a) trabalhador, dentre outras. 
No caso da proteção social, ela será articulada com os princípios da integralidade e intersetorialidade como elementos necessários para a efetivação da PNSTT. Por ser um tema complexo, várias deliberações/ propostas foram levantadas e algumas, selecionadas, a saber: a aplicação das normas regulamentadoras para a redução dos riscos relacionados ao trabalho; a criação de um mecanismo equivalente à Comunicação de Acidente de Trabalho (CAT) para os servidores públicos; a ampliação das discussões sobre a desvinculação da medicina do trabalho do domínio dos empregadores; o desenvolvimento de um meio de comunicação nacional e de denúncias (aplicativo ou número de telefone); a continuidade e o aperfeiçoamento das políticas de redução da informalidade; a ampliação da cobertura previdenciária, bem como da inclusão e educação previdenciária; a transparência das informações do Instituto Nacional do Seguro Social (INSS); maior agilidade na perícia médica (que então podia levar até três meses de espera); a criação de Núcleos de Vigilância em Saúde do Trabalhador, com equipe multidisciplinar; a adoção da relação saúde/trabalho como premissa diagnóstica em toda a rede de atenção à saúde e em todos os níveis de complexidade, criando e implementando protocolos de identificação de agravos relacionados à saúde dos(as) trabalhadores(as); e a exigência do cumprimento da Portaria ${ }^{\circ} 2.728$, de 11 de novembro de 2009, segundo a qual todo município com mais de 500 mil habitantes deve ter o seu Cerest Municipal, dentre outras.

Considerando as informações aqui descritas sobre todas as Conferências realizadas, constata-se que as diversas demandas apresentadas (como a necessidade de constante capacitação dos atores sociais envolvidos e de ações que propiciem a transversalidade e a integralidade da saúde) são atemporais. Igualmente, compreende-se o quanto é necessária a articulação interministerial e interinstitucional com outras políticas, no sentido de fortalecer a proteção social, pois o tema tem sido recorrente nos relatórios finais. Por fim, o controle democrático, como estratégia de construção, avaliação e monitoramento da política pública pelos cidadãos articula-se com a atuação da sociedade civil 
organizada, no sentido de contribuir para que as demandas e interesses da coletividade se efetivem.

\section{A Política Nacional de Saúde do Trabalhador e da Trabalhadora (PNSTT)}

A instituição da PNSTT representa uma conquista da classe trabalhadora no sentido de definir os princípios, as diretrizes e as estratégias a serem observadas pelas três esferas de governo na gestão do SUS para o desenvolvimento da atenção integral à saúde do(a) trabalhador(a). Além disso, ela apoia concepções do movimento da Reforma Sanitária e sintetiza os marcos regulatórios legais, como a CF/88, a Lei Orgânica de Saúde e a Política Nacional de Segurança e Saúde no Trabalho, dentre outros.

Destaca-se, de início, a quem essa política é destinada, como disposto a seguir:

Art. $3^{\circ}$ Todos os trabalhadores, homens e mulheres, independentemente de sua localização, urbana ou rural, de sua forma de inserção no mercado de trabalho, formal ou informal, de seu vínculo empregatício, público ou privado, assalariado, autônomo, avulso, temporário, cooperativados, aprendiz, estagiário, doméstico, aposentado ou desempregado são sujeitos desta Política. (BRASIL, 2012, p. 1).

Apropriando-se das análises marxistas, e tendo em vista que o trabalho é inerente ao ser humano e funciona como meio para a sociabilidade, a PNSTT avança destinando essa política a todos, independentemente da situação de emprego, desemprego ou inserção no mercado de trabalho formal ou informal. Além disso, destaca a necessidade de prioridade para

Art. $7^{\circ}[. .$.$] pessoas e grupos em situação de maior vulne-$ rabilidade, como aqueles inseridos em atividades ou em relações informais e precárias de trabalho, em atividades 
de maior risco para a saúde, submetidos a formas nocivas de discriminação, ou ao trabalho infantil, na perspectiva de superar desigualdades sociais e de saúde e de buscar a equidade na atenção. (BRASIL, 2012, p. 1).

Os princípios e diretrizes observadas pela PNSTT - universalidade, integralidade, participação da comunidade, dos trabalhadores e do controle social, descentralização, hierarquização, equidade e precaução - apreendem os ditames elencados pela CF/88, art. 198, que faz com que a PNSTT esteja em concordância com os princípios do SUS. A criação da Rede Nacional de Atenção Integral à Saúde do Trabalhador (Renast), em 2002, representou um avanço significativo na organização institucional das ações e na disseminação de informações referentes ao campo saúde do(a) trabalhador(a). Em 2005 e em 2009, foram publicadas novas portarias, visando fortalecer e adequar suas ações, que integram o sistema por meio dos Cerest de cada região, e também estabelece a articulação com o Ministério da Saúde, com as Secretarias de Saúde, com o Distrito Federal e com os municípios.

Além de buscar apoio nas deliberações expostas no relatório final da 4 a CNST, os estudos de Minayo-Gomez (2013) e de Lacaz e Florio (2009) forneceram contribuições para a análise da PNSTT, especialmente na tentativa de apontar seus avanços e desafios. A pesquisa também possibilitou identificar algumas pistas sobre a situação do trabalho e das legislações trabalhistas e previdenciárias no país. Dentre os avanços observados com a implementação da PNSTT, incluem-se:

1) Incorporação de propostas que as entidades representativas da sociedade civil, profissionais e pesquisadores de saúde vinham almejando desde a $1^{\text {a }}$ CNST, como o conceito ampliado de saúde, a saúde como direito do cidadão e dever do Estado, a previsão da criação das comissões, dentre outras.

2) Definição dos princípios, diretrizes e estratégias a serem observadas pelas três esferas de governo e de gestão do SUS para o desenvolvimento da atenção integral à saúde. 
3) Integração da PNSTT e da PNSST ao conjunto de políticas de saúde do SUS.

4) Inclusão de todos os(as) trabalhadores(as), a partir da compreensão de que o trabalho é inerente ao ser humano e também meio para a sociabilidade, destinando essa política a todos, independentemente da situação de emprego/desemprego ou inserção no mercado de trabalho informal.

Para a identificação e listagem dos desafios postos na materialização da PNSTT, cabe relacionar os limites dessa política diante de determinantes macroestruturais da economia e da sociedade. Assim sendo, têm-se:

1) O contexto econômico social de destruição de direitos sociais duramente conquistados pela classe trabalhadora, a exemplo das legislações trabalhistas e previdenciárias.

2) A precarização dos vínculos e dos contratos de trabalho, que ocorre pela via da terceirização e das insuficientes condições de trabalho representadas pelo trabalho voluntário, subcontratos, terceirizações, empreendedorismo etc.

3) O enfraquecimento e dificuldade na organização da classe trabalhadora e na atuação dos movimentos sociais em ações pela prevenção dos agravos e pela manutenção dos direitos conquistados.

4) O desafio da implantação e de manutenção de Cerests nos municípios e estados brasileiros, além da dificuldade em manter recursos materiais e quadro de pessoal suficiente, capacitado e dotado de carreira compatível com as funções essenciais do Estado.

5) A necessidade da garantia da Vigilância em Saúde do Trabalhador (Visat) como objetivo prioritário, devido aos recursos escassos. 
Raichelis (2006) reforça que é fundamental estimular a organização de fóruns mais amplos de representação e participação social e política, não institucionalizados, menos formalizados e burocratizados, que se tornarão, em consequência, mais permeáveis à participação popular como instrumentos dinamizadores no caminho da representatividade e legitimidade social.

\section{Considerações finais}

Observa-se que a realidade está em constante transformação e há a necessidade de ações coletivas para enfrentar os desafios postos no cotidiano. É indispensável o empenho de todos(as) no estabelecimento de articulações que visem à constituição de uma rede de atenção integral à saúde dos(as) trabalhadores(as). Os protagonistas são aqueles que vendem sua força de trabalho no mercado cotidianamente, sofrendo os rebatimentos da degradação das relações trabalhistas e previdenciárias. Muitas vezes, não conseguem participar dos espaços de reflexão sobre as decisões realizadas por governantes e contam com a atuação dos sindicatos, centrais sindicais e movimentos sociais para representá-los.

Constata-se que é urgente fortalecer os espaços de participação social e dar condições para o envolvimento da população, mediante a capacitação e o comprometimento, estimulando a organização de fóruns mais amplos de representação e participação social e política, não institucionalizados, menos formalizados e burocratizados, na tentativa de aproximação com os trabalhadores desempregados ou inseridos no mercado de trabalho informal, além de exigir a periodicidade da realização das conferências temáticas - dentre elas, a de Saúde do(a) Trabalhador(a).

Mesmo diante dos limites impostos, nota-se que a temática avançou em decorrência das CNST, como espaço de viabilização das lutas sociais e confronto de projetos societários. Em consequência, foram construídas a Política Nacional de Saúde e Segurança no Trabalho (PNSST), em 2011, e a Política Nacional de Saúde do Trabalhador e da Trabalhadora (PNSTT), em 2012. Apesar de todos os avanços no sentido da democratização do país, a perspectiva de universalidade da 
proteção social mostra-se em confronto com as regras do capital, que exploram e degradam a força de trabalho.

Nitidamente, a política social é um espaço de disputa e de acirramento de projetos de classe, antagônicos e opostos por natureza. É urgente o fortalecimento de instâncias representativas, em todos os níveis, como a clareza e aproximação dos Centros de Referência em Saúde do Trabalhador (Cerest) junto à população, o acompanhamento da Rede Nacional de Saúde do Trabalhador (Renast) e a socialização das informações concernentes à prevenção e promoção de saúde. Para a consolidação e o reconhecimento do campo da saúde do(a) trabalhador(a) na realidade brasileira, é fundamental o fortalecimento da proteção social e do controle democrático em todas as esferas (ou instâncias) de participação e representação política e social.

\section{Referências}

ALVES, Giovanni. O novo (e precário) mundo do trabalho: reestruturação produtiva e crise do sindicalismo. São Paulo: Boitempo, 2005.

ANTUNES, Ricardo. Adeus ao Trabalho? Ensaio sobre as metamorfoses e a centralidade do mundo do trabalho. São Paulo: Cortez, 2015. ANTUNES, Ricardo; ALVES, Giovanni. As mutações no mundo do trabalho na era da mundialização do capital. Educação e Sociedade, Campinas, v. 25, n. 87, p. 335-351, maio/ago. 2004.

BARBOSA, Rosangela Nair de Carvalho. A economia solidária como política pública: uma tendência de geração de renda e ressignificação do trabalho no Brasil. São Paulo: Cortez, 2007.

BARROCO, Maria Lucia Silva. Ética e Serviço Social: fundamentos ontológicos. São Paulo: Cortez, 2005.

BRASIL. Ministério da Saúde. Conselho Nacional de Saúde. $1^{a}$ Conferência Nacional de Saúde dos Trabalhadores. Brasília, 1986. Disponível em: http://bvsms.saude.gov.br/bvs/publicacoes/1a_conf_nac_saude_ trabalhador.pdf. Acesso em: 9 jul. 2019. 
BRASIL. Ministério da Saúde. Conselho Nacional de Saúde. $4^{a}$ Conferência Nacional de Saúde do Trabalhador e da Trabalhadora: relatório final. Brasília, 2015. 234 p. Disponível em: http://renastonline. ensp.fiocruz.br/sites/default/files/arquivos/recursos/Relatorio_4cnstt_ final_31072015.pdf. Acesso em: 16 maio 2020.

BRASIL. Ministério da Saúde. Conselho Nacional de Saúde. Relatório Final da $2^{\text {a }}$ Conferência Nacional de Saúde do Trabalhador. Brasília, 1994. Disponível em: http://bvsms.saude.gov.br/bvs/publicacoes/0207cnst_ relat_final.pdf. Acesso em: 16 maio 2020.

BRASIL. Ministério da Saúde. Conselho Nacional de Saúde. Relatório Final da $8^{a}$ Conferência Nacional de Saúde. Brasília: Ministério da Saúde, 1987.

BRASIL. Ministério da Saúde. Portaria no 1.679/GM, de 19 de setembro de 2002. Dispõe sobre a estruturação da rede nacional de atenção integral à saúde do trabalhador no SUS e dá outras providências. Diário Oficial da União, Brasília, Seção 1, p. 53. 20 set. 2002.

BRASIL. Ministério da Saúde. Portaria nº 1.823/GM, de 23 de agosto de 2012. Institui a Política Nacional de Saúde do Trabalhador e da Trabalhadora. Diário Oficial da União, Brasília, Seção 1, p. 46, 24 ago. 2012. BRASIL. Ministério da Saúde. Secretaria de Vigilância em Saúde. Departamento de Vigilância em Saúde Ambiental e Saúde do Trabalhador. Trabalhar sim! Adoecer, não!: o processo de construção e realização da $3^{\text {a }}$ Conferência Nacional de Saúde do Trabalhador. Relatório ampliado da $3^{\text {a }}$ CNST. Brasília: Ministério da Saúde, 2011a. 224 p. (Série D. Reuniões e Conferências).

BRASIL. Presidência da República. Decreto nº 7.602, de 7 de novembro de 2011. Dispõe sobre a Política Nacional de Segurança e Saúde no Trabalho - PNSST. Diário Oficial da União, Brasília, 8 nov. 2011b. Disponível em: https://www.planalto.gov.br/ccivil_03/_ato2011-2014/2011/ decreto/d7602.htm. Acesso em: 9 jul. 2019. 
BRASIL. Presidência da República. Lei nº 8.080, de 19 de setembro de 1990. Dispõe sobre as condições para a promoção, proteção e recuperação da saúde, a organização e o funcionamento dos serviços correspondentes e dá outras providências. Diário Oficial da União, Brasília, Seção 1, p. 18055, 20 set. 1990a.

BRASIL. Presidência da República. Lei no 8.142, de 28 de dezembro de 1990. Dispõe sobre a participação da comunidade na gestão do Sistema Único de Saúde (SUS) e sobre as transferências intergovernamentais de recursos financeiros na área da saúde e dá outras providências. Diário Oficial da União, Brasília, Seção 1, p. 25694, 31 dez. 1990b.

BRAVO, Maria Inês Souza; MENEZES, Juliana Souza Bravo de (org.). Saúde na atualidade: por um sistema único de saúde estatal, universal, gratuito e de qualidade. Rio de Janeiro: UERJ, Rede Sirius, 2011. COUTINHO, Carlos Nelson. Gramsci: um estudo sobre seu pensamento político. Rio de Janeiro: Civilização Brasileira, 1999.

DURIGUETTO, Maria Lúcia. Sociedade Civil e Democracia: um debate necessário. Libertas, Juiz de Fora, v. 8, n. 2, p. 83-94, jul./dez. 2008. Disponível em: https://libertas.ufjf.emnuvens.com.br/libertas/article/ view/1790/1265. Acesso em: 23 jan. 2017.

FREIRE, Lúcia M. de B. Movimentos sociais e controle social em saúde do trabalhador: inflexões, dissensos e assessoria do Serviço Social. Serviço Social e Sociedade, São Paulo, n. 102, abr./jun., 2010. Disponível em: http://www.scielo.br/scielo.php?script=sci_arttext\&pi d=S0101-66282010000200006. Acesso em: 9 jul. 2019.

LACAZ, Francisco Antonio de Castro. Saúde do trabalhador: vinte anos de história e trajetória. In: CONSELHO NACIONAL DE SAÚDE (CNS). $3^{a}$ Conferência Nacional em Saúde do Trabalhador: "Trabalhar, sim! Adoecer, não!”. Coletânea de textos. Brasília: Ministério da Saúde, 2005. P. 72-78. Disponível em: http://bvsms.saude.gov.br/bvs/ trabalhador/pdf/coletanea_textos_econf.pdf. Acesso em: 9 jul. 2019. 
LACAZ, Francisco Antonio de Castro; FLORIO, Solange Maria Ribeiro. Controle social, mundo do trabalho e as Conferências Nacionais de Saúde da virada do século XX. Revista Ciência e Saúde Coletiva, Rio de Janeiro, v. 14, n. 6, p. 2123-2134, 2009. Disponível em: http://dx.doi. org/10.1590/S1413-81232009000600019. Acesso em: 9 jul. 2019.

LAURELL, Asa Cristina. A saúde-doença como processo social. Tradução: E. D. Nunes. Revista Latinoamericana de Salud, México, n. 2, p. 7-25, 1982. Disponível em: https://unasus2.moodle.ufsc.br/pluginfile. php/6126/mod_resource/content/1/Conteudo_on-line_2403/un01/pdf/ Artigo_A_SAUDE-DOENCA.pdf. Acesso em: 9 jul. 2019.

MARX, Karl; ENGELS, Friedrich. A Ideologia Alemã: crítica da mais recente filosofia alemã em seus representantes Feuerbach, B. Bauer e Stirner, e do socialismo alemão em seus diferentes profetas (18451846). São Paulo: Boitempo, 2007. Disponível em: http://abdet.com. br/site/wp-content/uploads/2014/12/A-Ideologia-Alem\%C3\%A3.pdf. Acesso em: 9 jul. 2019.

MENDES, René; DIAS, Elizabeth Costa. Da medicina do trabalho à saúde do trabalhador. Revista de Saúde Pública, São Paulo, v. 25, n. 5, p. 341-9, 1991.

MINAYO-GOMEZ, Carlos. Avanços e entraves na implementação da Política Nacional de Saúde do Trabalhador. Revista Brasileira de Saúde Ocupacional, São Paulo, v. 38, n. 127, p. 21-25, 2013. Disponível em: http://dx.doi.org/10.1590/S0303-76572013000100004. Acesso em: 9 jul. 2019.

MORAES, Reginaldo C. Neoliberalismo: de onde vem, para onde vai? São Paulo: Senac, 2001. Disponível em: https://reginaldomoraes.files. wordpress.com/2012/01/livro_neoliberalismo.pdf. Acesso em: 9 jul. 2019. OLIVAR, Mônica Simone Pereira. O campo político da saúde do trabalhador e o Serviço Social. Serviço Social e Sociedade, São Paulo, n. 102, 2010. 
PEREIRA-PEREIRA, Potyara Amazoneida. Política Social no capitalismo em crise. Desafios atuais e guerra de classe. Leste Vermelho: Revista de estudos críticos asiáticos, [s. l.], v. 2, n. 1, abr. 2016.

PEREIRA-PEREIRA, Potyara Amazoneida. Política Social: temas \& questões. São Paulo: Cortez, 2008.

RAICHELIS, Raquel. Democratizar a gestão das políticas sociais: um desafio a ser enfrentado pela sociedade civil. In: MOTA, Ana E. et al. (org.). Serviço Social e Saúde: formação e trabalho profissional. São Paulo: Cortez, 2006. Disponível em: http://www.fnepas.org.br/pdf/ servico_social_saude/texto1-4.pdf. Acesso em: 16 mai. 2020.

ROCHA, Patrícia Rodrigues da; DAVID, Helena Maria Scherlowski Leal. Determinação ou Determinantes? Uma discussão com base na Teoria da Produção Social da Saúde. Revista da Escola de Enfermagem da USP, São Paulo, v. 49, n. 1, p. 129-135, 2015.

SOUZA, Carlos Henrique Leite de. A que vieram as conferências nacionais? Uma análise dos objetivos dos processos realizados entre 2003 e 2010. In: AVRITZER, Leonardo; SOUZA, Clóvis Henrique Leite de (org.). Conferências Nacionais: atores, dinâmicas participativas e efetividade. Rio de Janeiro: Ipea, 2013. Disponível em: http://www.ipea. gov.br/portal/images/stories/PDFs/livros/livros/livro_conferencias_ nacionais.pdf. Acesso em: 9 jul. 2019. 


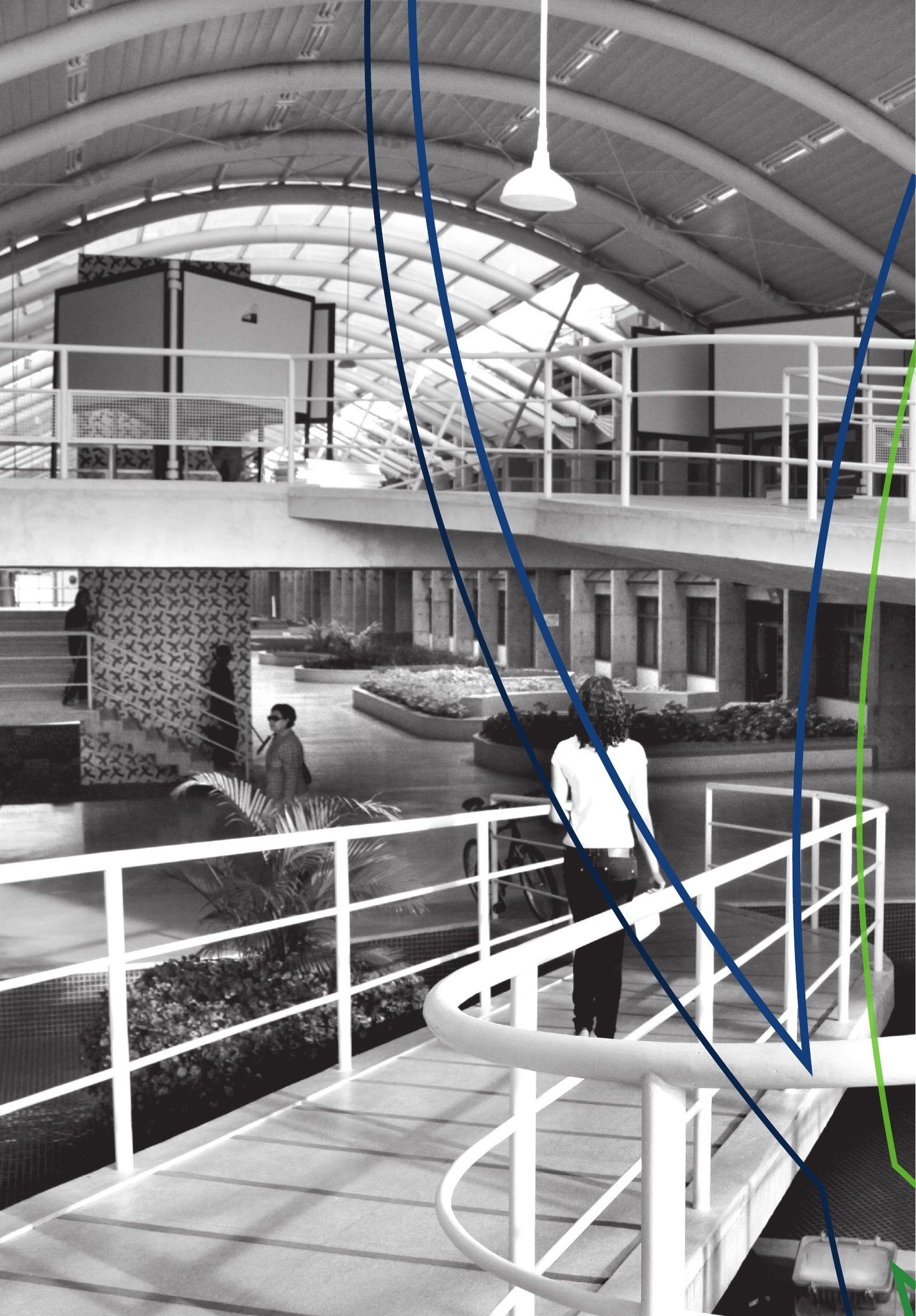


Capítulo 5

A Política Nacional de Educação Permanente do Sistema Único de Assistência Social

Renata Maria da Conceição Freitas

Universidade de Brasília (UnB) renatamariabsb@gmail.com

\section{Introdução}

O presente texto analisa a Política Nacional de Educação Permanente para trabalhadores do Sistema Único de Assistência Social (Suas), com o objetivo de identificar seus limites, possibilidades e perspectivas recentes. Destaca, no decorrer das análises, um contexto marcado 
pela precarização do trabalho, com graves consequências para os trabalhadores do Suas.

A Política Nacional de Educação Permanente para trabalhadores do Suas - PNEP/Suas (BRASIL, 2013) constitui-se como um desafio a todos os trabalhadores da assistência social, em suas diversas funções, desde aqueles responsáveis pela prestação dos serviços socioassistenciais até os que compõem a esfera da gestão e os membros dos conselhos de assistência social.

A proposta de implementação de uma política de capacitação por meio de percursos formativos demonstra a dinamicidade do próprio Suas e a heterogeneidade da composição do conjunto de seus trabalhadores. A PNEP/Suas se coloca como paradigma para a formatação e oferta das ações de formação e qualificação no âmbito do Suas, definindo percursos formativos que compreendam desde a sua gestão e o provimento de serviços e benefícios socioassistenciais até o controle social exercido no âmbito dos conselhos.

Do ponto de vista político, a elaboração de uma política de capacitação se deu no seio das Conferências Nacionais de Assistência Social como uma demanda fundamental para os trabalhadores dessa área, considerando que a assistência social se constituiu em uma rede integrada que oferta serviços de proteção socioassistenciais e que deve garantir a qualidade desses serviços, para que se efetive o direito à proteção social.

As Conferências Nacionais se apresentam como um espaço de participação no qual são definidas as pautas consideradas mais importantes para os trabalhadores da assistência social. Nessas ocasiões, identificam-se avanços e desafios para a categoria e para a prestação dos serviços, além das condições estruturais que interferem na operacionalização da política, entre outras questões cruciais para o desenvolvimento da política social no país.

Entre 1995 e 2013, aconteceram nove Conferências Nacionais, em que recorrentemente se pautou a necessidade de formação e capacitação dos trabalhadores e gestores da rede, demonstrando que existiam disputas de projetos políticos relacionados à questão da educação e trabalho no âmbito da assistência social. 
A importância de ações de formação e capacitação em assistência social se dá em decorrência da institucionalização da área, o que conduz à necessidade de fortalecimento das ações profissionais específicas nos processos de trabalho voltados à gestão ou à prestação de serviços e benefícios. Esses processos, por outro lado, demandam conhecimentos que não são atributos exclusivos de assistentes sociais, sendo reconhecida a importância e participação de outras áreas nesse contexto.

Também fica evidente que não há um nivelamento em relação à escolaridade dos trabalhadores da área da assistência social, conforme demonstrado pelo Censo Suas 2014, no qual a composição dos trabalhadores estava distribuída em nível fundamental (15\%), nível médio (49\%) e superior (36\%), o que mostra que há espaço para um aprofundamento teórico e analítico sobre as questões que tocam o cotidiano dos trabalhadores do Suas.

O percurso de análise seguido neste estudo tem como base teórico-metodológica o método materialista histórico-dialético, que se propõe a ser um parâmetro crítico e científico não apenas voltado a analisar superficialmente a realidade, separando-a em partes, mas decompondo sua aparência, por aproximações sucessivas. Essas aproximações partem da aparência para a essência dos fenômenos sociais, com a intenção de alcançar os nexos causais mais concretos e compreender a totalidade nas suas múltiplas determinações e contradições (TANEZINI, 2010).

A partir dessa base teórica de parâmetro crítico de análise da realidade social, definiu-se como objeto de exame a Política Nacional de Educação Permanente para Trabalhadores do Sistema Único de Assistência Social - PNEP/Suas (2013), considerando seus limites, possibilidades e alcances.

O processo de pesquisa considerou as seguintes perguntas: 1) como a PNEP/Suas pode contribuir para a melhoria dos serviços prestados e para a qualificação dos trabalhadores? 2) Como está sendo implementada a PNEP/Suas no contexto de precarização do trabalho? 3) Nas atuais condições de trabalho no capitalismo, é possível garantir educação permanente para a classe trabalhadora, como é o caso dos trabalhadores do Suas? 
A partir dessas questões, analisou-se a PNEP/Suas à luz da precarização do trabalho no interior do modo de produção capitalista. Diante da natureza complexa da temática, foi delimitado um recorte temporal para a pesquisa, demarcando o período de constituição da Política Nacional de Assistência Social (PNAS), em 2004, até a divulgação do Censo do Sistema Único de Assistência Social, realizado em 2015 (BRASIL, 2016).

A pesquisa se dividiu nas seguintes operações metodológicas: 1) revisão de literatura; 2) pesquisa exploratória com perguntas a serem respondidas; 3) definição dos indicadores para análise da política; e 4) definição da descrição e interpretação da política nacional de educação permanente.

Nessa divisão de operações metodológicas, definiram-se, para a análise da PNEP/Suas, indicadores referentes aos trabalhadores, a saber: 1) o vínculo formal, já que objetivamos conhecer aproximadamente as condições de trabalho no âmbito do Suas; 2) o nível de formação, para compreender como está disposta a formação acadêmica, considerando o quadro de trabalhadores do Suas; 3) as particularidades regionais, pois esse indicador possibilita mapear as áreas que possuem mais fragilidades em relação ao quadro de trabalhadores que não tiveram acesso à educação permanente ofertada pela política.

Com base nisso, foi necessário problematizar a política para compreender os seus limites e possibilidades, tendo em vista a atual configuração do mundo do trabalho no capitalismo. Desse modo, fizeram-se oportunas visitas ao antigo Ministério do Desenvolvimento Social e Combate à Fome (MDS), no período de abril a julho de 2016. A intenção dessas visitas institucionais foi a de conhecer a realidade política institucional sobre a qual a PNEP/Suas foi construída, além de compreender as concepções e posicionamentos dos gestores sobre tal construção.

Foram contatados dois gestores que integravam, à época, o quadro do MDS, lotados na Secretaria de Avaliação e Gestão da Informação (Sagi), unidade responsável pelas ações de gestão da informação, monitoramento, avaliação e capacitação de agentes sociais, sendo importante destacar a necessidade de manter o anonimato das identidades 
para garantir os cuidados éticos necessários em relação à pesquisa. Foi escolhida como metodologia de obtenção de dados o uso do diário de campo, tendo sido realizadas perguntas gerais e abertas aos referidos gestores durante as visitas.

\section{Contextualização sócio-histórica da Política Nacional de Educação Permanente para Trabalhadores do Sistema Único de Assistência Social}

A assistência social, antes de constituir-se como a base da seguridade social, ${ }^{1}$ teve início como parte de ações e práticas de caridade, de cunho assistencialista. ${ }^{2}$ No decorrer das lutas pela redemocratização do país, entre o período da abertura política pós-ditadura de 1964 até a promulgação da Constituição Federal de 1988 (CF/88), a assistência social passou a compor uma política pública mais ampla, que tem o propósito de garantir proteção social ${ }^{3}$ a quem dela necessitar, sendo afirmada como um dever do Estado e direito de cidadania.

1 Na década de 1970, surgiu a proposta do Estado de bem-estar social (welfare state), que, guardadas as devidas particularidades regionais e econômicas, tinha por objetivo estabelecer um sistema de seguridade social que garantia uma espécie de salário indireto ao trabalhador, além de ter sido gestado juntamente com políticas sociais que se baseavam na manutenção de serviços públicos gratuitos, consoante a proposta fordista de liberar o salário do trabalhador para o consumo, com foco no desenvolvimento de uma economia de pleno emprego e de consumo em massa (BEHRING; BOSCHETTI, 2010).

2 O welfare state não altera o cerne da questão social, apenas tenta regular alguns direitos. Pelos seus ideais, todo indivíduo possui direitos do seu nascimento até sua morte, que fariam parte de um conjunto organizado de serviços, regulando a sociedade civil. Tais direitos seriam a educação pública, a assistência médica pública, o auxílio desemprego, a assistência aos inválidos e as aposentadorias, constituindo um investimento na área social a fim de amenizar os conflitos de classes e servindo como um segundo salário (salário indireto) (BEHRING; BOSCHETTI, 2010).

3 Refere-se à intervenção estatal por meio da regulação econômica, no sentido de garantir políticas sociais, contribuindo com a ampliação das atribuições do Estado e passando a constituir um sistema de proteção do cidadão com o objetivo de dar respostas às expressões da “questão social”. 
A proteção social é um conceito que abarca as formas institucionais que o Estado promove para proteger o conjunto dos cidadãos - um sistema de proteção contra riscos sociais que comprometem as condições de vida. A proteção social parte do Estado na perspectiva da política social, sob condições históricas particulares, conforme o desenvolvimento do capitalismo em cada situação e suas contradições (BEHRING; BOSCHETTI, 2010).

Segundo Ivo et al. (2013),

[o] debate contemporâneo sobre proteção social é dominado pela gramática do emprego e do salário. O pressuposto institucional das discussões sobre formalidade versus informalidade, emprego versus desemprego, políticas salariais, políticas previdenciárias, entre outros temas é a existência de contratos de emprego como forma padrão de contratação de mão-de-obra. O contrato de emprego é a porta de entrada para todos os benefícios sociais, desde a criação de direitos por via legislativa passando pela previdência social. (IVO et al., 2013, p. 168-169).

Portanto, países com níveis distintos de justiça social respondem diferentemente às vulnerabilidades sociais de seus cidadãos. No Brasil, a proteção social se estrutura basicamente em três grandes eixos: saúde, assistência social e previdência social (IVO et al., 2013). Assim, torna-se imprescindível analisar a institucionalização da assistência social para compreender que, como parte de um processo histórico, ela ganha corpo de direito e busca se desvincular da perspectiva assistencialista.

Nesse sentido, a Política Nacional de Educação Permanente do Suas - PNEP/Suas (2013) é uma política voltada para a qualificação dos trabalhadores que compõem os recursos humanos da assistência social, dispondo sobre os princípios e diretrizes para aprimorar os serviços prestados por esses trabalhadores. Como um dever do Estado desde a CF/88, a assistência social constituiu-se em uma rede integrada que 
oferta serviços de proteção socioassistenciais e que deve garantir a qualidade desses serviços, para que se efetive o direito à proteção social. ${ }^{4}$

A PNEP/Suas ganhou notoriedade e forma no decorrer das discussões que aconteceram durante as Conferências Nacionais de Assistência Social, de 1995 a 2011 (BRASIL, 2013).

Em 2004, a Política Nacional de Assistência Social (PNAS) estabeleceu os procedimentos, princípios e diretrizes que deveriam colocar em execução a Lei Orgânica da Assistência Social (Loas), de 1993, além da operacionalização proposta pelas Normas Operacionais Básicas (NOB/Suas/2005, NOB/Suas/2012 e NOB-RH/Suas/2006), que contribuíram para modelar a estrutura da assistência social.

A I Conferência, realizada em 1995, trazia como tema: "A Assistência Social como um direito do cidadão e dever do Estado”, e teve como deliberações as propostas de que o Conselho Nacional de Assistência Social (CNAS) e a Secretaria Nacional de Assistência Social (SAS) promovessem programas de capacitação, além de construírem uma política de qualificação sistemática e continuada de recursos humanos (BRASIL, 2013). O que os trabalhadores da assistência reivindicavam eram as demandas que surgiam no posto de trabalho sobre a necessidade de capacitações, as quais foram propostas em debates nessa conferência.

A II Conferência Nacional de Assistência Social, de 1997, trouxe como tema: "O sistema descentralizado e participativo da Assistência Social: construindo a inclusão e a universalidade de direitos”, em que já se falava em implantação do processo de capacitação permanente (BRASIL, 2013). Para assegurar direitos, a assistência social precisava

4 O novo arcabouço legal, incluindo a Lei Orgânica da Assistência Social (Loas), de 1993, coloca a questão da seguridade e proteção social a partir de um viés de direitos sociais, com base na universalização e na responsabilidade do Estado, em um processo que tem por objetivo culminar em uma política pública e de direitos. Representa um grande progresso, na medida em que permite que a assistência social passe de um caráter essencialmente assistencialista e clientelista para a institucionalização de uma política social de Estado, que visa defender e atender as demandas dos setores mais carentes da sociedade (YAZBEK, 1995, p. 10). 
garantir que os trabalhadores tivessem acesso a uma capacitação permanente, que abarcasse o novo sentido democrático trazido por tal política.

Na III Conferência, em 2001, com o tema: "Política de Assistência Social: uma trajetória de avanços e desafios”, a questão da qualificação dos profissionais da assistência social estava latente, tendo-se proposto como deliberação elaborar e implementar uma política nacional de capacitação continuada e descentralizada, com financiamento nas três esferas de governo (BRASIL, 2013). A necessidade apresentada nas conferências aumenta a cada nível, a fim de que seus trabalhadores sejam valorizados e sua qualificação seja garantida de forma contínua e precisa.

Foi discutida a corresponsabilidade entre os três entes federados no financiamento do quadro de recursos humanos, defendendo-se, inclusive, a contratação no setor público; porém, foi na IV Conferência Nacional de Assistência Social, em 2003, que se constituíram fóruns de formação para discussão de uma política específica para os trabalhadores da assistência social (BRASIL, 2013). Essa edição da Conferência teve como tema a “Assistência Social como política de inclusão: uma nova agenda para a cidadania - Loas 10 anos”, que definiu as diretrizes da criação do Suas.

Por sua vez, em 2005, a V Conferência Nacional de Assistência Social adotou a temática: "Suas - Plano 10: estratégias e metas para a implementação da política nacional de Assistência Social”, na qual se deliberou sobre a implantação de uma política de capacitação continuada e orientada por princípios éticos, políticos e profissionais, visando à qualidade do atendimento prestado na assistência social (BRASIL, 2013).

Para além do apontamento da necessidade da criação de uma política nacional de capacitação, em 2006 ocorreu a organização da demanda de uma NOB específica para tratar os recursos humanos dentro da assistência social. Assim, a VI Conferência, realizada em 2007, abordou o tema: "Compromissos e responsabilidades para assegurar proteção social pelo Sistema Único de Assistência Social”, e teve como base a NOB-RH/ Suas/2006 (CNAS, 2006), que trazia em seus princípios a estruturação do trabalho e a qualificação e valorização dos trabalhadores no Suas.

Nessa Conferência foi proposta, como diretriz para a mencionada política nacional de capacitação, a observância de princípios éticos, 
políticos e profissionais para a qualidade dos serviços socioassistenciais (BRASIL, 2013). A VII Conferência Nacional (2009), com o tema: "Participação e controle social no Suas”, apresentou a necessidade da criação de espaços de diálogo entre os trabalhadores, continuando com o apontamento da necessidade de qualificação para esse segmento.

A partir dessa Conferência, discute-se a capacitação "continuada e permanente" que constava como proposta, mediante o cofinanciamento dos entes federados, respeitando diferenças sociais e regionais e a interface com outras políticas públicas (BRASIL, 2013). Com a aprovação da Resolução CNAS nº 109, de 11 de novembro de 2009, que delibera sobre a Tipificação Nacional de Serviços Socioasssistenciais, ressalta-se a urgência de uma política específica para a qualificação dos trabalhadores.

A VIII Conferência Nacional de Assistência Social, ocorrida em 2011, sob o tema: “Avançando na consolidação do Suas, com a valorização dos trabalhadores e a qualificação da gestão, dos serviços, programas, projetos e benefícios”, contava com avanços propostos pelas conferências anteriores, como também pela Loas, que foi alterada pela Lei $n^{0}$ 12.435, de 6 de julho de 2011, visando garantir a utilização dos recursos do cofinanciamento federal voltados para ações continuadas no âmbito da assistência social, como o pagamento de profissionais efetivos que integram as equipes de referência ${ }^{5}$ (BRASIL, 2013).

Considerando as deliberações da oitava conferência, temos dois aspectos que se destacam em relação à construção da PNEP/Suas, que são: a implantação da Gestão do Trabalho, a partir da NOB-RH/Suas/2006 nos entes federados, visando à qualificação das práticas de trabalho do Suas e tendo em vista a análise do número de trabalhadores necessários para a demanda de serviços prestados; e a construção de uma Política de Capacitação Continuada, de acordo com a NOB-RH/Suas/2006, com recursos dos entes federados, voltada para os trabalhadores da

\footnotetext{
5 "Equipes de referência são aquelas constituídas por servidores efetivos responsáveis pela organização e oferta de serviços, programas, projetos e benefícios de proteção social básica e especial, levando-se em consideração o número de famílias e indivíduos referenciados, o tipo de atendimento e as aquisições que devem ser garantidas aos usuários.” (BRASIL, 2011, p. 25).
} 
assistência social, orientando-se pelo princípio da profissionalização, ética e atendimento aos usuários como sujeitos de direitos (BRASIL, 2013). Dessa forma, buscou-se garantir e incentivar cursos para a profissionalização dos trabalhadores do Suas.

Concomitantemente ao processo de elaboração da Política Nacional de Educação Permanente, em 2012, ocorria a implementação do Programa Nacional de Capacitação do Suas (CapacitaSuas), por meio da Resolução CNAS nº 8/2012 (CNAS, 2012). Esse programa tinha como objetivo garantir a oferta de formação permanente, capacitar técnicos e gestores e implementar planos estratégicos dos entes federados (BRASIL, 2013), e foi uma primeira experiência de pacto de implantação de ações de formação continuada nas três esferas de governo.

\subsection{A Gestão do Trabalho e sua relação com a PNEP/Suas}

Para a assistência social, a educação permanente como processo formativo é um projeto reivindicado para atender os profissionais que atuam no âmbito do Suas, considerando que a rede de assistência social possuía, no ano de 2014, cerca de 23.741 equipamentos distribuídos em 8.088 Centros de Referência da Assistência Social (Cras) ${ }^{6}$ de atuação nacional, 2.372 Centros de Referência Especializados da Assistência Social (Creas) 7 , 215 Centros de Referência Especializados para População em Situação de Rua (Centros POP), 7.882 Centros de Convivência

6 O Cras “é uma unidade pública estatal descentralizada da política de assistência social sendo responsável pela organização e oferta dos serviços socioassistenciais da Proteção Social Básica do Sistema Único de Assistência Social (SUAS) nas áreas de vulnerabilidade e risco social dos municípios e DF” (ALAGOAS, [2017]).

7 O Creas é uma unidade pública que oferta serviço especializado e continuado a famílias e indivíduos (crianças, adolescentes, jovens, adultos, idosos, mulheres), em situação de ameaça ou violação de direitos, tais como: violência física, psicológica, sexual, tráfico de pessoas, cumprimento de medidas socioeducativas em meio aberto, situação de risco pessoal e social associados ao uso de drogas etc. Realiza ações conjuntas no território para fortalecer as possibilidades de inclusão da família em uma organização de proteção que possa contribuir para a reconstrução da situação vivida (BRASIL, [2020]). 
e 5.184 Unidades de Acolhimento (BRASIL, 2016). A extensão dessa rede de proteção social necessita de uma formação ampla para garantir a qualidade dos atendimentos prestados.

Ainda segundo o Censo Suas 2015 (BRASIL, 2016), foi possível traçar um painel abrangente sobre o perfil dos trabalhadores da rede socioassistencial. No que se refere à escolaridade, no âmbito da gestão municipal, eram 37.283 trabalhadores com ensino fundamental, 115.863 com ensino médio e 91.332 com ensino superior, totalizando 244.478 trabalhadores nessa esfera. No âmbito da gestão estadual, havia 2.254 trabalhadores com ensino fundamental, 5.805 com ensino médio e 5.558 com ensino superior, perfazendo um total de 13.617. Os dados se referem a um universo de 258.095 trabalhadores respondentes à pesquisa.

Em relação ao vínculo empregatício, no âmbito da gestão municipal, o Censo Suas 2015 aponta que os trabalhadores com ensino fundamental se classificavam em estatutários $(41,67 \%)$, celetistas (11,30\%), comissionados (10,65\%) e outros (36,39\%). Somando-se os cargos comissionados e outros vínculos (consultores, servidores cedidos, terceirizados, estagiários etc.), tem-se 47,04\% de vínculo, ou seja, há um grande contingente baseado em contratações mais frágeis e menos estáveis (BRASIL, 2016).

Quando se analisam os dados dos trabalhadores com ensino médio, tem-se: estatutários (30,83\%), celetistas (10,57\%), comissionados (16,35\%) e outros (42,25\%), isto é, novamente se observa a prevalência de vínculos não estáveis, somando-se comissionados e outros, o que equivale a 58,06\%. Em relação a trabalhadores com ensino superior, no âmbito da gestão municipal, o quadro era o seguinte: estatutários (40,82\%), celetistas (10,95\%), comissionados (18,79\%) e outros (29,44\%). Nesse caso, a porcentagem de trabalhadores com vínculos não estáveis, somando-se comissionados e outros, é de 48,23\%.

Nesse sentido, verifica-se que, em todos os níveis de escolaridade analisados, os percentuais de ocorrência de trabalhadores atuando com vínculos mais frágeis no âmbito da gestão municipal gira em torno de $50 \%$ dos dados identificados. 
No âmbito da gestão estadual, observou-se uma atenuação desse quadro; porém, os índices continuam altos entre os participantes do Censo Suas 2015. Para trabalhadores com ensino fundamental, os dados informam: estatutários (59,32\%), celetistas (15,79\%), comissionados (4,61\%) e outros (20,28\%), sendo $24,89 \%$ a soma das proporções de comissionados e outros (BRASIL, 2016).

Para trabalhadores com ensino médio, na gestão estadual, os dados são: estatutários (42,12\%), celetistas (25,06\%), comissionados (13,87\%) e outros (19,95\%), perfazendo um total de 32,82\% de vínculo não estável. O índice se amplia na análise dos dados de trabalhadores com ensino superior: estatutários (41,67\%), celetistas (7,68\%), comissionados (25,75\%) e outros (24,90\%), representando 50,65\% de vínculos frágeis no âmbito da gestão estadual. ${ }^{8}$

Assim, a política de assistência social, fruto das deliberações e debates desenvolvidos nas Conferências Nacionais de Assistência Social, busca fortalecer institucionalmente a gestão do trabalho e a educação permanente no âmbito do Suas, em face de um sistema assistencial que advém de um histórico de fragilidades e precariedade.

Conforme a Política Nacional de Assistência Social - PNAS/2004 (BRASIL, 2004), para que exista qualidade nos serviços socioassistenciais prestados pelo Suas, a gestão do trabalho deve estrategicamente estruturar o trabalho, qualificando e valorizando os profissionais da rede. É explícita a intenção de criar uma rede de qualidade com base na educação permanente, em que a gestão do trabalho tenha papel fundamental:

Assim, para atender aos princípios e diretrizes estabelecidos para a política de Assistência Social, a gestão do trabalho no SUAS deve ocorrer com a preocupação de estabelecer uma Política Nacional de Capacitação, fundada nos princípios da educação permanente, que promova a qualificação de trabalhadores, gestores e

8 É importante esclarecer que o entendimento aqui exposto não é no sentido de que os estatutários e celetistas estejam isentos de relações trabalhistas precarizadas, mas, comparativamente, reconhecemos que os cargos comissionados e outros, de fato, constituem vínculos mais frágeis e não estáveis. 
conselheiros da área, de forma sistemática, continuada, sustentável, participativa, nacionalizada e descentralizada, com a possibilidade de supervisão integrada, visando o aperfeiçoamento da prestação dos serviços socioassistenciais. (BRASIL, 2011, p. 16).

Exige-se, dessa forma, uma estratégia que extrapole os mecanismos meramente gerenciais de capacitação pontual, ou seja, urge realizar a inserção de uma formação crítica e capaz de lidar com a realidade complexa que as demandas sociais apresentam para a rede e que envolve as expressões da questão social. ${ }^{9}$ É no contexto dessa realidade que o profissional da assistência social deve ter a capacidade de prestar atendimento e auxílio na defesa de direitos. A gestão do trabalho proposta pela NOB-RH/Suas/2006 visa a “desprecarização” dos vínculos de trabalho no Suas e a garantia de educação permanente para os trabalhadores (SILVEIRA, 2011).

O Censo Suas 2015 (BRASIL, 2016) também aponta um alto índice de precarização do vínculo (somando-se os dados de comissionados, consultores, servidores cedidos, terceirizados, estagiários etc.), totalizando cerca de 50\% no âmbito da gestão municipal, considerando-se os três níveis de escolaridade. Em relação à gestão estadual, os vínculos não estáveis abrangem $24,89 \%$ dos trabalhadores com ensino fundamental, 32,82\% dos trabalhadores com ensino médio e 50,65\% daqueles com ensino superior.

Nesse sentido, as questões do mundo do trabalho afetam profundamente as relações de trabalho na assistência social, sendo possível identificar tendências de precarização dos vínculos dos técnicos em suas estruturas. Apesar disso, o Censo Suas (2015) demonstra que,

9 Para Iamamoto e Carvalho (1995), a questão social “[...] não é senão as expressões do processo de formação e desenvolvimento da classe operária e de seu ingresso no cenário político da sociedade exigindo seu reconhecimento como classe por parte do empresariado e do Estado. É a manifestação, no cotidiano da vida social, da contradição entre o proletariado e a burguesia, a qual passa a exigir outros tipos de intervenção mais além da caridade e da repressão” (p. 77). 
[...] ao longo dos últimos anos, é possível observar, com relação à quantidade de trabalhadores das Secretarias Municipais de Assistência Social em todo o Brasil, que houve gradativo aumento em números absolutos. Os dados mostram que o quantitativo partiu de aproximadamente 221 mil trabalhadores em 2010 e passou para mais de 256 mil em 2014, o que representa incremento de 36 mil novos profissionais atuando nos municípios ao longo desses anos. (BRASIL, 2016, p. 103).

Nos municípios, a questão é ainda mais crítica, visto que o grau de rotatividade e despreparo para as funções é alto, existindo também um grande número de vínculos frágeis (comissionados, consultores, servidores cedidos, terceirizados, estagiários etc.), o que torna difícil a garantia de direitos (SILVEIRA, 2011). No Censo Suas 2015 (BRASIL, 2016), percebe-se que existe uma queda acentuada na porcentagem de técnicos com vínculo obtido por concurso público, como servidores estatutários nas Secretarias Municipais de Assistência Social. Os dados mostram que, em 2014, houve 35,1\% de redução de servidores estatutários, enquanto se verificou um crescimento de 37\% de técnicos com vínculos não estáveis.

Em vista dessas circunstâncias de instabilidade do vínculo de trabalho, a assistência social pleiteia, por meio do Conselho Nacional Assistência Social (CNAS), a institucionalização de serviços socioassistenciais pela Resolução CNAS nº 109/2009, que aprova a tipificação desses serviços. Dessa forma, a assistência social coloca em jogo a necessidade de ter equipes de gestão preparadas para a execução de serviços que agora são socioassistenciais, reconhecidos pela rede de assistência social.

Em relação à formação dos técnicos, de acordo com o Censo Suas 2015, “analisando a série histórica, identifica-se crescimento do percentual dos que concluíram o Ensino Superior e encolhimento do percentual de trabalhadores que possuem apenas o Ensino Fundamental” (BRASIL, 2016, p. 108). Nesse sentido, a porcentagem de profissionais nas Secretarias Municipais de Assistência Social saltou de 30,7\% com escolaridade de nível superior em 2010, para 35,5\% em 2014. Os trabalhadores com nível médio de escolaridade passaram de 45,7\% em 
2010 para 48,9\% em 2014. No caso dos profissionais com nível fundamental, houve um decréscimo de 23,7\% em 2010 para 15,6\% em 2014.

Nesse contexto, a formação das equipes de referência, em oposição ao trabalho individual, é fortalecida pelas Resoluções CNAS n 17/2011 (CNAS, 2011a) e $n^{\circ}$ 6/2014 (CNAS, 2014), que ratificam as equipes de referência e reconhecem as categorias profissionais de nível superior. As equipes de referência do Suas

[s]ão aquelas constituídas por servidores efetivos responsáveis pela organização e ofertas de serviços, programas, projetos e benefícios de proteção social básica e especial, levando-se em consideração o número de famílias e indivíduos referenciados, o tipo de atendimento e as aquisições que devem ser garantidas aos usuários. (CNAS, 2011b, p. 2).

Essas equipes têm um perfil profissional destacado na NOB-RH/ Suas/2006, ratificado pela Resolução ${ }^{0}$ 17, de 20 de junho de 2011 (CNAS, 2011a), que se definem em dois tipos de funções, a saber, as de serviços socioassistenciais: assistente social, psicólogos, advogados, antropólogos, economista doméstico, pedagogo, sociólogo, terapeuta ocupacional e musicoterapeuta, e as de gestão: assistente social, psicólogo, advogado, administrador, antropólogo, contador, economista doméstico, pedagogo e sociólogo. Assim, a assistência social busca o caminho da profissionalização em seus serviços.

\subsection{A Política Nacional de Educação Permanente para Trabalha- dores do Suas - uma política necessária}

A Política Nacional de Educação Permanente para Trabalhadores do Suas (PNEP/Suas) é uma política construída no âmbito da assistência social, respeitando orientações anteriores postas na Política Nacional de Assistência Social - PNAS/2004 e na Lei Orgânica da Assistência Social - Loas (1993), pautadas nos três níveis de governo e nas Conferências Nacionais da Assistência Social, até serem aprovadas (BRASIL, 
2013). Essa política tem como público-alvo os trabalhadores do Suas com ensino fundamental, médio e superior que atuam na rede socioassistencial governamental e não governamental, além de contemplar gestores e agentes de controle social. ${ }^{10}$

A PNEP/Suas possui diretrizes, objetivos e princípios que visam atingir metas relacionadas à qualidade dos serviços e acompanhamento das novas demandas sociais, objetivando uma mudança nos paradigmas históricos da assistência social. Essa mudança está relacionada ao trabalhador do Suas e reconhece seu protagonismo, qualificação e competência profissional.

A PNEP define educação permanente como

[...] o processo contínuo de atualização e renovação de conceitos, práticas e atitudes profissionais das equipes de trabalho e diferentes agrupamentos, a partir do movimento histórico, da afirmação de valores e princípios e do contato com novos aportes teóricos, metodológicos, científicos e tecnológicos disponíveis. Processo esse mediado pela problematização e reflexão quanto às experiências, saberes, práticas e valores pré-existentes e que orientam a ação desses sujeitos no contexto organizacional ou da própria vida em sociedade. (BRASIL, 2013, p. 34).

Esse conceito de educação permanente foi constituído e debatido por grupos de trabalho ao longo das Conferências Nacionais de Assistência Social, em um processo de ampla discussão realizada com trabalhadores da área, com o objetivo de encontrar uma perspectiva

${ }^{10}$ No âmbito deste trabalho, entende-se por controle social a possibilidade da participação dos cidadãos e da sociedade na execução e acompanhamento das políticas sociais, que ocorre, segundo Perez e Passone (2010), paralelamente ao processo de elaboração e implementação das políticas sociais. “[...] o período de redemocratização se caracterizou pela reforma administrativa do Estado, que envolveu a descentralização e a municipalização de políticas públicas e, também, a institucionalização do controle social, com a criação de conselhos e espaços públicos de interlocução e cogestão política, bem como a mobilização e participação social de diversos setores da sociedade civil” (PEREZ; PASSONE, 2010, p. 1). 
político-pedagógica que atendesse às reais demandas por uma formação crítica e compreendesse a realidade do trabalho na assistência social.

A educação permanente é uma proposta de educação compartilhada, na qual ensino e aprendizagem se congregam no dia a dia do trabalho e da instituição. Essa perspectiva visa a transformação das práticas laborais e da organização a partir da reflexão e ação dos sujeitos, por meio de uma práxis inovadora e reflexiva, com foco no desenvolvimento de elevados níveis de consciência do sujeito-trabalhador acerca de seu processo de trabalho. Ou seja, é por meio dessa práxis que se espera a instituição de novas formas de ser e agir, com base em uma nova consciência de si e de seu labor (SILVA et al., 2010).

Nesse contexto, a proposta de uma educação permanente pode contribuir para o desenvolvimento de uma nova prática para os trabalhadores do Suas, em uma perspectiva de desenvolvimento pessoal e da coletividade, pela transformação que essa prática pode propiciar para o indivíduo e para os demais.

A concepção marxista de práxis se refere ao processo dialético de modificação material que o ser humano realiza pela transformação da natureza, modificando a si próprio, suas relações sociais e a sociedade; é uma atividade de ação-reflexão. Essa atividade, que modifica e transforma a matéria natural e a realidade social, se coloca objetivamente, a partir de fins determinados pela consciência objetiva, pela práxis, pela ação-reflexão-ação (VÁZQUEZ, 2007).

É dessa maneira que as bases de uma educação permanente se instituem, buscando, por meio da ação-reflexão da realidade do trabalho, a transformação dos serviços prestados, com desenvolvimento de uma nova consciência e engajamento por parte dos sujeitos-trabalhadores.

Podemos notar que a PNEP/Suas (2013), por meio dessa concepção de educação permanente, pretende compreender a realidade institucional e possibilitar que o trabalhador crie estratégias a partir da sua realidade para lidar com as demandas de trabalho, com base na institucionalização da educação permanente. O objetivo geral da PNEP é “institucionalizar, no âmbito do Suas, a perspectiva político-pedagógica e a cultura da Educação Permanente [...]” (BRASIL, 2013, p. 27). 
A política de educação permanente do Suas possui 11 objetivos específicos a serem alcançados, sendo eles:

1) Desenvolver, junto a trabalhadores e conselheiros, condições para estes que possam distinguir e fortalecer a centralidade dos direitos socioassistenciais do cidadão no processo de gestão e no desenvolvimento das atenções em benefícios e serviços.

2) Desenvolver, junto a trabalhadores da Assistência Social, as competências e capacidades específicas e compartilhadas requeridas para a melhoria e qualidade continuada da gestão do Suas e da oferta e provimento dos serviços e benefícios socioassistenciais.

3) Desenvolver, junto a conselheiros da Assistência Social, as competências e capacidades requeridas para a melhoria contínua da qualidade do controle social e da gestão participativa do Suas.

4) Estabelecer mecanismos institucionais que permitam descentralizar para estados, municípios e Distrito Federal atribuições relacionadas ao planejamento, oferta e implementação de ações de formação e capacitação.

5) Estabelecer mecanismos institucionais que permitam a participação de trabalhadores e usuários do Suas, de conselheiros da Assistência Social e das instituições de ensino que formam a Rede Nacional de Capacitação e Educação Permanente do Suas nos processos de formulação de diagnósticos de necessidades, planejamento e implementação das ações de formação e capacitação.

6) Criar mecanismos que gerem aproximações entre as manifestações de usuários e o conteúdo das ações de capacitação e formação.

7) Ofertar a trabalhadores percursos formativos e ações de formação e capacitação adequadas às qualificações profissionais requeridas pelo Suas.

8) Ofertar aos conselheiros de Assistência Social ações de formação e capacitação adequadas às qualificações requeridas ao exercício do controle social. 
9) Criar meios e mecanismos de ensino e aprendizagem que permitam o aprendizado contínuo e permanente de trabalhadores do Suas nos diferentes contextos, por meio da experiência no trabalho.

10) Criar meios e mecanismos institucionais que permitam articular o universo do ensino, da pesquisa e da extensão ao universo da gestão e do provimento dos serviços e benefícios socioassistenciais, de forma a contribuir para o desenvolvimento das competências necessárias à contínua e permanente melhoria da qualidade do Suas.

11) Consolidar referências teóricas, técnicas e ético-políticas na Assistência Social a partir da aproximação entre a gestão do Suas, o provimento dos serviços e benefícios e instituições de ensino, pesquisa e extensão, potencializando a produção, sistematização e disseminação de conhecimentos.

Esses objetivos específicos devem ser observados para a delimitação do campo de análise da política, servindo como base para avaliação crítica das ações em andamento por meio do programa de capacitação (CapacitaSuas), que se encontra em outra fase de implantação.

\section{A Institucionalização da Educação Permanente}

\subsection{O CapacitaSuas: um programa de experiência em Educa-} ção Permanente

Em relação à implementação político-institucional e com base nos princípios normativos relacionados ao desenvolvimento dos programas de assistência social, é a partir da regulamentação constante na CF/88, na Lei no 8.742/1993, no PNEP/Suas (2013), na PNAS (2004), na NOB/ Suas/2005, na NOB-RH/Suas/2006 e nas deliberações das Conferências 
Nacionais que se estrutura o Programa Nacional de Capacitação do Sistema Único da Assistência Social (CapacitaSuas). ${ }^{11}$

Esse programa é um instrumento de apoio aos estados e ao Distrito Federal para a implementação dos Planos Estaduais de Capacitação do Suas, que têm por objetivo aprimorar o avanço da gestão por meio da qualificação dos técnicos responsáveis pela prestação dos serviços e benefícios socioassistenciais, com base na concepção político-pedagógica da educação permanente. A Lei Orgânica da Assistência Social - Loas (BRASIL, 1993), em seu artigo 24, prevê que

[os] programas de assistência social compreendem ações integradas e complementares com objetivos, tempo e área de abrangência definidos para qualificar, incentivar e melhorar os benefícios e os serviços assistenciais. (BRASIL, 1993, p. 1).

A referida legislação, ao instituir o Suas como modelo de gestão da assistência social no país, estabeleceu como objetivo desse sistema a implementação da Gestão do Trabalho e a Educação Permanente na Assistência Social. Em conformidade com esse objetivo, o CapacitaSuas foi construído pelas demandas dos trabalhadores da assistência social, com a finalidade de capacitar e apresentar propostas de educação permanente para os trabalhadores do Suas que participam do processo de prestação de serviços e benefícios socioassistenciais (gestores, técnicos e integrantes de conselhos), visando a construção de um novo perfil profissional, pautado na ética e com compromisso com a prestação dos serviços socioassistenciais (BOAS; FERRARI; CASTRO, 2015).

Nesse sentido, o programa se baseia, segundo dispõe a CF/88, na organização do tripé da Seguridade Social, responsável pela execução de programas, serviços e projetos continuados em conjunto com a saúde

${ }^{11}$ O Programa Nacional de Capacitação do SUAS - CapacitaSUAS foi instituído em 2012, por meio da Resolução CNAS nº 8, de 16 de março de 2012, e da Portaria Ministerial $n^{\circ} 142$, de 5 de julho de 2012, do Ministério do Desenvolvimento Social e Combate à Fome - MDS, atualizado nos termos da Resolução CNAS n 28, de 14 de outubro de 2014 (BRASIL, 2015). 
e previdência, conforme previsto em seu marco regulatório, definindo práticas de gestão do trabalho que visam comprometer os profissionais na garantia de direitos e deveres aos trabalhadores do Suas (BOAS; FERRARI; CASTRO, 2015).

O CapacitaSuas tem como público-alvo técnicos da rede pública e privada que atuam na assistência social, bem como gestores da rede de prestação de serviços e benefícios socioassistenciais e membros conselheiros no exercício de suas atribuições e responsabilidades. Essa oferta de qualificação aos trabalhadores da assistência social é uma demanda que surge no âmbito da primeira Conferência Nacional de Assistência Social, em 1995. Conforme pactuado pela Comissão Intergestora Tripartite (CIT), o cofinanciamento dessa ação foi realizado por meio de transferências de recursos financeiros do próprio MDS e de recursos financeiros destinados à execução do CapacitaSuas no âmbito dos estados e do Distrito Federal, cuja meta inicialmente traçada para o exercício de 2012 era alcançar cerca de 37 mil trabalhadores do Suas (BRASIL, 2015).

Sobre a operacionalização do CapacitaSuas e seu arranjo institucional, ficou estabelecido que a coordenação tem o objetivo de promover a qualificação dos trabalhadores do Suas, estruturando as equipes do MDS, especificamente o Departamento de Formação e Disseminação (DFD) e o Departamento de Gestão do Suas (DGSuas), para, de maneira colaborativa, implementar a primeira proposta do programa, juntamente com a equipe do Fundo Nacional de Assistência Social (FNAS), responsável pela estruturação do arranjo financeiro estabelecido na Resolução CNAS n ${ }^{\circ}$ 8, de 16 de março de 2012, que institui o programa de maneira oficial (CRUS, 2015).

Dessa forma, Crus (2015) afirma que

[n]os últimos anos, a consolidação desses avanços e a superação de novos desafios, em especial, do Sistema Único de Assistência Social (SUAS), vêm requerendo uma estratégia ainda mais vigorosa e continuada de formação e qualificação dos trabalhadores envolvidos na prestação dos serviços e programas. É nesse contexto que se formulou em 2012 o Programa Nacional de 
Capacitação do SUAS (CapacitaSuas), com o objetivo de desenvolver as competências necessárias à melhoria da qualidade da gestão, dos serviços e dos benefícios ofertados. (CRUS, 2015, p. 5).

As habilidades e atitudes necessárias aos trabalhadores do Suas estão relacionadas à compreensão da totalidade das relações sociais nas quais estão inseridos os processos de trabalho, que por sua natureza se envolvem com as expressões da questão social. Para compreender a subjetividade desses processos de trabalho, partimos da perspectiva de Lukács (2004) na qual conhecimentos e habilidades em confronto com o mundo permitem ao sujeito verificar a validade de seus saberes e o desenvolvimento e aquisição de novos conhecimentos.

Portanto, o programa CapacitaSuas visa o aprimoramento das funções exercidas, das capacidades e competências gerenciais, prestação de serviços, programas e projetos, benefícios e transferência de renda no âmbito do Suas. A estrutura de coordenação federativa desse programa estabelece a responsabilidade de uma equipe de coordenação nacional sob a égide da Sagi (Secretaria de Avaliação e Gestão da Informação) e da SNAS (Secretaria Nacional de Assistência Social), bem como as respectivas equipes de coordenação nos estados e no Distrito Federal, as quais estarão sob a responsabilidade das secretarias de assistência social.

No que se refere à estrutura de financiamento, o mecanismo institucional é a transferência de recursos financeiros e orçamentários da União, ${ }^{12}$ com base no cofinanciamento federal dessas ações de capacitação, utilizando-se o FNAS diretamente para os Fundos Estaduais de Assistência Social (Feas), desde que o ente federativo tenha se credenciado por meio do Termo de Aceite do CapacitaSuas, ${ }^{13}$ documento que

12 No ano de 2013, o MDS destinou cerca de R \$ 27,3 milhões ao CapacitaSuas, visando capacitar trabalhadores, gestores e conselheiros de Assistência Social com o objetivo de qualificar os serviços e benefícios ofertados à população (CAPACITASUAS, 2013).

${ }^{13}$ Segundo Crus (2015, p. 29): "Esse documento estabelece as responsabilidades das coordenações estaduais do programa: 1) formular os planos estaduais de capacitação, diagnóstico de necessidades e demandas de formação e capacitação, e enviá-los 
credencia e define as responsabilidades dos entes estaduais em relação ao cofinanciamento federal.

A execução do programa fica a cargo das Instituições de Ensino Superior (IES) cadastradas que fazem parte da Rede Nacional de Capacitação e Educação Permanente do Suas (Renep/Suas). Essa rede foi criada em 2012, por meio de chamada pública de responsabilidade da Sagi/ MDS, com o objetivo de cadastrar as entidades executoras do programa.

Em 2014, foi realizada uma segunda chamada pública para ampliar a capacidade do programa e atingir a maior parte das Unidades da Federação (UF), aumentando sua capilaridade para estados como Acre, Tocantins e Rondônia, contando também com a inclusão dos Institutos Federais de Ciência e Tecnologia (Ifets) e das Escolas de Governo.

A Renep/Suas serve como base para que o MDS, os entes estaduais e o Distrito Federal realizem as contratações, conforme as normas estabelecidas, das entidades cadastradas para a execução das ações pertinentes ao programa, tais como (Resolução CNAS nº 4/2013):

a) elaboração de diagnósticos de necessidades de qualificação;

b) planejamento instrucional de ações de formação e capacitação;

c) estruturação de observatórios de práticas;

d) estruturação de núcleos de pesquisa dedicados a diferentes temas afetos ao SUAS;

e) oferta e execução de cursos em várias modalidades, na perspectiva da formação permanente. (CNAS, 2013, p. 35).

à coordenação nacional; 2) execução das ações em seu território; 3) gerir os contratos ou quaisquer outros instrumentos usados para definir a relação com as instituições executoras do CapacitaSUAS; 4) pactuar com os municípios de sua jurisdição a distribuição das metas de capacitados e responsabilidades relativas à execução do programa em nível local. A coordenação nacional, por sua vez, tem as seguintes responsabilidades: 1) identificar as demandas comuns e mais recorrentes expressas nos Planos Estaduais de Capacitação; 2) pactuar com os estados as metas de capacitados, o montante de recurso a ser transferido a título de cofinanciamento federal e outras responsabilidades relativas à execução do programa; e 3) elaborar os projetos pedagógicos dos cursos e disponibilizá-los às coordenações estaduais.” 
Assim, realizou-se a $1^{\text {a }}$ etapa da pactuação do CapacitaSuas, com a intenção de fortalecer as equipes de gestão do trabalho do Suas a partir dos planos estaduais de capacitação enviados ao MDS, que, após análise e sistematização das demandas mais recorrentes, formulou as primeiras ofertas dos cursos do programa. A CIT foi a responsável por definir, por meio da Resolução ${ }^{\circ}$ 1, de 29 de fevereiro de 2012, os critérios e procedimentos destinados ao cofinanciamento federal, determinando os montantes financeiros ${ }^{14}$ a serem transferidos, a forma de adesão e a prestação de contas.

A etapa de monitoramento e avaliação do CapacitaSuas é uma das fases mais importantes do programa, pois possibilita verificar as dificuldades na implementação e corrigi-las para as próximas etapas. A estrutura de análise dessa etapa leva em consideração as especificidades de uma execução descentralizada em âmbito nacional, com diferentes atores, diferentes atribuições e características regionais. Nesse sentido, a responsabilidade institucional na execução dessa tarefa fica a cargo da Sagi, que se relaciona à arquitetura de avaliação, monitoramento e gestão da informação, enquanto outros órgãos também realizam esse processo. É importante ressaltar que “os estados e o DF possuem metodologias e instrumentos próprios de monitoramento do Programa CapacitaSuas” (BOAS; FERRARI; CASTRO, 2015, p. 112).

O monitoramento é uma etapa da própria gestão do programa, sendo o acompanhamento realizado de maneira sistemática pelo MDS e registrado nos sistemas de monitoramento dos processos gerenciais para verificação da etapa de implementação do programa, ${ }^{15}$ dos obje-

14 “Entre 2012 e 2013 foram repassados R\$ 57.389.808,00 aos Estados, por meio de transferências do FNAS para os FEAS, a título de cofinanciamento das ações do CapacitaSUAS. No final de 2014 foram empenhados mais R \$ 29.024.616,00, sendo valor unitário base do cofinanciamento federal por vaga de $\mathrm{R} \$ 600,00$, com ressalva de que os Estados do Norte recebem o valor de R\$720,00, um acréscimo de 15\% em razão das especificidades regionais” (BOAS; FERRARI; CASTRO, 2015, p. 31).

15 “O SIGE é um Sistema de Monitoramento de Programas e Projetos desenvolvido pela SAGI que possibilita aos gestores nacionais do Programa o acompanhamento sistemático da execução em cada estado, capaz de receber as informações das capacitações executadas pelos parceiros da RENEP-SUAS, tratá-las e gerar relatórios 
tivos e das metas estabelecidas, detectando problemas e desafios na consecução do escopo de formação dos trabalhadores. Dessa forma, Boas, Ferrari e Castro (2015) caracterizam as ações de monitoramento do Capacita Suas:

a) construção de instrumento próprio de monitoramento para execução presencial dos cursos, contemplando basicamente dois itens: infraestrutura (condições físicas das salas de aula, acessibilidade, alimentação, alojamentos), e aspectos pedagógicos (respeito à matriz pedagógica acordada, dialogicidade, atividades pedagógicas desenvolvidas, favorecimento da aprendizagem significativa);

b) visitas técnicas de monitoramento para aplicação do instrumento e;

c) elaboração e sistematização de relatórios de monitoramento. (BOAS; FERRARI; CASTRO, 2015, p. 33-34).

Também estão previstos monitoramentos presenciais por parte da equipe técnica do MDS, nos locais de realização das ações de capacitação e formação dos trabalhadores do Suas, os quais também têm a participação ativa de técnicos que representam as coordenações regionais, resultando em relatórios de acompanhamento regulares que subsidiam a coordenação nacional na avaliação e no monitoramento do CapacitaSuas.

Outros critérios de avaliação são baseados na perspectiva de compreensão da ação formativa, que compreende os seguintes aspectos: a) reação subjetiva - satisfação dos participantes com a capacitação; b) apreensão de conteúdos; c) utilidade das habilidades para a prática profissional; d) mudanças em nível organizacional; e) resultado final na prestação de serviços e benefícios socioassistenciais (BOAS; FERRARI; CASTRO, 2015, p. 34).

que abordem o planejamento da oferta, a estrutura dos cursos, o cronograma de execução, a composição das turmas, o controle de desistências, substituições, evasões e frequência dos participantes, o local de realização, o cadastro do perfil dos participantes” (BOAS; FERRARI; CASTRO, 2015, p. 33). 
Durante os cursos, realizam-se avaliações de aprendizagem aplicadas pelo professor, em conformidade com a perspectiva pedagógica enquanto ação processual, permitindo depois reflexões coletivas a respeito das práticas cotidianas de trabalho no âmbito do Suas. Ao final do curso, é realizada, ainda, uma avaliação em cada turma, buscando aferir as percepções dos participantes sobre os aspectos didáticos e de infraestrutura, entre outros. Essas informações auxiliam no aprimoramento da oferta de novas turmas.

Na fase de execução, são utilizados relatórios de visitas técnicas, nos quais se procura compreender o processo de execução dos cursos por meio de dados comparativos, visando dar apoio às entidades executoras no aprimoramento da oferta dos cursos do CapacitaSuas, identificando necessidades de ajustes nos conteúdos e no projeto pedagógico dos cursos ofertados. Já na fase de finalização, além da avaliação dos participantes em relação à infraestrutura, conteúdos e didática, realiza-se a avaliação da aprendizagem pelo professor, para conhecer a percepção do docente sobre o curso e a turma e aspectos de aprendizagem. Também são elaborados relatórios estaduais com a sistematização das avaliações, descrevendo de maneira minuciosa desde aspectos pedagógicos até questões de infraestrutura, com as respectivas recomendações.

\subsection{A implementação do CapacitaSuas: resultados, dificulda- des e desafios}

Conforme nossa proposta de percurso metodológico, diante da natureza complexa da temática, delimitou-seum recortetemporal dapesquisa, demarcando o período de constituição da Política Nacional de Assistência Social (PNAS), em 2004, até a divulgação do Censo Suas 2015.

Nesse sentido, em relação ao CapacitaSuas, é importante destacar que, até dezembro de 2014, todos os estados e o Distrito Federal já haviam aderido formalmente ao programa, com 13.568 trabalhadores certificados e 10.728 em processo de capacitação. Esse conjunto de 24.296 trabalhadores representa 65,55\% do total da meta de 37.062 trabalhadores capacitados, estabelecida na primeira etapa de pactuação com os estados (BOAS; FERRARI; CASTRO, 2015, p. 38). 
Nesse processo de avaliação do CapacitaSuas, observaram-se alguns desafios na implementação do programa. Como exemplo, no âmbito de vários entes federativos, ainda não se tinha estruturado adequadamente uma área de formação e capacitação, o que ocasionou certo atraso na implementação das ações. Outro aspecto formal de dificuldade foi a compreensão jurídica diversa por parte de alguns estados, o que implicou relativa demora na formalização dos contratos entre os entes estaduais e as IES para execução do programa.

Também como desafio na implementação do CapacitaSuas, cita-se a dificuldade, observada em âmbito estadual, na elaboração dos Termos de Referência (TR) para contratação das IES e para acompanhamento e gestão dos contratos formalizados. Para superar esse obstáculo, a Sagi disponibilizou um documento padrão a ser utilizado e ajustado por parte de cada unidade. Também foi prestada assessoria técnica na elaboração dos documentos, em cada região (BOAS; FERRARI; CASTRO, 2015).

Outra dificuldade encontrada na implementação do programa foi a escassez de docentes com experiência acadêmica nos temas relacionados ao Suas, incluindo a compreensão sobre os avanços e normatizações da política. Para contornar essa escassez, foi necessária a realização de oficinas de alinhamento, nas quais se discutiram e se aprimoraram os instrumentos didáticos e os projetos pedagógicos, com a participação de consultores especializados.

As oficinas representam espaços de discussão sobre o cotidiano na execução dos serviços socioassistenciais, desconstruindo mitos em relação aos programas sociais e possibilitando a troca de experiências, reforçando a perspectiva pedagógica junto aos professores das IES responsáveis pela execução das ações de capacitação. ${ }^{16}$ A princípio, colocam-se como um momento oportuno para discussão das questões estruturantes do cotidiano dos trabalhadores do Suas, permitindo a

\footnotetext{
${ }^{16}$ Segundo Boas, Ferrari e Castro (2015, p. 38): “A partir de 2014, foi introduzida uma dinâmica de sensibilização dos participantes nas Oficinas de Alinhamento, com a leitura de cartas dos usuários dos programas sociais recebidas pela ouvidoria do MDS, com relatos de situações cotidianas que envolvem a demanda por serviços e benefícios socioassistenciais".
} 
construção de um espaço de reflexão e crítica sobre suas ações (BOAS; FERRARI; CASTRO, 2015).

Os relatórios de visitas técnicas elaborados para o monitoramento da execução presencial dos cursos mostram que os resultados foram bastante satisfatórios, principalmente no que se refere à avaliação positiva dos aspectos pedagógicos e de infraestrutura. ${ }^{17}$ No que concerne às questões pedagógicas e à relação entre aspectos teóricos e aspectos práticos, observa-se que o princípio da aprendizagem significativa está sendo alcançado, já que as avaliações positivas nesse sentido foram acima da média (BOAS; FERRARI; CASTRO, 2015).

O CapacitaSuas, em consonância com a PNEP/Suas, representa uma tentativa de fortalecimento enquanto instrumento de organização e planejamento das ações de formação e capacitação dos trabalhadores do Suas, os quais enfrentam limitações relacionadas a questões estruturais de condições de trabalho, além de terem de lidar apropriadamente com as expressões da questão social. Um exemplo de limitação estruturante na qual a política esbarra são os vínculos precarizados de trabalho a que estão submetidos os trabalhadores no âmbito do Suas.

Quanto aos resultados, percebe-se imediatamente a reestruturação das equipes técnicas estaduais, gerando maior integração entre estas e o MDS, disseminando a política e a execução das suas ações no âmbito da gestão do trabalho. Nesse sentido é que se colocam os principais desafios para a coordenação nacional do programa, tais como a formação das equipes para o desempenho qualificado de suas atribuições.

Quanto à gestão do programa, os desafios que se apresentam estão relacionados ao modelo de implementação do CapacitaSuas, a partir de uma coordenação nacional responsável pelo planejamento central das atividades formativas, da elaboração dos conteúdos e da gestão financeira e pelo assessoramento técnico na elaboração de documentos normativos. Esse instrumento pretende acabar com a sobreposição

${ }^{17}$ Por exemplo, avaliações positivas de 71\% (sala de apoio); 84\% (sala de aula adequada ao tamanho da turma); $56 \%$ (espaço adequado para as oficinas de aprendizagem); 87\% (garantia de acessibilidade). 
de ações no âmbito das atividades de capacitação e formação dos trabalhadores da assistência social, a partir de um esforço colaborativo e de uma reestruturação institucional.

É importante destacar que os estados exerceram um papel significativo no âmbito da implementação da PNEP/Suas, desde a realização do diagnóstico de necessidades de formação em nível regional e local que levou à elaboração dos respectivos planos estaduais de capacitação, mobilizando os trabalhadores e gerenciando os contratos com as entidades executoras (BOAS; FERRARI; CASTRO, 2015).

Outro resultado expressivo da implementação do CapacitaSuas foi a estruturação de uma rede de instituições em nível nacional, incluindo previamente o credenciamento e habilitação das entidades de ensino superior para ministrar os cursos definidos a partir de critérios específicos, colocando em consonância a gestão de políticas sociais com a universidade. As oficinas de alinhamento permitem, ainda, que os participantes da Renep/Suas possam realizar a troca de experiências e percepções em relação ao programa (BOAS; FERRARI; CASTRO, 2015).

Nesse sentido, Boas, Ferrari e Castro (2015, p. 42) apontam os principais desafios para a continuação do programa, que incluem a busca pelo fortalecimento das equipes dos estados responsáveis pelas ações de formação e capacitação; o aprimoramento no assessoramento técnico diante das mudanças de governos e de gestão estadual; a ampliação da oferta de programas de formação para as entidades da Renep/Suas; a garantia de compartilhamento contínuo de experiências e monitoramento das demandas constantes dos planos de educação permanente; o aperfeiçoamento das estratégias de avaliação e monitoramento no âmbito da política; e a realização da articulação e mobilização contínua das IES cadastradas na Renep/Suas, para que ampliem a temática localmente por meio do ensino, pesquisa e extensão.

\subsection{Análise de algumas experiências no âmbito do CapacitaSuas}

Neste tópico, busca-se discutir algumas experiências estaduais a partir das publicações disponibilizadas pelo MDS em sua página institucional, 
visando apresentar os resultados da implementação do CapacitaSuas em algumas Unidades da Federação. Nesse sentido, foram encontradas publicações sobre a implementação da $1^{\text {a }}$ fase do CapacitaSuas nas UF de Sergipe, Mato Grosso do Sul, Acre, Paraná, Mato Grosso e Distrito Federal. Esse programa se estabelece por meio de uma ação colaborativa em nível intersetorial e interfederativo, de maneira dialógica e visando o fortalecimento da participação social nas políticas públicas, o que representa um avanço no sentido do fortalecimento das ações no âmbito das políticas sociais.

Dessa forma, podemos destacar a experiência da operacionalização do CapacitaSuas no estado de Sergipe, no ano de 2013, que teve por foco qualificar os trabalhadores para prestação dos benefícios socioassistenciais, com ênfase nos aspectos de maior relevância no que se refere ao processo de implementação das ações de formação, desde o planejamento, execução, monitoramento e avaliação do programa, até a verificação se seus objetivos institucionais foram alcançados.

A operacionalização do programa no âmbito do estado trouxe uma experiência relevante do ponto de vista do planejamento e da execução, com resultados consistentes coletados na fase de monitoramento e avaliação (MALHEIROS et al., 2014).

No caso da experiência do estado de Mato Grosso do Sul, é importante destacar os relatos apresentados por Verbisck e Zottos (2014), em que, no que se refere ao momento de elaboração do Plano Estadual de Capacitação do Suas (PEC/Suas) do estado de Mato Grosso do Sul (CapacitaSuas/MS), evidenciou-se

[...] a angústia dos profissionais no levantamento das questões relativas às condições de trabalho, expondo vínculos frágeis e apresentando as principais temáticas a serem trabalhadas no âmbito dos municípios. Também revelou a fragilidade na área dos trabalhadores da assistência social responsáveis pela execução e gestão dos serviços, principalmente em relação a seus vínculos empregatícios, o quantitativo das equipes de referência e da gestão e a lacuna no campo da capacitação. (VERBISCK; ZOTTOS, 2014, p. 7). 
No estado de Mato Grosso do Sul, as ações de educação permanente implementadas no ano de 2014 tinham por objetivo inovar no aspecto formativo dos trabalhadores do Suas, o que pode ser verificado na substituição de antigas práticas, notadamente balizadas pela falta de planejamento, inserindo a gestão do trabalho e a educação permanente como instrumentos efetivos de aprimoramento das ações de prestação de serviços socioassistenciais.

Ainda segundo Verbisck e Zottos (2014),

[...] é inegável que o processo de elaboração, planejamento e execução do CapacitaSUAS no Mato Grosso do Sul levou a equipe e os gestores a analisarem o trabalho e seus trabalhadores de forma diferenciada. Apesar de todos os limites e desafios impostos por questões burocráticas, como prazos e procedimentos licitatórios, o processo para organização e execução do CapacitaSUAS até agosto de 2014 ressaltou a atuação e a importância da assistência social do Mato Grosso do Sul na construção das políticas públicas com eficiência e eficácia. A efetividade poderá ser avaliada nos resultados das mudanças nos processos de trabalho. (VERBISCK; ZOTTOS, 2014, p. 20).

Em relação ao índice de participação dos trabalhadores, o nível de execução do CapacitaSuas no âmbito do Mato Grosso do Sul foi de 88\% das metas estabelecidas no termo de referência e de $100 \%$ da meta pactuada no termo de aceite, contando com cerca de $80 \%$ de aprovação, com destaque para a qualidade dos cursos e do conteúdo apontada pelos participantes (VERBISCK; ZOTTOS, 2014).

A experiência da implementação do CapacitaSuas no estado do Acre representa um esforço para o estabelecimento das políticas sociais, tendo em vista que, segundo estimativa do Instituto Brasileiro de Geografia e Estatística (IBGE), em julho de 2014 a população do estado totalizava 790.101 mil habitantes, sendo que 502.246 mil (63,6\%) estavam cadastrados no CadÚnico, ou seja, eram famílias de baixa renda que dependiam da prestação de serviços e benefícios socioassistenciais 
(IBGE, [2017]). Conforme os dados disponibilizados pelas Secretarias Municipais de Assistência Social em 2014, no estado do Acre existiam aproximadamente 412 trabalhadores do Suas com ensino superior, dos quais 250 haviam se inscrito no programa CapacitaSuas, ou seja, 60,7\%; entre estes, 239 (95,6\%) obtiveram desempenho satisfatório nos cursos.

No estado do Paraná, a experiência no âmbito do CapacitaSuas permitiu verificar a situação das condições dos trabalhadores do Suas. Segundo Schafachek et al. (2014),

[e]m 2011, dos 12.780 trabalhadores lotados nos municípios paranaenses, $15 \%$ contava com escolaridade de nível fundamental, 45\% possuíam nível médio e 40\% tinha nível superior. No ano de 2012, ampliou-se o quadro para 13.576 trabalhadores municipais. Em números percentuais, o quadro do nível de escolaridade dos trabalhadores municipais se manteve o mesmo em 2013, embora tenha evoluído numericamente para 14.106 trabalhadores, em números absolutos. (SCHAFACHEK et al., 2014, p. 9).

Os cursos foram realizados em turmas de 20 a 56 participantes, enquanto as oficinas eram compostas de dez a 28 alunos, sendo apresentados relatos dos participantes que demonstraram e corroboraram a importância de "contribuir de forma efetiva e qualificada para instrumentalizar os trabalhadores a enfrentar os desafios e promover o aperfeiçoamento do SUAS” (SCHAFACHEK et al., 2014, p. 19).

No estado de Mato Grosso, a implementação do CapacitaSuas se deu logo após a instituição do programa pelo MDS, no ano de 2012, contexto em que a gestão estadual foi convocada a apresentar o respectivo Plano Estadual de Capacitação dos Trabalhadores do Suas (PEC/ Suas), cuja elaboração ficou a cargo da equipe da Secretaria de Estado de Trabalho e Assistência Social de Mato Grosso (Setas/MT). O Plano foi pactuado na Comissão Intergestores Bipartite (CIB), mediante a Resolução $n^{\circ}$ 11, de 18 de abril de 2012, tendo sido posteriormente aprovado pelo Conselho Estadual de Assistência Social de Mato Grosso 
(Ceas/MT), mediante a Resolução n ${ }^{0}$ 17, de 8 de maio de 2012 (VITORIO; PELLOSO, 2014, p. 10).

Assim, as salas de aula, a infraestrutura física, os aspectos pedagógicos e a matriz de conteúdos foram avaliadas de forma satisfatória, enquanto a metodologia de ensino e as oficinas de aprendizagem foram avaliadas de forma positiva. Dessa forma, segundo Vitorio e Pelloso (2014, p. 16), "tanto os técnicos estaduais quanto os participantes consideraram, no geral, que as matrizes pedagógicas de cada curso foram cumpridas, com as devidas adaptações à realidade local.”

Por fim, no âmbito do Distrito Federal, o órgão responsável pela implementação do CapacitaSuas foi a Secretaria de Estado de Desenvolvimento Social e Transferência de Renda (Sedest), instância estratégica encarregada de executar as políticas de assistência social, transferência de renda e de segurança alimentar e nutricional, no âmbito da gestão do Suas e do Sistema Nacional de Segurança Alimentar e Nutricional (Sisan), além de políticas de inclusão produtiva no âmbito do DF (TORRES; MACHADO; BARBOSA, 2014, p. 7).

Em relação ao contingente de trabalhadores da Sedest, em março de 2014 havia 1.848 servidores no quadro, sendo por volta de 1.200 atuando diretamente com a política de assistência social. No tocante ao grau de instrução, a maior parte possuía ensino superior completo (57\%); destes, 462 tinham especialização (25\%), ou seja, essa secretaria contava com um quadro altamente qualificado e de escolaridade elevada, impactando tal perfil, de certa forma, de maneira positiva na qualidade da prestação dos serviços socioassistenciais. Além disso, havia a priorização, pela secretaria, de uma maioria de servidores efetivos na composição do quadro de pessoal, qualificando o processo de trabalho.

Apesar das avaliações que demonstram o nível de satisfação dos trabalhadores em relação aos cursos, a Sedest identificou, como uma dificuldade recorrente, a questão da frequência, já que a carga horária de trabalho dos participantes era em média de 30 horas semanais, enquanto o curso possuía carga horária de 40 horas semanais. Ainda assim, em situações nas quais trabalhadores atuavam em regime de plantão 
ou em dois órgãos, a secretaria conseguiu alcançar 700 trabalhadores capacitados nessa primeira etapa.

Embora as ações de formação e capacitação do programa CapacitaSuas tenham sido positivamente avaliadas, o atual contexto de precarização trabalhista, resultado das transformações sofridas pelo mundo do trabalho e da (res)significação do papel do Estado enquanto provedor de políticas sociais em uma perspectiva neoliberal de restrição dos direitos sociais, leva a antever um cenário de deterioração imediata das condições dos trabalhadores do Suas, inclusive no que se refere aos seus vínculos funcionais, exigindo uma capacidade de articulação política desse segmento de trabalhadores nos seus respectivos espaços ocupacionais e para além deles.

\section{Considerações finais}

As possibilidades colocadas pela implementação da PNEP/Suas e a complexidade da temática que relaciona educação e trabalho no âmbito da assistência social, por si só, demandariam bem mais que a pretensão de esgotar o tema neste trabalho, sugerindo espaço para novas pesquisas que se relacionem com o objeto deste estudo.

A concepção político-pedagógica da educação permanente para os trabalhadores do Suas leva em consideração as ações profissionais cotidianas, tanto no âmbito da gestão quanto do provimento de serviços e benefícios socioassistenciais. Surgiu como demanda dos trabalhadores no decorrer das Conferências Nacionais que se realizaram a partir de 1995 e esteve nas pautas de discussão das outras reuniões, até a instituição da Política Nacional de Educação Permanente do Suas (PNEP/ Suas), que buscou atender a esse pleito.

Entre os achados da pesquisa, está a concepção da educação permanente enquanto dimensão ética e política para o aprimoramento das ações no campo da proteção social no Brasil, em um momento no qual o receituário neoliberal impõe um sistemático ataque aos direitos sociais dos trabalhadores e dos usuários do Suas. 
O contexto de implementação do programa se coloca como relação institucional e um pacto federativo entre o órgão gestor federal e as Unidades da Federação, para que, na forma de cofinanciamento e no estabelecimento de corresponsabilidades, o programa CapacitaSuas alcance o objetivo de desenvolver as competências necessárias à melhoria da qualidade da gestão, dos serviços e dos benefícios ofertados, consolidando-se como um programa essencial para a estratégia de organizar e planejar as ações de formação e capacitação previstas. Essa demanda levou à criação (em alguns casos) ou à reestruturação das equipes estaduais para o atendimento das ações no âmbito da gestão do trabalho e de suas equipes de referência, colocando-se como um desafio a formação dessas equipes por meio de ações específicas, aprimorando os serviços ofertados por esse conjunto de profissionais.

Dessa forma, a PNEP/Suas contribui para a melhoria da prestação dos serviços e benefícios socioassistenciais por meio da qualificação dos trabalhadores do Suas, apesar de o contexto de reestruturação produtiva impor aos sujeitos desse processo condições precarizadas de inserção e de atuação técnica. Entre essas melhorias, destaca-se a definição da constituição das equipes multidisciplinares, a formação de planos de capacitação a partir das demandas colhidas no âmbito de cada estado e o fortalecimento da transferência de recursos federais e estaduais para pagamento de profissionais que atuam nos municípios, embora ainda seja frágil a quantidade de dados relacionados ao monitoramento e avaliação da execução dos programas, pois a PNEP ainda está em processo de instalação em alguns estados.

A implementação da PNEP/Suas enfrenta as condições estruturais relacionadas à flexibilização do trabalho, às terceirizações e à constituição de relações de trabalho com base em vínculos precários, além da instabilidade financeira, já que depende da pactuação entre governo federal e estados e dos repasses para garantir o financiamento das ações de formação e capacitação. Não obstante, segue-se visando a melhoria da prestação dos serviços e benefícios socioassistenciais, a despeito de um cenário de crescente precarização das condições de trabalho. 


\section{Referências}

ALAGOAS (Estado). Secretaria de Estado da Assistência e Desenvolvimento Social. Centro de Referência da Assistência Social - CRAS. Alagoas: Seades, [2017]. Disponível em: http://www.assistenciasocial. al.gov.br/programas-projetos/protecao-social-basica-1/cras-paif. Acesso em: 21 mar. 2017.

BEHRING, Elaine Rossetti; BOSCHETTI, Ivanete. Política social: fundamentos e história. 7. ed. São Paulo: Cortez, 2010. (Biblioteca Básica de Serviço Social).

BOAS, Patrícia Augusta Ferreira Vilas; FERRARI, Marcílio Marquesini; CASTRO, Antônio Santos Barbosa de. Perspectivas e desafios do programa CapacitaSUAS no contexto de inovação e compromisso com a qualificação dos trabalhadores do SUAS. In: CRUS, José Ferreira da et al. (org.). CapacitaSUAS: os desafios da educação permanente do SUAS. Brasília: Ministério do Desenvolvimento Social e Combate à Fome, 2015. (Cadernos de Estudos Desenvolvimento Social em Debate, n. 22). BRASIL. Assistência Social. Rede de Assistência e Proteção Social: Proteção Social. Brasília: Governo do Brasil, [2020]. Disponível em: https://www.gov.br/pt-br/categorias/assistencia-social/rede-de-assistenciae-protecao-social/protecao-social. Acesso em: 20 maio 2020.

BRASIL. Lei n ${ }^{\circ}$ 8.742. Dispõe sobre a organização da Assistência Social e dá outras providências (Lei Orgânica de Assistência Social - Loas). Diário Oficial da União, Brasília, Seção 1, 8 dez. 1993.

BRASIL. Ministério do Desenvolvimento Social e Combate à Fome. Caderno de Orientações Técnicas Sobre os Gastos no Pagamento dos Profissionais das Equipes de Referência do SUAS. 1. ed. Brasília: Ministério do Desenvolvimento Social e Combate à Fome, 2015, 88 p. Disponível em: www.fas.curitiba.pr.gov.br/baixarMultimidia.aspx?i$\mathrm{df}=9080$. Acesso em: 8 jun. 2017. 
BRASIL. Ministério do Desenvolvimento Social e Combate à Fome. Política Nacional de Educação Permanente do SUAS. 1. ed. Brasília: Ministério do Desenvolvimento Social, 2013. Disponível em: http:// aplicacoes.mds.gov.br/snas/documentos/Politica-nacional-de-Educacaopermanente.pdf. Acesso em: 10 mar. 2017.

BRASIL. Ministério do Desenvolvimento Social e Combate à Fome. Política Nacional de Assistência Social. Brasília: Ministério do Desenvolvimento Social, 2004.

BRASIL. Ministério do Desenvolvimento Social e Combate à Fome. Secretaria Nacional de Assistência Social. Departamento de Gestão do Suas. Censo SUAS 2015: Resultados Nacionais, Centros de Referência da Assistência Social, CRAS. Brasília: Ministério do Desenvolvimento Social e Combate à Fome, mar. 2016.

BRASIL. Ministério do Desenvolvimento Social e Combate à Fome. Secretaria Nacional de Assistência Social. Departamento de Gestão do Suas. NOB-RH/SUAS: anotada e comentada. Brasília: Ministério do Desenvolvimento Social e Combate à Fome, dez. 2011.

CAPACITASUAS já qualificou mais de 2 mil pessoas. Portal do Servidor, Brasília, 11 nov. 2013. Disponível em: https://www.servidor. gov.br/noticias/2015/cursos/capacitasuas-ja-qualificou-mais-de-2-milpessoas. Acesso em: 8 jun. 2017.

CONSELHO NACIONAL DE ASSISTÊNCIA SOCIAL (CNAS). Resolução ${ }^{\circ}$ 17, de 20 de junho de 2011. Ratificar a equipe de referência definida pela Norma Operacional Básica de Recursos Humanos do Sistema Único de Assistência Social - NOB-RH/SUAS e reconhecer as categorias profissionais de nível superior para atender as especificidades dos serviços socioassistenciais e das funções essenciais de gestão do Sistema Único de Assistência Social - SUAS. Diário Oficial da União, Brasília, Seção 1, 21 jun. 2011a. Disponível em: https://www. legisweb.com.br/legislacao/?id=115722. Acesso em: 19 de maio de 2020. 


\section{CONSELHO NACIONAL DE ASSISTÊNCIA SOCIAL (CNAS).}

Resolução nº 269, de 13 de dezembro de 2006. Aprova a Norma Operacional Básica de Recursos Humanos do Sistema Único de Assistência Social - NOB-RH/SUAS. Diário Oficial da União, Brasília, Seção 1, 26 dez. 2006.

CONSELHO NACIONAL DE ASSISTÊNCIA SOCIAL (CNAS). Resolução $n^{\circ}$ 32, de 28 de novembro de 2011. Estabelece percentual dos recursos do SUAS, cofinanciados pelo governo federal, que poderão ser gastos no pagamento dos profissionais que integrarem as equipes de referência, de acordo com o art. $6^{\circ}$-E da Lei n ${ }^{\circ}$ 8.742/1993, inserido pela Lei 12.435/2011. Diário Oficial da União, Brasília, Seção 1, nov. 2011b. Disponível em: http://www.mds.gov.br/webarquivos/legislacao/ assistencia_social/resolucoes/2011/Resolucao\%20n\%20\%2032_de\%20 2011.pdf. Acesso em: 19 maio 2020.

CONSELHO NACIONAL DE ASSISTÊNCIA SOCIAL (CNAS). Resolução no ${ }^{\text {4, de }} 13$ de março de 2013. Institui a Política Nacional de Educação Permanente do Sistema Único da Assistência Social - PNEP/SUAS. Diário Oficial da União, Brasília, Seção 1, 20 mar. 2013. Disponível em: http://www.mds.gov.br/cnas/legislacao/resolucoes/arquivos-2013/ resolucoes-cnas-2013/. Acesso em: 20 maio 2020.

CONSELHO NACIONAL DE ASSISTÊNCIA SOCIAL (CNAS). Resolução $n^{\circ}$ 6, de 20 de março de 2014. Inclui o inciso VI no art. $8^{\circ}$ e altera as redações da Seção IV do Capítulo II e dos arts. 41, 42 e 44 da Resolução $n^{\circ}$ 6, de 9 de fevereiro de 2011, do Conselho Nacional de Assistência Social - CNAS, que aprova o Regimento Interno do CNAS, criando a Comissão de Monitoramento das Deliberações das Conferências Nacionais de Assistência Social. Diário Oficial da União, Brasília, Seção 1, 21 mar. 2014. Disponível em: http://www.mds.gov.br/ cnas/legislacao/resolucoes/arquivos-2014/cnas-2014-006-20-03-2014. pdf/download. Acesso em: 19 maio 2020. 
CONSELHO NACIONAL DE ASSISTÊNCIA SOCIAL (CNAS). Resolução no ${ }^{\circ}$, de 16 de março de 2012. Institui o Programa Nacional de Capacitação do SUAS - CapacitaSUAS e aprova os procedimentos e critérios para adesão dos Estados e do Distrito Federal ao cofinanciamento federal do Programa Nacional de Capacitação do SUAS - CapacitaSUAS. Diário Oficial da União, Brasília, Seção 1, 19 mar. 2012. Disponível em: http://www.mds.gov.br/cnas/legislacao/resolucoes/ arquivos-2012/cnas-2012-008-16-03-2012c.pdf/download. Acesso em: 19 de maio de 2020.

CRUS, José Ferreira da et al. (org.). CapacitaSUAS: os desafios da educação permanente do SUAS. Brasília: Ministério do Desenvolvimento Social e Combate à Fome, 2015. (Cadernos de Estudos Desenvolvimento Social em Debate, n. 22).

IAMAMOTO, Marilda V.; CARVALHO, Raul. Relações Sociais e Serviço Social no Brasil: esboço de uma interpretação histórico-metodológica. 10. ed. São Paulo: Cortez/Celats, 1995.

INSTITUTO BRASILEIRO DE GEOGRAFIA E ESTATÍSTICA (IBGE). Cidades do Acre. Brasília: IBGE, [2017]. Disponível em: https://cidades. ibge.gov.br/brasil/ac/panorama. Acesso em: 9 jun. 2017.

IVO, Anete Brito Leal (coord.); KRAYCHETE, Elsa S.; BORGES, Ângela; MERCURI, Cristiana; VITALE, Denise; SENNES, Stella. Dicionário temático desenvolvimento e questão social: 81 problemáticas contemporâneas. São Paulo: Annablume; Brasília: CNPq; Salvador: Fapesb, 2013. 564 p. (Coleção Trabalho e Contemporaneidade).

LUKÁCS, György. Ontologia del Ser Social: El Trabajo. Compiladores: A. Infranca e M. Vedda. Buenos Aires: Ediciones Herramienta, 2004. 
MALHEIROS, Neusa Nunes; SANTOS, Valéria do Nascimento; MENEZES, Maria Ione Vasconcelos de; FERREIRA, Vera Lúcia de Souza; FELIX, Janaina Lameira. O Programa CapacitaSUAS no Estado de Sergipe: (Re)visitando a experiência de um aprendizado coletivo. Brasília: Ministério do Desenvolvimento Social e Combate à Fome, 2014. (Série textos sobre educação permanente para o desenvolvimento social. Relatos CapacitaSUAS, Caderno 01). Disponível em: https://aplicacoes.mds. gov.br/sagirmps/ferramentas/docs/O\%20Programa\%20Capacitasuas\%20 \%20no\%20Estado\%20de\%20Sergipe-\%20\%20(Re)visitando\%20a\%20 experi\%C3\%AAncia\%20de\%20um\%20aprendizado\%20coletivo.pdf. Acesso em: 9 jun. 2017.

PEREZ, José Roberto Rus; PASSONE, Eric Ferdinando. Políticas sociais de atendimento às crianças e aos adolescentes no Brasil. Cadernos de Pesquisa, São Paulo, v. 40, n. 140, p. 649-673, maio/ago. 2010. Disponível em: http://www.scielo.br/scielo.php?script=sci_arttext\&pid=S010015742010000200017\&lng=en\&nrm=iso. Acesso em: 19 maio 2020.

SCHAFACHEK, Tatiana Possa; KOVALSKI, Hamilton; SCHINEMANN, Rosely Lemos; OLIVEIRA, Monique Cabral de; MASCARIN, Fernanda de Oliveira Pavão. A importância da Educação Permanente para os trabalhadores do SUAS no Estado do Paraná. Brasília: Ministério do Desenvolvimento Social e Combate à Fome, 2014. (Série textos sobre educação permanente para o desenvolvimento social, Caderno 04). Disponível em: http://aplicacoes.mds.gov.br/sagirmps/ferramentas/ docs/A\%20importancia\%20da\%20Educa\%C3\%A7\%C3\%A3o\%20 permanente.pdf. Acesso em: 9 jun. 2017.

SILVA, Luiz Anildo Anacleto da; FERRAZ, Fabiane; LINO, Mônica Motta; BACKES, Vânia Marli Schubert; SCHMIDT, Sandra Márcia Soares. Educação permanente em saúde e no trabalho de enfermagem: perspectiva de uma práxis transformadora. Rev. Gaúcha Enferm., Porto Alegre, v. 31, n. 3, p. 557-61, set. 2010. 
SILVEIRA, Jucimeri Isolda. Gestão do Trabalho: concepção e significado para o SUAS. In: BRASIL. Ministério do Desenvolvimento Social e Combate à Fome. Secretaria Nacional de Assistência Social Gestão do Trabalho no Âmbito do SUAS: Uma contribuição necessária. Brasília: Ministério do Desenvolvimento Social e Combate à Fome, 2011. 176 p.

TANEZINI, Theresa Cristina Zavaris. Parâmetros teóricos e metodológicos para análise de políticas sociais. Revista SER Social, [s. l.], n. 14, p. 13-44, fev. 2010. Disponível em: https://periodicos.unb.br/index. php/SER_Social/article/view/12937. Acesso em: 14 abr. 2017.

TORRES, Denise Riella; MACHADO, Gardênia A. Scapim; BARBOSA, Lídia Cristina. A implantação do CapacitaSUAS no Distrito Federal. Brasília: Ministério do Desenvolvimento Social e Combate à Fome, 2014. (Série textos sobre educação permanente para o desenvolvimento social. Relatos CapacitaSUAS, Caderno 06). Disponível em: https://aplicacoes.mds.gov.br/sagirmps/ferramentas/docs/A\%20 implanta\%C3\%A7\%C3\%A3o\%20do\%20CapacitaSUAS\%20no\%20 Distrito\%20Federal.pdf. Acesso em: 9 jun. 2017.

VÁZQUEZ, Adolfo Sanchez. Filosofia da práxis. São Paulo: Expressão Popular, 2007.

VERBISCK, Ana Carina do Prado Ávila; ZOTTOS, Antonia Raquel Lima Camargo. CapacitaSUAS: Um balanço de experiências e aprendizados no estado de Mato Grosso do Sul. Brasília: Ministério do Desenvolvimento Social e Combate à Fome, 2014. (Série textos sobre educação permanente para o desenvolvimento social. Relatos CapacitaSUAS, Caderno 02). Disponível em: http://aplicacoes.mds.gov.br/sagirmps/ ferramentas/docs/CAPACITASUAS-\%20UM\%20BALAN\%C3\%87O\%20 DE\%20EXPERI\%C3\%8ANCIAS\%20E\%20APRENDIZADOS\%20 NO\%20ESTADO\%20DE\%20MATO\%20GROSSO\%20DO\%20SUL. pdf. Acesso em: 9 jun. 2017. 
VITORIO, Leícy Lucas de Miranda; PELLOSO, Luciana Trugillo. Construindo a Educação Permanente do SUAS em Mato Grosso. Brasília: Ministério do Desenvolvimento Social e Combate à Fome, 2014. (Série textos sobre educação permanente para o desenvolvimento social. Relatos CapacitaSUAS, Caderno 05). Disponível em: https://aplicacoes.mds.gov. br/sagirmps/ferramentas/docs/5_Construindo\%20a\%20Educacao\%20 Permanente\%20do\%20SUAS\%20em\%20MatoGrosso.pdf. Acesso em: 9 jun. 2017.

YAZBEK, Maria Carmelita. Classes subalternas e assistência social. São Paulo: Cortez, 1995. 


\section{Capítulo 6}

\section{As multifaces}

do trabalho

precário no

Sistema Único de

Assistência Social

Regiane Cota e Rocha

Universidade de Brasília (UnB)

regianecota@yahoo.com.br

\section{Introdução}

A instituição da assistência social como política pública a partir da Constituição Federal de 1988 e sua regulamentação mediante a Lei Orgânica de Assistência Social (Loas, 1993) e posteriores normatizações possibilitaram a organização, implantação e implementação dessa política social. 
A bem dizer, a definição de política social parece imprescindível no intuito de delimitar sua natureza constitutiva. A respeito do tema, Pereira-Pereira (2009, p. 171) esclarece: “Trata-se, portanto, a política social, de uma categoria acadêmica e política, de constituição teórica e prática, que não apenas se dispõe a conhecer e explicar o mundo real, mas também a agir neste mundo, visando mudanças.”

O sentido pelo qual se alude à política social, como bem define a autora, é o de "política de ação, que tem perfil, funções e objetivos próprios e produz impacto no campo em que atua” (PEREIRA-PEREIRA, 2009, p. 171), tendo como natureza constitutiva o atendimento de necessidades humanas para a concretização de direitos sociais. Assim,

[...] apesar de o termo política social estar relacionado a todos os outros conteúdos políticos, ele possui identidade própria. Refere-se à política de ação que visa, mediante esforço organizado e pactuado, atender necessidades sociais cuja resolução ultrapassa a iniciativa privada, individual e espontânea, e requer deliberada decisão coletiva regida por princípios de justiça social que, por sua vez, devem ser amparados por leis impessoais e objetivas, garantidoras de direitos. (PEREIRA-PEREIRA, 2009, p. 171-172).

Além disso, é primordial destacar, para a delimitação teórica e política do presente texto, que os caminhos para a construção de direitos sociais não são trilhados por mera espontaneidade do Estado. Ao contrário, são traçados por vias de movimentos políticos que se fizeram e se fazem presentes na história do Brasil, em momentos de pressão política na relação contraditória entre capital e trabalho, e que são contínuos na história da humanidade.

Nesse sentido, compreende-se a conformação da Política de Assistência Social como uma correlação de forças contrárias, conforme Poulantzas (2000), na qual os interesses, as escolhas e as decisões dos trabalhadores são conflitantes com os da classe dominante. Assim emergem as decisões que ora são favoráveis aos explorados, ora são favoráveis aos dominantes. 
Na sociabilidade do mundo do trabalho contemporâneo, os determinantes e contradições da assistência social conduziram a condições de trabalho precarizadas pelo próprio desprestígio dessa política social, remetendo a divergências entre as elaborações legais e o cotidiano em que esse trabalho é desenvolvido.

A dimensão da execução da política, no que se refere à composição dos recursos humanos que a operacionalizam, continua sendo um ponto de destaque que carece de problematização diante da progressiva precarização das condições de trabalho inerente ao modo de produção e reprodução capitalista.

Entre as interlocuções deste texto, entrelaçam-se olhares diversos, que às vezes se encontram e às vezes se distanciam, por observarem o mesmo elemento de maneira diferente.

Considerando que no Brasil há insuficiência de pesquisas que busquem dados primários sobre o tema das condições de trabalho no Sistema Único de Assistência Social (Suas), privilegiou-se, na problematização desse objeto, uma leitura de mundo proveniente da elaboração pessoal dos próprios trabalhadores e trabalhadoras que constroem e vivenciam a assistência social no Distrito Federal. Em concordância com Freire (2008, p. 11), quando este afirma que "a leitura do mundo precede a leitura da palavra”, entende-se aqui que essa elaboração, essa leitura de mundo pelos sujeitos da pesquisa é de tal importância que se evidencia nas condições postas e, por isso, valoriza-se o ato de leitura da realidade vivida pelos entrevistados e entrevistadas que com ela se relacionam em seu cotidiano.

Do ponto de vista da economia política e no limite histórico contemporâneo a que o presente trabalho se refere, parte-se do pressuposto de que as condições de trabalho no sistema vigente e, assim, o próprio trabalho, nos últimos anos, foram influenciados pela reestruturação produtiva e pela política neoliberal que, segundo Duriguetto (2008, p. 83), “são expressões das crises estruturais do capitalismo.” Por conseguinte, a hegemonia capitalista, forjada para acumular riquezas tendo como base a exploração da classe trabalhadora, provoca uma "nova morfologia do trabalho”, que, de acordo com Antunes (2009), intensifica-o pela 
exigência de mais energia dos trabalhadores e trabalhadoras no desempenho de suas atividades laborais e precariza suas condições de realização.

Sobre a mencionada intensidade, esta pesquisa procurou aproximar-se do movimento que o componente recursos humanos realiza nas condições de trabalho da assistência social no Distrito Federal, e evidenciou alguns elementos com os quais o objeto se relaciona, sem, contudo, ter a pretensão de esgotar as reflexões atinentes a esse objeto.

Dal Rosso (2008, p. 28-29) afirma que essa intensidade pode ser percebida quando, na prática, há “uma exigência de maior esforço dos trabalhadores nas condições contemporâneas”, aumentando a produtividade em um mesmo período de tempo considerado. Para esse autor, há de se observar, ainda, o grau de intensificação do trabalho influenciado pelas transformações tecnológicas e pela reorganização laboral, o que se reflete em si e na precarização de suas condições.

Nesta pesquisa, considera-se a hipótese de que o componente recursos humanos (nas condições de trabalho do Suas, que vem sendo atacado pela reestruturação produtiva e pela ideologia neoliberal) sofre intensificação do trabalho em virtude do quadro reduzido de trabalhadores ${ }^{1}$ que executam suas atribuições, de forma desproporcional ao aumento da demanda de atendimento, resultado diretamente proporcional do crescimento, ampliação e aprofundamento da crise capitalista no Brasil.

Desse modo, o presente texto resulta de pesquisa que objetivou analisar as condições de trabalho no Suas, no Distrito Federal, considerando o componente recursos humanos e as relações com os elementos que o constituem, ou seja:

a) Vínculo empregatício: identificar tipos de vínculos empregatícios presentes em unidades dos Centros de Referência de Assistência Social (Cras) e Centros de Referência Especializado de Assistência Social (Creas).

1 A utilização da palavra trabalhadores, neste texto, compreende os trabalhadores, sejam eles homens ou mulheres, que mediam direitos socioassistenciais no Suas. 
b) Número de servidores: identificar o número de cargos vagos e cargos ocupados e relacioná-los com o número de servidores da equipe de referência estipulado para cada nível de proteção social, de acordo com a Norma Operacional Básica de Recursos Humanos do Suas - NOB-RH/Suas/2006 (BRASIL, 2011).

c) Remuneração: analisar se a remuneração dos trabalhadores atende às necessidades humanas básicas.

d) Intensificação do trabalho: investigar a possibilidade de estar ocorrendo intensificação do trabalho, relacionando os recursos tecnológicos, a demanda de atendimento, a carga horária e o número de servidores.

e) Educação permanente: observar se o plano de carreira, cargos e salários valoriza a política de educação voltada para o trabalho e a qualificação profissional continuada.

É importante dizer que no Brasil, desde o início dos anos 1990, o mundo do trabalho tem sido profundamente afetado pela reestruturação produtiva provocada pelas ofensivas do capital para a acumulação de riqueza, o que, por conseguinte, influencia a organização dos indivíduos sociais - homens e mulheres - baseada em seus trabalhos na sociedade (ALVES, 2005; RAICHELLIS, 2011), o que justifica a necessidade de investigação sobre o tema.

A interlocução com os sujeitos que protagonizam o mundo do trabalho na política de assistência social foi de suma importância para compreender a questão para além do imediatismo que se apresenta em observações espontâneas do senso comum. Entende-se, a partir da opção teórico-metodológica do materialismo histórico, que é preciso aproximar-se dialeticamente da essência do fenômeno que ora se esconde, ora se apresenta no seu "claro-escuro" no cotidiano do trabalho (KOSIK, 1976, p. 15).

De fato, analisar as condições de trabalho dos trabalhadores do Suas no Distrito Federal é revelar como se concretiza um dos principais motivos da luta da classe trabalhadora em suas reivindicações históricas 
no enfrentamento da questão social, ${ }^{2}$ pois, segundo Raichellis (2011), a organização do trabalho e, nela, as condições de trabalho, são incisivamente afetadas na sociedade capitalista contemporânea pelo processo de reestruturação produtiva.

Sobre a metodologia, a análise objetivou perceber o movimento dinâmico do objeto à luz do método histórico-dialético, procurando desvendar sua essência pela aproximação “da coisa em si”, para além das expressões imediatas, pois a aparência "indica a essência e, ao mesmo tempo a esconde no seu claro-escuro" (KOSIK, 1976, p. 15). Daí a necessidade de um método que revele a essência nas suas formas de ser.

A pesquisa teve natureza qualitativa, a qual, segundo Minayo (2010, p. 21), "trabalha com o universo dos significados, dos motivos, das aspirações, das crenças, dos valores e das atitudes” que não podem ser contabilizados quantitativamente, mas que têm significância no bojo das reflexões em pauta e, ao mesmo tempo, oferecem dados quantitativos importantes para efetuar a operação de triangulação - quando se cerca o objeto de pesquisa de variadas técnicas de investigação, a fim de obter maior aproximação com suas diferentes dimensões. A pesquisa foi composta pelas seguintes etapas: fase exploratória, trabalho de campo e análise e tratamento do material documental.

Com vistas a compreender o objeto do presente estudo, realizou-se, na fase exploratória, o levantamento do material bibliográfico e documental. Foram instrumentalizadas, nessa fase inicial, a Constituição Federal de 1988, a Política Nacional de Assistência Social (PNAS), a

2 Para Iamamoto (2001), a questão social diz respeito ao conjunto das expressões das desigualdades sociais engendradas na sociedade capitalista. Sua gênese está no caráter coletivo da produção, do qual não deve ser dissociada, pois é neste que as desigualdades se acirram. Há uma desproporção entre o crescimento da acumulação capitalista e o aumento do contingente de trabalhadores aptos para o trabalho, sendo este muito superior, embora desprovido não só dos meios de produção como dos direitos do mundo do trabalho, o que provoca disparidades econômicas, políticas e culturais entre as classes sociais. Assim, para a autora, Marx compreendeu a dinâmica da questão social determinada pela lei geral de acumulação capitalista, ao que acrescenta que a origem da questão social é imanente à organização social do capital, sem a qual não deve ser analisada. 
Lei Orgânica da Assistência Social (Loas 2012), a NOB/Suas (2005), a NOB-RH/Suas (2006), os Censos Suas (2016 e 2017), os Planos Decenais da Assistência Social (2006-2015 e 2016-2026) e as resoluções das Conferências Nacionais de Assistência Social dos anos de 2003, 2011 e 2015, no intuito de correlacionar as suas deliberações e as ações efetivadas.

Esse acervo bibliográfico e documental possibilitou a reconstrução histórica da assistência social, a fim de estabelecer a aproximação necessária com sua historicidade e seus determinantes, posto que estes influenciaram e influenciam as relações, as condições e os processos de trabalho, afetando sua configuração.

Foram utilizadas informações solicitadas à Secretaria Adjunta de Desenvolvimento Social do Distrito Federal (Seads) ${ }^{3}$ acerca das unidades pesquisadas, o que possibilitou dar direção ao trabalho de campo. A partir desses dados, foi possível conhecer o número de unidades públicas da Proteção Social Básica e da Proteção Social Especial de média complexidade, respectivamente, Cras e Creas, nos quais foi desenvolvido o trabalho de campo.

A cooperação da Seads no sentido de fornecer informações acerca das unidades, das suas demandas de atendimento, dos trabalhadores e dos seus vínculos empregatícios, entre outras informações, e os dados dos últimos Censos Suas (2016, 2017) trouxeram significativas informações sobre as condições de trabalho na execução dessa política social pública.

Os critérios para a escolha da amostra da pesquisa, no que se refere à Proteção Social Básica, tiveram como referência os equipamentos Cras instalados nos territórios em situação de maior e menor vulnerabilidade econômica ${ }^{4}$ por Região Administrativa do Distrito Federal, apurados na Pesquisa

3 O Decreto $n^{\circ} 39.610$, de $1^{\circ}$ de janeiro de 2019, alterou o nome do órgão para Secretaria de Desenvolvimento Social.

4 De acordo com a Pesquisa Distrital por Amostra de Domicílio (PDAD 2015), realizada pela Companhia de Planejamento do Distrito Federal (Codeplan), domicílios em situação de vulnerabilidade econômica são aqueles que têm renda de até um quarto de salário mínimo que, em 2015, era de R \$ 788,00, ou seja, R \$ 197,00. 
Distrital por Amostra de Domicílios (PDAD 2015), ou seja: escolheram-se equipamentos situados em territórios com condições econômicas opostas - um que fosse de uma região com fortes indicadores sociais de pobreza e vulnerabilidade social ${ }^{5}$ e outro situado em uma região menos vulnerável. Assim, compuseram a amostra da pesquisa os Cras situados em Brasília e em Ceilândia Norte. Para os Creas, o recorte compreendeu os referenciados por cada um desses Cras, sendo eles o Creas Brasília e o Creas Ceilândia, os quais foram escolhidos pelo mesmo critério adotado para os Cras. ${ }^{6}$

A técnica da entrevista não diretiva, que consiste em motivar a fala do participante com indagações e deixá-lo livre para expressar-se, teve o objetivo de promover o diálogo a partir de perguntas iniciais, acreditando-se que "não é possível realizar entrevista não diretiva na base da intuição, nem do bom senso, do tato ou da típica ingenuidade das entrevistas comuns” (THIOLLENT, 1987, p. 81).

\section{Considerações sobre as unidades dos Centros de Referência de Assistência Social (Cras) e dos Centros de Referência Especializado de Assistência Social (Creas)}

Partindo da observação da intensidade do trabalho no Brasil, e considerando a particularidade dos trabalhadores e das trabalhadoras da assistência social brasileira como classe trabalhadora que resiste às diversas formas de opressões e explorações impostas pelo Estado capitalista, alguns indicadores apurados nos Censos Suas anuais revelam indícios de que os trabalhadores dessa política têm seus vínculos empregatícios abalados pelas fragilidades que ali se encontram.

5 Em consonância com a Política Nacional de Assistência Social - PNAS (2004), a vulnerabilidade social decorre da pobreza, da privação ou ausência de renda e da fragilização dos vínculos afetivos.

${ }^{6}$ A realização da pesquisa teve o parecer favorável do Comitê de Ética em Pesquisa do Instituto de Ciências Humanas e Sociais da Universidade de Brasília (CEP/CHS/UnB), de acordo com a Resolução ${ }^{0}$ 466, de 12 de dezembro de 2012, que dispõe sobre as diretrizes e normas regulamentadoras de pesquisas que envolvem seres humanos, incluindo a apresentação do Termo de Consentimento Livre e Esclarecido (TCLE). 
O Censo Suas ${ }^{7}$ de 2016 (BRASIL, 2017b), por exemplo, revelou que existem em todo o Brasil 8.240 Centros de Referência de Assistência Social (Cras). Esse Censo, que teve sua coleta realizada entre 12 de setembro e 4 de novembro de 2016 e contou com a participação de 89.038 trabalhadores das Unidades Federativas (UF) de todo o país, revelou que existem no território nacional 8.240 Cras.

No Distrito Federal existiam 27 Cras, nos quais foram contabilizados 395 (0,4\% do total) trabalhadores, distribuídos conforme os seguintes vínculos empregatícios: 387 servidores estatutários; dois empregados públicos; quatro comissionados; e dois pertencentes a outros vínculos, não especificados (BRASIL, 2017b).

O Cras é uma unidade pública da Política Nacional de Assistência Social pertencente ao nível de Proteção Social Básica (PSB), na qual são atendidas famílias em situação de vulnerabilidade e risco de rompimento dos vínculos familiares e/ou comunitários, funcionando também como porta de entrada para que as pessoas que tiveram seus direitos violados sejam encaminhadas à proteção social especial. A unidade oferece o Serviço de Proteção Especializado Integral à Família (Paif), a Abordagem Social e o Serviço de Medidas Socioeducativas em Meio-Aberto e o Serviço de Convivência e Fortalecimento de Vínculos (SCFV), além de oficinas e outras atividades pertinentes à dinâmica comunitária do território (BRASIL, 2017b).

No ano de 2017, o Censo Suas (BRASIL, 2017c) computou 356 registros de trabalhadores nos 27 Cras do Distrito Federal, assim distribuídos em suas estatísticas sobre os vínculos empregatícios: 345 servidores estatutários; dois empregados públicos; um com outro vínculo empregatício não permanente; um servidor temporário e sete comissionados, lotados em Cras urbanos e periféricos - que são aqueles localizados nas zonas rurais. Segundo o Censo Suas (2017), o Brasil possui

7 Realizado anualmente pela Secretaria de Avaliação e Gestão da Informação (Sagi) e pela Secretaria Nacional de Assistência Social (SNAS) para acompanhar a estruturação do Suas no país. 
8.336 Cras, dos quais 8.292 finalizaram o preenchimento do questionário, o que corresponde a 99,47\% do total.

Por sua vez, o Creas é uma unidade pública da Política de Assistência Social. Seu âmbito de atuação é a Proteção Social Especial (PSE), "modalidade de atendimento assistencial destinada a famílias e indivíduos que se encontram em situação de risco pessoal e social" (CNAS, 2004). A unidade oferece o Serviço de Proteção e Atendimento Especializado a Famílias e Indivíduos (Paefi) e a Abordagem Social e o Serviço de Medidas Socioeducativas em Meio Aberto, podendo ofertar outros serviços complementares (BRASIL, [2017a]).

Sobre o Creas, o Censo Suas (2016) revelou que havia dez unidades no Distrito Federal e um total de 22.680 trabalhadores distribuídos pelo país. Porém, os dados não revelaram os vínculos empregatícios e o número de trabalhadores por UF, e sim por região. Sobre as modalidades empregatícias, constataram-se os mesmos tipos de vínculos existentes entre os trabalhadores dos Cras: servidores estatutários, empregados públicos e comissionados, entre outros.

De todos os Creas existentes no país, 2.546 (98,99\%) finalizaram o preenchimento do questionário dos Censos apontados na presente pesquisa. No que diz respeito às estruturas físicas dos equipamentos, percebe-se que parte deles funciona em imóveis próprios, outra parte em propriedades alugadas ou cedidas e também em espaços compartilhados. Em alguns casos, as estruturas físicas apresentam acessibilidade para pessoas com deficiência; em outros, não.

Sobre os imóveis ocupados pelos Cras, o Censo Suas (2017) apontou que $52,7 \%$ estão instalados em imóveis próprios da prefeitura municipal, 36,9\% em imóveis alugados pela prefeitura municipal e 10,4\% em imóveis cedidos à prefeitura local. Para os Creas, o Censo Suas (2017) apurou que 28,4\% estão situados em imóveis próprios, 63,0\% em imóveis alugados e 8,6\% em imóveis cedidos.

Nos dois tipos de unidades - Cras e Creas - é possível observar que o Suas ainda se encontra em um processo de implementação e que o investimento em recursos humanos, estrutura física, formação e educação permanente (que inclua cursos de pós-graduação), além 
da rotatividade nas equipes de gestores para oportunizar experiências diversificadas aos profissionais, são fundamentais para a melhoria das condições de trabalho, já que a precarização dos vínculos e de outros elementos que deveriam estruturar o Suas ainda persistem.

Em acréscimo aos dados quantitativos apresentados, é importante conhecer o universo cotidiano dos trabalhadores inseridos nas unidades do Suas, com o propósito de ir além das representações imediatas desses dados, os quais revelam uma parte da realidade, mas também ocultam aspectos essenciais que estão contidos na dinamicidade e contraditoriedade do real, considerando suas múltiplas e complexas determinações.

\section{Condições de trabalho no Suas sob a ótica dos trabalhadores}

Ao abordar as condições de trabalho no Suas do DF, nada poderia ser mais significativo que ouvir as representações, as emoções, as percepções e os anseios de trabalhadores e trabalhadoras, na tarefa imprescindível de discorrer sobre seu cotidiano de trabalho.

A leitura de mundo dos trabalhadores legitima a natureza qualitativa da pesquisa, uma vez que os recursos humanos são parte fundamental das condições de trabalho. Nesse sentido, o diálogo produzido com os protagonistas dessa política, sem ignorar a teoria que a embasa e fundamenta, é ato intrinsecamente político e libertador.

Como de maneira alguma poderia deixar de ser, a reflexão que se segue sobre esse objeto dinâmico é influenciada por seus determinantes político-econômicos e é revelada pela leitura de mundo de quem vivencia os pormenores do objeto e contribui para a construção, junto com ele, da história da assistência social brasileira.

A pesquisa anual representada pelos Censos Suas, apesar de ter sua legitimidade, não desvela completamente, tal como os relatos qualitativos, as dimensões da cotidianidade de quem vivencia o trabalho no âmbito da assistência social no Distrito Federal.

O olhar sobre o grupo analisado abarca trabalhadores que atuam no atendimento aos usuários sem considerar especificamente o cargo 
para o qual tomaram posse ou a sua escolaridade, posto que todos e todas que estão inseridos(as) na categoria mais ampla de trabalhadores vivenciam igualmente, enquanto servidores do Suas, as consequências das contrarreformas trabalhistas.

No sentido das transformações oriundas da contrarreforma trabalhista, que retira direitos dos trabalhadores, alinham-se a política de baixos investimentos estatais e a falta de condições de trabalho que assegurem qualidade à mediação dos serviços socioassistenciais, fatores que impactam nas relações de trabalho concretamente vividas em cada unidade.

Mesmo sabendo que esta investigação não abarca a totalidade das referidas condições de trabalho, os esforços da pesquisa concentraram-se em assegurar, dentro da seleção feita, que os entrevistados discorressem o máximo possível sobre o cotidiano de trabalho, com o objetivo de possibilitar "um meio de aprofundamento qualitativo da investigação” (THIOLLENT, 1987, p. 80).

Considerando a natureza qualitativa da pesquisa, atentou-se para o significado do que se fala e para as implicações que cada elemento das condições de trabalho teve nas relações de trabalho e na vida profissional dos participantes.

A escolha dos entrevistados aconteceu de forma aleatória, em cada unidade selecionada, de duas maneiras: por contato telefônico, por meio do qual a pesquisa foi explicitada, ou por contato direto nas unidades dos Cras e Creas, onde, do mesmo modo, a pesquisa também foi descrita; posteriormente, solicitou-se a participação voluntária dos servidores e servidoras.

Todas as entrevistas aconteceram nas quatro unidades selecionadas: Cras Ceilândia Norte, Cras Brasília, Creas Ceilândia Norte e Creas Brasília, em local reservado para resguardar, com sigilo, as informações prestadas. As falas foram gravadas e, no início de cada entrevista, apresentaram-se aos participantes os seguintes documentos: carta de aceite da Secretaria de Desenvolvimento Social; Termo de Consentimento Livre e Esclarecido (TCLE); e a Resolução nº 466 do Comitê de Ética em Pesquisa do Instituto de Ciências Humanas e Sociais da 
Universidade de Brasília (CEP/CHS/UnB), com o respectivo parecer favorável à realização da investigação.

Foi elaborado um quadro a partir das informações obtidas na pesquisa de campo, a seguir.

Quadro 1: Perfil dos entrevistados

\begin{tabular}{|l|l|l|l|l|l|l|}
\hline Nome & Sexo & $\begin{array}{l}\text { Tempo de } \\
\text { trabalho na } \\
\text { instituição }\end{array}$ & Escolaridade & $\begin{array}{l}\text { Vínculo } \\
\text { empregatício }\end{array}$ & Cargo & Carga horária \\
semanal
\end{tabular}

Fonte: Elaboração própria.

\subsection{Perfil dos entrevistados}

A partir da análise dos dados, constata-se que, entre os entrevistados, o vínculo empregatício preponderante é o estatutário, com ingresso pela via de concurso público para cargo efetivo, exceto por um voluntário.

8 Para preservar o sigilo e a identidade dos sujeitos, foi resguardado o cargo ocupado pelos entrevistados e se atribuíram nomes fictícios a cada participante. 
A maioria dos servidores está na carreira pública de assistência social há aproximadamente dez anos. Por coincidência, foi notável a margem de seis a dez anos de trabalho, exceto por três servidoras: duas mais antigas, que trabalham há mais de dez anos na instituição, e uma servidora que está há cerca de quatro a seis anos na secretaria.

A escolaridade predominante dos participantes é o nível superior com pós-graduação, independentemente do cargo que ocupam e do tempo de serviço na instituição. A seleção, como dito, foi aleatória; porém, entre as unidades pesquisadas, foi visível uma expressiva presença feminina, fato que se reflete na composição da seleção realizada e que está em consonância com indicadores do Censo Suas (2017), o qual apontou um contingente de 80,5\% de trabalhadoras mulheres em contraposição a 19,5\% de trabalhadores homens no país.

\subsection{Condições físicas e materiais de trabalho}

Percebeu-se que muitos dos entrevistados expressam descontentamento com a estrutura física da unidade em que trabalham e com a falta de adequação e disponibilidade de recursos materiais, independentemente do tempo de serviço. Quando indagados sobre o assunto, as falas dos respondentes convergiram, em sua maioria, para a inadequação de recursos materiais e de estrutura:

Na nossa estrutura, não tem sala de atendimento para você atender de forma individualizada. A sala de atendimento coletivo e de reuniões é a mesma. A estrutura em si não é adequada. Quem estiver na sala ao lado pode ouvir o atendimento, e isso é bem complicado. É uma sala só. A brinquedoteca não é adequada e, às vezes, a gente faz o atendimento de adultos na própria brinquedoteca porque não tem onde atender. Tem período de calor que é tão quente que você não aguenta. Então, já teve pessoa que falou: “Olha, eu não quero mais o atendimento porque eu não aguento ficar nessa sala. Eu vou sair... Eu não dou conta de ficar nessa sala porque está muito quente.” A internet não funciona e a gente precisa de internet para acessar o sistema, o prontuário. 
Às vezes, eu vou atender uma pessoa e não consigo ver os atendimentos anteriores dela, eu não consigo registrar. A internet não é boa. (Aline)

A partir das entrevistas realizadas com os servidores, observa-se que há expressões significativas sobre as condições físicas das unidades: salas pequenas, inapropriadas para o atendimento sigiloso, ${ }^{9} \mathrm{com}$ pouca ventilação e inadequação de equipamentos. Essas expressões são comuns nas falas, independentemente de a unidade pertencer à PSB ou à PSE. Por outro lado, alguns não demonstram inquietação quanto à falta de recursos como canetas, papéis e outros materiais de escritório e de uso contínuo. A Tipificação Nacional de Serviços Socioassistenciais (BRASIL, 2009) dispõe sobre os serviços que são de responsabilidade da execução do nível da PSB e da PSE. Esse documento, além de especificar os serviços de cada nível de proteção social, estipula quais provisões devem ser atendidas para a qualidade na prestação dos serviços e quais aquisições devem ser possibilitadas aos usuários.

Para os Cras, a fim de que sejam ofertados os serviços de Paif e SCFV em domicílio para idosos e pessoas com deficiência, as devidas provisões, de acordo com a Tipificação Nacional, envolvem ambiente físico, recursos materiais, materiais socioeducativos, recursos humanos e trabalho social essencial ao serviço. Entre tantas recomendações, evidencia-se o que explicita a Tipificação para o ambiente físico:

Espaços destinados para recepção, sala(s) de atendimento individualizado, sala(s) de atividades coletivas e comunitárias, sala para atividades administrativas, instalações sanitárias, com adequada iluminação, ventilação, conservação, privacidade, insalubridade, limpeza

9 Investigadores da saúde do trabalhador, como Franco, Druck e Seligmann-Silva (2010) são taxativos ao afirmar que as práticas nas quais o trabalhador enfrenta imposições que dificultam o exercício da ética profissional favorecem o adoecimento. Para o Serviço Social, há legislação específica que regulamenta a exigibilidade do sigilo profissional, como o Parecer do CFESS no 06/13 (CFESS, 2013) e o Código de Ética Profissional do Serviço Social (CFESS, 1986). 
e acessibilidade em todos os seus ambientes, de acordo com as normas da ABNT. O ambiente deve possuir outras características de acordo com a regulação específica do serviço e do Centro de Referência de Assistência Social. (BRASIL, 2009, p. 13).

Pelas expressões nas falas dos servidores entrevistados, responsáveis pela execução dos serviços descritos, as condições vivenciadas nas unidades não seguem o disposto nessa Tipificação. Entre algumas falas mais descontentes com as provisões estão a de Carla e de Deise. A fala de Carla, embora tenha verbalizado que a "unidade está bem assistida”, revelou a necessidade de mais computadores e de outros equipamentos na área de atendimento. Deise, apesar de afirmar que os materiais pedagógicos são satisfatórios para o trabalho com os grupos, deixou claro o envolvimento financeiro dos servidores para dinamizar os trabalhos. Na expressão da servidora,

Um lanche especial que precisa ser entregue para uma confraternização com as famílias, geralmente, a gente traz. Nos dois últimos grupos que fizemos aqui, nós precisamos tirar cópia colorida para trabalhar um álbum com as famílias, e tudo isso foi feito por fora, com o objetivo de deixar o trabalho mais dinâmico. (Deise)

No entanto, houve muito descontentamento nas percepções de outros partícipes sobre seus cotidianos de trabalho, dados os elementos disponíveis no ambiente. Quanto a esse aspecto, Aline não hesitou nas palavras ao mencionar com ênfase: "Adequado não, não é adequado.” A mesma insatisfação foi observada nas falas de Bianca sobre a exposição no atendimento, que deveria ser privado: "A gente não tem um espaço adequado de atendimento”, o que foi reforçado por Elvira: "A iluminação atende às necessidades da unidade, mas a ventilação é inadequada”. O mesmo se repetiu com Gustavo e foi confirmado por Higor em seus depoimentos.

Sublinha-se que o resguardo da privacidade dos usuários é parte integrante dos princípios ético-profissionais dos trabalhadores do Suas 
e que os trabalhadores, na defesa dos direitos de sigilo da história de vida e vulnerabilidades dos usuários, estão exercendo "a defesa intransigente dos direitos socioassistenciais” (BRASIL, 2011).

Ressalta-se que, além de caracterizar as provisões necessárias à prestação dos serviços socioassistenciais, a Tipificação Nacional também estabelece as aquisições dos usuários e pontua que, para ser assegurada a acolhida, deve-se garantir a privacidade do atendido (BRASIL, 2009).

No conjunto das falas, mesmo entre tantos descontentamentos com a inadequação das estruturas físicas das unidades pesquisadas nesse universo selecionado, houve, como diferencial, a percepção de que existe um equipamento de assistência social que se sobressaiu pelas condições de trabalho apresentadas, sendo ele o Creas Ceilândia.

Ainda que nesta investigação não seja possível relacionar todos os componentes das condições de trabalho das quatro unidades selecionadas, é imprescindível salientar a referida unidade, que se revelou um expoente importante e merecedor de destaque. No equipamento citado, nota-se, sem o menor esforço, que o ambiente é bastante agradável, com salas adequadas para o atendimento individualizado e coletivo, iluminação satisfatória, organização, higiene e amplitude de espaços, que chegam a atender completamente, ou quase completamente, às provisões da Tipificação Nacional para Serviços Socioassistenciais (BRASIL, 2009).

\subsection{Equipes multiprofissionais}

A NOB-RH/Suas/2006 orienta que os equipamentos Cras situados no DF, de acordo com o número de habitantes do território e o nível de gestão em que se enquadram (inicial, básica e plena), devem ter suas equipes de referência compostas por “[...] técnicos de nível superior, sendo dois profissionais assistentes sociais, um psicólogo e um profissional que compõe o SUAS” (BRASIL, 2011, p. 30). Esse documento também recomenda que o conselho profissional possa fiscalizar as condições de trabalho dos trabalhadores que compõem a equipe multiprofissional.

Para os Creas, o mesmo documento orienta que, para a capacidade de atendimento de 80 pessoas/indivíduos, a equipe deve ser composta 
por um coordenador, dois assistentes sociais, dois psicólogos, um advogado e dois auxiliares administrativos. Todavia, os Cras e Creas pesquisados $^{10}$ encontram-se em inobservância da norma vigente, pois as equipes de referência não estão compostas de acordo com as orientações, conforme se pôde colher dos depoimentos dos entrevistados.

A Resolução n 17, de 20 de junho de 2011 (CNAS, 2011), aprovou as categorias profissionais de nível superior que compõem obrigatoriamente as equipes de referência: assistentes sociais e psicólogos para a PSB e assistentes sociais, psicólogos e advogados para a PSE de média complexidade. O mesmo documento resolveu que outras categorias poderão compor as equipes de referência, sendo preferencialmente: antropólogos, economistas domésticos, pedagogos e sociólogos.

A defasagem de recursos humanos repetiu-se nas unidades pesquisadas, e notou-se, de acordo com as falas dos servidores, que as atuais equipes de referência sofrem com a insuficiência de trabalhadores para garantir o atendimento de qualidade aos usuários, o que ficou evidente no incômodo revelado em seus depoimentos:

Se um servidor está de atestado médico, isso já sobrecarrega quem fica. Se um servidor tira licença, a gente não pode fazer uma série de coisas [...], é só um servidor para 14 áreas de atendimento e para as demandas espontâneas, demandas da unidade e demandas do agendamento do telefone 156, sem contar auditoria e demanda das assistentes sociais que vão fazendo atendimento. Hoje, por exemplo, só tem duas servidoras. (Fabíola)

Tem unidades que têm muitas demandas esperando atendimento. A gente tem cem, é só um exemplo. Então, não está bom, de qualquer jeito, não está! Mas em relação a outras áreas, a gente, especialista, acaba entrando em outro tipo de atendimento. Às vezes, não tem servidor para fazer um atendimento inicial, fazer a recepção, abrir prontuário. Eu, aqui, faço Cadastro Único. Não tem motorista, eu vou, dirijo, levo usuário para fazer

${ }^{10}$ Não foi disponibilizado o quadro das equipes de referência de todas as unidades, embora este tenha sido solicitado mais de uma vez. 
acolhimento. Vou fazer visita com o meu carro ou com o carro da unidade, porque não tem motorista para fazer. Então, você acaba fazendo outras coisas que são de outras funções por não ter o servidor aqui. (Gustavo)

Não! A gente atende mais de 5 mil famílias e tem uma equipe muito reduzida. No total, nós temos poucos servidores. Muitos de atestado, uma para aposentar e outros adoecendo. A equipe fica bem sobrecarregada. À tarde, a gente não faz atendimento a não ser que seja funeral, aí eu venho para fazer, porque só tem uma pessoa de 30 horas de manhã, a outra está de férias. Na equipe técnica, tem esse problema, mas sempre que as servidoras estão juntas elas tentam resolver o problema. Agora tem duas de atestado e uma de férias. Elas pegam os casos mais graves da espontânea e tentam resolver. (Higor)

O descompasso entre cargos vagos e o quantitativo de cargos existentes marca explicitamente a escassez de recursos humanos na Política Pública de Assistência Social do Distrito Federal, como demonstra o Portal da Transparência com referência ao mês de julho de 2018.

Na consulta ao site, o cargo de auxiliar em assistência social indicava 500 vagas, das quais 281 estavam ocupadas. Para o cargo de técnico em assistência social, constavam 3.000 vagas, porém apenas 650 estavam ocupadas. O cargo de especialista em assistência social tinha 2.000 vagas, sendo que estavam ocupadas somente 456 (DISTRITO FEDERAL, [2018]).

Os trabalhadores e as trabalhadoras que participaram desse percurso investigativo relacionaram a insuficiência dos recursos humanos ao esforço no desempenho de suas atribuições, somado ao de suprir também as funções de outros cargos no cotidiano de trabalho. O exercício contínuo de muitas atribuições diariamente, para além das suas específicas, é prática comum que foi percebida nas falas dos entrevistados, conforme se pode observar a seguir:

Não adianta ter só um psicólogo, só um educador. Existe isso na Secretaria, o que para mim é mais uma escolha política. Não tem profissional suficiente, então 
todo mundo faz tudo e todo mundo faz a mesma coisa. E mesmo assim, hoje, a gente não dá conta de atender toda a demanda. A gente atende uma região extensa e outros serviços como trabalho infantil, situação de rua... A demanda é muito extensa e esse Creas é considerado um dos maiores. Por falta de profissional, eu tive que fazer várias coisas ao mesmo tempo. Aqui é muita sobrecarga. Muito atendimento. É demanda de promotoria, demanda da população, e isso foi me frustrando. Não tem carro para levar a gente. Aliás, aqui tudo a gente faz muito além: liga do nosso telefone pessoal, vai no nosso próprio carro para resolver problema da unidade. E essa sobrecarga de trabalho extrapolou: eu tive afastamento psiquiátrico. Eu tive crise de ansiedade e comecei a perceber que eu podia desenvolver síndrome do pânico. (Aline)

Na fala de Aline, constata-se a ausência de outras especialidades para compor a equipe que deveria ser multiprofissional, conforme orientado na Tipificação Nacional, em categorias profissionais obrigatórias e categorias profissionais preferenciais. A pluralidade de formações acadêmicas da equipe de referência confere a possibilidade de vários olhares para o atendimento das demandas. Do contrário, a equipe reduzida, além de afetar a qualidade do serviço prestado, provoca o excesso de trabalho, como relatado pela trabalhadora: “Aqui, é muita sobrecarga. Muito atendimento.”

Carla, por exemplo, usou a palavra "desdobrar", como sinônimo de dispêndio de forças para além de suas atribuições a fim de conseguir realizar a quantidade de atendimentos necessários, de acordo com a demanda do território: “Às vezes, casos que precisam ser atendidos com certa urgência não conseguem ser atendidos porque não tem como se desdobrar mais. Eles procuram atender o máximo que podem” (Carla).

Em outros diálogos, revelou-se que o desempenho das atribuições de outros cargos, ou do mesmo cargo em acúmulo, por falta de servidor, é comum e provoca demasiado esforço ao ser realizado paralelamente. Algumas falas convergem nesse sentido, como os depoimentos que seguem: 
As pessoas fazem várias atribuições ao mesmo tempo, para tentar suprir o que é necessário. Mesmo assim, a gente não tem conseguido. Eu creio que a gente tem essa sensação com frequência: que estamos indo além do que a gente deveria fazer. (Bianca)

Eu consigo perceber que é muito esforço para fazer tudo que é de responsabilidade do meu cargo e de outro. (Deise)

A ausência de concurso há mais de dez anos obriga todos aqui a assumir mais um pouco, e isso é gradativo. Uma pessoa se aposentou, uma pessoa está de licença, a falta de motorista, a falta de um outro colega. Sempre! Quando falta alguém, o outro fica sobrecarregado, sempre! (Elvira)

A gente vai se virando e muitas vezes você acaba fazendo coisas que não são da sua atribuição, mas não há quem faça e você acaba tendo que fazer. (Gustavo)

Quando a pessoa que está de férias voltar, vai sobrecarregá-la como nos outros anos. Quando as outras pessoas estão de férias, ela fica com a demanda dela e com as das outras. $E$ isso a gente vê que está causando adoecimento. Ela agora está indo com mais frequência ao médico. (Higor)

Essas falas realçam que o desempenho das atribuições, de maneira a requisitar do servidor esforço considerável, está intrinsecamente ligado ao baixo número de servidores ou mesmo à ausência deles para algumas funções específicas. Esse fato não é característica peculiar da capital do país. Para Silveira (2011, p. 23) "é possível identificar que a grande maioria dos estados apresenta um número insuficiente de técnicos em suas estruturas administrativas para o desempenho de suas funções [...]."

A superação da precariedade das equipes de trabalho no Suas é um desafio para a gestão do trabalho, no sentido de encontrar estratégias que reforcem as equipes de referência e que o façam sem precarizar os vínculos empregatícios dessa categoria de trabalhadores, o que constitui um esforço e resistência da assistência social, na constituição 
de equipes fortalecidas e qualificadas em um momento de ataque aos direitos do trabalho.

Ao mesmo tempo, os relatos aqui transcritos possibilitam ampliar as relações sobre o desempenho de muitas atribuições concomitantemente com o número alto de demandas, o baixo número de servidores e as dificuldades enfrentadas em relação aos recursos tecnológicos, o que estabeleceu correlação com a intensidade vivenciada por parte de cada trabalhador no desempenho de suas atribuições.

Para Raichelis (2011),

[a] intensificação, a partir dessa perspectiva, é mais do que esforço físico, envolve o conjunto de capacidades do trabalhador que mobilizam seu corpo, suas mentes, emoções e afetividade, os conhecimentos e os saberes adquiridos pela formação especializada e pela experiência acumulada, além das relações estabelecidas com outros sujeitos nos contextos do trabalho coletivo e cooperado, sem o que o próprio trabalho se tornaria irrealizável. (RAICHELIS, 2011, p. 53).

\subsection{Remuneração}

A remuneração foi um ponto de destaque na coleta de informações. Segundo as exposições dos entrevistados, esse elemento é um dos componentes das condições de trabalho que provoca muito desagrado. Sobre a satisfação quanto ao suprimento das necessidades básicas dos trabalhadores com a atual remuneração, as falas expressaram, de maneira considerável, prejuízos advindos do não pagamento da terceira parcela, ou a afirmação de que a remuneração é baixa pela responsabilidade exigida do cargo. Carla diz: "Eu tenho dois filhos e a gente vem sempre procurando dar o melhor para eles. Comprei minha casa com muito custo. Isso me onerou muito e eu contava com a terceira parcela para conseguir custear o pagamento da minha casa” (Carla).

A desvalorização do trabalho e o esforço despendido pelo trabalhador para além de suas atribuições refletem na execução da Política 
Nacional de Assistência Social e também no olhar que cada trabalhador tem sobre si mesmo. A autoimagem desprestigiada, forjada pelas intenções da classe dominante e pelo descrédito que atinge a toda a categoria profissional, reproduz os ataques e tensões de forças entre capital/trabalho, nos quais a remuneração é elemento imprescindível para medir a valorização do trabalho e dos trabalhadores, ao passo que os desprestigia.

A tensão das forças entre capital/trabalho tende a menosprezar os trabalhadores que, diante das consequências dos conflitos, veem-se no exercício minimizado da cidadania pela imposição dos interesses capitalistas sobre a classe trabalhadora - afinal, não nos esqueçamos, "a mais valia é a finalidade direta e o móvel determinante da produção” (MARX, 1985, p. 209).

Sobre o plano de carreira, cargos e salários, as falas dos entrevistados desvelaram descontentamento com a proporcionalidade da Gratificação de Titulação (GTIT), que, de acordo com o art. 25 da Lei 4.426, de 18 de novembro de 2009 (DISTRITO FEDERAL, 2009), tem como referência o valor de R \$ 2.800,00 para cada formação, variando seu percentual entre:

I - 30\% (trinta por cento), pela apresentação de título de Doutor;

II - 20\% (vinte por cento), pela apresentação de título de Mestre;

III - 15\% (quinze por cento), pela apresentação de diploma de curso de pós-graduação Lato sensu, com carga horária mínima de 360 (trezentos e sessenta) horas; IV - 10\% (dez por cento), pela apresentação de diploma de curso superior, para os ocupantes de cargos de nível médio e fundamental, ou de segunda graduação, no caso de ocupante de cargo de nível superior; $\mathrm{V}-7 \%$ (sete por cento), pela apresentação de certificado de conclusão de ensino médio ou habilitação legal equivalente, para os ocupantes de cargos de nível fundamental. (DISTRITO FEDERAL, 2009, p. 1).

Os percentuais das gratificações para cada nível de formação divergem da proposta dos servidores, pois não têm como referência o vencimento atual de cada cargo, e sim percentuais dedutíveis do valor de $\mathrm{R} \$ 2.800,00$. 
As motivações iniciais das entrevistas semiestruturadas possibilitaram o adensamento de diversos elementos que circundam as condições de trabalho. Entre eles, está a organização política dos trabalhadores, que foi de notável realce nas interlocuções. "Eu acho que existe uma mobilização política dos servidores por esse novo sindicato, com a ajuda desses novos servidores que vieram, com gás, com força” (Fabíola).

A participação política dos trabalhadores foi muito presente nas falas dos entrevistados, que exaltaram a organização sindical orientada pelo Sindicato dos Servidores da Assistência Social e Cultural do Governo do Distrito Federal (Sindsasc) como responsável pela ressignificação da categoria, entendendo que o órgão tem contribuído de forma significativa para um novo patamar de politização e mobilização coletiva.

O Sindsasc, no contexto de enfrentamentos, organizou com os servidores uma greve de 84 dias no primeiro semestre de 2018, e nos meses de agosto, setembro e outubro do mesmo ano, promoveu várias assembleias e paralisações, que reafirmaram a pauta de reivindicações pelo reajuste e por melhores condições de trabalho.

A realização desta pesquisa está embebida da apreensão do cotidiano, de cada entrevistado e entrevistada, sobre o contexto de suas condições de trabalho, consideradas as determinações sociais e históricas que envolvem o objeto de estudo. Foi, então, uma parcela da classe trabalhadora situada em um determinado espaço situacional - a política de assistência social no contexto do DF - com suas particularidades, e inserida nas relações gerais que envolvem a totalidade da classe trabalhadora, que falou por si, da qual o presente texto foi apenas instrumento de evidenciação de suas percepções.

\section{Considerações finais}

Tendo em vista que os fatos históricos são influenciados por determinantes estruturais, políticos e econômicos que os direcionam e os particularizam, na constituição histórica da política de assistência social como política pública de direitos de cidadania no Brasil, foram 
analisadas as condições de trabalho no Suas pela mediação do método crítico-dialético na sociabilidade do trabalhador.

Observaram-se na pesquisa contradições acerca da assistência social que são históricas e que se repetem na especificidade do Distrito Federal. Assim, percebem-se divergências entre a constituição das equipes de referência normatizadas pela NOB-RH/Suas/2006 (BRASIL, 2011) e a necessidade de mais trabalhadores no contexto do DF, pois as equipes são insuficientes para a oferta dos serviços socioassistenciais à população.

A contrarreforma trabalhista e a terceirização $0^{11}$ apontam para novas maneiras de precarizar as condições de trabalho e para retrocessos nas conquistas da classe trabalhadora. É o anúncio da austeridade na retirada de direitos trabalhistas na nova fase de precarização social do trabalho assalariado, que desprotege seus dependentes, tornando mais árdua a sobrevivência e a organização da vida pelo trabalho.

Dentre algumas das consequências da alteração do papel do Estado na gestão do trabalho para os trabalhadores do Suas, estão o incentivo à fragilização dos vínculos empregatícios que compõem os quadros das equipes de referência - marca histórica da assistência social - presentes nas unidades dos Cras e Creas pesquisadas, pela falta de compromisso do Estado em organizar, em tempo hábil, o quadro de servidores.

As falas dos participantes, voluntários desta investigação, foram muito marcantes no sentido da vivência da intensidade do trabalho e estabelecem relações com os recursos tecnológicos, uma vez que estes não colaboram para o bom desenvolvimento do trabalho, a exemplo da rede de internet,

${ }^{11}$ As consequências da retirada dos direitos dos trabalhadores pela contrarreforma trabalhista, além de aviltarem as conquistas elencadas na CLT (1943), incluindo férias, jornada de trabalho e salário mínimo, tão caras aos brasileiros, adentram para a esfera do acirramento da precarização da totalidade das condições de trabalho, ao passo que são articuladas por interesses adversos aos do trabalhador.

A decisão do plenário do Supremo Tribunal Federal (STF), que decidiu, no dia 30/08/2018, pela aprovação da terceirização irrestrita na administração pública, teceu laços mais estreitos com a fragilização de vínculos empregatícios estáveis. 
que é lenta, e dos computadores, que precisam ser atualizados. Esses dois recursos tiveram um notável destaque nas falas dos entrevistados.

Dessa maneira, há maior esforço no atendimento dos direitos socioassistenciais, tendo em vista o uso de recursos tecnológicos desatualizados, a falta de recomposição do quadro de servidores e o aumento do número de atendimentos na mesma jornada de trabalho. Correlaciona-se a tais variáveis que o desempenho de muitas atribuições no trabalho no Suas, nas unidades selecionadas, favorece um dispêndio de energias corporais, cognitivas e emocionais que o qualifica como trabalho intensivo.

Os vínculos empregatícios identificados são em sua maioria formais, com servidores concursados. No entanto, salienta-se que a seleção realizada abarcou parte do todo dos trabalhadores e que as análises das pesquisas dos Censos Suas evidenciam precarização dos vínculos empregatícios, em vista da presença de trabalhadores informais na composição das equipes de referência.

A remuneração dos servidores está prejudicada pelo descumprimento da Lei $n^{\circ}$ 5.184, de 25 de setembro de 2013, que dispõe sobre a Carreira Pública de Assistência Social no âmbito do Distrito Federal. A falta de compromisso do Poder Público com o pagamento da terceira parcela do reajuste provoca descontentamento na categoria, que percebe seu poder de investimento financeiro afetado no que concerne às necessidades básicas de moradia, alimentação, saúde e lazer.

É oportuno frisar que a totalidade das condições de trabalho ultrapassa a questão salarial. Porém, na sociedade capitalista baseada na compra e venda da força de trabalho em regime de assalariamento, esse quesito assume uma dimensão de centralidade.

Na observação das falas sobre a relação entre o plano de carreira, cargos e salários e a política de educação permanente, houve ênfase no valor de referência do qual se deduzem os percentuais para a gratificação de titulação e o adicional de qualificação, hoje estipulados segundo o valor de R \$2.800,00. Os valores das gratificações não são acumuláveis e divergem das propostas dos servidores, pois não têm como referência o vencimento atual. 
No entanto, assumiu relevância o destaque dado à estrutura e organização das condições de trabalho da unidade Creas Ceilândia, o que aponta para a necessidade de aprofundamento que desvele a essência de seu movimento diferencial em relação às outras unidades que foram parte da seleção deste estudo.

A conscientização política dos trabalhadores confirmou a importância da organização sindical como responsável pela ressignificação da categoria, o que tem contribuído para maior envolvimento e atuação nos enfrentamentos e lutas por melhores condições de trabalho. Essa dinâmica marca a resistência em assimilar a subalternidade como marca da sua cultura e lugar social.

A organização do trabalho, de acordo com as observações apreendidas na investigação, se dá à custa de muita carga emocional despendida para o cumprimento das atribuições voltadas à garantia dos direitos socioassistenciais. Os recursos humanos, componente primordial para a estruturação do Suas, encontram-se extenuados pelo desfalque de suas equipes de referência, e necessitam de espaço para construção de diálogo que problematize as suas condições de trabalho e fomente sua valorização.

\section{Referências}

ALVES, Giovanni. O novo (e precário) mundo do trabalho: reestruturação produtiva e crise do sindicalismo. São Paulo: Boitempo, 2005.

ANTUNES, Ricardo. Os Sentidos do Trabalho: ensaio sobre a afirmação e a negação do trabalho. 2. ed. 1. reimpr. São Paulo: Boitempo, 2009. BRASIL. Ministério do Desenvolvimento Social e Combate à Fome. Secretaria Nacional de Assistência Social. NOB-RH/SUAS: anotada e comentada. Brasília: Ministério do Desenvolvimento Social e Combate à Fome, 2011. 
BRASIL. Ministério do Desenvolvimento Social e Agrário. Secretaria Nacional de Assistência Social. Centro de Referência de Assistência Social (CREAS): Unidades de Atendimento. Brasília: Ministério do Desenvolvimento Social e Agrário, [2017a]. Disponível em: http:// mds.gov.br/assuntos/assistencia-social/unidades-de-atendimento/creas Acesso em: 29 maio 2017.

BRASIL. Ministério do Desenvolvimento Social e Combate à Fome. Secretaria Nacional de Assistência Social. Tipificação Nacional de Serviços Socioassistenciais. Brasília: Ministério do Desenvolvimento Social e Combate à Fome, 2009.

BRASIL. Ministério do Desenvolvimento Social. Secretaria Nacional de Assistência Social. Coordenação Geral de Vigilância Socioassistencial. Censo SUAS 2016: Bases e Resultados. Centros de Referência da Assistência Social - CRAS. Brasília: Ministério do Desenvolvimento Social, 2017b. Disponível em: http://aplicacoes.mds.gov.br/snas/ vigilancia/index2.php. Acesso em: 1 abr. 2017.

BRASIL. Ministério do Desenvolvimento Social. Secretaria Nacional de Assistência Social. Coordenação Geral de Vigilância Socioassistencial. Censo SUAS 2017: Bases e Resultados. Centros de Referência da Assistência Social - CRAS. Brasília: Ministério do Desenvolvimento Social, 2017c. Disponível em: http://aplicacoes.mds.gov.br/snas/ vigilancia/index2.php. Acesso em: 10 jun. 2018.

CONSELHO FEDERAL DO SERVIÇO SOCIAL (CFESS). Código de ética profissional do assistente social. Brasília: CFESS, 9 maio 1986. Disponível em: http://www.cfess.org.br/arquivos/CEP_1986.pdf. Acesso em: 22 maio 2020.

CONSELHO FEDERAL DO SERVIÇO SOCIAL (CFESS). Parecer Jurídico $n^{\circ} 06 / 13$. Uso de câmaras de filmagem instaladas em salas de atendimento do Serviço Social [...]. Brasília: CFESS, 18 abr. 2013. Disponível em: http://www.cress-es.org.br/site/images/parecer\%20jurdico\%20 cfess\%20n\%206-2013\%20sigilo.pdf. Acesso em: 10 maio 2018. 
CONSELHO NACIONAL DE ASSISTÊNCIA SOCIAL (CNAS). Resolução no 145 , de 15 de outubro de 2004. Aprova a Política Nacional de Assistência Social. Diário Oficial da União, Brasília, $n^{\circ}$ 208, Seção 1, p. 110, 28 out. 2004. Disponível em: https://www.legisweb.com.br/ legislacao/?id=101000. Acesso em: 5 maio 2018.

CONSELHO NACIONAL DE ASSISTÊNCIA SOCIAL (CNAS). Resolução $n^{\circ}$ 17, de 20 de junho de 2011. Ratificar a equipe de referência definida pela Norma Operacional Básica de Recursos Humanos do Sistema Único de Assistência Social - NOB-RH/SUAS e reconhecer as categorias profissionais de nível superior para atender as especificidades dos serviços socioassistenciais e das funções essenciais de gestão do Sistema Único de Assistência Social - SUAS. Diário Oficial da União, Brasília, n. 118, Seção 1, p. 79, 21 jun. 2011. Disponível em: https://conferencianacional.files.wordpress.com/2013/12/cnas-2011017-20-06-2011.pdf. Acesso em: 5 maio 2018.

DAL ROSSO, Sadi. Mais trabalho! A intensificação do labor na sociedade contemporânea. São Paulo: Boitempo, 2008.

DISTRITO FEDERAL. Lei n ${ }^{\circ}$ 4.426, de 18 de novembro de 2009. Reajusta as tabelas de vencimento das carreiras que menciona e dá outras providências. Diário Oficial do Distrito Federal, Brasília, n. 229, 27 nov. 2009. Disponível em: http://www.fazenda.df.gov.br/aplicacoes/ legislacao/legislacao/TelaSaidaDocumento.cfm?txtNumero=4426\&tx tAno=2009\&txtTipo=5\&txtParte=. Acesso em: 14 jun. 2018.

DISTRITO FEDERAL. Portal da Transparência. Servidores: cargo efetivo. Brasília: GDF, [2018]. Disponível em: http://www.transparencia. df.gov.br/\#/servidores/cargo-efetivo. Acesso em: 22 maio 2020.

DURIGUETTO, Maria Lúcia. Sociedade civil e democracia: um debate necessário. Libertas: Revista da Faculdade de Serviço Social, Juiz de Fora, v. 8, n. 2, p. 83-94, jul./dez. 2008. 
FRANCO, Tânia; DRUCK, Graça; SELIGMANN-SILVA, Edith. As novas relações de trabalho, o desgaste mental do trabalhador e os transtornos mentais no trabalho precarizado. Revista Brasileira de Saúde Ocupacional, São Paulo, v. 35, n. 122, p. 229-248, 2010. Disponível em: https://www.scielo.br/pdf/rbso/v35n122/a06v35n122.pdf. Acesso em: 19 maio 2020.

FREIRE, Paulo. A importância do ato de ler: em três artigos que se completam. 49. ed. São Paulo: Cortez, 2008.

IAMAMOTO, Marilda Vilela. A questão social no capitalismo. Revista Temporalis, Brasília, n. 3, jan./jun. 2001.

KOSIK, Karel. Dialética do concreto. 2. ed. Rio de Janeiro: Paz e Terra, 1976.

MARX, Karl. O Capital: crítica da economia política. Tradução: Regis Barbosa e Flávio R. Kothe. São Paulo: Abril Cultural, 1985.

MINAYO, Maria Cecília Souza (org.). Pesquisa social: teoria, método e criatividade. 34. ed. Petrópolis: Vozes, 2010.

PEREIRA-PEREIRA, Potyara Amazoneida. Política social: temas e questões. 2. ed. São Paulo: Cortez, 2009.

POULANTZAS, Nicos. Estado, o poder, o socialismo. Rio de Janeiro: Graal, 2000.

RAICHELIS, Raquel. O trabalho e os trabalhadores do SUAS: o enfrentamento necessário na assistência social. In: BRASIL. Ministério do Desenvolvimento Social e Combate à Fome. Gestão do trabalho no âmbito do SUAS: uma contribuição necessária. Brasília: MDS; Secretaria Nacional de Assistência Social, 2011.

SILVEIRA, Jucimeri Isolda. Gestão do trabalho: concepção e significado para o SUAS. In: BRASIL. Ministério do Desenvolvimento Social e Combate à Fome. Gestão do trabalho no âmbito do SUAS: uma contribuição necessária. Brasília: MDS; Secretaria Nacional de Assistência Social, 2011.

230 THIOLLENT, Michel. Crítica metodológica, investigação social e enquete operária. São Paulo: Polis, 1987. 
Capítulo 7

\title{
Ações
}

profissionais

e condições

de trabalho

de assistentes

sociais na Atenção

Primária à Saúde

\author{
Andreia de Oliveira \\ Universidade de Brasília (UnB) \\ andreiao@unb.br \\ Reginaldo Ghiraldelli \\ Universidade de Brasília (UnB) \\ rghiraldelli@unb.br
}

\section{Introdução}

Em anos recentes, observa-se uma significativa ampliação do debate e das pesquisas sobre o exercício profissional dos assistentes sociais, enfatizando a formação, as ações, as atribuições privativas, as 
competências, as demandas, as requisições e as condições de trabalho desses profissionais. Na condição de classe trabalhadora assalariada, o ponto de partida analítico da inserção dos assistentes sociais nos processos coletivos e especializados de trabalho, no âmbito da sociabilidade capitalista, pressupõe o entendimento do significado social da profissão a partir de uma relação dialeticamente indissociável entre trabalho e formação profissional, que se circunscreve na totalidade da vida social.

Desde a gênese do Serviço Social no Brasil, nos anos 1930, como profissão reconhecida, legitimada e inserida na divisão social e técnica do trabalho, que emerge para atender a necessidades sociais e intervir nas múltiplas expressões da "questão social” (IAMAMOTO, 2009), a área da saúde tem absorvido um contingente significativo de assistentes sociais. ${ }^{1}$ De acordo com Iamamoto (2009), os assistentes sociais no Brasil são predominantemente servidores públicos, que atuam na formulação, planejamento, gestão e execução de políticas sociais, dentre as quais a política de saúde. As políticas sociais, compreendidas paradoxalmente como formas e estratégias de respostas às manifestações da “questão social” pela via do Estado e/ou de organizações privadas, ao tempo em que possibilitam o acesso da população aos direitos de cidadania necessários à sua sobrevivência, também atendem aos interesses capitalistas de reprodução do status quo.

Duas décadas após a fundação da primeira escola de Serviço Social em São Paulo, a profissão era reconhecida e regulamentada com base na Lei no 3.252/1957, seguida pelo Decreto no 994/1962, que complementa a primeira regulamentação e dispõe sobre o exercício da profissão (MATOS, 2015). A partir de então, são constituídos e criados os conselhos

\footnotetext{
1 A “questão social”, objeto de investigação e intervenção profissional, precisa ser analisada com base no processo de acumulação e reprodução capitalista, pois, contraditoriamente, na medida em que a produção da riqueza se torna cada vez mais coletivizada, o seu resultado final é sempre apropriado de maneira privada. Produto das desigualdades, das formas de exploração-opressão e dos antagonismos entre as classes sociais, ela assume, mediante o protagonismo, reivindicações e lutas da classe trabalhadora, uma dimensão pública e política, que envolve conformismo, resistência e rebeldia dos indivíduos sociais (IAMAMOTO, 2008).
} 
federal e regionais da profissão, à época intitulados Conselho Federal de Assistentes Sociais (CFAS) e Conselhos Regionais de Assistentes Sociais (CRAS). Atualmente são denominados de Conselho Federal de Serviço Social (CFESS) e Conselhos Regionais de Serviço Social (CRESS). ${ }^{2}$

Para Bravo e Matos (2007), a partir dos anos 1940, observa-se uma ampliação do exercício da profissão na área da saúde, passando este a ser o setor com maior absorção do contingente de assistentes sociais. Além das múltiplas expressões da “questão social”, tendo em vista os fatores estruturais e conjunturais da sociedade capitalista, também justifica a ampliação do mercado profissional da área a formulação de um novo conceito de saúde pela Organização Mundial de Saúde (OMS), em 1948, introduzindo ações de cunho educativo e preventivo, com ênfase no trabalho multidisciplinar. Nesse período, a inserção profissional se dava em âmbito clínico-hospitalar e ambulatorial, e os trabalhadores do Serviço Social eram incorporados aos serviços de saúde por meio de ações baseadas no modelo médico-clínico, ou seja, como profissionais complementares à atividade médica - por isso também chamados de "paramédicos”, denominação dada aos profissionais não médicos que atuavam nos serviços de saúde (MATOS, 2009). Apesar do surgimento dos Centros de Saúde no Brasil, na década de 1920, a incorporação de assistentes sociais nesse espaço ocupacional ocorreu somente a partir dos anos 1970 (BRAVO; MATOS, 2007).

Entre os anos 1960 e 1970, o Serviço Social latino-americano experimenta um processo de revisão de sua base teórico-metodológica, ética, ideopolítica e operacional, que ficou conhecido como Movimento de Reconceituação (NETTO, 2001). ${ }^{3}$ Concomitantemente, nos anos 1970,

2 Em 1940, é criada a primeira entidade da categoria de assistentes sociais, a Associação Brasileira de Assistentes Sociais (ABAS), que tinha seções em quase todos os estados brasileiros. A Associação Brasileira de Ensino em Serviço Social (ABESS) foi criada em 1946, atualmente denominada Associação Brasileira de Ensino e Pesquisa em Serviço Social (ABEPSS). As demais entidades surgem a partir dos anos 1950 e 1960, incluindo associações profissionais, sindicatos, o Conselho Federal e os Conselhos Regionais de Assistentes Sociais, em 1962 (BRAVO; MATOS, 2007).

3 Ao analisar esse processo sob a ótica dialética de rupturas e continuidades, Netto (2001) identifica três direções no Movimento de Reconceituação, que são: a perspectiva 
acontecia no cenário brasileiro o movimento da Reforma Sanitária, que tensionava e questionava o modelo sanitário vigente, até então organizado sob a ótica biomédica e clínico-médica, com estrutura hospitalocêntrica. ${ }^{4}$

A década de 1980, marcada pela saturação-esgotamento do regime militar, crise econômica e abertura política, apresenta avanços emblemáticos no que se refere ao movimento sanitário e às lutas da classe trabalhadora em prol de direitos sociais. Os resultados das reivindicações desses movimentos são notados por ocasião da 8 a Conferência Nacional de Saúde, realizada em 1986 em Brasília (DF), e da promulgação da Constituição Federal em 1988 (CF/88), a qual apresenta um modelo de proteção social baseado em uma concepção de seguridade social que abrange a saúde, a previdência e a assistência social como direitos de cidadania - a saúde como direito universal e dever do Estado; a assistência a quem dela necessitar, mediante critérios de seletividade; e a previdência social com base na lógica do seguro contributivo. Logo após a promulgação constitucional, essas políticas foram regulamentadas por legislações específicas - no caso da saúde, pelas Leis Orgânicas da Saúde n ${ }^{\circ} 8.080 / 1990$ e n 8.142/1990, a partir das quais se regulou o Sistema Único de Saúde (SUS), orientado pelos princípios da universalidade, descentralização, hierarquização dos serviços, regionalização, participação e integralidade da assistência à saúde.

Porém, na contramão dessa ampliação e consolidação dos direitos sociais de cidadania baseados em uma perspectiva universalista, o Brasil dos anos 1990 implementa medidas ideopolíticas neoliberais, transferindo responsabilidades públicas e sociais do Estado para a esfera do mercado, com uma forte tendência de privatização dos bens,

modernizadora, orientada pela matriz estrutural-funcionalista e tecnocrática, hegemônica na profissão nos anos 1960 e 1970; a reatualização do conservadorismo, de inspiração fenomenológica e traços microscópicos na intervenção profissional; e a intenção de ruptura, embasada na tradição marxista, que passa a ser incorporada ao debate profissional nos anos 1980 e adensada nos anos 1990-2000.

4 No caso do processo de renovação do Serviço Social, por se tratar de um movimento que ocorre no interior da profissão, não houve nesse período uma relação direta da categoria profissional com as questões relacionadas à reforma sanitária (BRAVO; MATOS, 2007). 
do patrimônio e dos serviços públicos. A partir disso, são apresentados dois projetos em disputa no que se refere à saúde: o projeto inspirado na reforma sanitária, de defesa da saúde pública, universal, com acesso democrático aos serviços, participação popular e atendimento interdisciplinar, e o projeto privatista, de caráter seletivo, fiscalizatório, individual, assistencialista e orientado para o incentivo aos planos de saúde (BRAVO; MATOS, 2007). Um terceiro projeto é identificado nos governos de Lula da Silva (2003-2010) e Dilma Rousseff (20112016), a saber, o da Reforma Sanitária Flexibilizada, que, em meio às contradições inerentes à implementação do Sistema Único de Saúde, limita as propostas iniciais do projeto de Reforma Sanitária em nome de um SUS possível, com base em arranjos institucionais e gerenciais que relativizam a responsabilidade estatal para com o direito universal à saúde pública (BRAVO; PELAEZ; PINHEIRO, 2018).

No Brasil, a seguridade social é o espaço ocupacional de predominância dos assistentes sociais, o que significa que o Serviço Social atua cotidianamente nas tensões postas entre as necessidades humanas e os interesses político-econômicos do capital financeiro. No caso da saúde, como qualquer outro espaço de atuação, apresentam-se particularidades que demandam, por parte dos profissionais, uma apreensão crítica e consciente da realidade social e dos determinantes da política de saúde, com seus rebatimentos nas ações cotidianas e incidências diretas na vida dos usuários dos serviços prestados. Tendo em vista a sua formação generalista, cabe sublinhar que os profissionais de Serviço Social inseridos nos serviços de saúde não desenvolvem apenas habilidades, conhecimentos, ações, atividades e procedimentos exclusivos e restritos à saúde, como em qualquer outra área das políticas e dos serviços sociais (MATOS, 2009). Porém, mesmo não havendo tal exclusivismo e restrições, esse espaço ocupacional apresenta particularidades, o que exige uma aproximação e apropriação a partir das habilidades e 
dimensões teórico-metodológicas, ético-políticas e técnico-operativas que perpassam a formação e o exercício da profissão. ${ }^{5}$

Resultado de importantes lutas e do protagonismo dos profissionais e das entidades representativas, o Serviço Social é reconhecido como uma profissão da área da saúde, conforme previsto na Resolução n ${ }^{0}$ 218/1997, do Conselho Nacional de Saúde (CNS, 1997) e, nesse sentido, se insere como uma especialização nos processos coletivos de trabalho em saúde. ${ }^{6}$ Esse reconhecimento ocorre porque o Serviço Social atende a uma utilidade social, de modo a responder tanto às necessidades e demandas advindas da população usuária dos serviços prestados, quanto às demandas estruturais-conjunturais-institucionais da ordem social. Por isso, a partir das contradições fundamentais do capitalismo, o Serviço Social ocupa uma função clara e definida na divisão social e técnica do trabalho e, nesse caso, também na política de saúde.

Mesmo inserido em espaços institucionais rigidamente hierarquizados, burocratizados, precarizados e com correlações de forças cada vez mais complexificadas, o Serviço Social, por sua natureza de profissão regulamentada, possui relativa autonomia no exercício cotidiano de suas ações. ${ }^{7}$ Essas relações tensas e conflituosas se apresentam como dilemas e limites, mas também como possibilidades para a realização

5 De forma a atender uma demanda e necessidade da categoria profissional, o CFESS lançou os Parâmetros para atuação de assistentes sociais na política de saúde (CFESS, 2010).

6 A Resolução nº 218, de 6 de março de 1997, do Conselho Nacional de Saúde (CNS), regulamenta as profissões de saúde e, dentre elas, o Serviço Social. São reconhecidas as seguintes categorias profissionais: assistentes sociais, biólogos, profissionais de educação física, enfermeiros, farmacêuticos, fisioterapeutas, fonoaudiólogos, médicos, médicos veterinários, nutricionistas, odontólogos, psicólogos e terapeutas ocupacionais. Cabe sublinhar que o Serviço Social não é uma profissão exclusiva e restrita à área da saúde, mas tem também nela seu lócus de atuação profissional.

7 Essa relativa autonomia está condicionada e circunscrita ao cotidiano das ações do Serviço Social na sua relação com a totalidade social, ou seja, está permeada de disputas, antagonismos, contradições e interesses de classes. Essas ações e intervenções diretas na realidade estão direcionadas, orientadas e legitimadas com base nas diretrizes da formação acadêmico-profissional e no aparato legislativo-normativo que regula o exercício da profissão (IAMAMOTO, 2009). 
do trabalho profissional, em consonância com os princípios e valores que orientam o projeto ético-político da profissão ${ }^{8}$.

O Serviço Social, requisitado em todos os níveis de complexidade da saúde para atender às múltiplas expressões da “questão social”, compõe também a equipe profissional da Atenção Primária à Saúde (APS), que, na relação com outras profissões, contribui para o atendimento e o acesso da população à política de saúde.

Na conjuntura brasileira recente, marcada pelo golpe parlamentar-empresarial-jurídico-midiático, que segue seu curso de regressão e liquidação dos direitos em todos os âmbitos da vida social (saúde, trabalho, educação, previdência, assistência social, habitação etc.), com repercussões nefastas e corrosivas para a sobrevivência da população, o exercício profissional se depara com as adversidades postas na reconfiguração da relação Estado-sociedade, incluindo cortes no orçamento público das políticas sociais, ataques à legislação trabalhista, criminalização das lutas sociais e ameaças aos princípios democráticos, além de privatização, mercantilização e refilantropização dos serviços sociais. ${ }^{9}$

8 Os projetos profissionais expressam a direção social de uma profissão em sintonia com o seu tempo histórico. O projeto ético-político do Serviço Social tem como referência o Código de Ética do Assistente Social de 1993, a Lei de Regulamentação da Profissão n ${ }^{\circ}$ 8.662/93 (CFESS, 2012) e as Diretrizes Curriculares da ABEPSS de 1996. Com base em Netto (2007, p. 4), os projetos profissionais, construídos pela categoria de assistentes sociais, apresentam “[...] a autoimagem de uma profissão, elegem os valores que a legitimam socialmente, delimitam e priorizam seus objetivos e funções, formulam os requisitos (teóricos, práticos e institucionais) para o seu exercício, prescrevem normas para o comportamento dos profissionais e estabelecem as bases das suas relações com os usuários de seus serviços, com as outras profissões e com as organizações e instituições sociais privadas e públicas” (inclusive o Estado, como instituição social pública a que cabe o reconhecimento jurídico dos estatutos profissionais).

9 Medidas regressivas orientadas pela ortodoxia neoliberal e pelos anseios do capital financeiro podem ser constatadas nesse balanço dos últimos anos, sobretudo após o golpe institucional. Dentre elas, incluem-se a Emenda Constitucional n ${ }^{\circ}$ 95/2016, que estabelece o teto dos gastos públicos e congela por 20 anos os investimentos nas políticas sociais, afetando drasticamente políticas como a saúde e a educação; a criação do Programa Criança Feliz, reeditando práticas filantrópicas e assistencialistas pautadas na cultura do primeiro-damismo e do voluntariado; e a Contrarreforma 
Esse quadro conjuntural traz repercussões diretas para o trabalho de assistentes sociais que atuam sobre e na realidade (SANTOS, 2010), diretamente com a formulação, planejamento, gestão e execução de políticas sociais. Nos variados espaços institucionais em que atuam, os assistentes sociais lidam cotidianamente com o processo de radicalização da “questão social”, que se expressa no desemprego estrutural, na violência, no analfabetismo, na miséria, na perda e ausência de direitos, no racismo, no adoecimento, na LGBTfobia e em outras diversas manifestações de exploração e opressão contidas na sociabilidade capitalista.

As mudanças em curso na conjuntura brasileira rebatem no mercado profissional de trabalho dos assistentes sociais, o qual assume novos contornos, diversificando os espaços ocupacionais e fazendo emergirem inéditas requisições e demandas, novas habilidades, competências e atribuições, colocando para o Serviço Social a necessidade de capacidade crítica, analítica, técnica, ética e política sintonizada com o tempo presente (IAMAMOTO, 2009).

Disso advém a necessidade de estudos que busquem uma compreensão e aproximação ao exercício profissional de assistentes sociais na Atenção Primária à Saúde (APS), com ênfase nas ações profissionais e nas condições de trabalho - compreendendo o Serviço Social como inserido nos processos de trabalho em saúde, em sintonia com os princípios e diretrizes do SUS, da Reforma Sanitária e do projeto ético-político da profissão, o que justifica o objetivo e a relevância da presente pesquisa.

Trabalhista (Lei no 13.467/2017), que, sob o discurso falacioso de "modernização das relações de trabalho”, viola direitos sociais e humanos do trabalho, em um amplo processo de degradação, intensificação e precarização do labor. A problematização dos efeitos corrosivos desse cenário após a consolidação do golpe de 2016 não desconsidera as medidas regressivas e de ataques aos direitos da classe trabalhadora adotadas durante o ciclo dos governos Lula (2003-2010) e Dilma (2011-2016), do partido dos Trabalhadores (PT), a exemplo das contrarreformas da previdência social realizadas por ambos nesse período. Com isso, entende-se que a desresponsabilização do Estado brasileiro para com o trato das expressões da "questão social" por meio de políticas públicas e serviços sociais não é um fenômeno recente dos últimos anos; contudo, é agravado neste momento histórico. 


\section{Serviço Social, Saúde e Atenção Primária à Saúde}

O ponto de partida da análise do Serviço Social na política de saúde como uma especialização do trabalho coletivo, sendo a Atenção Primária um dos espaços ocupacionais de absorção desse profissional, é a compreensão do significado social da profissão, da sua utilidade e da sua função na divisão social e técnica do trabalho, a partir do atendimento de necessidades sócio-históricas advindas das forças antagônicas da relação capital versus trabalho e que se materializam nas expressões da “questão social”. Nesse sentido, o exercício profissional, permeado por essas correlações de forças, se faz cotidianamente a partir das necessidades imediatas e mediatas circunscritas na complexa trama das relações sociais capitalistas. ${ }^{10}$ A problematização dessas questões afasta armadilhas analíticas de cunho endógeno, fatalista, aparente, empirista e salvacionista do exercício profissional (IAMAMOTO, 2008; 2009) e permite compreender as dimensões ético-políticas e socioeducativas da profissão, com base em finalidades e intencionalidades que dão subsídios e direcionamentos para as ações cotidianas.

As ações profissionais que envolvem o processo investigativo-interventivo, a formulação, o planejamento, a gestão, a execução de serviços e políticas sociais, os encaminhamentos e a orientação a indivíduos, grupos e famílias, são permeadas e guiadas pelos princípios e direção do projeto ético-político, e podem ser compreendidas como

[...] as atribuições que viabilizam as respostas dos profissionais às requisições colocadas pelas demandas institucionais, como parte da prestação de serviços sociais. Essas ações materializam o caráter interventivo do Serviço Social e dentre as mais comuns estão: executar,

${ }^{10}$ É fundamental, na análise de situações concretas e complexas da totalidade social, a apreensão ontológica das mediações que se constituem na relação dialética e contraditória entre a singularidade (nível dos fatos, da imediaticidade), a universalidade (generalização, âmbito da legalidade, das determinações sociais, dos fenômenos históricos) e a particularidade, entendida como o campo das mediações, da processualidade e da relação entre os níveis singulares e genéricos da realidade social (SANTOS, 2010). 
orientar, agrupar, providenciar, acompanhar, socializar, coordenar, planejar, pesquisar, monitorar, supervisionar, organizar e administrar, estudar e analisar, emitir parecer, assessorar, consultorar. [...] Esses conteúdos estão permeados pelas concepções teóricas, pela perspectiva ético-política, as quais fundamentam e direcionam as escolhas profissionais. (TRINDADE, 2012, p. 70).

No que se refere ao exercício profissional de assistentes sociais na Atenção Primária à Saúde (APS), esse espaço ocupacional é privilegiado no sentido de propiciar o contato direto com usuários dos serviços prestados e, assim, potencializar ações políticas e educativas que fortaleçam a participação, a democratização e ampliação do acesso aos direitos e o controle democrático, de forma a contribuir com a superação da cultura do favor, da subalternidade e das práticas clientelistas, moralistas, culpabilizadoras e imediatistas. ${ }^{11}$

Desse modo, uma intervenção crítica, consciente e propositiva, passa pelo entendimento do conceito ampliado de saúde, que, como uma das expressões da “questão social”, está diretamente relacionada às condições de vida e de trabalho da população e fundamentada no reconhecimento de aspectos sociais, econômicos, políticos, culturais, territoriais, ambientais e tecnológicos.

Nessa linha, a saúde é pensada sob o prisma da determinação social como construção social, em que determinações sociais perpassam as dimensões da vida dos indivíduos em sociedade, compondo a totalidade. Assim, pensar a saúde na perspectiva da determinação social é romper com concepções fragmentadas, isoladas, a-históricas, reducionistas, naturalistas, exclusivamente biológicas, comportamentais e individualistas da vida humana, o que não significa desconsiderar seus aspectos genéticos e fisiológicos (FLEURY-TEIXEIRA, 2009). Com isso, problematizar a saúde é situar dialeticamente o contexto social e as condições objetivas de vida e trabalho da população, tendo em vista o grau

${ }^{11}$ Considerando que não há neutralidade na vida em sociedade, as ações profissionais podem estar direcionadas a valores democráticos e emancipatórios e/ou voltadas para a reprodução e manutenção de relações de dominação, exploração e opressão (GUIMARÃES, 2017). 
de organização da sociedade, o desenvolvimento das forças produtivas e as relações sociais vigentes (ALBUQUERQUE; SILVA, 2014).

No atual cenário de implementação célere de medidas neoliberais, são observados desmontes e ataques aos direitos historicamente conquistados a partir de lutas sociais, travadas no embate de interesses entre as classes sociais. Com isso, a saúde passa a ser vista pelos grupos econômico-financeiros como um negócio rentável e lucrativo, ou seja, uma política que pode ser privatizada, vendida e consumida no mercado. Tal iniciativa ganha proporções a partir de manobras e estratégias do Estado, que, baseado no discurso da crise e da necessidade de redução de suas despesas com as políticas públicas, transfere suas responsabilidades para o setor privado, que se beneficia de recursos públicos.

A CF/88 reconhece o direito universal à saúde, prevendo equidade, integralidade, qualidade no acesso, atendimento e assistência à saúde. Porém, de forma a atender aos anseios mercantis e lucrativos do capital financeiro, o texto constitucional também manteve a concepção privatista dos serviços de saúde, o que possibilita a sua desestatização. Isso revela a arena de interesses e disputas em que se situa a política de saúde no Brasil, colocando, para a classe trabalhadora, a necessidade de resistência e lutas permanentes em defesa da saúde pública, universal, estatal e de qualidade.

No que se refere à Atenção Primária à Saúde, suas experiências emergem nas primeiras décadas do século XX, com concepções teóricas, metodológicas e políticas diferenciadas. Na contemporaneidade, a APS prevê a reorganização do sistema de saúde a partir da prestação de serviços voltados para as necessidades individuais e coletivas da população, segundo uma delimitação geográfica, espacial e territorial. ${ }^{12}$

${ }^{12}$ Conforme Lavras (2011), dentre as experiências germinais de Atenção Primária à Saúde, estão o Relatório Dawson (Reino Unido), de 1920, que concebia a APS como um conjunto sistêmico regionalizado e hierarquizado a partir de definições geográficas, o qual serviu posteriormente de base para a organização dos sistemas de saúde de várias nações, e a Conferência Internacional de Alma-Ata (Cazaquistão), de 1978, que, em síntese, compreendia a assistência e os cuidados primários em saúde como 
No Brasil, os Centros de Saúde, criados nos anos 1920 no estado de São Paulo, enfatizavam ações integradas de educação sanitária e promoção da saúde. Na década de 1960, observa-se uma expansão significativa dos Centros de Saúde e, nos anos 1970, sob a influência do movimento da Reforma Sanitária, as experiências de medicina comunitária (LAVRAS, 2011). ${ }^{13}$

Na década de 1980, a CF/88 apresenta a concepção de Seguridade Social e reconhece a saúde como direito universal de cidadania e dever do Estado, instituindo o SUS com seus princípios e diretrizes. Nos anos 1990, a APS, a partir da municipalização, começa a se estruturar e a se organizar de maneira uniformizada (LAVRAS, 2011), com ações orientadas pelos princípios do SUS, ou seja, universalidade, equidade, integralidade e participação social, sob a responsabilidade dos municípios. O SUS se constitui como um modelo de assistência à saúde, na perspectiva dos direitos, da cidadania, da participação, da descentralização, da democracia e do controle social, o que contribuiu para a incorporação de assistentes sociais em todos os níveis de complexidade, tendo em vista o acirramento das desigualdades sociais diante das contradições postas na sociabilidade capitalista e a reconfiguração do papel do Estado no que se refere ao compromisso com as políticas públicas e os serviços sociais.

A partir da adesão à cartilha neoliberal nos anos 1990, inúmeros são os obstáculos e impasses para assegurar a implementação dos direitos sociais previstos na CF/88. Ainda nos anos 1990, com o objetivo de reorganizar as práticas de saúde e substituir as ações tradicionais de saúde baseadas na lógica curativa e hospitalocêntrica, são criados o Programa de Agentes Comunitários de Saúde (Pacs), em 1991, e o Programa Saúde da Família (PSF), em 1994. Em seguida, em 1997, o

essenciais para o desenvolvimento da comunidade, dos indivíduos e das famílias. Diante disso, observa-se a expansão e o fortalecimento da APS.

${ }^{13}$ No contexto de subsunção da política social às prerrogativas da política econômica de orientação neoliberal, Guimarães (2017) aponta que as experiências de estruturação e organização da Atenção Primária à Saúde (APS) acontecem no auge da crise dos sistemas de proteção social, transferindo responsabilidades do Estado para as famílias. 
PSF é substituído pela Estratégia de Saúde da Família (ESF) ${ }^{14}$ política de Atenção Básica que se orienta pelo trabalho em equipe multiprofissional e pela integralidade, territorialização e hierarquização. Sendo o Serviço Social uma profissão da área da saúde, esse é também um espaço sócio-ocupacional de assistentes sociais, o que evidencia a necessidade e a importância de abordar e conhecer a inserção desses profissionais nos respectivos lócus.

Tais apontamentos justificam a necessidade de pesquisas sobre a inserção do Serviço Social na Atenção Primária à Saúde, enfatizando as ações profissionais e as condições de trabalho. No intuito de suprir necessidades e lacunas nesse âmbito, a presente pesquisa objetivou se aproximar dessa realidade. A partir de um recorte teórico-metodológico, mesmo que de forma limitada e aproximativa, apresentamos os resultados obtidos no percurso investigativo.

\section{O percurso metodológico-investigativo e a aproximação ao cotidiano de trabalho de assistentes sociais}

A presente pesquisa, resultado de revisão bibliográfica sobre o tema, análise documental e pesquisa de campo, aborda as ações profissionais e condições de trabalho de assistentes sociais a partir de uma interpretação qualitativa, mas sem desconsiderar os dados quantitativos obtidos e incorporados ao percurso investigativo, tendo em vista seus aspectos complementares (MINAYO, 2010). Pretendeu-se analisar o exercício profissional no tempo presente, a partir das condições objetivas, contraditórias e complexas da vida social. Para alcançar os resultados aproximados, mapear o universo quantitativo dos profissionais inseridos nesse espaço ocupacional e estabelecer comunicação direta com assistentes sociais, foi fundamental a parceria com a Gerência de Serviço Social da Secretaria de Estado de

${ }^{14}$ A Estratégia Saúde da Família (ESF) emerge como modelo essencial de organização da Atenção Primária à Saúde e da Atenção Básica no Brasil, com o propósito de catalisar o processo saúde-doença dos indivíduos na instância da família e na esfera das comunidades. 
Saúde do Distrito Federal (GESS/SES/DF), que disponibilizou as informações necessárias ao contato entre pesquisadores e assistentes sociais vinculados à Atenção Primária à Saúde. ${ }^{15}$ Após o levantamento do quantitativo de profissionais, foram cedidos pela Gerência os contatos eletrônicos desses profissionais para a aplicação do questionário, elaborado pela Plataforma Google e enviado virtualmente a toda a equipe que compunha o banco de dados. Junto ao questionário, foram apresentados os objetivos da pesquisa, contendo as orientações sobre os cuidados éticos acerca do sigilo, tendo em vista que o projeto foi apreciado e aprovado pelo Comitê de Ética em Pesquisa (CEP) da Universidade de Brasília (UnB). Para atender às recomendações éticas, todos os participantes assinaram o Termo de Consentimento Livre e Esclarecido (TCLE) e suas identificações foram mantidas em anonimato. Em seguida, após a sistematização dos dados obtidos por meio das respostas ao questionário on-line, realizaram-se entrevistas semiestruturadas com assistentes sociais.

De um universo de 95 assistentes sociais ${ }^{16}$ com atuação no âmbito da Atenção Primária à Saúde no Distrito Federal, 26 profissionais, ou seja, o correspondente a 27,37\% do total, responderam ao questionário aplicado on-line na plataforma Google, sendo eles lotados nos seguintes espaços ocupacionais: 11 profissionais inseridos em Centros de Saúde; seis no Núcleo de Apoio à Saúde da Família (Nasf); cinco na Atenção

${ }^{15}$ Registramos o nosso agradecimento à Gerência de Serviço Social da Secretaria de Saúde do Distrito Federal (GESS/SES/DF) pela colaboração com a pesquisa em diversas etapas, especialmente à assistente social Michelle da Costa Martins, que integrou a equipe técnica da pesquisa; aos estudantes de graduação que participaram da pesquisa, tanto na iniciação científica, quanto na realização de trabalhos de conclusão de curso (Ana Ketelin Justino Ferreira, Ana Paula Barbosa Cruz, Beatriz Fonseca Cerqueira, Jozieli Maria Sousa Barros, Júlia Caroline Pires, Juliana Oliveira de Almeida, Murilo Martins Braga, Raísa Nunes dos Santos Garcia e Valdenise Barreto de Almeida); e também aos profissionais de Serviço Social inseridos na Atenção Primária à Saúde do Distrito Federal, que participaram como sujeitos de pesquisa.

${ }^{16}$ Total de assistentes sociais com atuação na Atenção Primária à Saúde no Distrito Federal em abril de 2016, período em que a pesquisa de campo foi iniciada. O questionário on-line foi aplicado no período de abril a outubro de 2016. 
à Saúde no Sistema Prisional; três na Equipe de Atenção Domiciliar (EAD); e um no Consultório na Rua. ${ }^{17}$

Após a sistematização dos dados obtidos por meio das respostas aos questionários, iniciou-se a etapa de realização das entrevistas semiestruturadas. ${ }^{18}$ Participaram das entrevistas 15 assistentes sociais que atuam na APS do Distrito Federal, sendo cinco profissionais inseridos em Centros de Saúde; quatro na Atenção à Saúde no Sistema Prisional; dois no Núcleo de Apoio à Saúde da Família (Nasf); dois na Equipe de Atenção Domiciliar (EAD); e dois no Consultório na Rua. Alguns assistentes sociais participantes da entrevista também responderam ao questionário on-line, enquanto outros participaram apenas de uma das etapas da pesquisa empírica, ou seja, responderam apenas ao questionário on-line, ou participaram somente da entrevista semiestruturada.

No que se refere às particularidades da Atenção Primária à Saúde no Distrito Federal, Göttems (2010) sinaliza sua implementação, nos anos 1970, a partir de planos e medidas governamentais, informando que, historicamente, a APS é atravessada por configurações e adequações diferenciadas e submetida a alterações a cada gestão governamental, o que contribui para a descontinuidade e desarticulação da rede de serviços em todos os níveis de complexidade. O Plano Distrital de

${ }^{17} \mathrm{O}$ total de profissionais na Atenção Primária à Saúde no Distrito Federal era de 95 pessoas, conforme os dados obtidos pela Gerência de Serviço Social da Secretaria de Saúde no período que abrange a realização da pesquisa, sendo que, por serviço e unidade, esse número estava distribuído da seguinte forma: Centro de Saúde, 62 assistentes sociais; Núcleo de Apoio à Saúde da Família, dez assistentes sociais; Equipe de Atenção Domiciliar, 11 assistentes sociais; Consultório na Rua, três assistentes sociais; e Atenção à Saúde no Sistema Prisional, nove assistentes sociais.

${ }^{18}$ Algumas entrevistas foram realizadas nos respectivos espaços ocupacionais de atuação, e outras, nas instalações da Gerência de Serviço Social da SES/DF. Todas as entrevistas foram gravadas, transcritas e, em seguida, analisadas. Os entrevistados assinaram o TCLE, seguindo as recomendações éticas. De forma a manter o sigilo, a identificação desses sujeitos foi estabelecida de acordo com a sigla AS para se referir a assistente social, seguida pela sigla do serviço-unidade de inserção, ou seja: Centro de Saúde (AS-CS), Consultório na Rua (AS-CR), Equipe de Atenção Domiciliar (AS-EAD), Núcleo de Apoio à Saúde da Família (AS-Nasf) e Saúde Prisional (ASSP), seguida de ordem numérica, de acordo com o quantitativo de participantes. 
Saúde vigente (2016-2019) destaca a necessidade do fortalecimento da Estratégia de Saúde da Família (ESF), definida como o modelo de organização da APS, com meta de expansão, qualificação e ampliação de equipes conforme as diferentes necessidades, demandas da população e particularidades locais, tais como Equipe de Saúde da Família, Equipe de Saúde Rural, Núcleo de Apoio à Saúde da Família, Unidades Básicas de Saúde, Consultório na Rua, dentre outros.

Diante disso, a partir da obtenção de dados resultantes do questionário e das entrevistas semiestruturadas, é possível apresentar em linhas gerais elementos que esboçam o perfil profissional de assistentes sociais inseridos na Atenção Primária à Saúde do Distrito Federal. Os resultados identificaram a predominância feminina como uma marca histórica da profissão (IAMAMOTO, 2009) e o catolicismo como religião professada pela maioria, seguido pelo protestantismo e o kardecismo, consecutivamente. Todos os profissionais, sendo servidores públicos, possuíam vínculo estatutário de trabalho, sendo que apenas um dos participantes cumpria uma jornada laboral de 20 horas semanais, já que os demais informaram trabalhar 40 horas semanais. Tal dado aponta desafios para a categoria profissional no que se refere à implantação da Lei $n^{\circ} 12.317 / 2010$, que estabelece a jornada laboral de 30 horas semanais sem redução de salário para assistentes sociais, uma conquista recente que expressa a capacidade político-organizativa e as lutas coletivas do Serviço Social brasileiro. Sobre o perfil etário, eram profissionais com idade superior a 28 anos e inferior a 59 anos. No que se refere ao tempo de atuação profissional, seja como assistentes sociais em diversos espaços ocupacionais e áreas, seja somente na área da saúde, os dados revelam um período mínimo de dois anos e, em alguns casos, superior a 20 anos. Em relação à renda média individual, a remuneração variou de sete a 16 salários mínimos. Outro dado relevante diz respeito à qualificação profissional, pois se observa que a maioria havia realizado formações no âmbito da pós-graduação, seja lato sensu (especializações), seja stricto sensu (mestrado e/ou doutorado), voltadas para as áreas de Serviço Social, Política Social e/ou de saúde (como Saúde Pública, Saúde 
Mental, Saúde da Família, Saúde Materno-Infantil, dentre outros enfoques), além da residência multiprofissional.

Em relação ao processo de formação continuada, os profissionais procuravam manter-se atualizados, naquilo que diz respeito à profissão, por meio da participação em palestras, eventos, simpósios, congressos, fóruns de supervisão de estágio, cursos, leituras de livros e artigos, congressos da categoria profissional e áreas afins, dentre as oportunidades de formação oferecidas pela Gerência de Serviço Social, pelo Ministério da Saúde e pela SES-DF.

A Gerência de Serviço Social sempre encaminha os cursos de capacitação e eu participo de quase todos, porque acho importante. $\mathrm{O}$ assistente social tem que estar sempre capacitado. (AS-SP 01)

As ações de formação continuada contribuem para a qualificação, o desenvolvimento de habilidades e competências e a apreensão histórico-crítica das múltiplas e complexas manifestações da "questão social”, a partir de aportes teórico-metodológicos e ético-políticos que fornecem subsídios para a intervenção profissional que se dá na concretude e na cotidianidade da realidade social. ${ }^{19}$ Nesse sentido, é importante a defesa e a implementação de políticas voltadas para uma formação crítica e permanente dos profissionais, com o escopo de superar ações imediatistas, moralistas, culpabilizadoras e pragmáticas, pautadas na lógica instrumental, gerencial, empirista, focalizada, a-histórica e de padronização dos procedimentos a partir da incorporação de manuais institucionais e autoexplicativos (MOTA, 2014). ${ }^{20}$

${ }^{19}$ Para Matos (2015, p. 685), o cotidiano é o espaço das respostas imediatas em todas as esferas da sociabilidade, inclusive as relacionadas ao trabalho. Isso significa que um profissional qualificado dará respostas mais qualificadas às demandas apresentadas. Se os valores emancipatórios do projeto ético-político forem de fato internalizados, as repostas profissionais serão emancipatórias, ou seja, estarão na contramão da sociabilidade burguesa que naturaliza a desigualdade social, estimula o preconceito e desqualifica os indivíduos que estão fora do padrão dominante.

${ }^{20}$ Bravo e Matos (2007) ressaltam a importância das diretrizes das profissões de saúde ao enfatizarem uma formação crítica e generalista, na perspectiva da Reforma 
Ainda sobre as diversas formas, estratégias e possibilidades de formação permanente, os profissionais retrataram a importância da residência multiprofissional em saúde e o estágio supervisionado como espaços de interlocução continuada e aprendizado coletivo. A maioria dos assistentes sociais entrevistados declararam supervisionar ou haver supervisionado estágio em algum momento, destacando o seu significado pedagógico no processo formativo. Entretanto, expressaram dificuldades, obstáculos e limitações institucionais para o acompanhamento de estagiários diante das condições de infraestrutura, da burocracia, ${ }^{21}$ da precarização e da sobrecarga de trabalho.

O estágio tem um papel fundamental. Quando você encontra um supervisor bom, ele muda a sua visão da profissão. (AS-CS 02)

O estágio é uma experiência sempre muito rica; a troca é muito rica. (AS-CS 01)

Já supervisionei no HRAN porque tinha computador, tinha sala; já supervisionei na assistência, mas aqui no centro de saúde ainda não, porque eu nunca tive uma sala. Como é que eu vou colocar uma pessoa aqui? (AS-CS 05)

Em relação às ações e atividades desenvolvidas na APS, foram destacadas, seguindo uma ordem de maior recorrência, as seguintes: atendimento e orientação a indivíduos, grupos e famílias; visitas domiciliares e institucionais; elaboração de estudo e relatório social; reuniões

Sanitária e do SUS, ou seja, uma formação que não seja fragmentada ou meramente técnico-instrumental.

${ }^{21}$ A formação continuada deve estimular o processo de ensino-aprendizagem, a aquisição de habilidades e o desenvolvimento de competências a partir de aportes teóricos e críticos sobre a realidade social, de modo que o profissional não sucumba ao cumprimento de normas, regras, cartilhas e prescrições institucionais, recaindo na burocratização e na lógica da razão instrumental. Para Iamamoto (2009), a racionalidade burocrática, ao contrário daquilo que proclama, ou seja, de atender os interesses gerais da sociedade, na verdade se revela como irrealidade de um mundo invertido. 
da equipe multiprofissional; execução de políticas sociais; atividades de mobilização, organização e participação social; supervisão de estágio; elaboração de projetos sociais; monitoramento de planos, programas e projetos; e formulação, planejamento e avaliação de políticas sociais.

Diante das particularidades desse espaço ocupacional, os profissionais enfatizam a importância das atividades realizadas com grupos sociais, no sentido de discutir questões atinentes à saúde e aos direitos sociais. Vale salientar que as ações profissionais não são neutras e nem um fim em si (GUIMARÃES, 2017), pois elas se realizam na processualidade histórica, com direção, finalidades e escolhas entre as alternativas postas na concretude social. Isso possibilita compreender a dimensão política e educativa do exercício profissional, que pode reforçar e reproduzir relações de dominação-exploração-opressão, ou construir, a partir das ações cotidianas, alternativas concretas e comprometidas com valores democráticos e emancipatórios. Nessa perspectiva, os profissionais destacam a importância da dimensão pedagógica do Serviço Social:

A Atenção Básica é o ponto de partida de tudo. Então, se tiver um bom acolhimento aqui, as chances dos danos e das morbidades diminuem. (AS-CS 02)

As ações desenvolvidas pelo Núcleo de Apoio à Saúde da Família (Nasf) no Distrito Federal são realizadas, em sua maior parte, por meio de equipe multidisciplinar, com ênfase no matriciamento às Equipes de Saúde da Família (ESF). Sobre o matriciamento, Campos e Domiti (2007) apontam, dentre as suas características, propostas e objetivos, a superação de práticas tradicionais, autoritárias e verticalizadas, pois até então as tarefas se organizavam de modo repetitivo, fragmentado e parcial, voltadas para a eficiência e eficácia e o adestramento do trabalhador. Em linhas gerais, as entrevistas apresentam a organização do trabalho no Nasf.

É um núcleo que tem vários profissionais de diferentes saberes, diferentes formações que dão apoio matricial às 
equipes de saúde da família, equipes básicas que geralmente têm médico, enfermeiro, agente comunitário de saúde, técnico em enfermagem e o pessoal da saúde bucal. O Nasf aqui, especificamente, está composto por mim, que sou assistente social, e tem a fonoaudióloga, tem um pediatra, tem dois nutricionistas, e tinha uma terapeuta ocupacional que agora foi para a gerência. Muda de acordo com as especialidades de cada Nasf. Cada um tem um formato, mas existem várias especialidades: psicólogo, psiquiatra. A gente tinha homeopata também uma época, fisioterapeuta, até educador físico. (AS-Nasf 01)

A gente não é porta de entrada, é de apoio matricial. Mas existe atendimento individual, existe demanda espontânea, existe visita, todas essas coisas. A diferença é que a gente tenta fazer isso sempre junto com as equipes, é tudo discutido em conjunto, para qualificar, não ficar só em atendimentos pontuais, sem interlocução de nada. Matriciamento é essa ideia de empoderar as equipes para conseguirem lidar com demandas que vão surgindo, de acordo com cada conhecimento que a gente tem enquanto profissionais de especialidades específicas. (AS-Nasf 01)

A gente tem aqui o Projeto Terapêutico Singular, que é um projeto que você faz do paciente, quando é um paciente que engloba mais de um, dois ou três profissionais; a gente tenta fazer esse projeto, mas não é uma coisa em que a gente ainda está atuando muito, porque falta tempo de sentar e planejar, mas estamos tentando adaptar, trabalhamos em equipe. (AS-Nasf 02)

A centralidade do trabalho do Nasf, como se observa, está direcionada para o suporte às ESF e, desse modo, a ênfase não recai no atendimento aos usuários, apesar da existência dessa abordagem nas situações necessárias. Esse suporte às equipes aparece caracterizado como apoio institucional e/ou matricial, de modo que as ações desenvolvidas se vinculam a essa atividade por meio de uma postura de trabalho coletivo, dialógico e horizontal. 
O processo de trabalho coletivo em saúde pode assumir posturas e tendências diversas, o que requer de assistentes sociais a apreensão crítica do seu objeto de investigação-intervenção, das atribuições e competências profissionais e dos princípios ético-políticos que embasam o projeto da profissão, de forma que sua atuação seja orientada por meios e fins comprometidos com os interesses e necessidades da classe trabalhadora. Dentre as ações presentes na APS, considerando a heterogeneidade das falas, estão o acolhimento, a orientação social, o planejamento das atividades, as visitas domiciliares, a gestão, a supervisão de estágio, o trabalho em equipe, a abordagem de rua, a educação popular e a proposta do Projeto Terapêutico Singular.

O trabalho consiste na internação domiciliar; o principal instrumento de trabalho é a visita domiciliar. A gente faz um serviço para pacientes de doenças crônicas não transmissíveis, cuidados paliativos oncológicos. (AS-EAD 01)

O serviço é a assistência domiciliar, dar assistência em domicílio aos pacientes de média complexidade. $\mathrm{Na}$ maioria dos casos, atendemos demências em estados avançados, acamados, AVC e alguns cuidados paliativos. O trabalho nosso consiste em capacitar os cuidadores, dar assistência aos cuidadores. (AS-EAD 02)

O Consultório na Rua, dentro da Atenção Básica, está para a população em situação de rua como o posto de saúde está para as demais pessoas da comunidade. Por isso, a pessoa está na rua, não te conhece, é necessário conquistar sua confiança. (AS-CR 02)

O nosso trabalho tem várias dimensões. Tem a dimensão assistencial, a dimensão educativa, que eu faço na escola, a dimensão da gestão, e tem ainda a dimensão do ensino, que é o estagiário, que eu recebo todo ano. (AS-CS 02)

No atendimento individual, os demais profissionais fazem as consultas, mas o meu atendimento é diferente. É um atendimento específico, que em geral os 
profissionais aqui não fazem. Mas as práticas educativas eles também têm, só que a abordagem é diferente. Eles costumam fazer no formato de palestras, e eu trabalho mais com as práticas em saúde mesmo, com educação popular, com roda de conversa, é um pouco diferente em relação à metodologia. (AS-CS 05)

Em algumas situações, a partir de um viés psicoterapêutico no contato e no atendimento profissional de assistentes sociais com usuários dos serviços prestados, pode acontecer uma abordagem de cunho terapêutico, subjetivista e individualista (GUIMARÃES, 2017), desconsiderando as condições concretas, históricas, coletivas e objetivas presentes na totalidade social. Nesse caso, pode-se incorrer nas armadilhas de naturalização, de patologização e de despolitização das expressões da “questão social”. Por outro lado, mesmo nos limites postos pela realidade e na contramão da naturalização das desigualdades sociais, os assistentes sociais inseridos nos processos contraditórios de trabalho em saúde podem contribuir e cooperar, a partir de sua dimensão político-educativa e da prestação de serviços de qualidade, para o acesso e viabilização dos direitos sociais dos usuários, a democratização da gestão público-estatal, a socialização de informações, o fortalecimento e alargamento de canais participativos e de controle democrático e demais lutas ampliadas da classe trabalhadora (IAMAMOTO, 2008; 2009).

Em relação aos instrumentos técnicos e operativos incorporados no cotidiano das ações profissionais, foram mencionados, seguindo a ordem de maior incidência nas respostas, os seguintes: relatório social; encaminhamentos para a rede de proteção social; entrevista social; reuniões (com equipe, com famílias, com cuidadores); visita domiciliar e institucional; estudo social; parecer social; atas. Foi mencionado o uso do TrakCare (sistema unificado de informações de saúde), que corresponde ao registro em prontuário eletrônico, além da incorporação cada vez mais recorrente do telefone celular, com o recurso do WhatsApp. A dimensão técnico-operativa 
[...] é a forma de aparecer da profissão, pela qual é conhecida e reconhecida. Dela emana a imagem social da profissão e sua autoimagem. [...]. É a dimensão que dá visibilidade social à profissão. [...] a intervenção de natureza técnico-operativa não é neutra: ela está travejada pela dimensão ético-política e esta, por sua vez, encontra-se aportada em fundamentos teóricos [...]. (GUERRA, 2012, p. 40).

De acordo com os relatos, o exercício profissional se faz na interface com os princípios do código de ética e com a direção do projeto ético-político, expressando-se cotidianamente nos atendimentos e nas problematizações no ambiente de trabalho com a equipe multidisciplinar, na prestação de serviços de qualidade, na atuação comprometida com a democratização do acesso aos serviços e políticas sociais, nas relações horizontais estabelecidas com os usuários e a equipe, por meio de posturas não arbitrárias e contrárias a todas as formas de preconceito e discriminação de gênero, raça, etnia, classe social, nacionalidade, religião e orientação sexual, além das questões pertinentes ao sigilo profissional, que, ao assegurar aos profissionais a manutenção da confidencialidade sobre as informações dos usuários, protegem o direito desses mesmos usuários na relação com os demais profissionais da equipe.

Ainda assim, com relação ao sigilo profissional, embora os entrevistados relatem resguardá-lo, também destacam a dificuldade de sua efetivação, tendo em vista a característica do trabalho realizado nas diferentes ramificações de serviços, como é o caso do sistema prisional. Para assistentes sociais inseridos nesse espaço ocupacional, o sigilo constitui uma dimensão de difícil materialização, diante das particularidades do local de trabalho, em função da presença da escolta durante o atendimento. Isso significa que um agente penitenciário acompanha o interno e o aguarda na porta, do lado de fora da sala. Desse modo, por motivos de "segurança”, a porta deve permanecer entreaberta. Tal medida possibilita a escuta, pelo agente penitenciário, dos relatos do 
interno, o que fragiliza o sigilo e a confidencialidade na relação entre assistente social e usuário. ${ }^{22}$

A partir das narrativas, observa-se a existência de autonomia profissional na instituição e junto à equipe. Entretanto, os entrevistados ressaltam que essa autonomia é relativa, uma vez que a falta de condições e infraestrutura adequadas para o trabalho inviabiliza a realização de várias atividades. Outro aspecto destacado se refere à fragilidade da rede de proteção social para a garantia de um atendimento integral e de qualidade aos usuários.

Junto à equipe eu tenho autonomia, mas o que freia tudo isso é que você fica limitada a uma estrutura de Estado. Chega uma hora que você fica desorientada sobre o que vai fazer, porque a família precisa de tanto suporte que o Estado não dá. (AS-EAD 01)

É relativa, não tem tanto essa questão da interferência no atendimento que é feito, no material que é produzido, mas às vezes, quando é para você desenvolver algum outro tipo de atividade que não está nesse do atendimento individual, aí geralmente você não tem muito apoio. Então, assim, é uma autonomia relativa; você tem autonomia para fazer? Tem, mas se efetivamente vai conseguir fazer aquilo... (AS-CS 03)

Os depoimentos contribuem para a compreensão da inserção profissional na arena contraditória da sociabilidade capitalista, pois os assistentes sociais atuam cotidianamente nas relações conflituosas entre os interesses do capital e do trabalho (GUERRA, 2007). Por isso, faz-se necessário analisar o exercício profissional sob o ângulo das determinações estruturais e conjunturais presentes na sociedade. A saúde, uma das áreas de atuação do Serviço Social, é um espaço privilegiado de aprofundamento da democracia, da cidadania, da interdisciplinaridade,

22 De acordo com o Código de Ética do/a Assistente Social de 1993, em seu Capítulo $\mathrm{V}$ (artigos 15, 16, 17 e 18), o sigilo profissional é reconhecido como um direito e um dever de assistentes sociais (CFESS, 2012). 
da participação popular e das lutas de classes (BRAVO, 2007), em que estão postos projetos em disputa. De um lado, um projeto privatista orientado pela ortodoxia neoliberal e, de outro, o projeto da Reforma Sanitária, consubstanciado na defesa da saúde pública como direito universal de cidadania, e que se encontra fortemente ameaçado.

A pesquisa também identificou um processo de intensificação e precarização do trabalho, em que assistentes sociais avaliam criticamente as condições degradantes e desgastantes às quais estão submetidos, em uma conjuntura de carência de materiais básicos para o exercício da profissão, como a falta de papel, de carro, de telefone, de computador e de salas para atendimento individual, dentre outros insumos e recursos indispensáveis à realização das atividades cotidianas.

Falta papel, coisas básicas como toner, luva, lençol; o telefone está cortado há um mês. A gente não tem carro da instituição. Somos em oito dentro daquela salinha, e quando vamos fazer atendimento individual e tal, é uma batalha para conseguir consultório vazio. A gente tem que ver quem é que está de folga. Para fazer atendimento específico é difícil, mas a gente dá conta, tem que ser muito criativo para trabalhar na saúde. (AS-Nasf 01)

A gente fica frustrada em algumas coisas, como, por exemplo, falta de material. Queremos comprar um quadro agora, desses para escrever. Falta a parte de suprimento, não tem apoio da Secretaria em algumas coisas. Essa coisa do carro mesmo, pega muito, porque se acontece alguma coisa com a gente no meio da rua, a Secretaria não quer saber se o carro estragou, se você foi baleada fazendo a visita. Então, também não tem segurança nesse sentido. (AS-Nasf 02)

Não só para o Serviço Social, mas para todos da equipe, o espaço é muito ruim, nós não temos espaço aqui. É insalubre, pequeno, a equipe é muito grande com pouco espaço. (AS-EAD 02) 
A partir das narrativas, observa-se que a indisponibilidade de carro e motorista nas unidades e serviços tem levado ao uso do veículo particular de assistentes sociais para a realização de visitas domiciliares e institucionais. No caso da disponibilidade do transporte pela Secretaria de Estado de Saúde do Distrito Federal (SES/DF), há situações em que a função de condutor do veículo oficial é transferida ao profissional de saúde. Ou seja, no contexto de um mundo do trabalho polivalente, assistentes sociais também assumem a tarefa de motoristas. $\mathrm{O}$ uso de recursos próprios para a realização do trabalho é recorrente nas falas, especialmente do carro particular, do computador e do telefone celular.

A gente faz visita normalmente a pé porque é perto da área. Mas quando é para fazer visita intersetorial ou mais longe, é no carro próprio mesmo. (AS-Nasf 01)

Atualmente não tenho telefone, mas já tenho computador. Sempre fiquei sem computador, sempre levei o meu computador. Aí quando tem o computador, tiraram o telefone, então estou sem telefone, e estou com computador agora. (AS-SP 03)

O acirramento das medidas neoliberais de ajuste e austeridade, com efeitos diretos nos cortes e redução do orçamento público, também se traduz de modo significativo na esfera das condições de trabalho, ao desencadear processos de desgaste e adoecimento da classe trabalhadora. Trata-se de uma situação também vivenciada por assistentes sociais que atuam na Atenção Primária à Saúde no Distrito Federal.

Com base nos depoimentos, são recorrentes as situações que suscitam formas desgastantes de trabalho para os assistentes sociais, tendo em vista as requisições, cobranças, pressões, sobrecarga, metas de produtividade e número reduzido de profissionais para o atendimento de demandas cada vez mais ampliadas e complexificadas diante da radicalização da “questão social”. Essa problemática não se restringe ao universo do exercício profissional dos assistentes sociais, mas, em uma perspectiva de totalidade, está relacionada às questões estruturais e conjunturais da sociedade capitalista. Porém, esses profissionais 
discorrem sobre particularidades em seu âmbito de atuação que se diferenciam das de outros profissionais da equipe multidisciplinar de saúde, como a necessidade de um período de tempo mais prolongado na atenção aos usuários, pois, em diversas situações, o atendimento introdutório se desdobra em outras atividades, tais como a realização de contatos com a rede socioassistencial, visitas institucionais, encaminhamentos, dentre outras ações.

Muitas vezes a gente tem um volume de trabalho maior, pois me demanda entrar em contato com três ou quatro locais no mínimo, articular com várias coisas, para ver se dá certo ou não. Então, isso aumenta muito o trabalho, não tem condição a energia que você gasta em cada atendimento. (AS-CR 01)

Cobrança, pressão, porque a gente trabalha com pessoas em situação de rua, pessoas dependentes de álcool e outras drogas, sofrimento mental. Daí você percebe que não está preparada para atender e isso demanda outro serviço. Então, há uma cobrança muito grande. (AS-EAD 02)

Faz um atendimento e muitas vezes ele começa quando a pessoa vai embora, porque tem desdobramentos de articulação que vai ter que fazer, de sentar com a equipe e discutir. Então, isso me exaure as forças, as energias. Enquanto o atendimento de um médico dura 15 minutos, o nosso dura no mínimo 30, e olhe lá. (AS-CS 01)

Eu fico sobrecarregada. Dentro do meu horário de trabalho, eu não estou conseguindo resolver tudo aquilo que preciso. Tem mais demandas de pessoas para serem atendidas. A pobreza aumentou, as relações estão mais difíceis, a criminalidade aumentou e isso tudo faz com que a demanda de trabalho aumente. Você vê a questão do envelhecimento, a questão do sofrimento mental, a dependência de álcool e outras drogas. E associado a isso aumentou a demanda por serviço, mas não aumentou o número de profissionais. Então, acaba tendo uma sobrecarga de trabalho. (AS-EAD 01) 
Geralmente ocorrem pressões que estão relacionadas à resolução momentânea dos casos; por exemplo, se encaminha uma determinada situação, e acha que vai ser resolvida de maneira muito simples ou muito tranquila, e a gente sabe a complexidade das demandas que a gente atende. (AS-CS 03)

Os efeitos das transformações societárias, em que o mundo do trabalho se revela cada vez mais degradante, intensificado, adoecido e precarizado, incidem no modo de ser da classe trabalhadora, tanto em suas dimensões objetivas quanto subjetivas. Isso se observa também no cotidiano de trabalho dos assistentes sociais, parte da classe trabalhadora assalariada (RAICHELIS, 2011) que, ao se inserir na dinâmica dos processos laborais, não está isenta e incólume em relação às consequências deletérias e aos desdobramentos estruturais e conjunturais da sociedade capitalista. Dessa forma, as implicações perversas e nocivas dessa sociabilidade que se pauta nos princípios da competitividade, da meritocracia e do individualismo são visíveis e devastadoras, inerentes a um mundo do trabalho adoecido e que está em um constante processo de debilitação.

Eu vim para cá doente, com vários tipos de problema. Tenho duas hérnias de disco e foi por conta de trabalho. (AS-CS 02)

Eu fiquei afastada 12 dias por causa de coisas que vivi aqui no trabalho, e não existe nenhum tipo de política voltada para a saúde, para a nossa saúde. Pelo contrário, quando isso aparece, as pessoas não sabem lidar, não sabem acolher. (AS-CR 01)

Quem nunca ficou doente naquele lugar? Eu sou a mulher que mais deu atestado ali, já emocional; eu sofro de enxaqueca crônica. O ambiente é pesado, a energia é pesada, o espaço é ruim. (AS-SP 02) 
As novas requisições, exigências e imposições colocadas para a classe trabalhadora, em um mundo do trabalho que se metamorfoseia e se reestrutura em tempos de crise estrutural do capital em sua dimensão financeira, demonstram a face e a natureza perversa, descontrolada e destruidora do capitalismo, em uma lógica de desumanização, de banalização do humano (IAMAMOTO, 2008) em proveito de interesses mercantis e lucrativos. Isso se constata nos processos de intensificação e precarização laboral, além do adoecimento em função do trabalho, como se verifica no caso dos assistentes sociais, que, juntamente com outras profissões e segmentos de trabalhadores, constituem a sociedade que vive e sobrevive do trabalho.

Em um mundo do trabalho cada vez mais complexificado, precarizado, intensificado e adoecido, com as medidas neoliberais em curso, por meio de privatizações ${ }^{23}$ e redefinição das responsabilidades do Estado com a “coisa pública”, as expressões da "questão social” se agravam e se radicalizam, colocando para o Serviço Social brasileiro a necessidade permanente de resistir no cotidiano e de se somar às lutas da classe trabalhadora. Nesse processo, é notório e reconhecido o protagonismo das entidades profissionais representadas pelo Conselho Federal de Serviço Social e Conselhos Regionais de Serviço Social (conjunto CFESS-CRESS), pela Associação Brasileira de Ensino e Pesquisa em Serviço Social (ABEPSS) e pela Executiva Nacional de Estudantes de Serviço Social (Enesso).

\footnotetext{
${ }^{23}$ Dentre as medidas de privatização da política de saúde no Brasil, sob a orientação do Banco Mundial e do capital financeiro, está a implantação das Organizações Sociais, das fundações públicas de direito privado, da EBSERH (Empresa Brasileira de Serviços Hospitalares) e dos planos populares de saúde, que ameaçam a sustentação do SUS e representam a derruição de direitos historicamente conquistados. Emerge, nessa conjuntura político-econômica brasileira de ataques aos direitos sociais, um discurso do SUS possível (GUIMARÃES, 2017) que, sob a ótica “flexível” do direito à saúde, caminha na contramão da perspectiva universalista.
} 


\section{Considerações finais}

A realização da pesquisa com assistentes sociais na Atenção Primária à Saúde no Distrito Federal, mesmo abrangendo somente uma das dimensões e particularidades da área da saúde e apenas um dos seus lócus de atuação profissional - considerando a sua amplitude e complexidade -, e apesar da especificidade do universo que constituiu o seu recorte (no caso, o DF), apresentou informações e dados de uma realidade local que se insere em uma totalidade social.

Os resultados obtidos apontam para a necessidade de aprofundamento e de continuidade de estudos sobre o tema, incluindo enfoques e abordagens voltadas a outras localidades, regiões, áreas e demais espaços ocupacionais, de forma a conhecer as ações, atribuições, competências profissionais e condições de trabalho de assistentes sociais no atual contexto de profunda crise do capital. Essa crise redefine o mundo do trabalho e as funções do Estado no trato da "questão social" por meio de políticas públicas e serviços sociais, o que incide fortemente sobre o exercício profissional dos assistentes sociais, porquanto estes desempenham sua profissão no âmbito das políticas sociais.

Pesquisas sobre esse exercício profissional, que analisem a configuração dos espaços sócio-ocupacionais na contemporaneidade, com ênfase nas demandas sociais, competências, requisições, ações profissionais, condições de trabalho e suas implicações na saúde precisam ser adensadas, para que se pensem alternativas coletivas, a fim de assegurar uma atuação crítica e em consonância com as condições éticas, técnicas e laborais.

A pesquisa, além de possibilitar uma aproximação ao cotidiano laboral de assistentes sociais inseridos nos diversos e complexos espaços sócio-ocupacionais, também pode ser um recurso importante para estreitar os vínculos entre a universidade, os espaços de atuação profissional e as entidades representativas da categoria, de forma a dialogar e construir coletivamente ações que garantam um exercício profissional comprometido com as demandas sociais da população, com os direitos dos usuários, com a qualidade dos serviços prestados, com a 
democratização do acesso às políticas sociais e com as devidas condições éticas e técnicas no trabalho de assistentes sociais.

\section{Referências}

ALBUQUERQUE, Guilherme Souza Cavalcanti de; SILVA, Marcelo José de Souza. Sobre a saúde, os determinantes da saúde e a determinação social da saúde. Saúde em Debate, Rio de Janeiro, v. 38, n. 103, p. 953-965, 2014.

BRAVO, Maria Inês Souza. Política de Saúde no Brasil. In: MOTA, Ana Elizabete; BRAVO, Maria Inês Souza (org.). Serviço Social e Saúde: formação e trabalho profissional. São Paulo: Cortez, 2007.

BRAVO, Maria Inês Souza; MATOS, Maurílio Castro de. Projeto ético-político do Serviço Social e sua relação com a Reforma Sanitária: elementos para o debate. In: MOTA, Ana Elizabete; BRAVO, Maria Inês Souza (org.). Serviço Social e Saúde: formação e trabalho profissional. São Paulo: Cortez, 2007.

BRAVO, Maria Inês Souza; PELAEZ, Elaine Junger; PINHEIRO, Wladimir Nunes. As contrarreformas na política de saúde do governo Temer. Revista Argumentum, Vitória, v. 10, n. 1, p. 9-23, jan./abr. 2018. CAMPOS, Gastão Wagner de Sousa; DOMITTI, Ana Carla. Apoio matricial e equipe de referência: uma metodologia para gestão do trabalho interdisciplinar em saúde. Cadernos de Saúde Pública, Rio de Janeiro, v. 23, n. 2, p. 399-407, 2007.

CONSELHO FEDERAL DE SERVIÇO SOCIAL (CFESS). Código de Ética do/a Assistente Social: Lei no 8.662/1993 de regulamentação da profissão. 10. ed. rev. e atual. Brasília: CFESS, 2012.

CONSELHO FEDERAL DE SERVIÇO SOCIAL (CFESS). Parâmetros para a Atuação de Assistentes Sociais na Saúde. Brasília: CFESS, 2010. 
CONSELHO NACIONAL DE SAÚDE (CNS). Resolução nº 218, de 6 de março de 1997. Diário Oficial da União, Brasília, Seção I, p. 893233, 5 maio 1997.

FLEURY-TEIXEIRA, Paulo. Uma introdução conceitual à determinação social da saúde. Saúde em Debate, Rio de Janeiro, v. 33, n. 83, p. 380-389, 2009.

GÖTTEMS, Leila Bernardo Donato. Análise da Política de Atenção Primária à Saúde Desenvolvida no Distrito Federal: a articulação entre o contexto político, os problemas, as alternativas e os atores na formação da política de Saúde (1979 a 2009). 2010. Tese (Doutorado em Administração) - Universidade de Brasília, Brasília, 2010.

GUERRA, Yolanda. A dimensão técnico-operativa do exercício profissional. In: SANTOS, Claudia Monica dos; BACKX, Sheila; GUERRA, Yolanda. A dimensão técnico-operativa no Serviço Social: desafios contemporâneos. Juiz de Fora: UFJF, 2012.

GUERRA, Yolanda. O projeto profissional crítico: estratégia de enfrentamento das condições contemporâneas da prática profissional. Revista Serviço Social e Sociedade, São Paulo, ano 28, n. 91, p. 5-33, 2007. GUIMARÃES, Eliane Martins de Souza. Expressões conservadoras no trabalho em saúde: a abordagem familiar e comunitária em questão. Revista Serviço Social e Sociedade, São Paulo, Cortez, n. 130, p. 564-582, 2017.

IAMAMOTO, Marilda V. Os espaços sócio-ocupacionais do assistente social. In: CONSELHO FEDERAL DE SERVIÇO SOCIAL; ASSOCIAÇÃO BRASILEIRA DE ENSINO E PESQUISA EM SERVIÇO SOCIAL. Serviço Social: direitos sociais e competências profissionais. Brasília: CFESS/ABEPSS, 2009, p. 341-375.

IAMAMOTO, Marilda V. Serviço social em tempo de capital fetiche: capital financeiro, trabalho e questão social. São Paulo: Cortez, 2008. 
LAVRAS, Carmen. Atenção Primária à Saúde e a Organização de Redes Regionais de Atenção à Saúde no Brasil. Revista Saúde e Sociedade, São Paulo, v. 20, n. 4, p. 867-874, 2011.

MATOS, Maurílio Castro de. Assistente Social: trabalhador(a) da área da saúde. Reflexões a partir do debate brasileiro. Revista Interaç̧ões, Santarém, Portugal, n. 17, p. 45-63, 2009.

MATOS, Maurílio Castro de. Considerações sobre atribuições e competências profissionais de assistentes sociais na atualidade. Revista Serviço Social e Sociedade, São Paulo, n. 124, p. 678-698, 2015.

MINAYO, Maria Cecília de Souza. O desafio do conhecimento: pesquisa qualitativa em saúde. 12. ed. São Paulo: Hucitec, 2010.

MOTA, Ana Elizabete. Espaços ocupacionais e dimensões políticas da prática do assistente social. Revista Serviço Social e Sociedade, São Paulo, n. 120, p. 694-705, 2014.

NETTO, José Paulo. A construção do projeto ético-político do Serviço Social. In: MOTA, Ana Elizabete; BRAVO, Maria Inês Souza (org.). Serviço Social e Saúde: formação e trabalho profissional. São Paulo: Cortez, 2007.

NETTO, José Paulo. Ditadura e Serviço Social: uma análise do Serviço Social no Brasil pós-64. 5. ed. São Paulo: Cortez, 2001.

RAICHELIS, Raquel. O assistente social como trabalhador assalariado: desafios frente às violações de seus direitos. Serviço Social e Sociedade, São Paulo, n. 107, p. 420-437, jul./set. 2011.

SANTOS, Claudia Monica. Na prática a teoria é outra? Mitos e dilemas na relação entre teoria, prática, instrumentos e técnicas no Serviço Social. Rio de Janeiro: Lumen Juris, 2010.

TRINDADE, Rosa Lúcia Prédes. Ações profissionais, procedimentos e instrumentos no trabalho dos assistentes sociais nas políticas sociais. In: SANTOS, Claudia Monica dos; BACKX, Sheila; GUERRA, Yolanda (org.). A dimensão técnico-operativa no Serviço Social: desafios contemporâneos. Juiz de Fora: UFJF, 2012. 


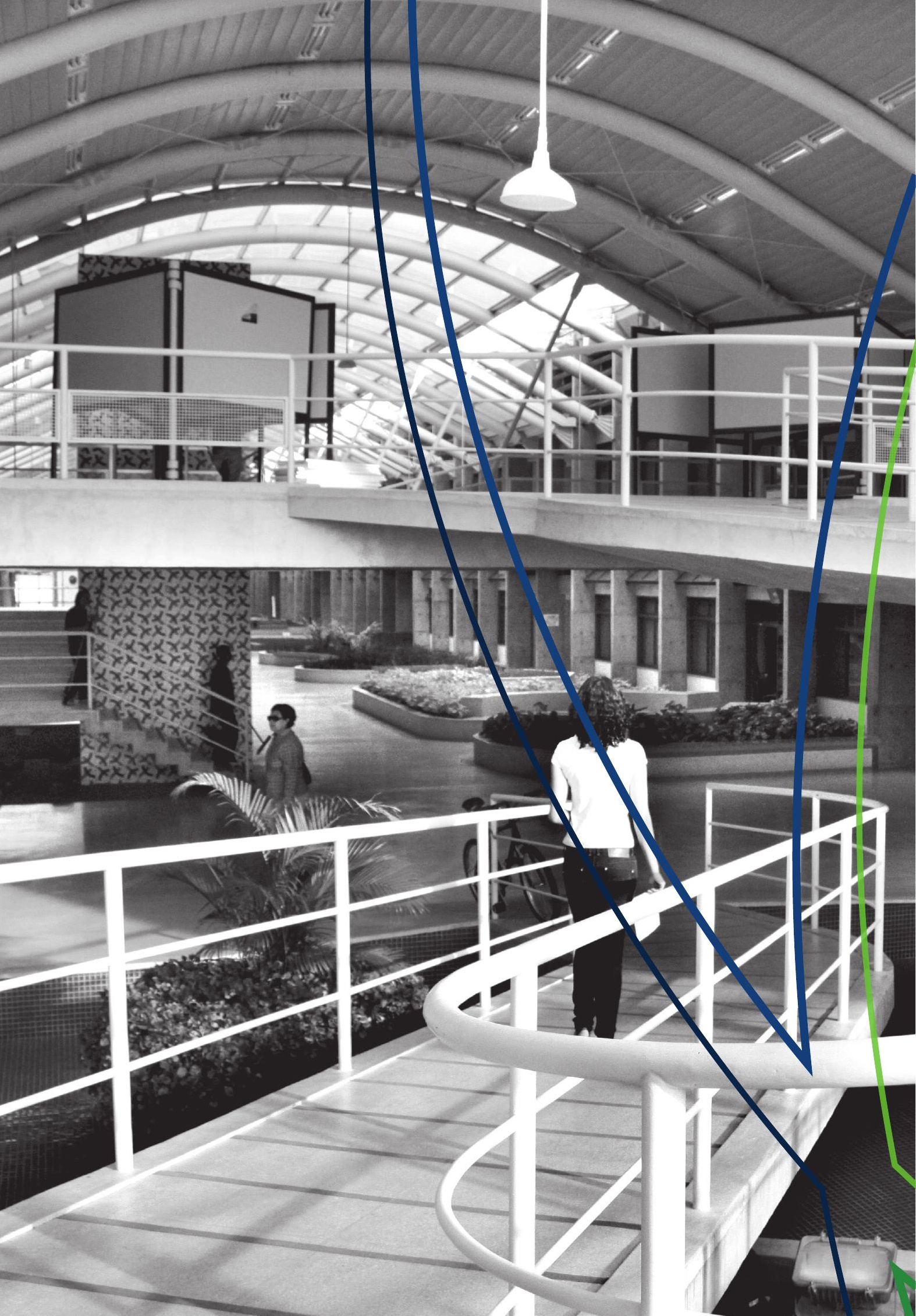




\section{Sobre os autores e as autoras}

\section{Andreia de Oliveira}

Docente do Departamento de Serviço Social e do Programa de Pós-Graduação em Política Social da Universidade de Brasília (UnB). Possui graduação em Serviço Social, mestrado em Saúde Púbica pela Universidade Federal de Santa Catarina (UFSC) e doutorado em Serviço Social pela Pontifícia Universidade Católica de São Paulo (PUC-SP). Pesquisadora e membro do Grupo de Estudos e Pesquisas sobre Trabalho, Sociabilidade e Serviço Social (Trasso).

\section{Eduardo Augusto Rodrigues Barros}

Possui graduação em Serviço Social e mestrado em Política Social pela Universidade de Brasília (UnB). É assistente social da carreira pública socioeducativa do Distrito Federal. Pesquisador e membro do Grupo de Estudos e Pesquisas sobre Trabalho, Sociabilidade e Serviço Social (Trasso). 


\section{Michelly Ferreira Monteiro Elias}

Docente do Departamento de Serviço Social da Universidade de Brasília (UnB). Possui graduação em Serviço Social pela Universidade Estadual Paulista “Júlio de Mesquita Filho” (Unesp), mestrado em Políticas Públicas pela Universidade Federal do Maranhão (UFMA) e doutorado em Serviço Social pela Universidade Federal do Rio de Janeiro (UFRJ). Pesquisadora e membro do Grupo de Estudos e Pesquisas sobre Trabalho, Sociabilidade e Serviço Social (Trasso).

\section{Natália Pereira Caixeta}

Possui graduação em Serviço Social e mestrado em Política Social pela Universidade de Brasília (UnB). Atua como assistente social na área da educação no Distrito Federal. Pesquisadora e membro do Grupo de Estudos e Pesquisas sobre Trabalho, Sociabilidade e Serviço Social (Trasso).

\section{Regiane Cota e Rocha}

Possui graduação em Pedagogia pela Universidade Federal de Minas Gerais (UFMG) e mestrado em Política Social pela Universidade de Brasília (UnB). É doutoranda em Política Social pela Universidade de Brasília (UnB). Servidora pública lotada na Secretaria de Desenvolvimento Social (Sedes) do Distrito Federal. Pesquisadora e membro do Grupo de Estudos e Pesquisas sobre Trabalho, Sociabilidade e Serviço Social (Trasso).

\section{Reginaldo Ghiraldelli}

Docente do Departamento de Serviço Social e do Programa de Pós-Graduação em Política Social da Universidade de Brasília (UnB). Possui graduação, mestrado e doutorado em Serviço Social pela Universidade Estadual Paulista “Júlio de Mesquita Filho” (Unesp). Realizou estágio de pós-doutorado na Università degli Studi di Roma “La Sapienza” (Itália). Coordena o Grupo de Estudos e Pesquisas sobre Trabalho, Sociabilidade e Serviço Social (Trasso). 


\section{Renata Maria da Conceição Freitas}

Possui graduação em Serviço Social e mestrado em Política Social pela Universidade de Brasília (UnB). É assistente social do município de Várzea Grande (MT), lotada no Centro de Referência Especializado de Assistência Social (Creas). Pesquisadora e membro do Grupo de Estudos e Pesquisas sobre Trabalho, Sociabilidade e Serviço Social (Trasso). 
Este livro foi composto em UnB Pro e Liberation Serif. 


\section{Trabalho, direitos e desigualdades na realidade brasileira}

A coletânea organizada por Reginaldo Ghiraldelli reúne capítulos que são resultado de pesquisas de integrantes do Trasso (Grupo de Estudos e Pesquisas sobre Trabalho, Sociabilidade e Serviço Social). Abrange temas importantes, como as questões relacionadas ao trabalho e aos direitos sociais, especialmente neste momento histórico, caracterizado por um clima de obscurantismo e de subtração do compromisso do Estado com o sistema de proteção social.

Os capítulos abordam diferentes aspectos da realidade, com destaque para a situação do mundo do trabalho e a realização dos direitos sociais. Dentre os temas estudados, analisam-se a configuração do trabalho no contexto de reformas, o sindicalismo, a problemática do trabalho temporário, a participação social na política de saúde do trabalhador, a necessária efetivação de uma política de educação permanente para trabalhadores da assistência social, as expressões do trabalho precário na assistência social, as condições de trabalho e as intervenções profissionais de assistentes sociais na área da saúde.

Trata-se de uma obra cuidadosa, que explora diversas questões com olhar crítico e abordagem científica, voltada para pesquisadores e profissionais da área, mas também para todos aqueles que desejam ter uma visão aprofundada dos problemas atuais, em contraste com os slogans superficiais e mistificadores da realidade contemporânea.

\section{Annamaria Campanini}

Docente da Universidade de Milão Bicocca e Presidente da Associação Internacional de Escolas de Serviço Social (IASSW)

Foto ao fundo:

Interior do Instituto de Química/UnB. Por Luiz Felipe Barcelos.
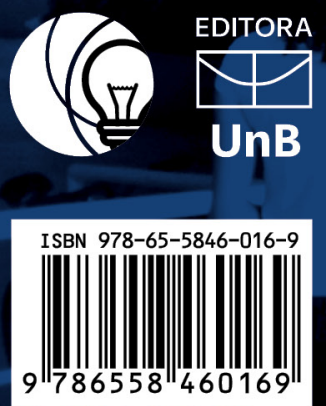